

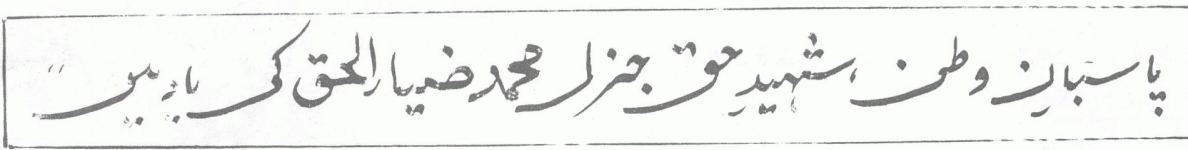

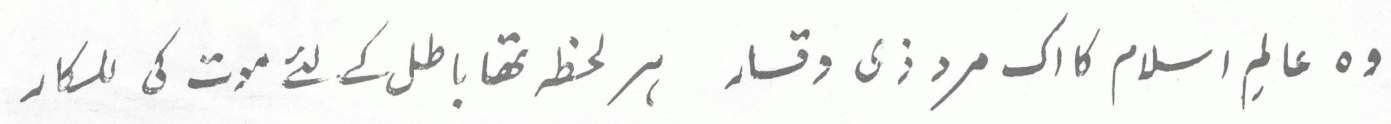

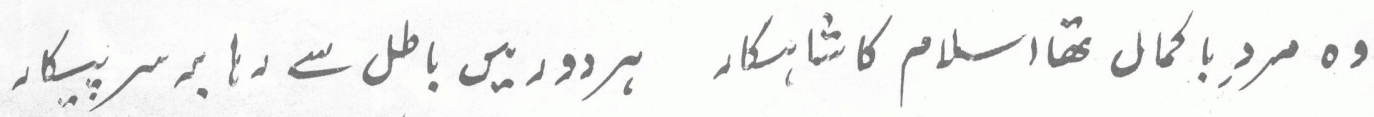

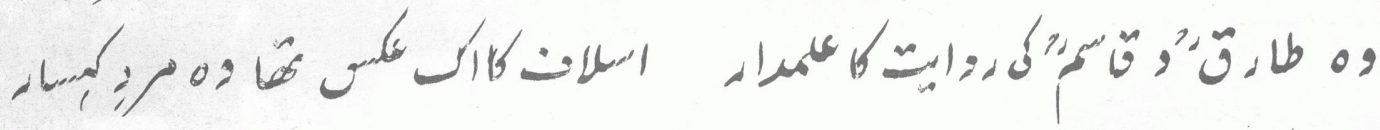

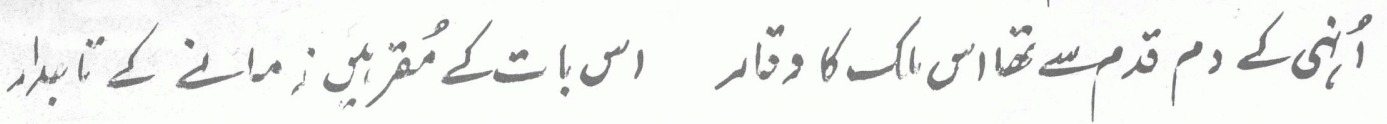

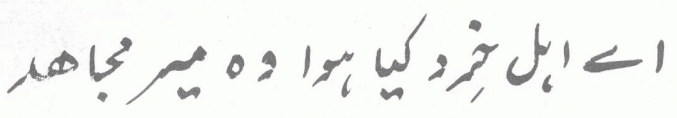

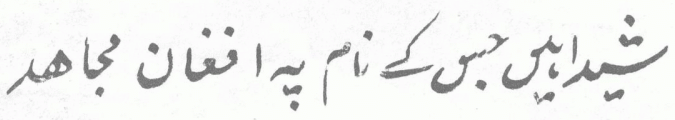

وه

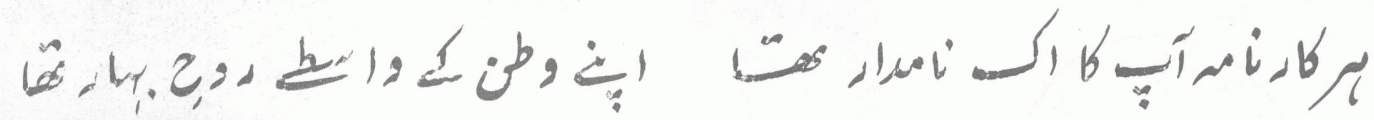

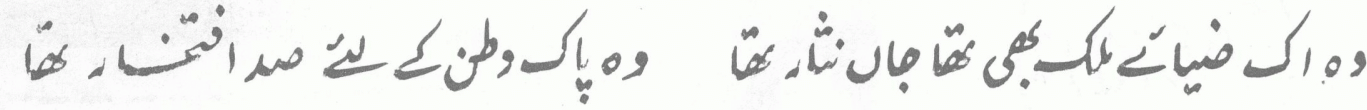

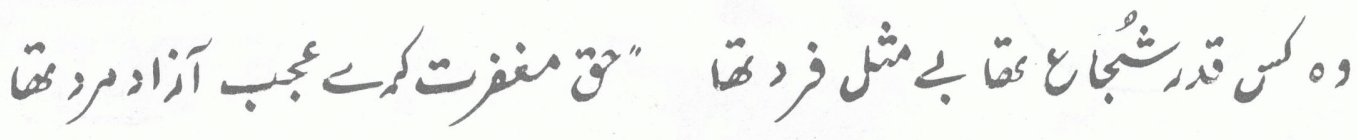

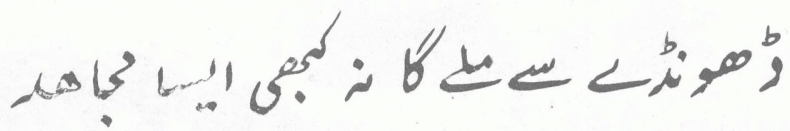

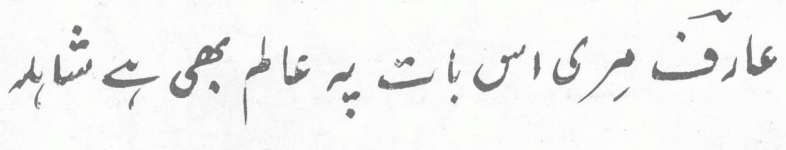

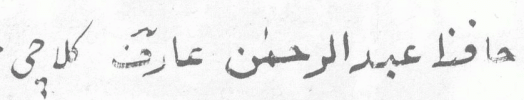

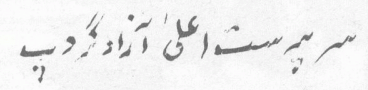


en

N

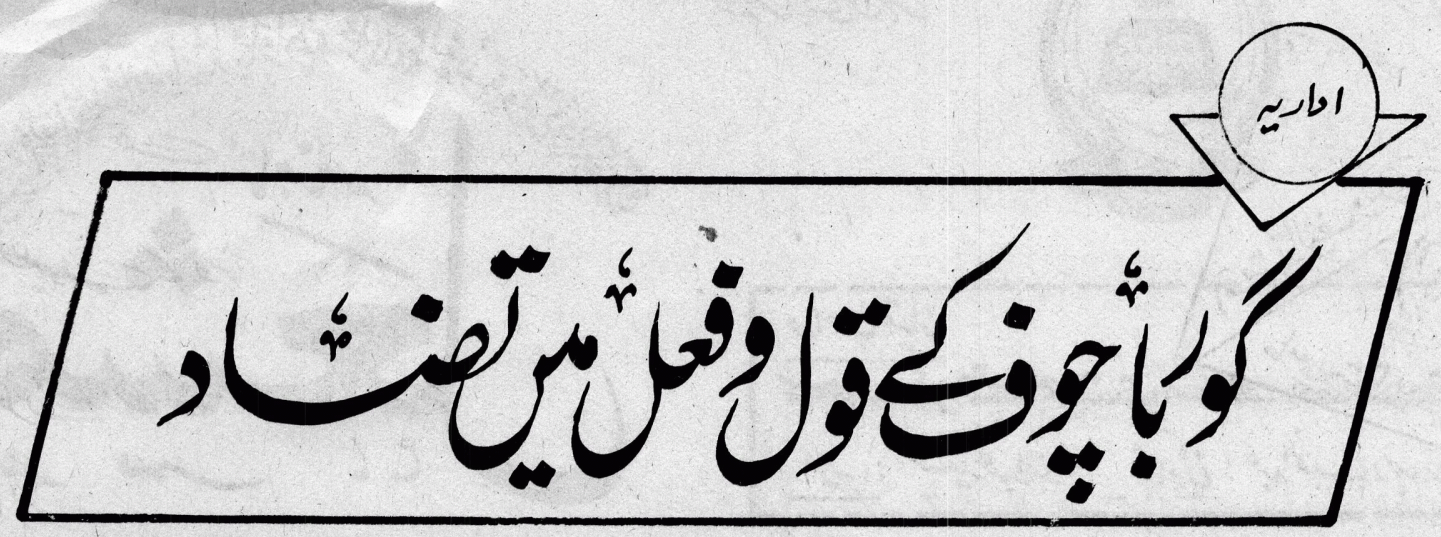

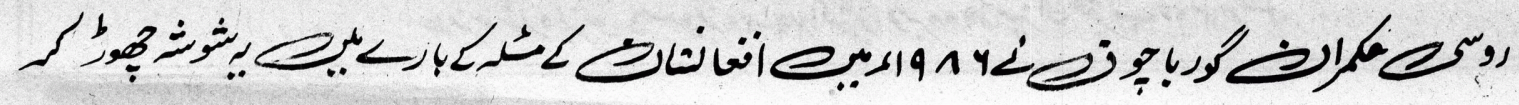

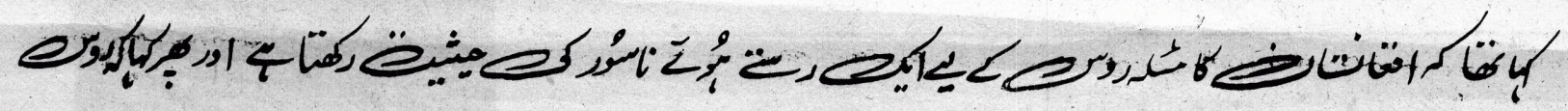

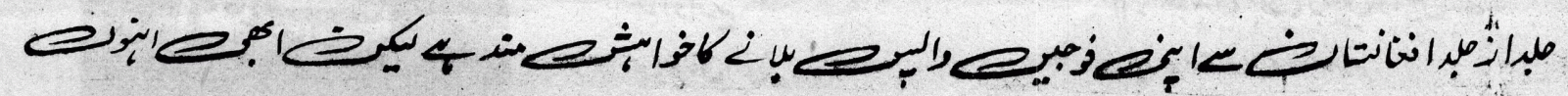

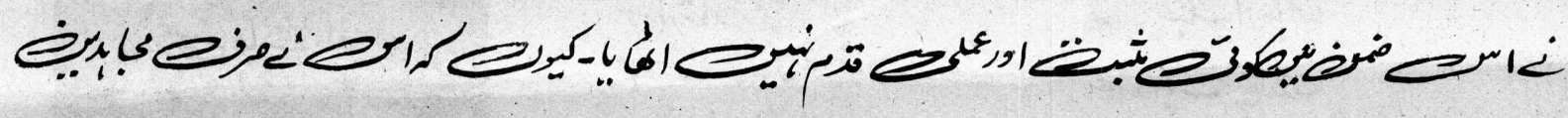

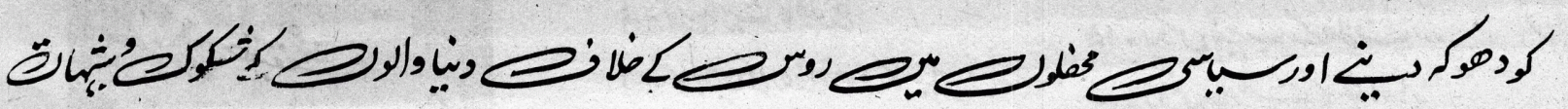

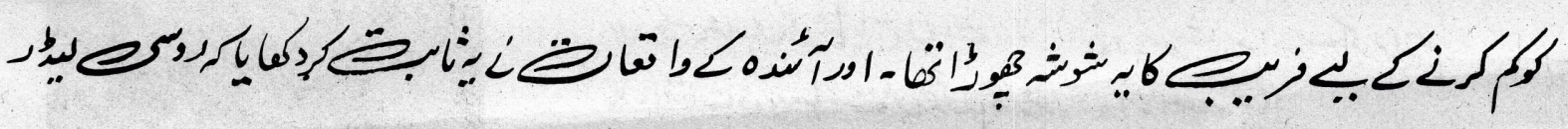

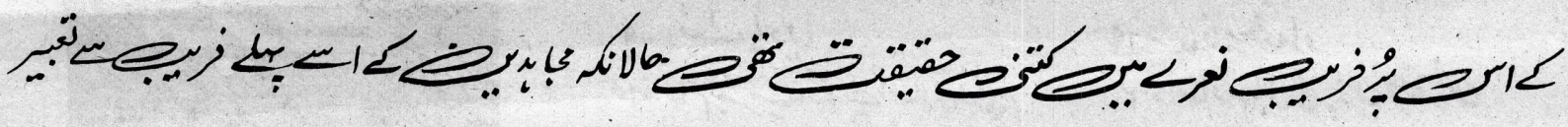

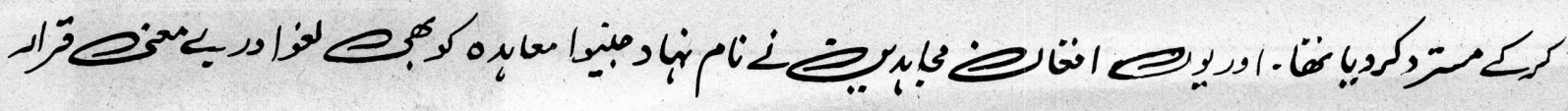

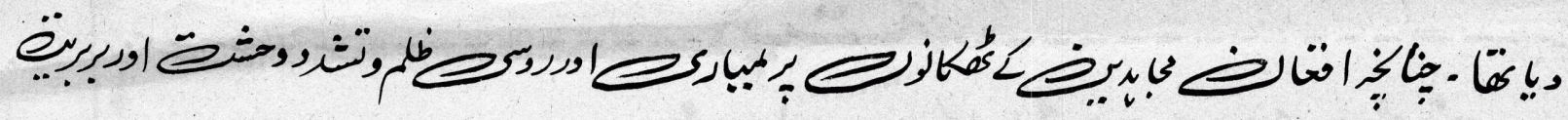
كمبه

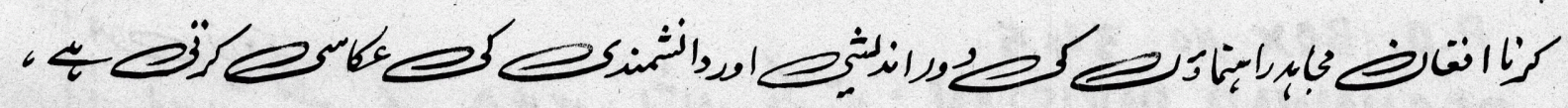

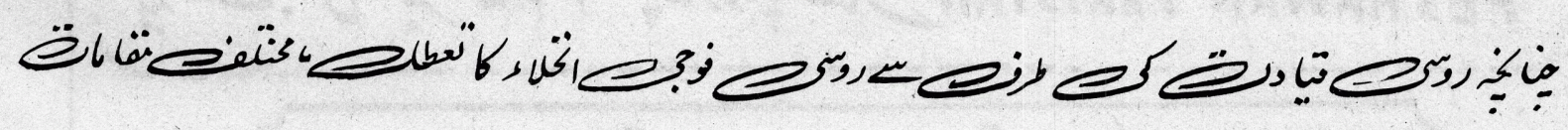

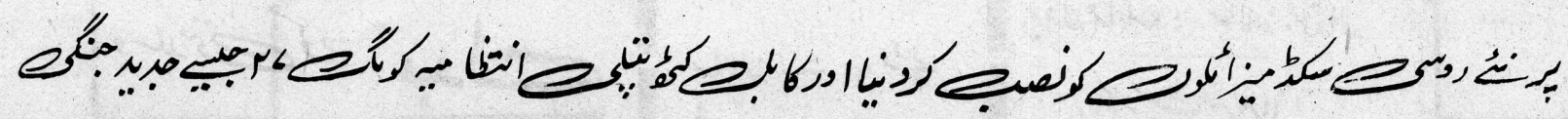

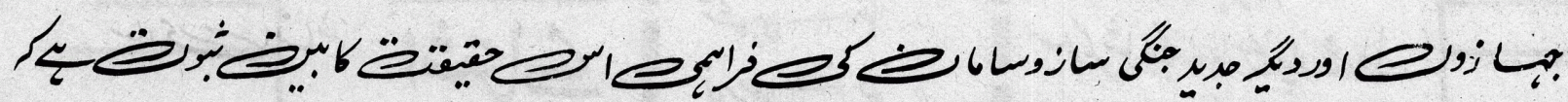


exi

كبرة

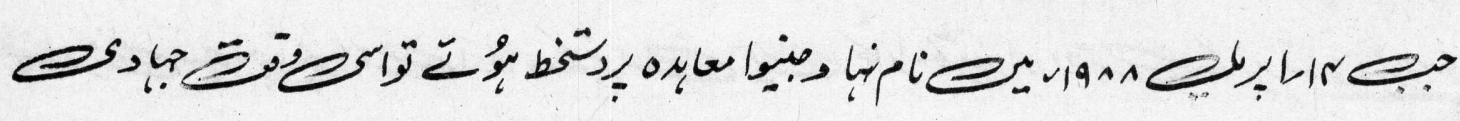

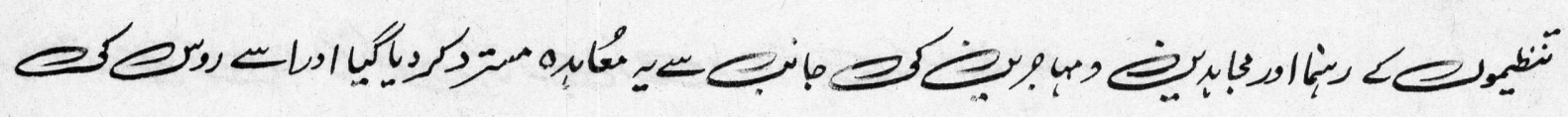

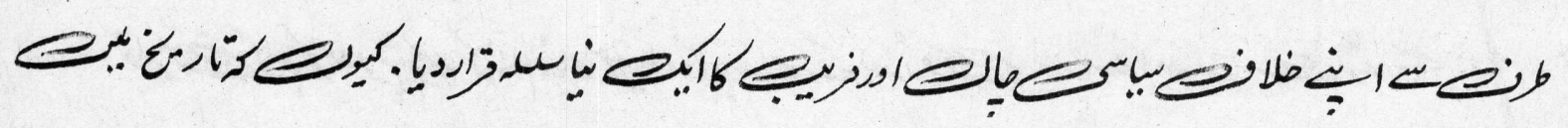

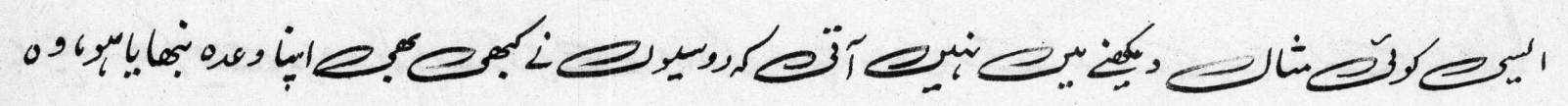

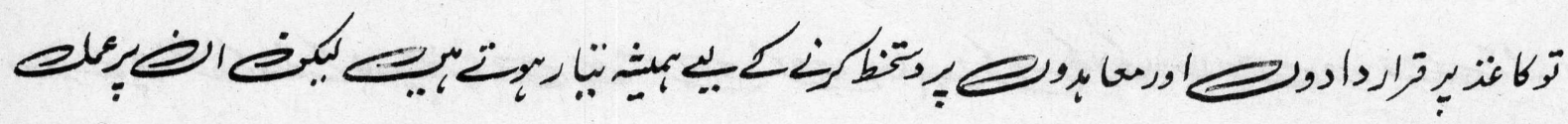

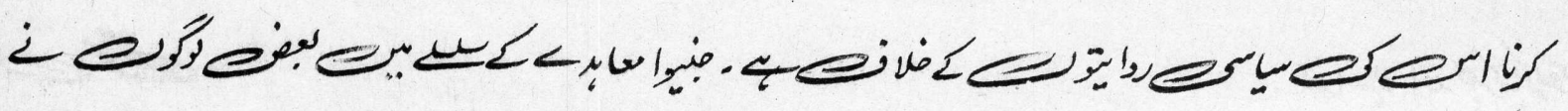

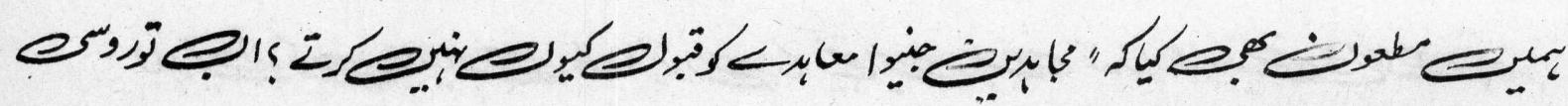

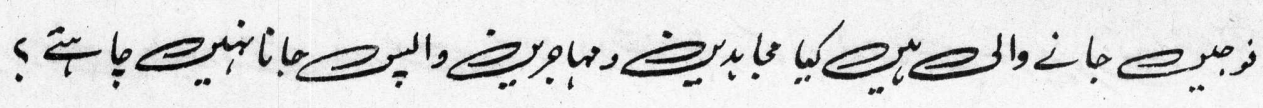

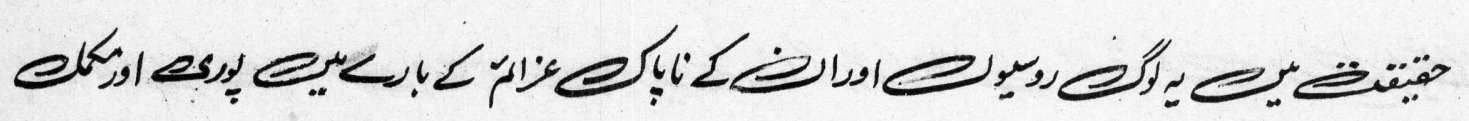

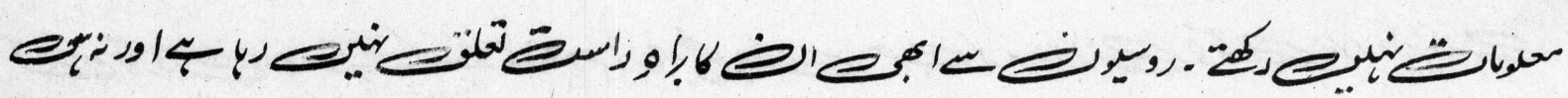

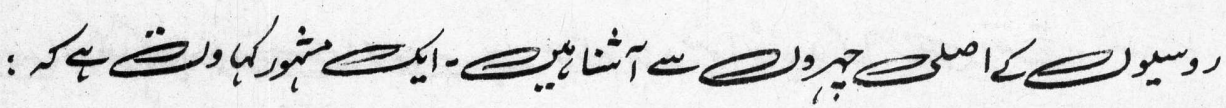

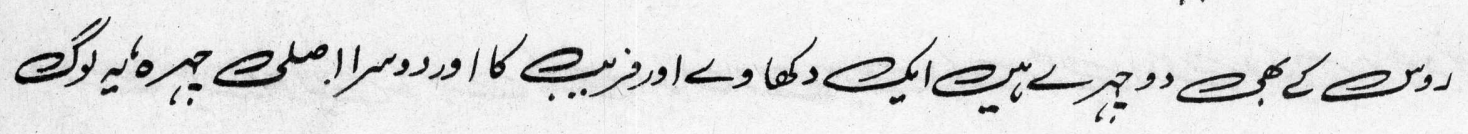

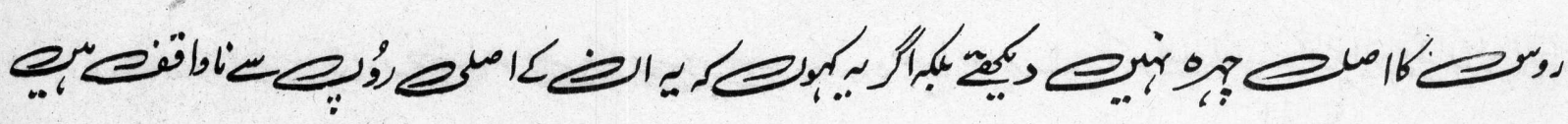

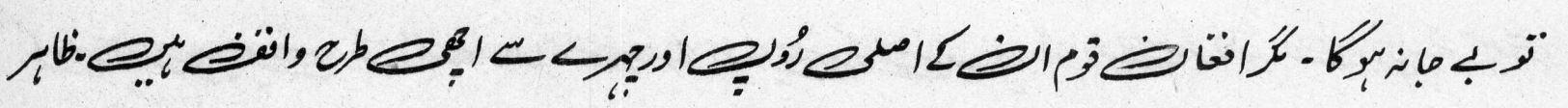

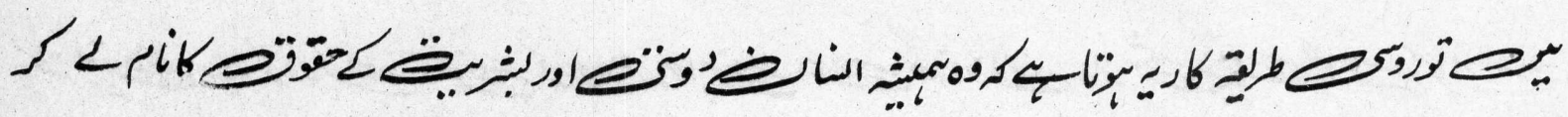

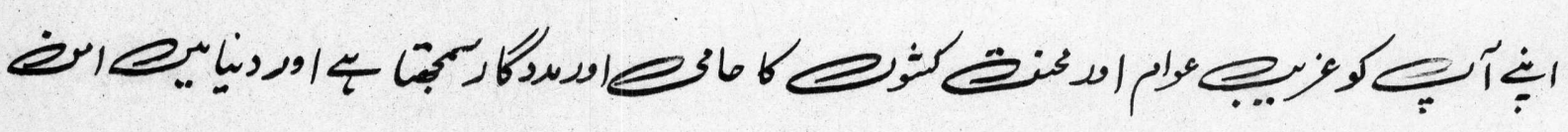

س

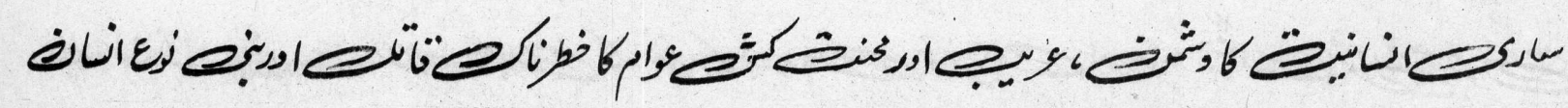




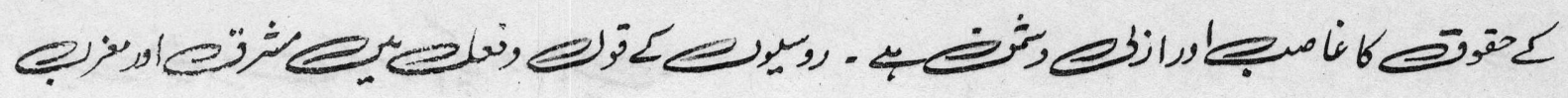

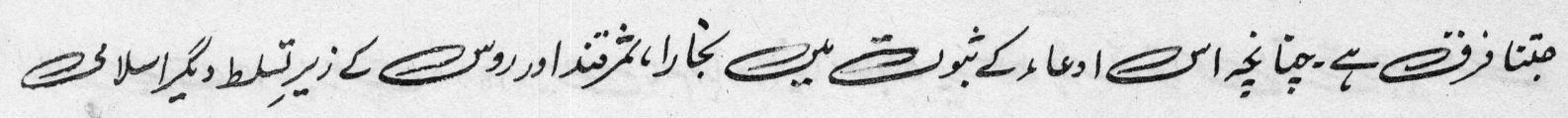

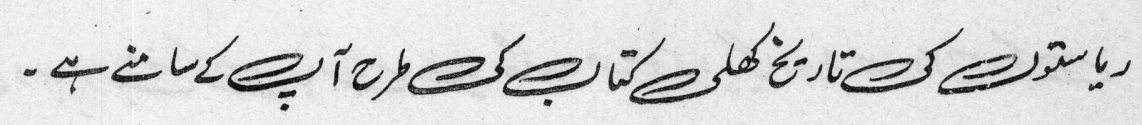

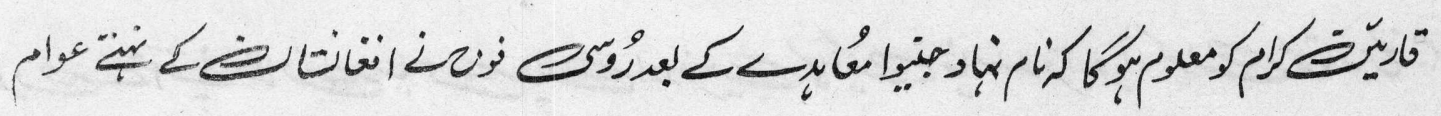

بـ

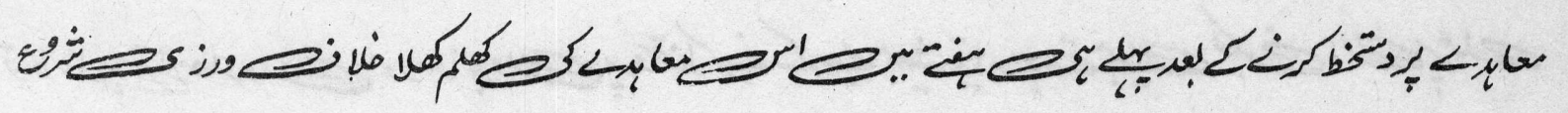
.05

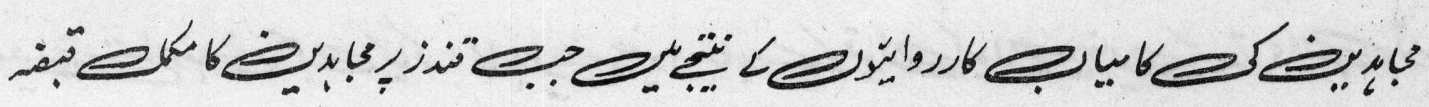

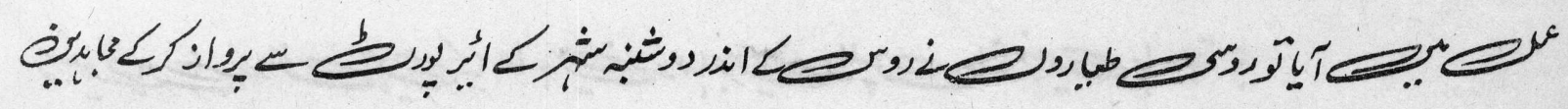

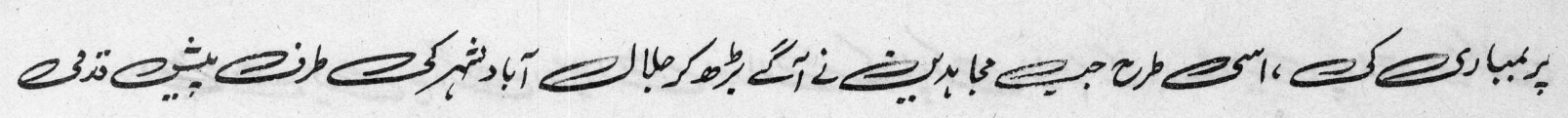
$\Longleftarrow$

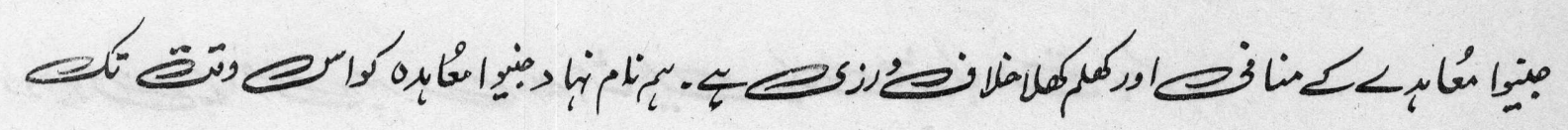
" 定定

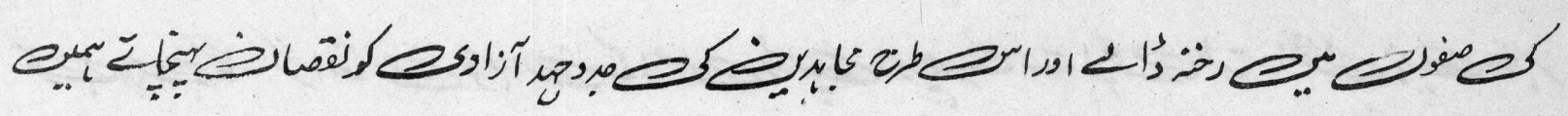
$-6 \div 3,1$

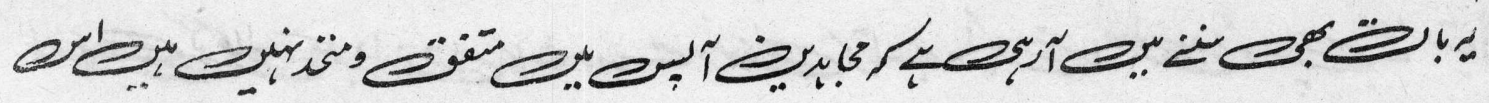

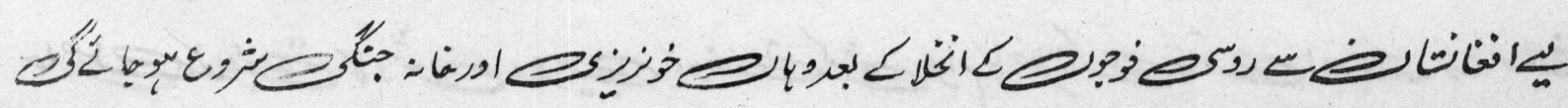


cos

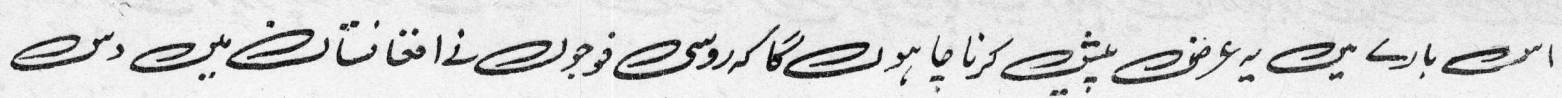

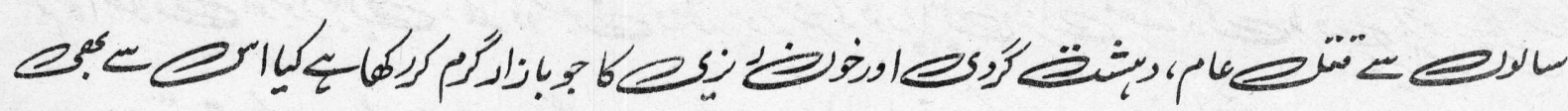

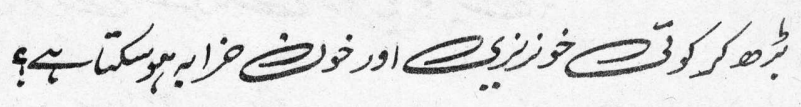

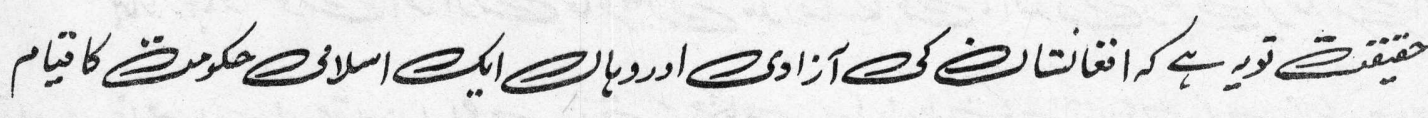

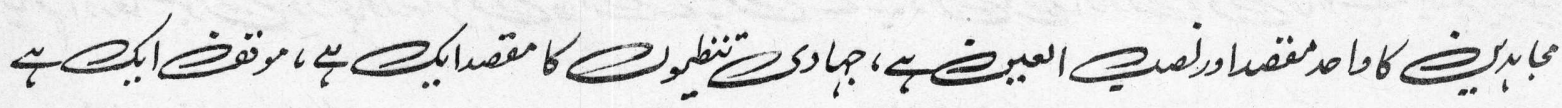

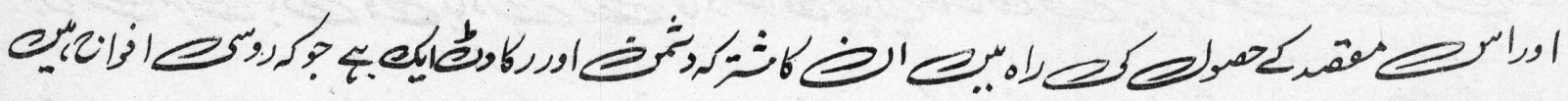

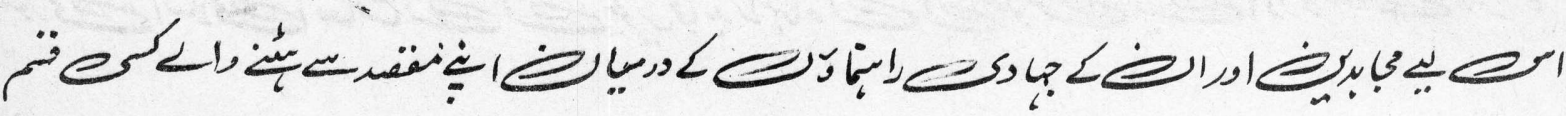

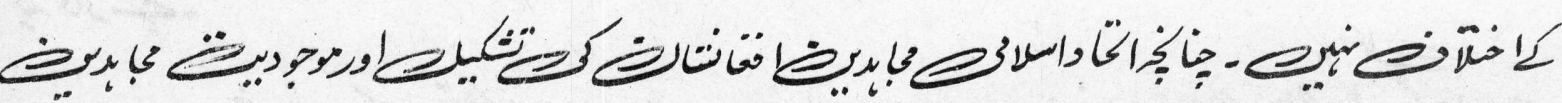
r

- - برن

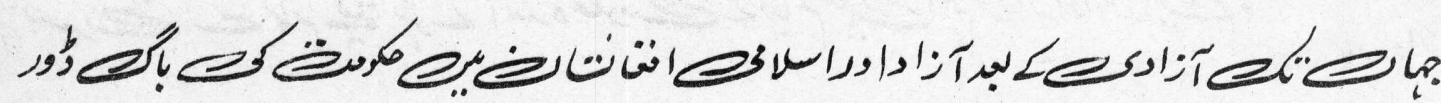

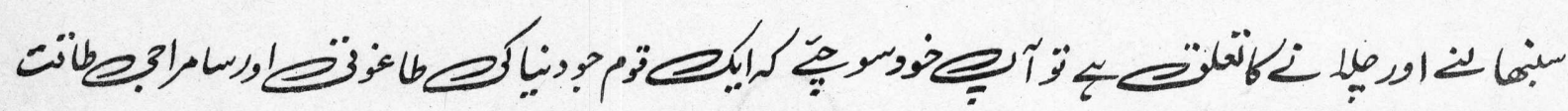

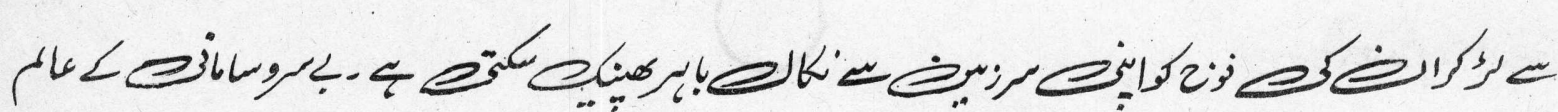

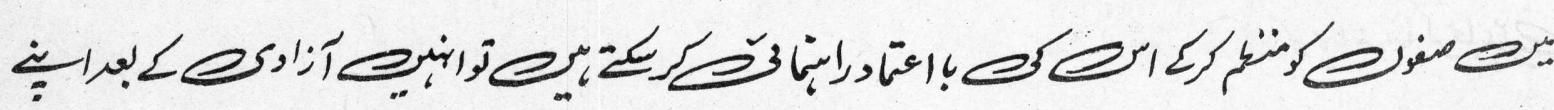

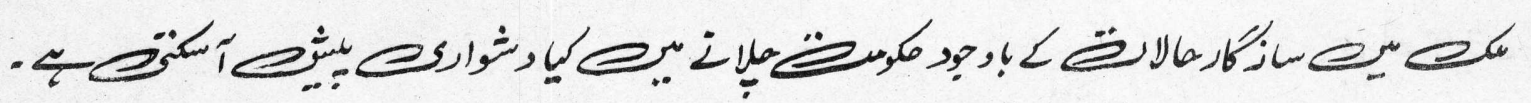

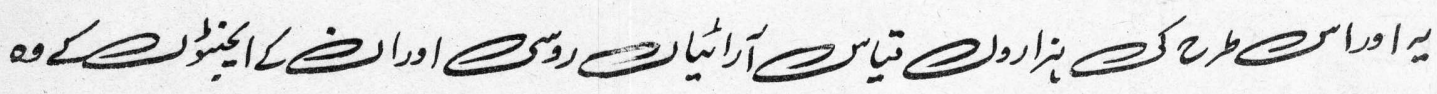

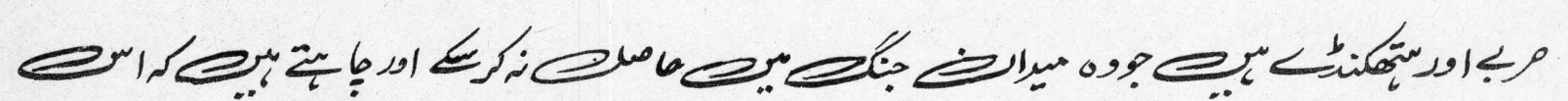

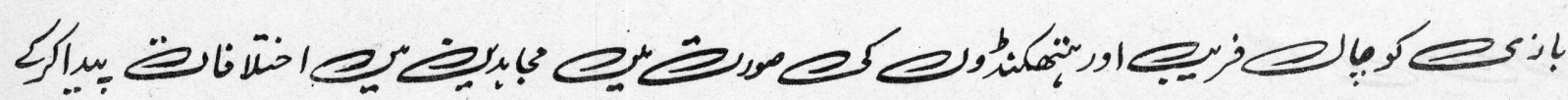

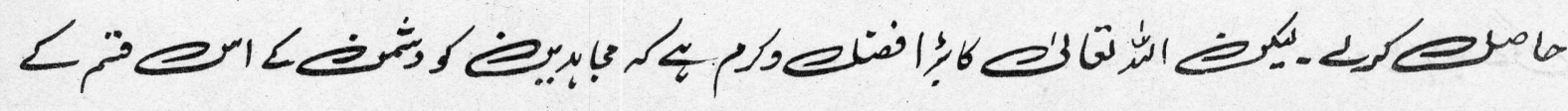


zü

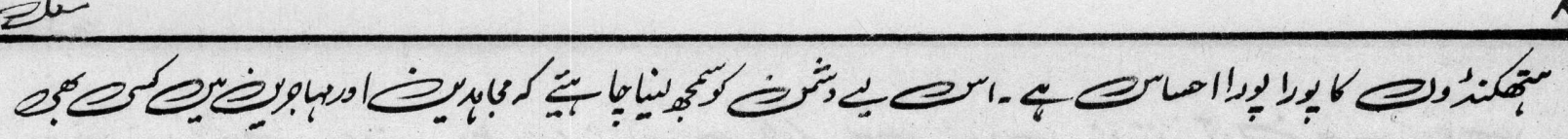

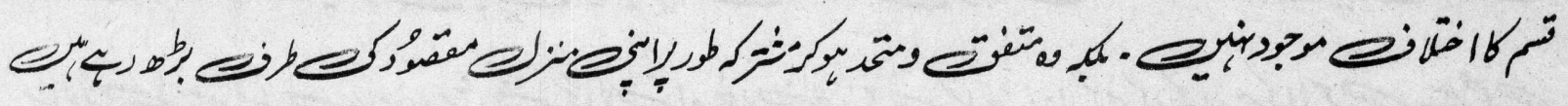

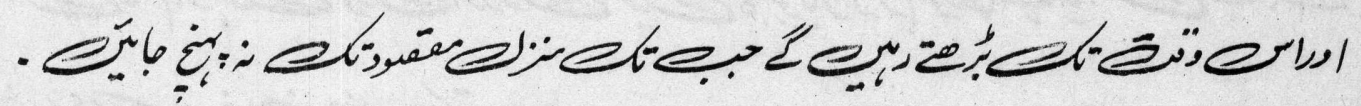

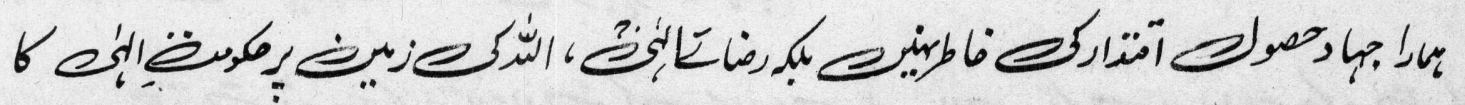

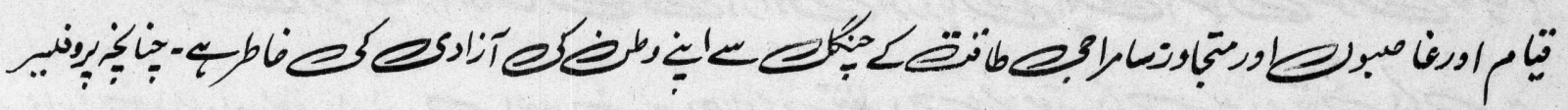

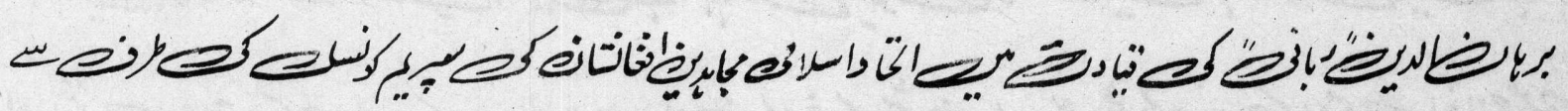

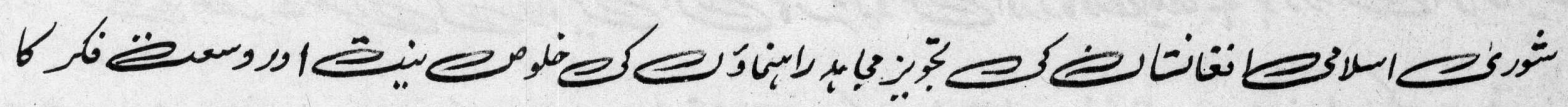

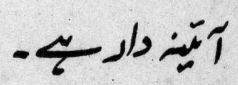

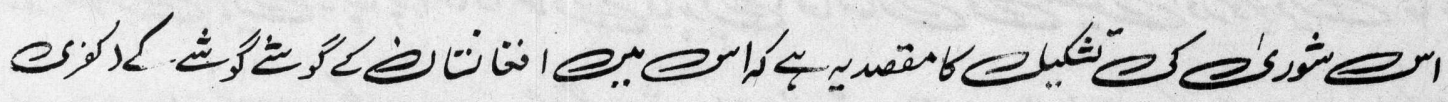

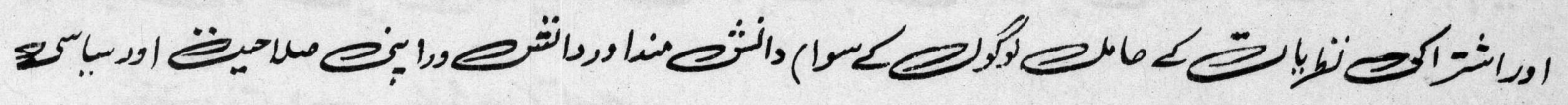

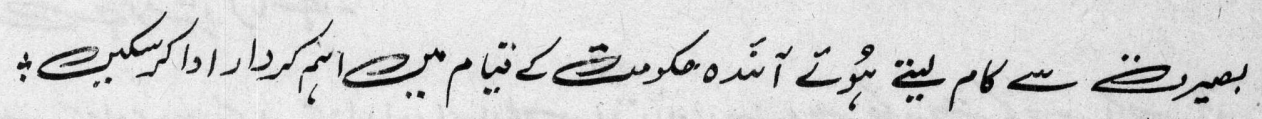



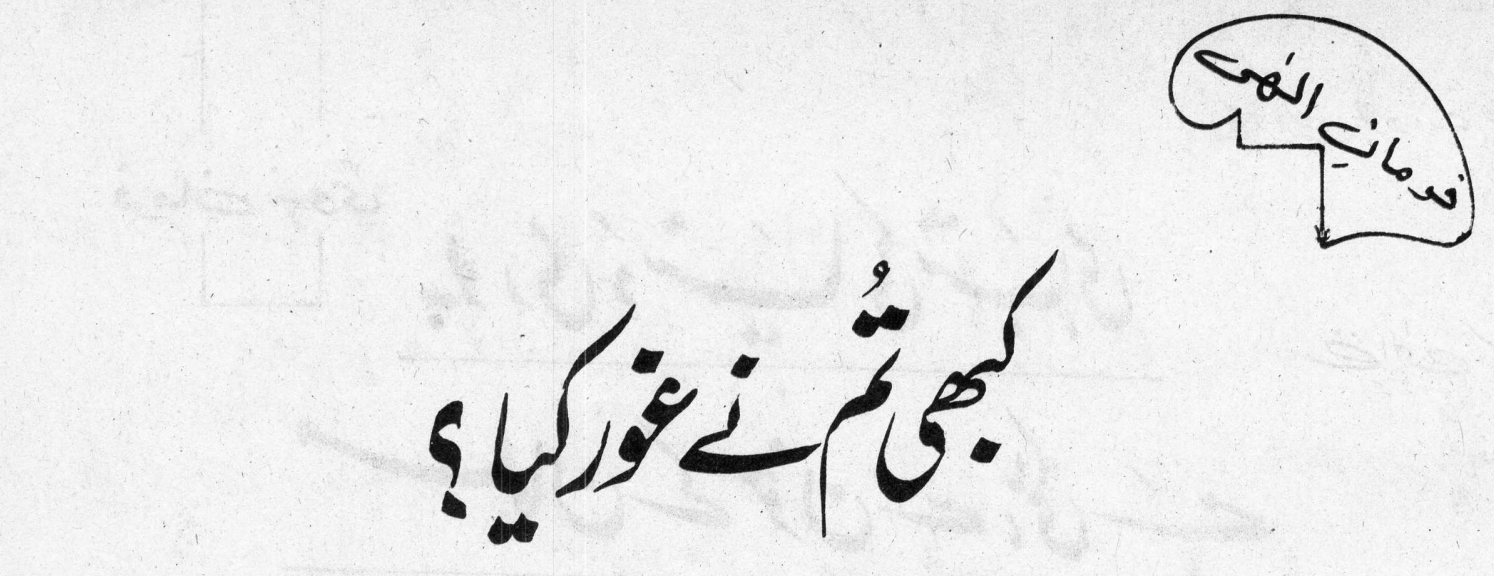

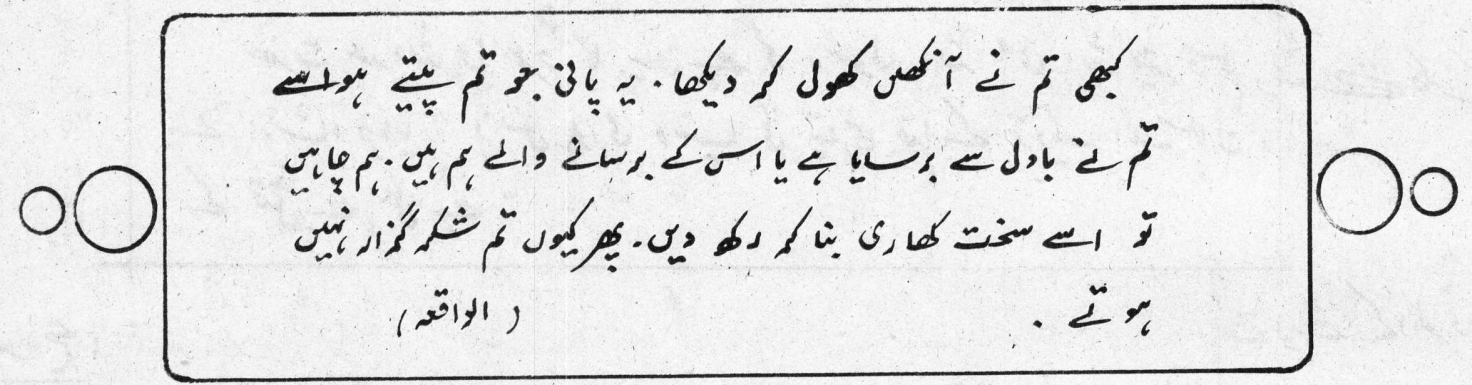

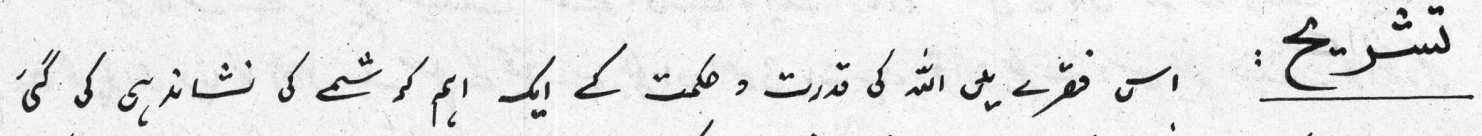

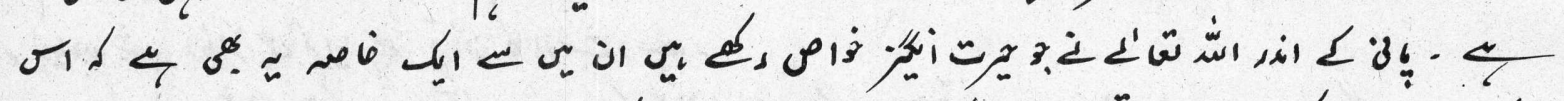
أ

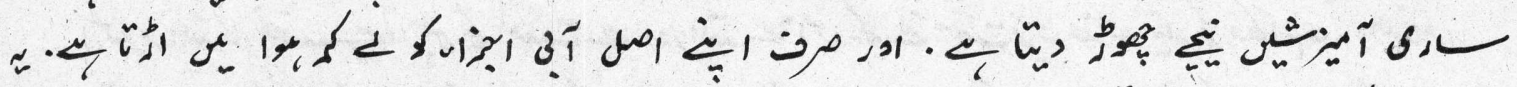

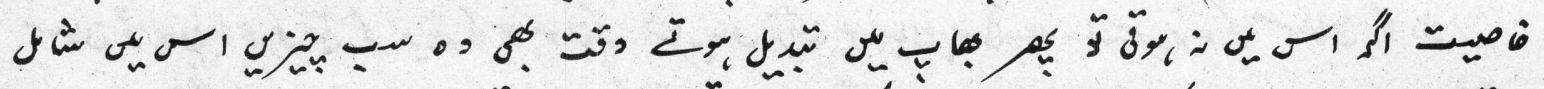
年 f ए إ

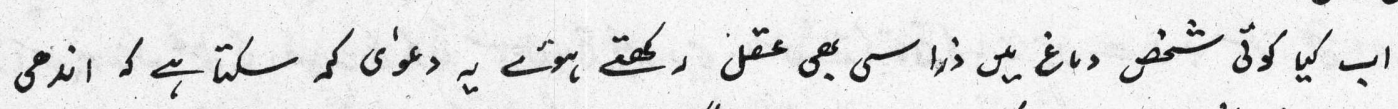

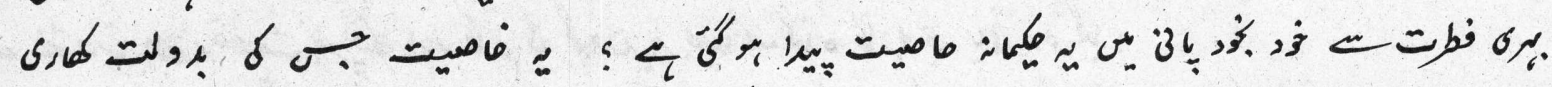

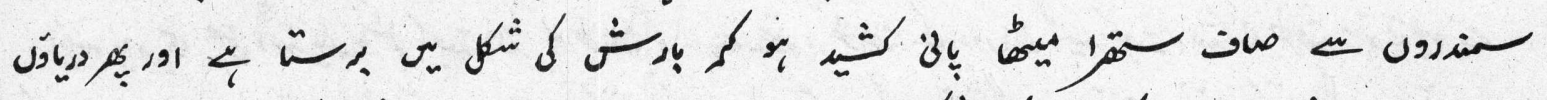

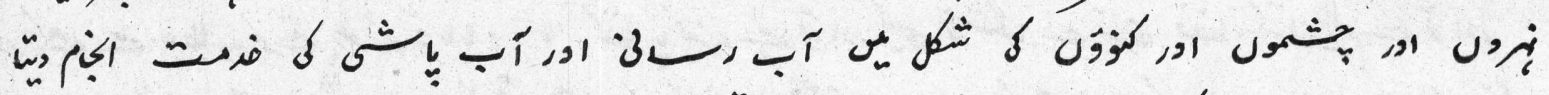

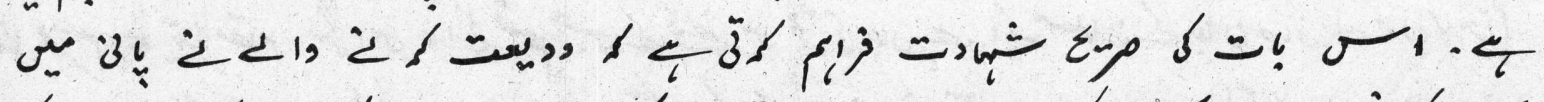
ك J

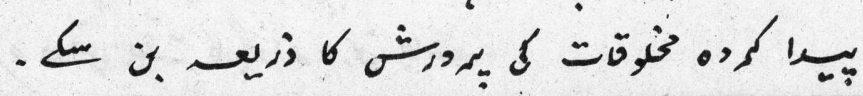




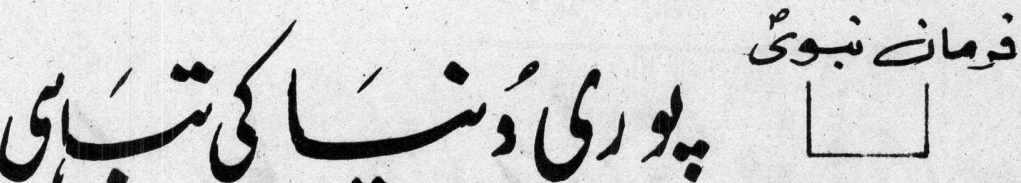

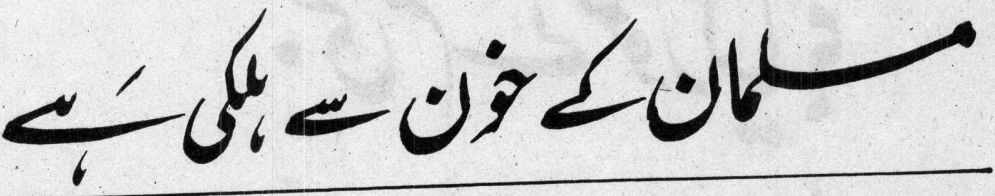

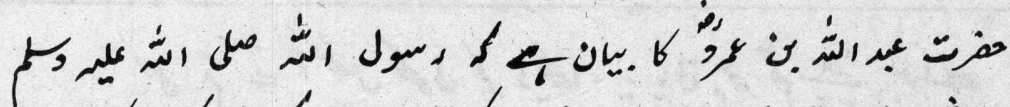

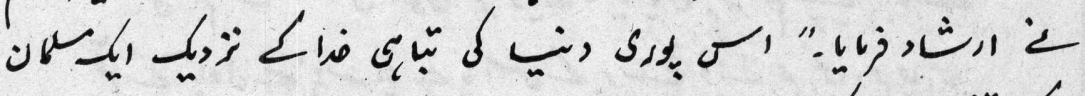

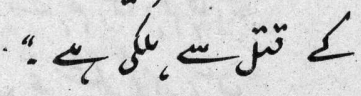

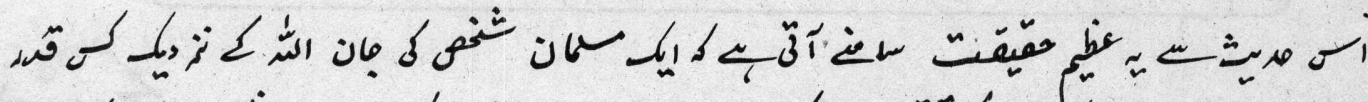

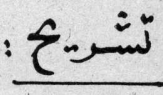

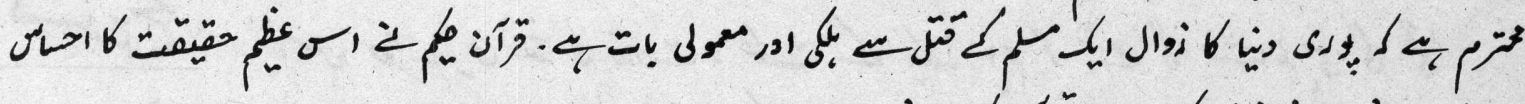
-

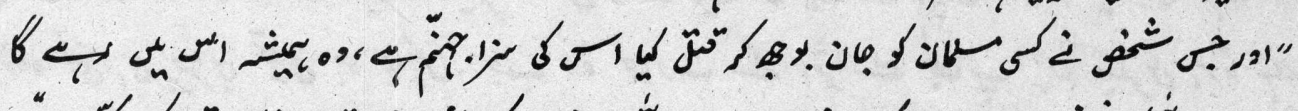

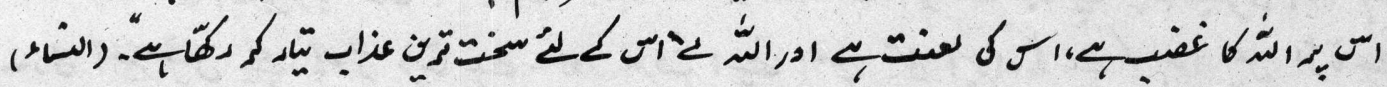

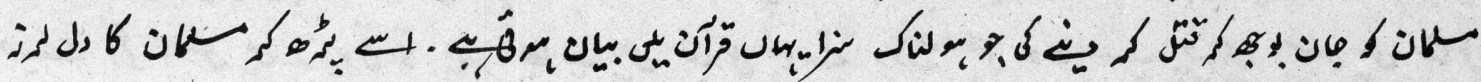

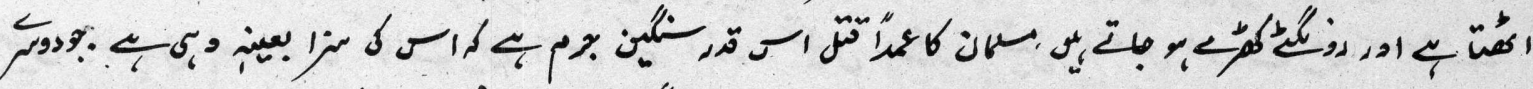

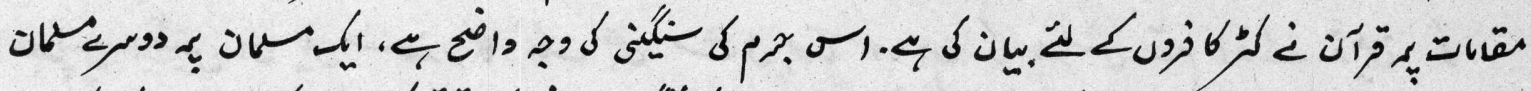

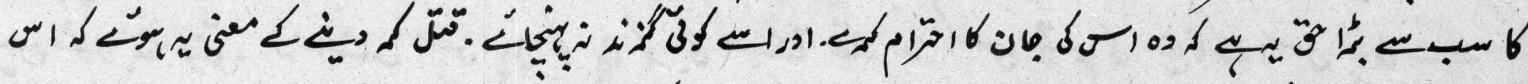

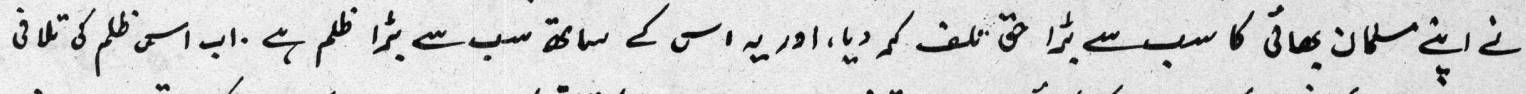

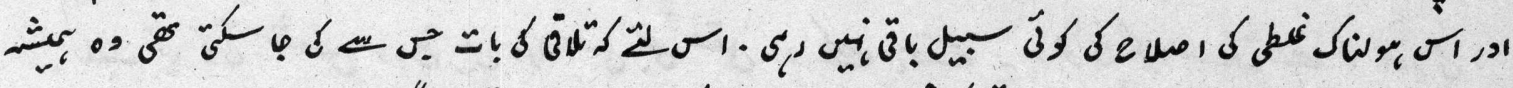

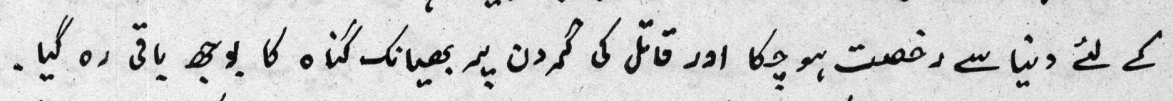

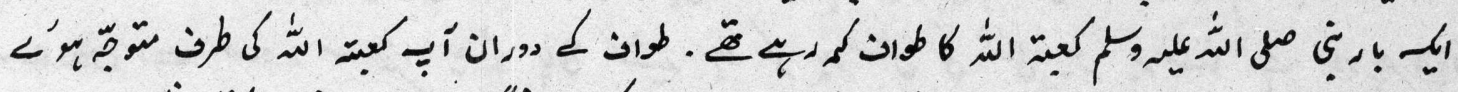

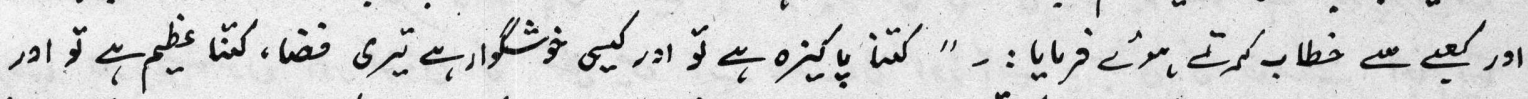

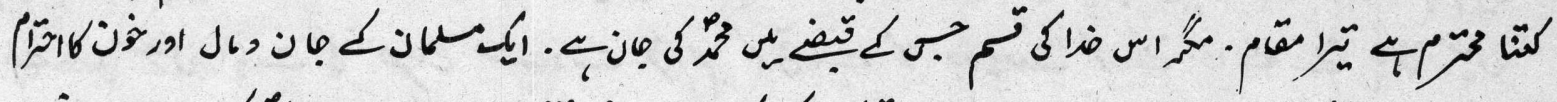

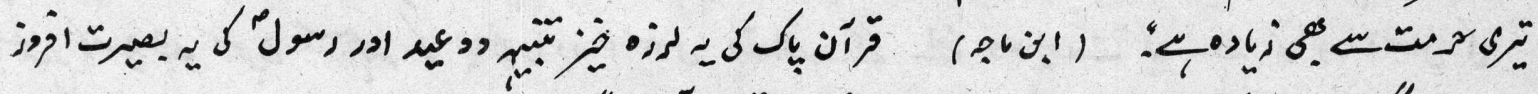
. 
II

ثت

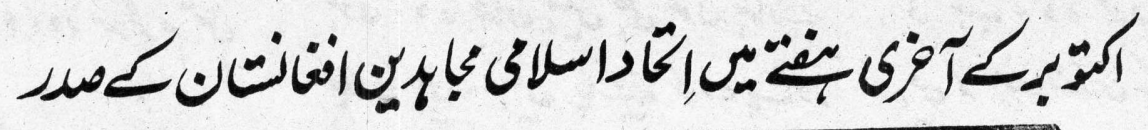

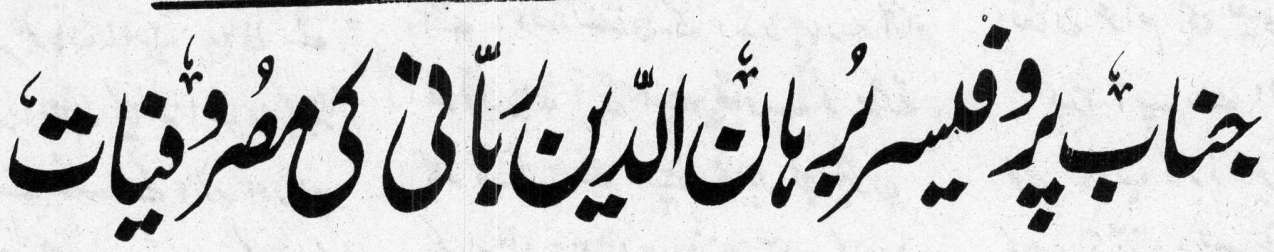

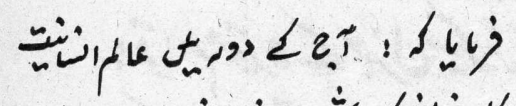

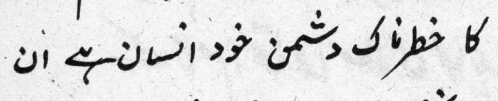

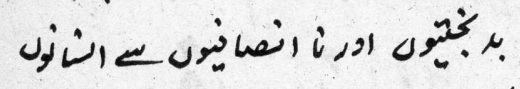
لا द $=1809191.4$ i

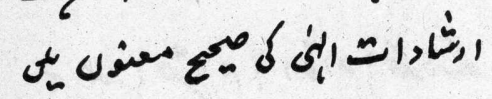
ن ب ه

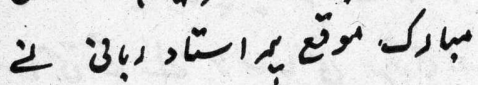

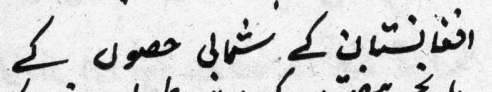

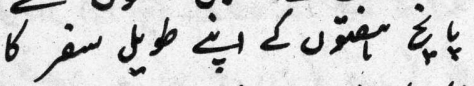

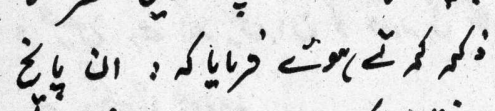

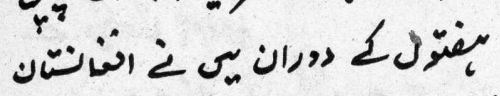

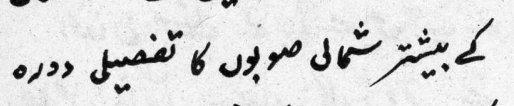
茴 اهر

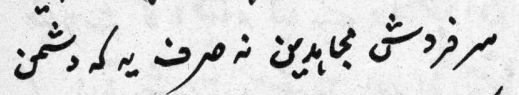

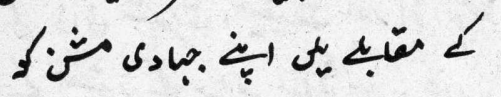

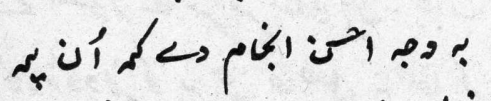

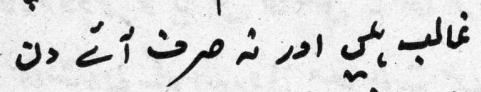

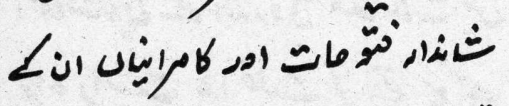

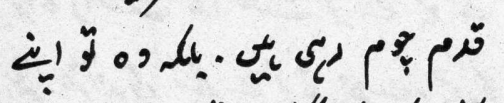

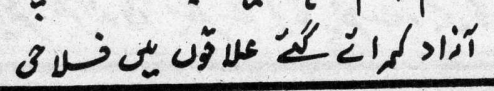

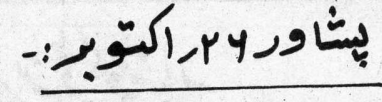

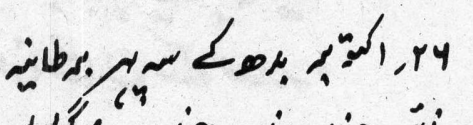

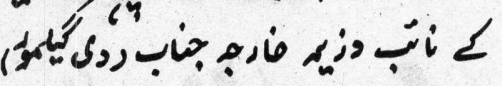

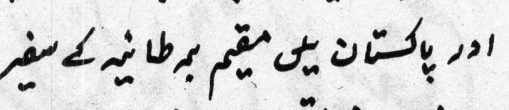

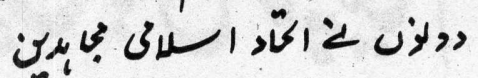

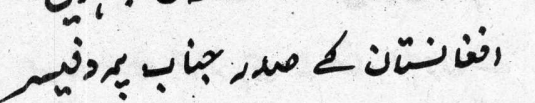

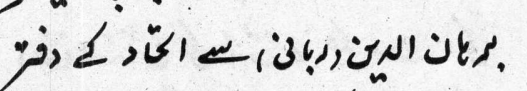

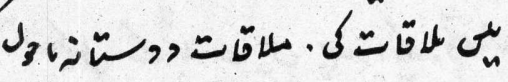

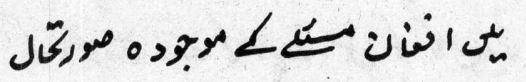

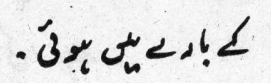

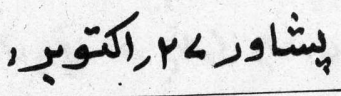
حمت دمول اكمم صلى الضّ

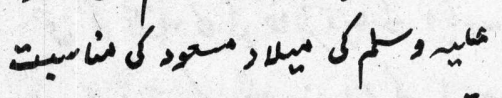

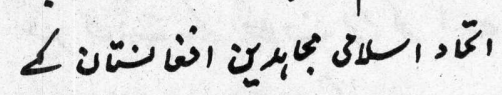

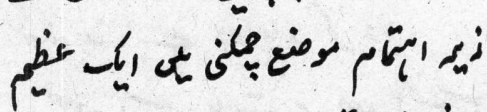

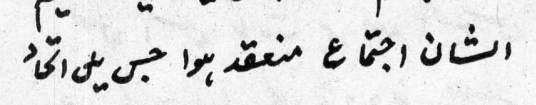

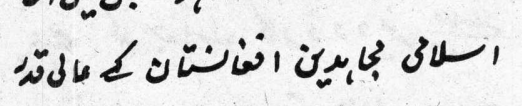

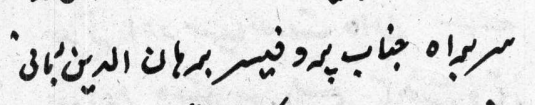
20

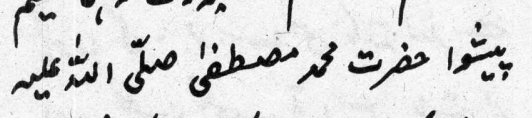

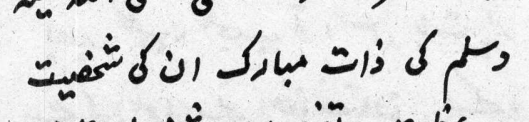

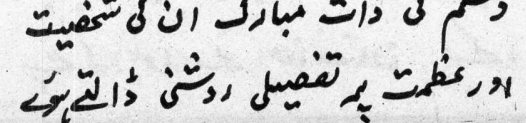

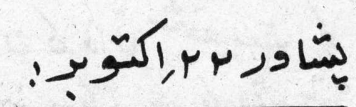

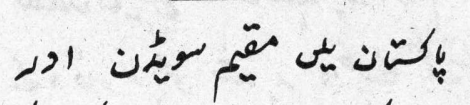
:

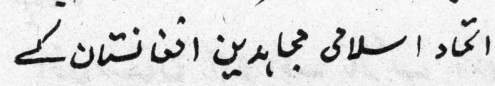

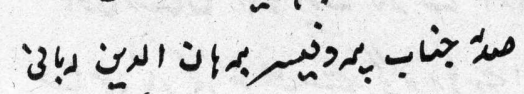

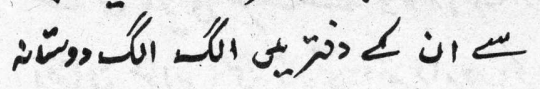

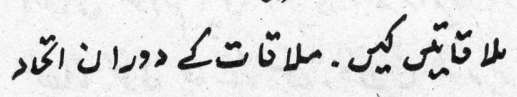

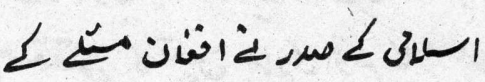

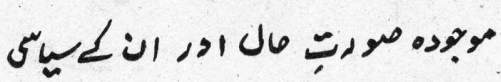

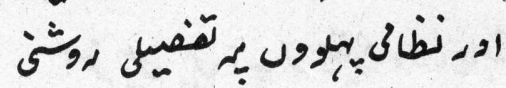
年

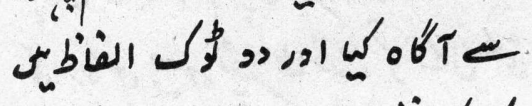

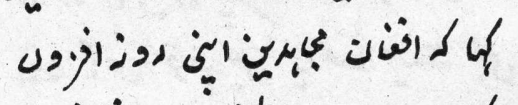

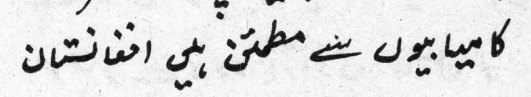

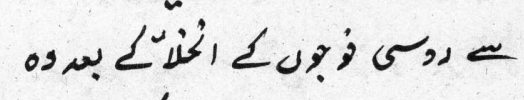

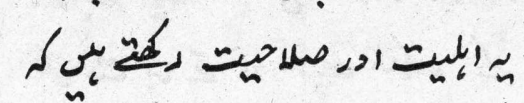
كان

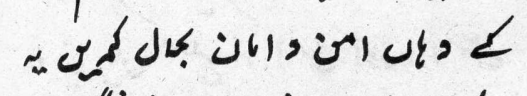

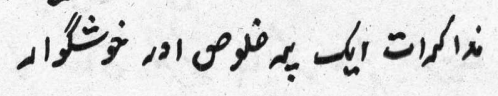

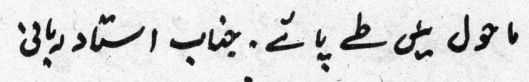

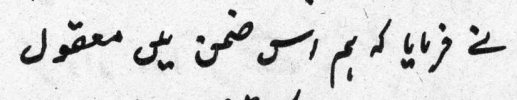

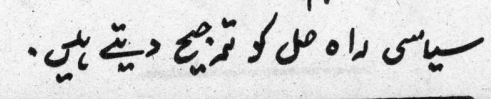


تِق

IN

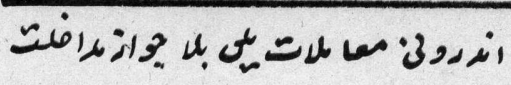

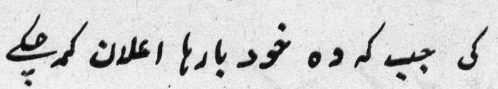

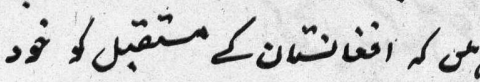

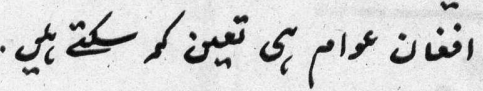

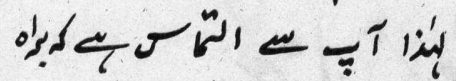

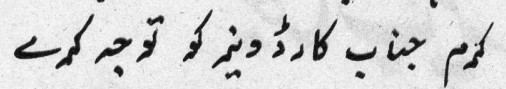

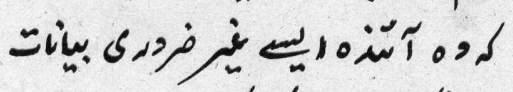

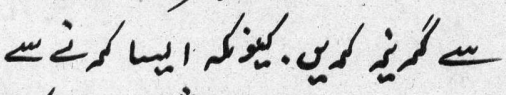

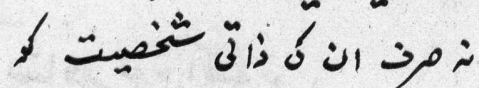

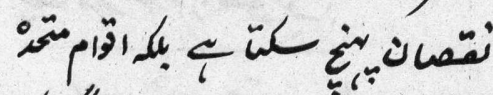

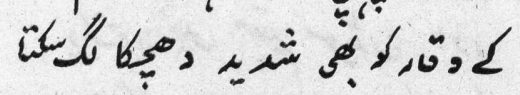

ضان

افे

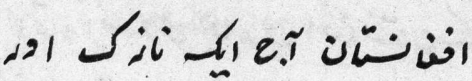

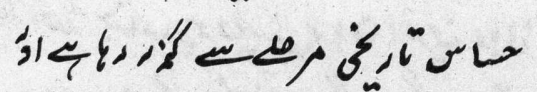

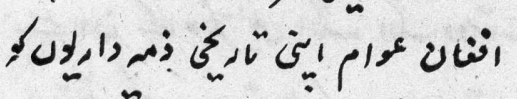

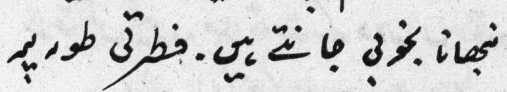

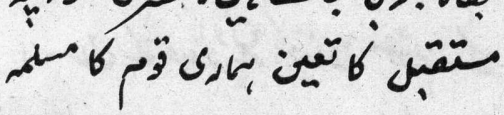
- 40

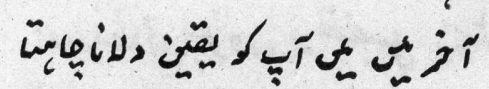

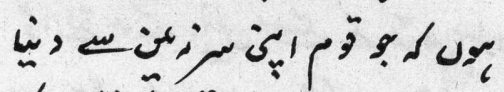

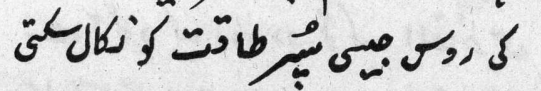

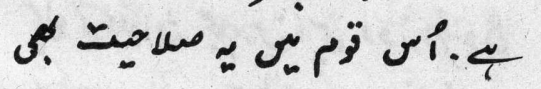
م

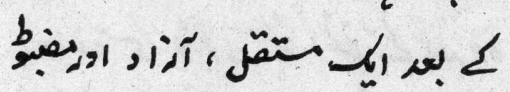
ملون

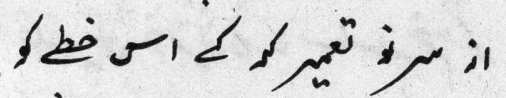

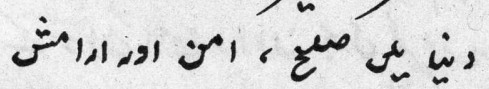

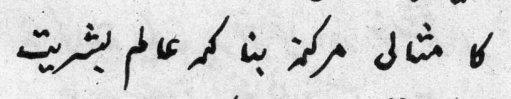

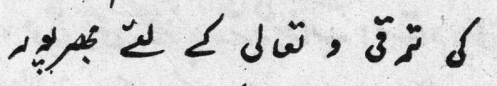
- كم

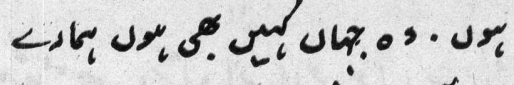

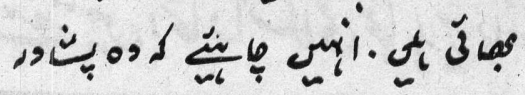

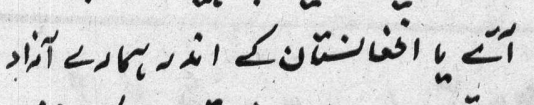

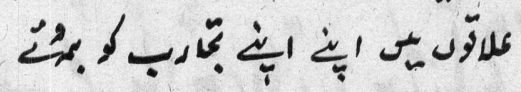

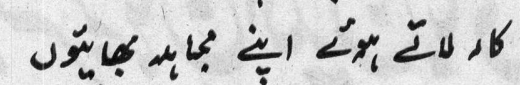

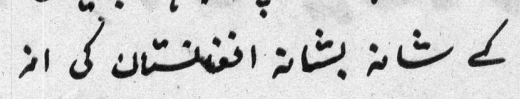

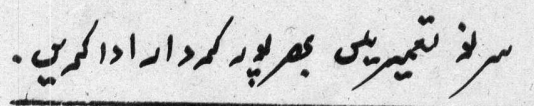

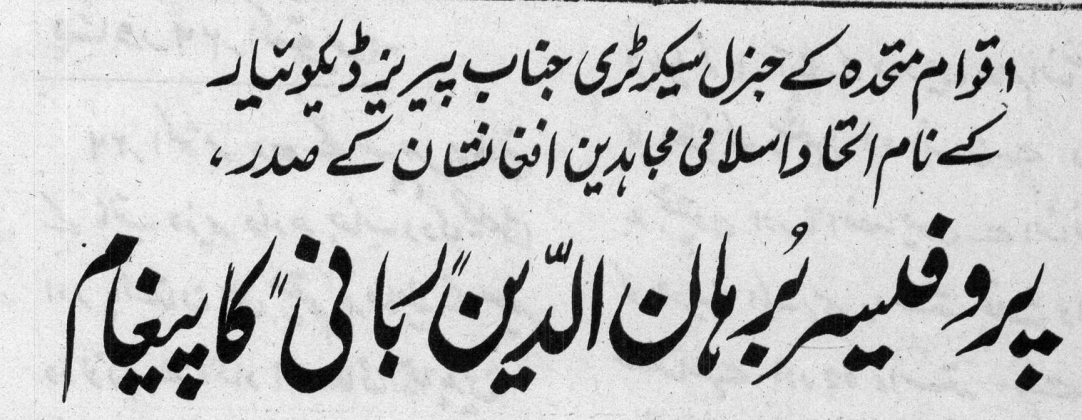

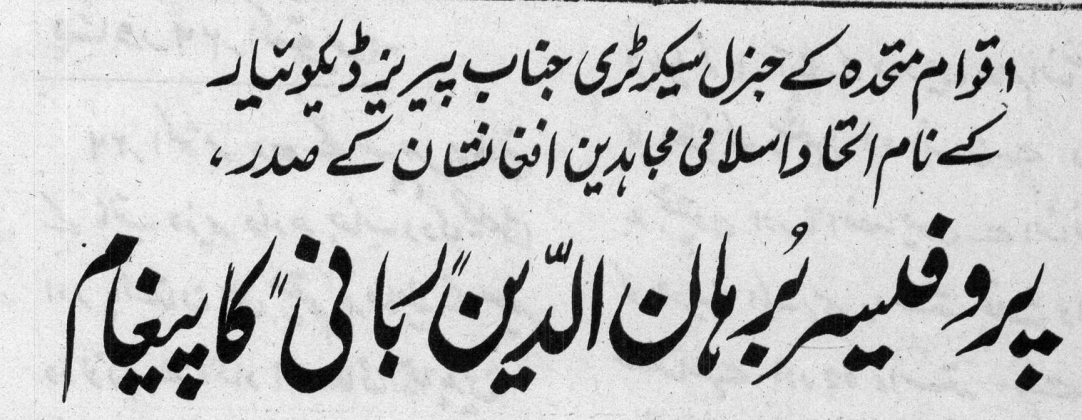

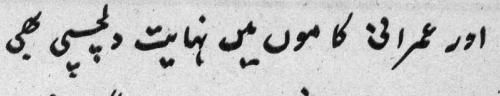

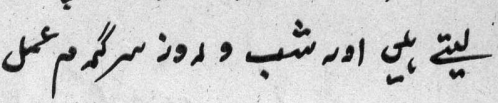
- .

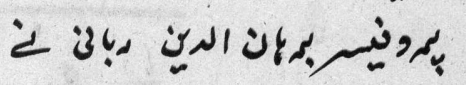

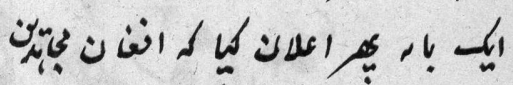

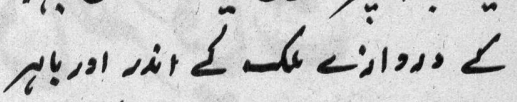

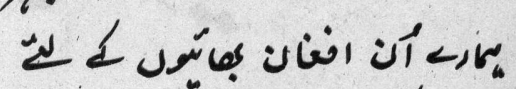

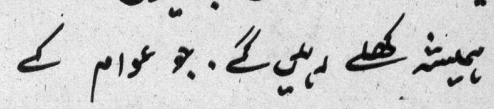

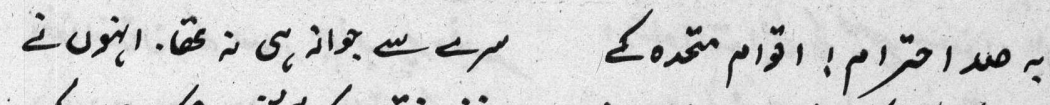

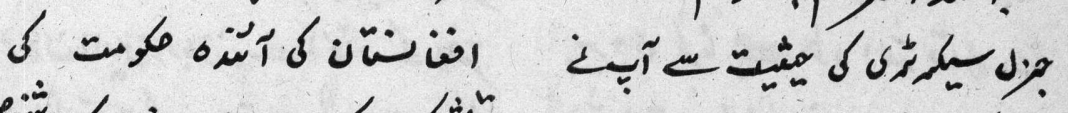

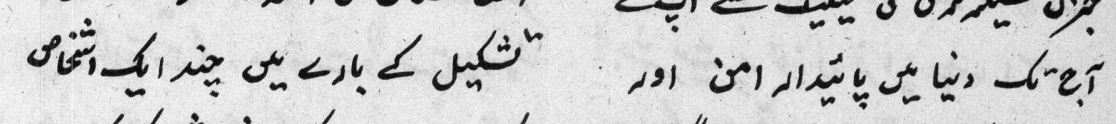

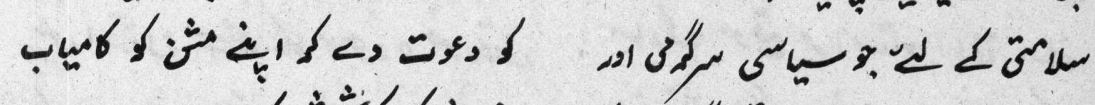

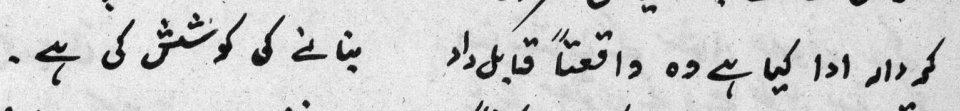

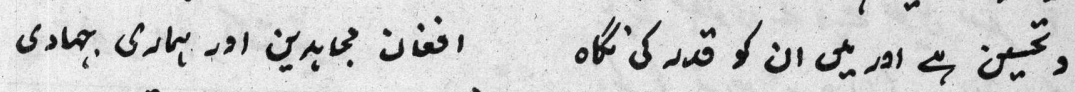

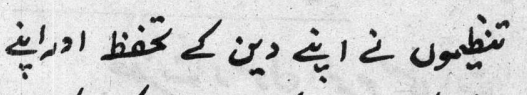

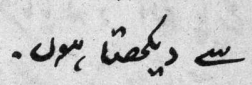

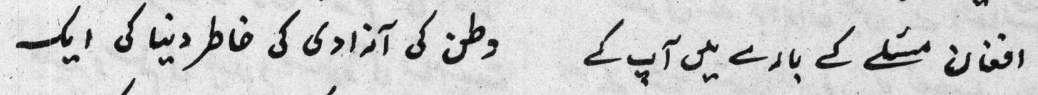

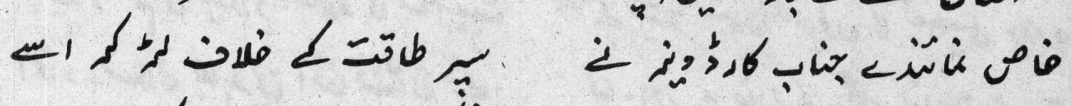
. لم

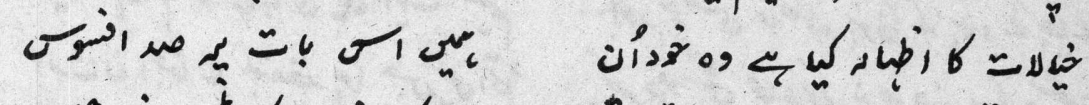

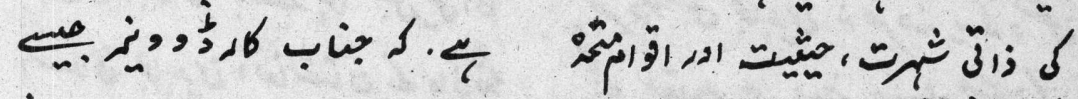
远

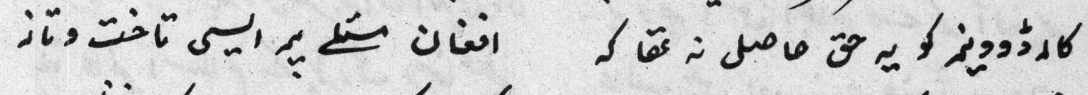

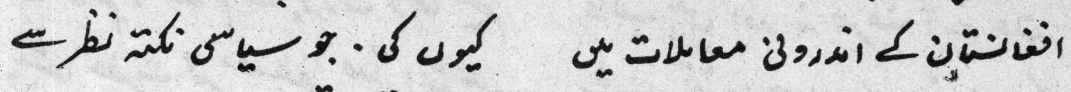

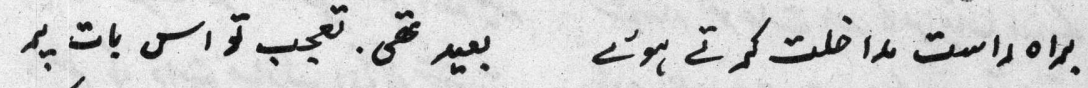

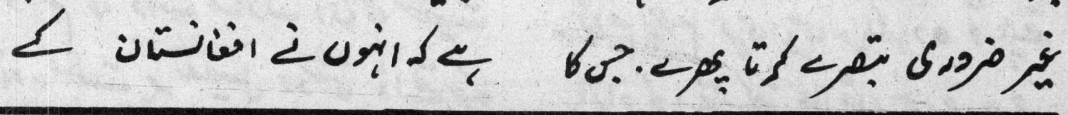


Ir

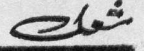

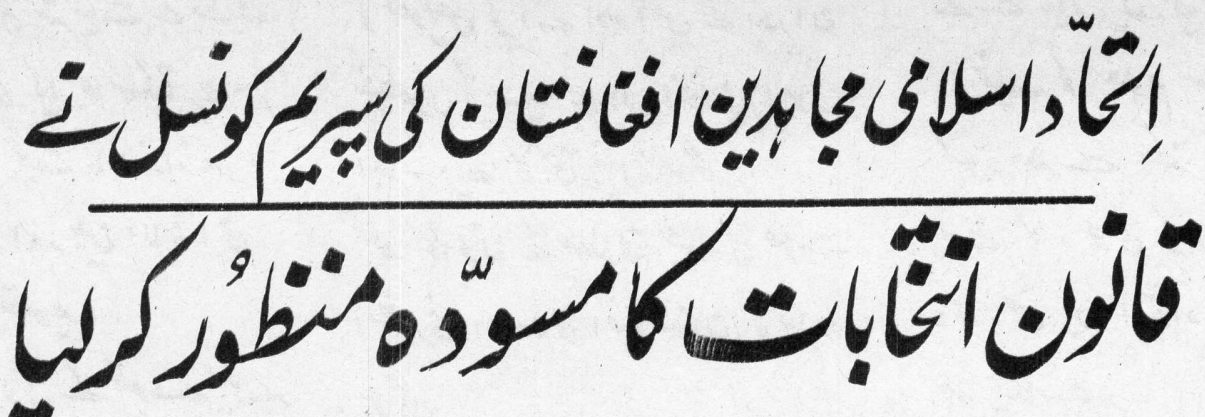

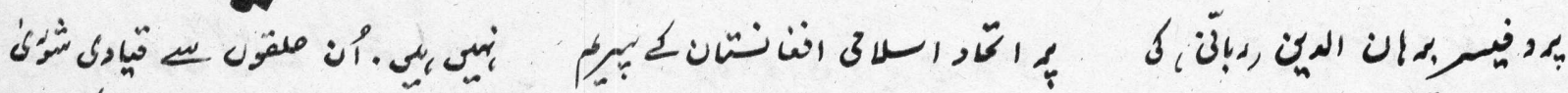

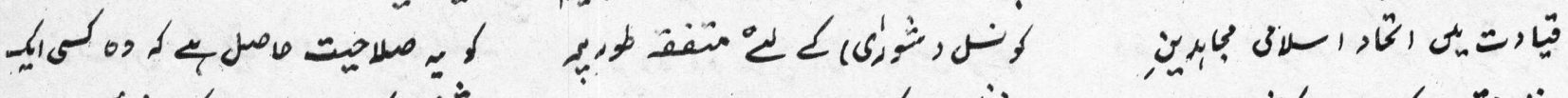

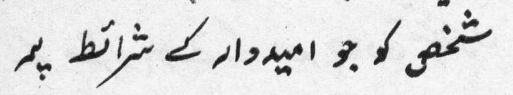

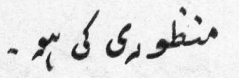

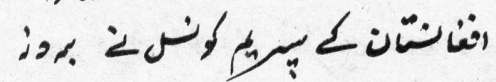

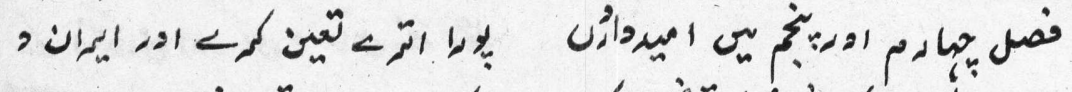

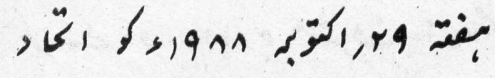

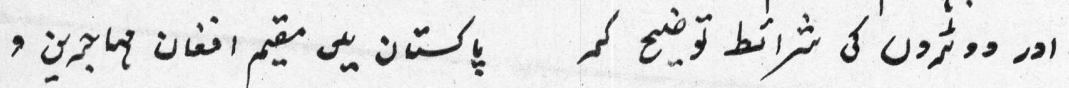

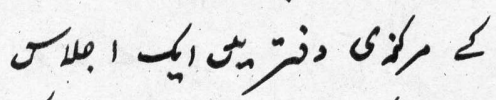

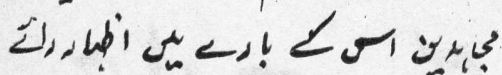

فئ"

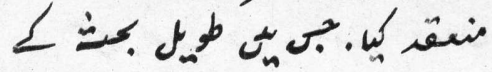

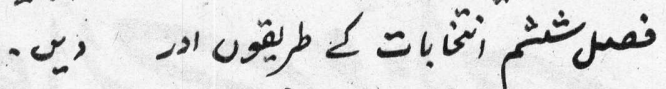

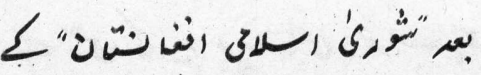

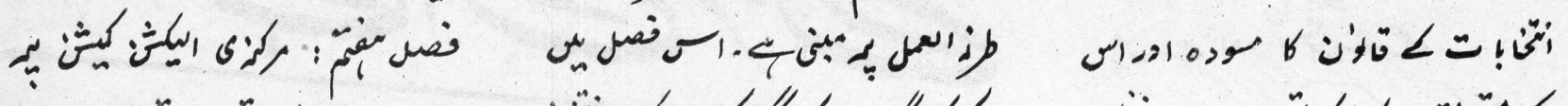

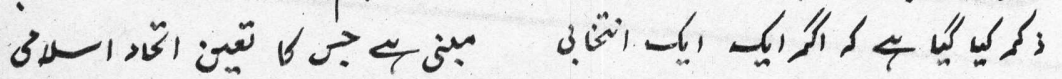

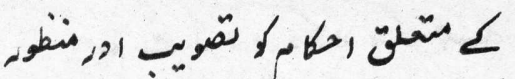

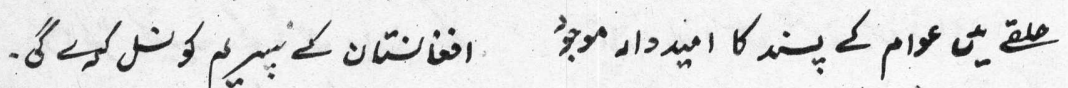

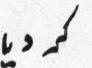

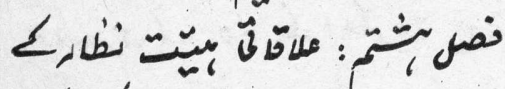

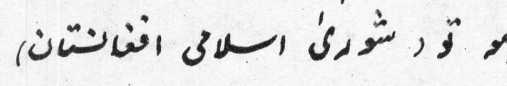

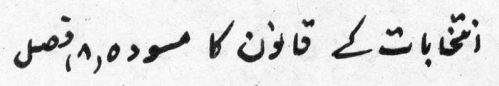

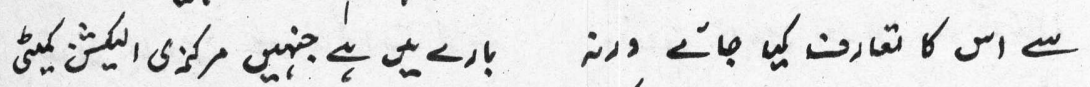

40

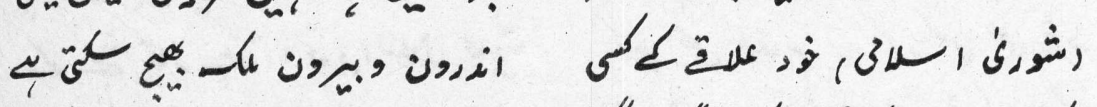

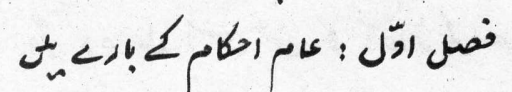

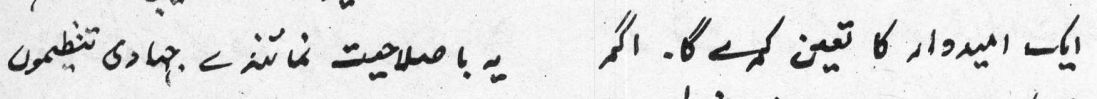

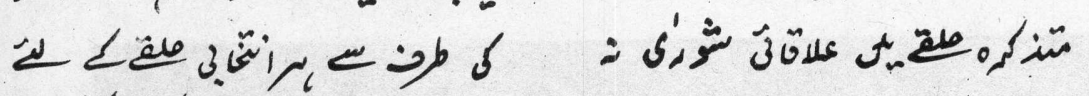

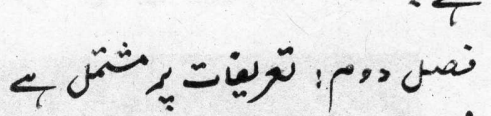

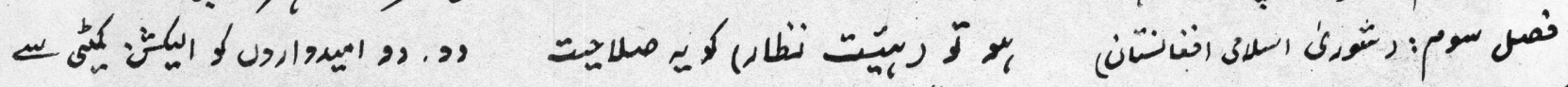

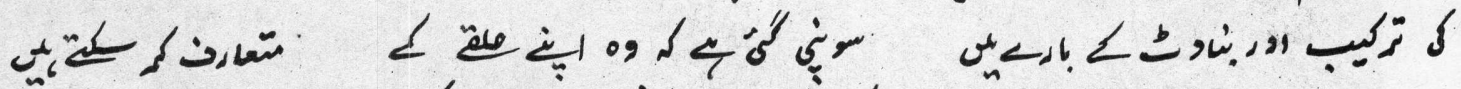

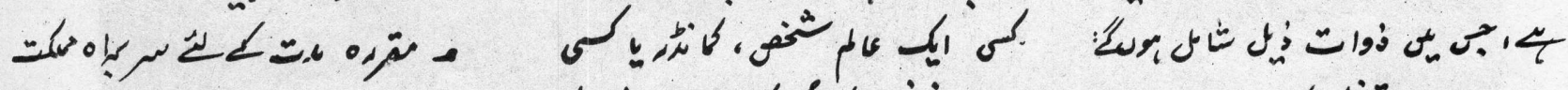

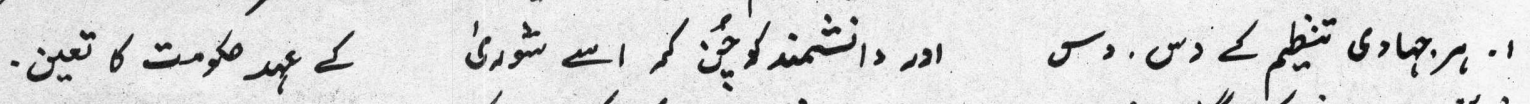

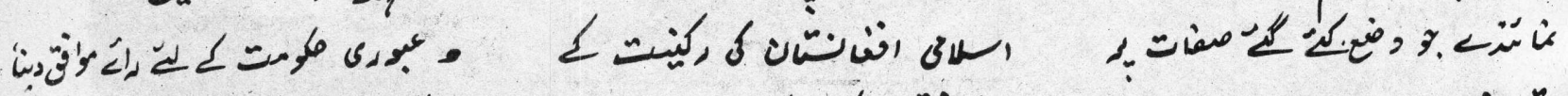

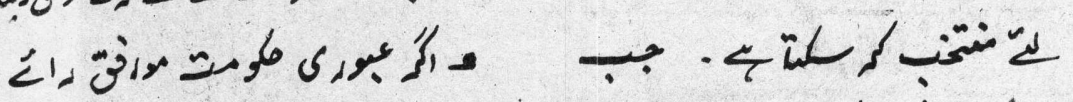

- بف

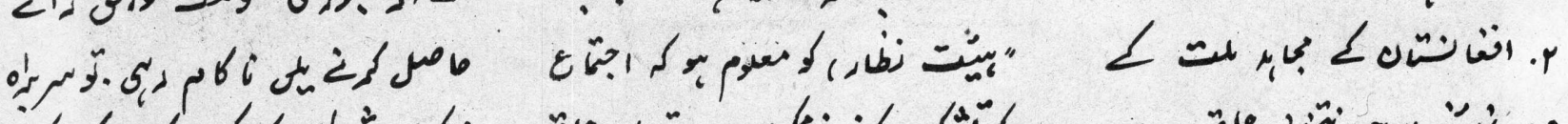

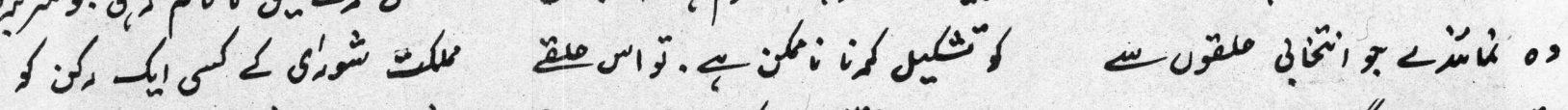

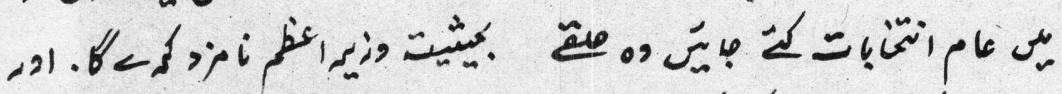

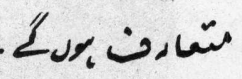

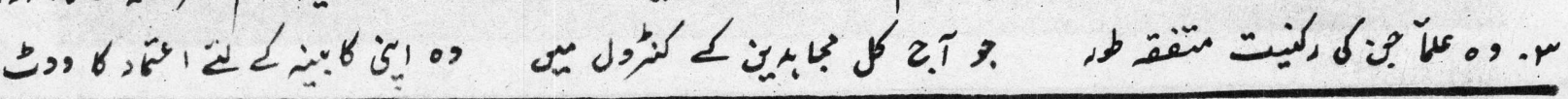


- م

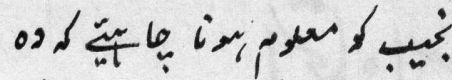

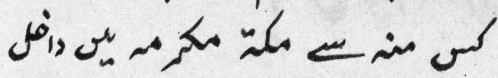
كوبن

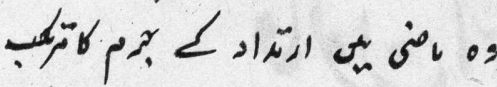
. 4 البشّخ

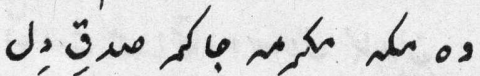
بَ كم - <ب

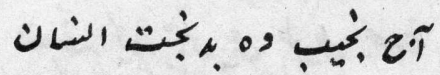

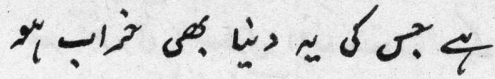

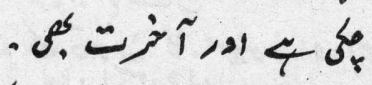
a

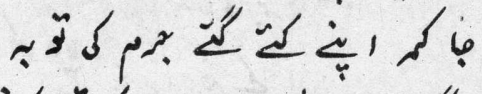

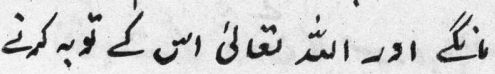

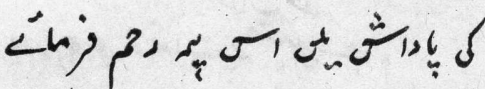

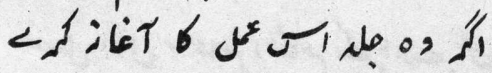
.

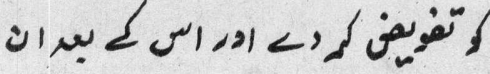

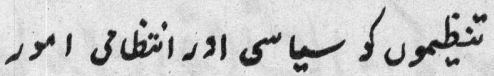

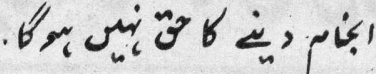

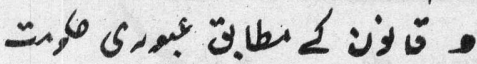

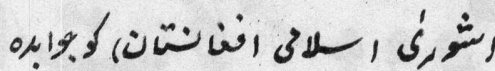

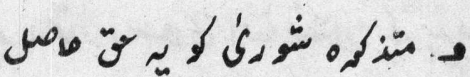

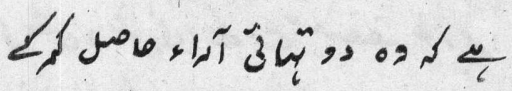

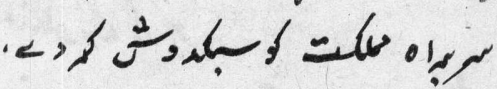

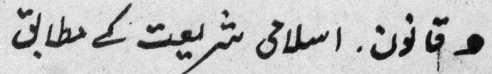

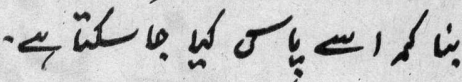

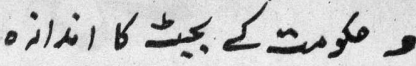

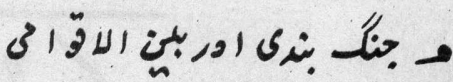

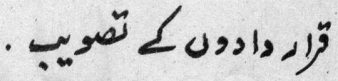

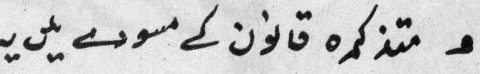

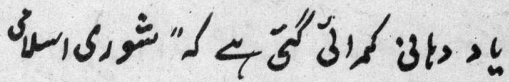

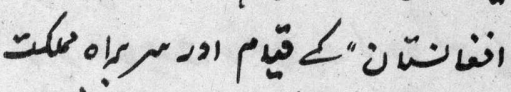

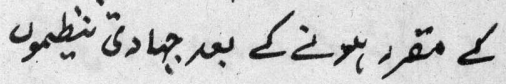

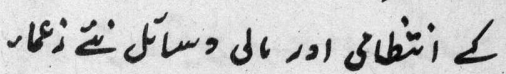

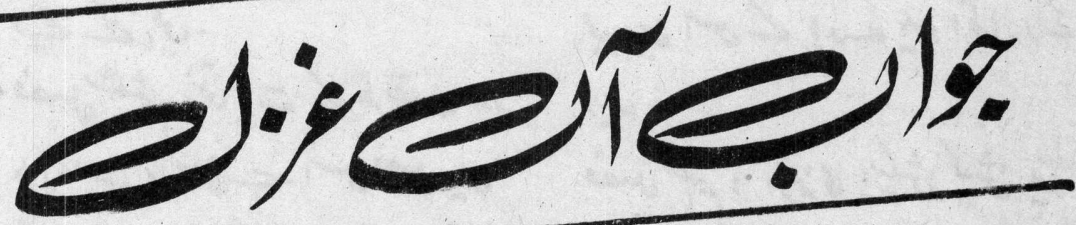

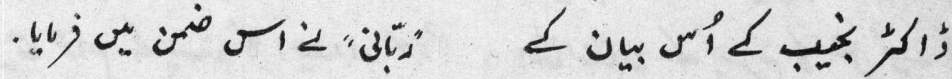

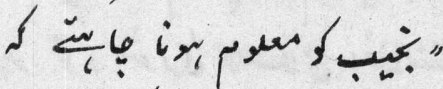

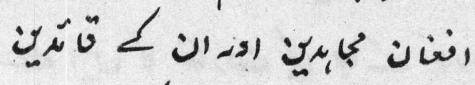

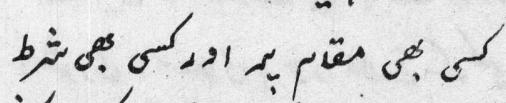

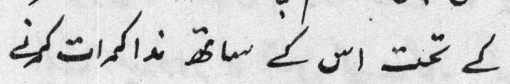

. غأن 苏

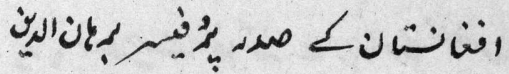

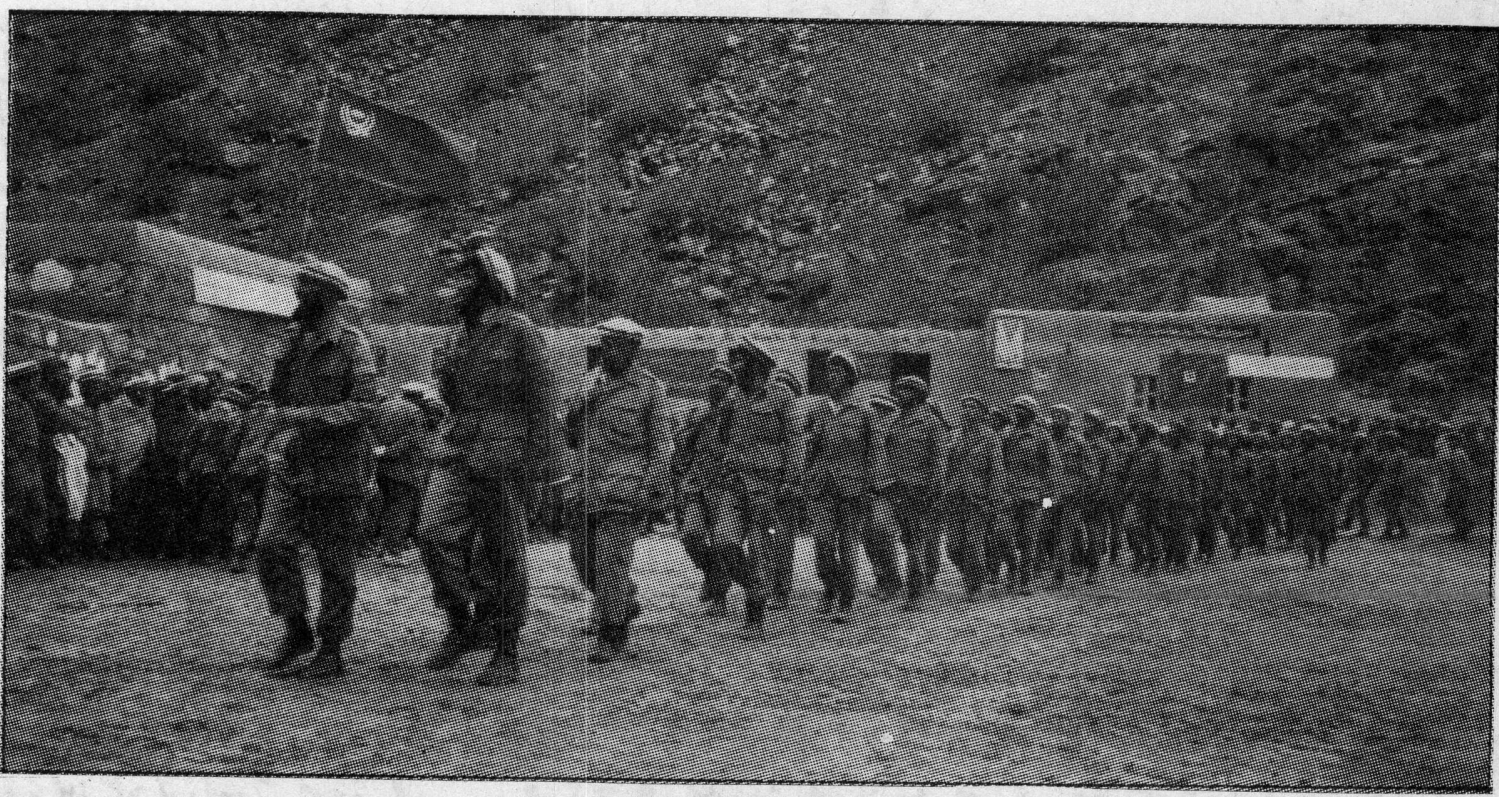


10

$0 \sin$

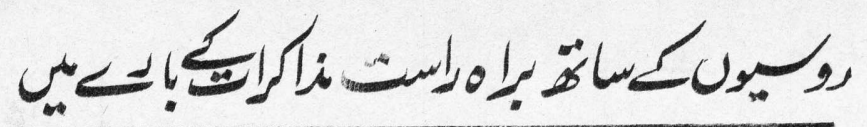

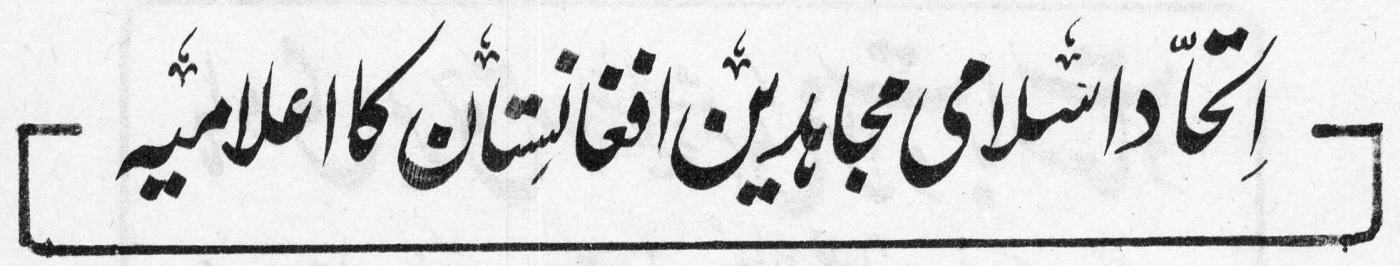

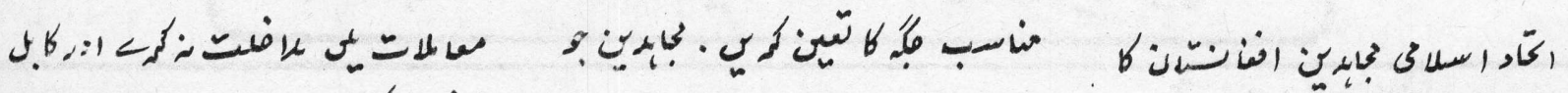

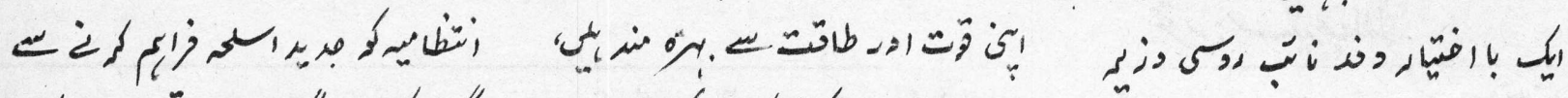

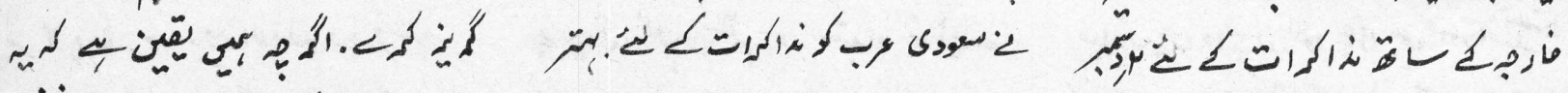
每

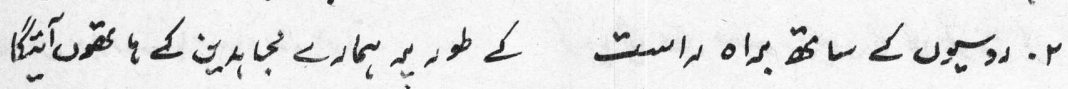
مأكاتك

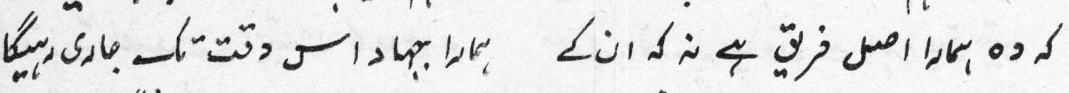

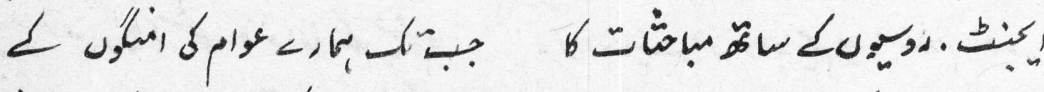

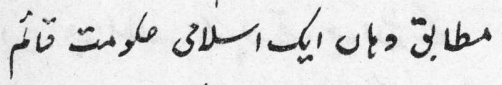
لـ كا

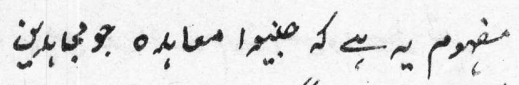

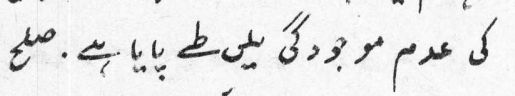

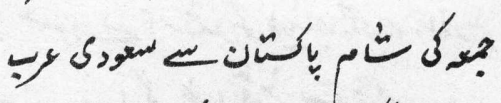

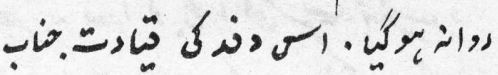

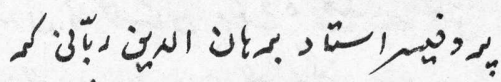

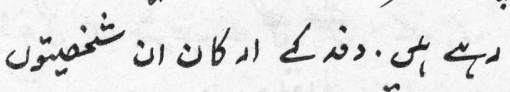

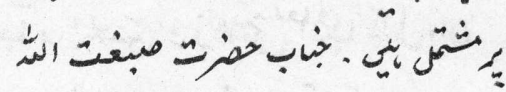

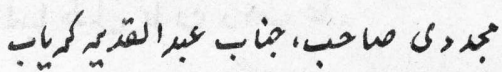

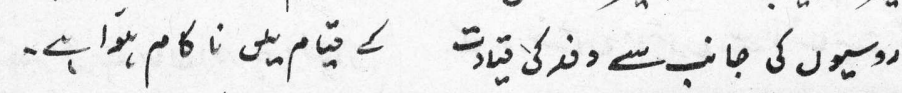

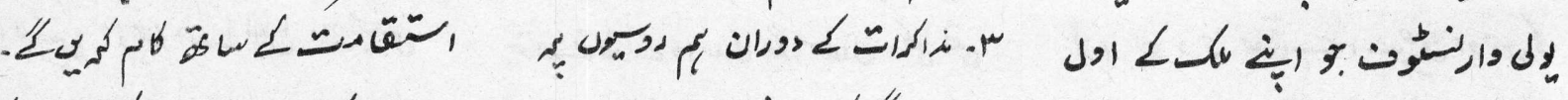

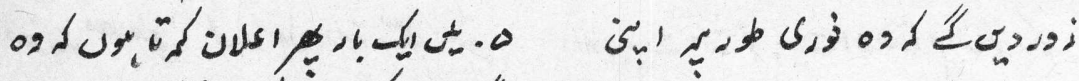

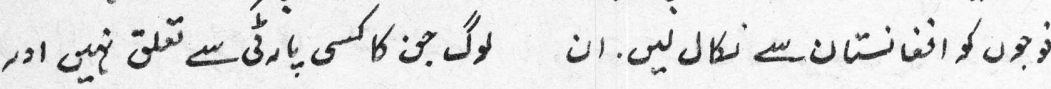

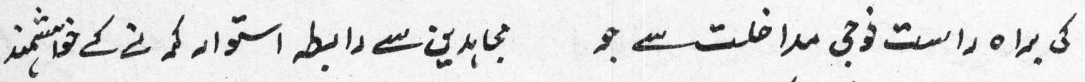

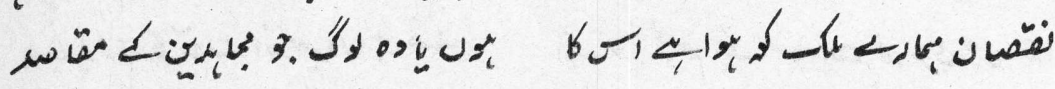

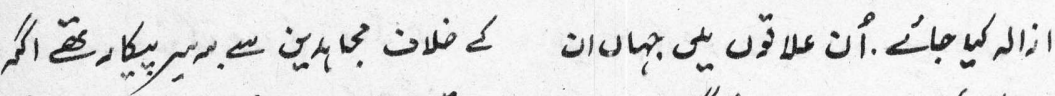

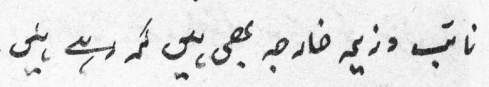
管

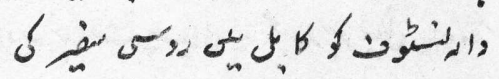

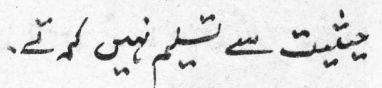

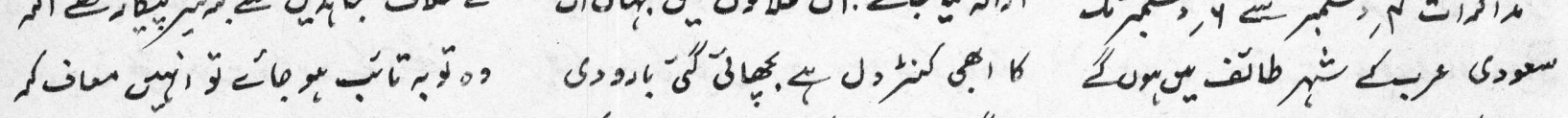

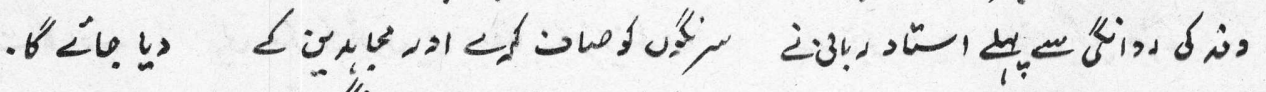

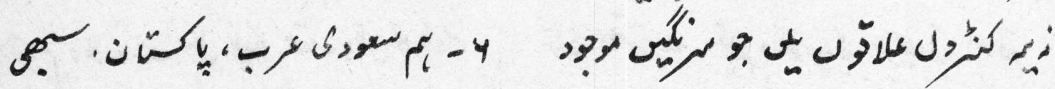

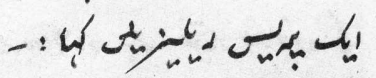

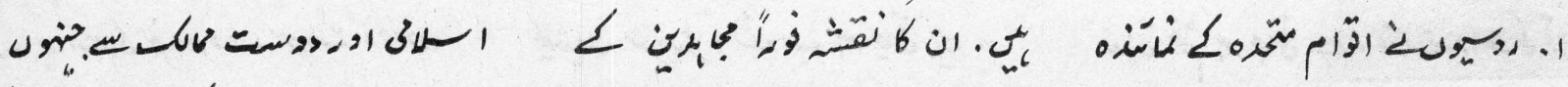

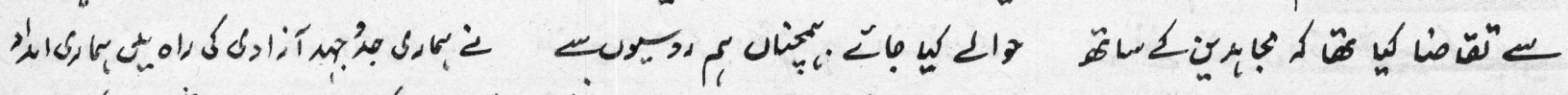
. 


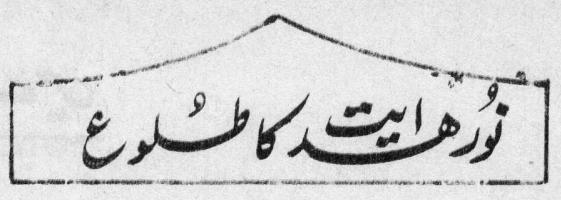

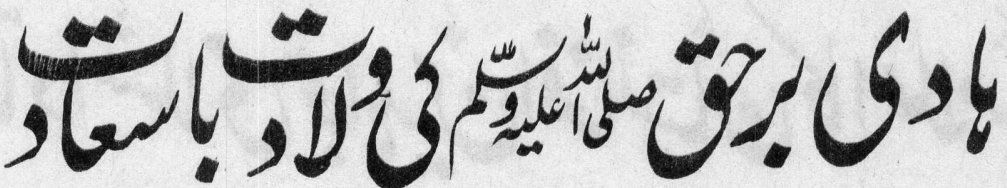

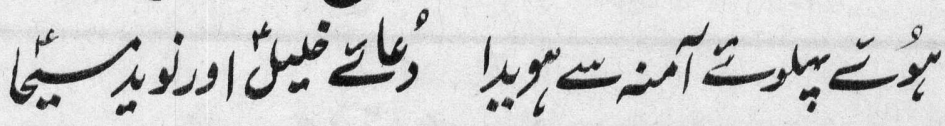

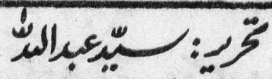

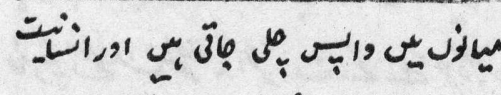

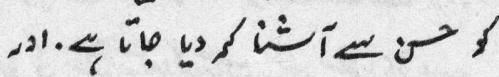
,

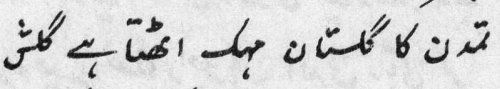

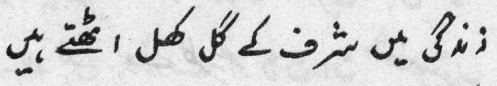

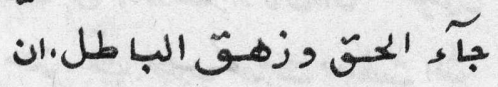

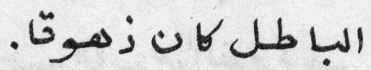

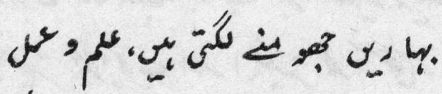

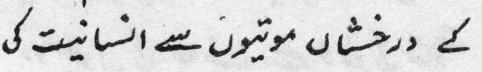
",

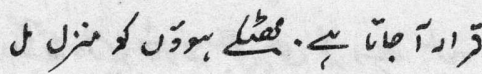

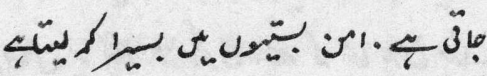
.

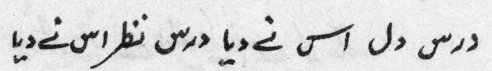
1ا

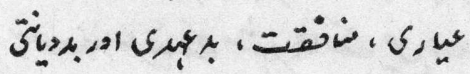

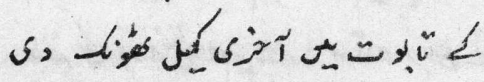

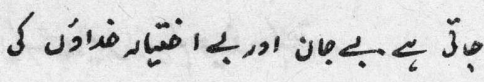

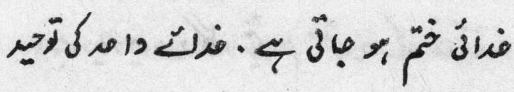

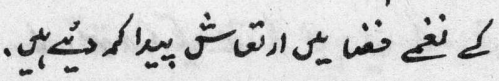

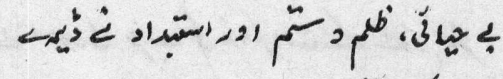

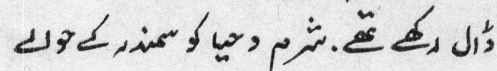
|

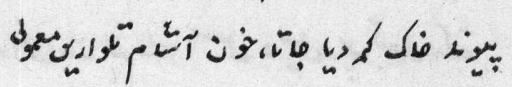

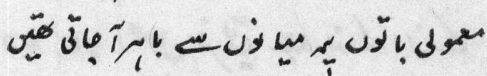

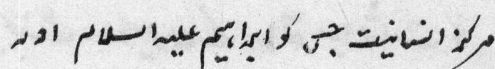

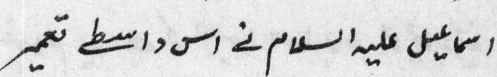

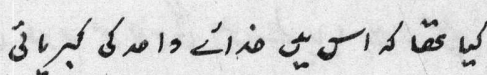
|

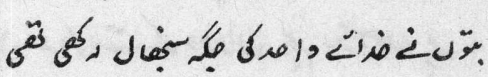

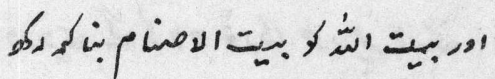

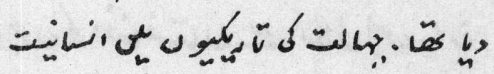
ك

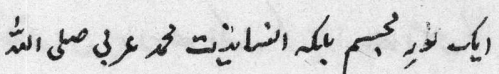

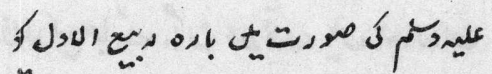
3.

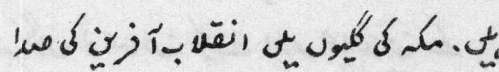

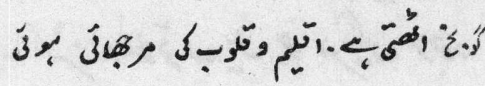

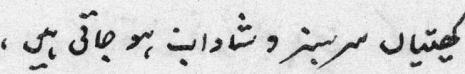

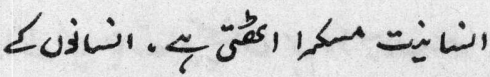
定

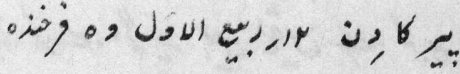

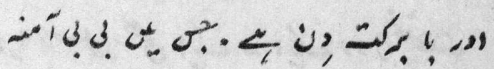
.

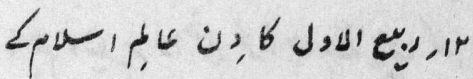

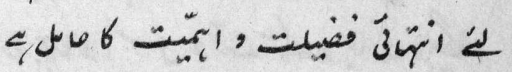

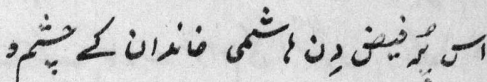

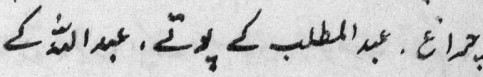
亡

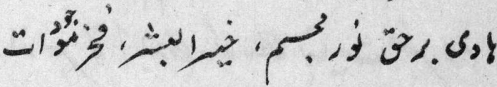

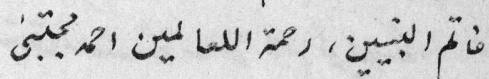

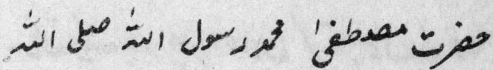

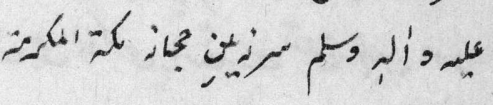

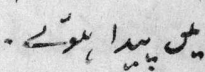
جب بائ

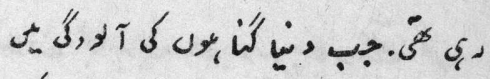

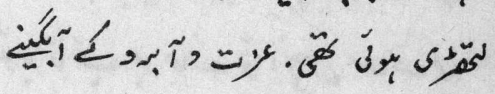

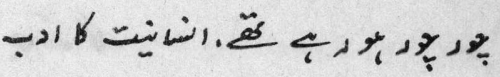

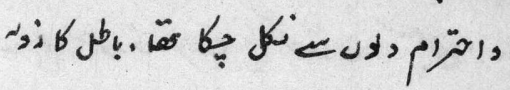

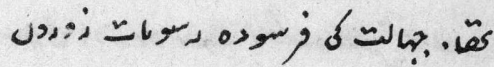

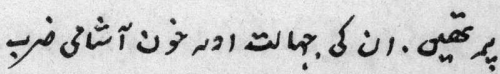

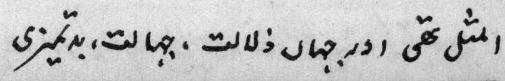


avi

11

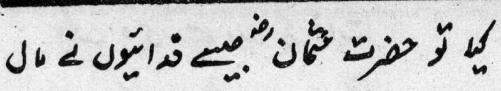

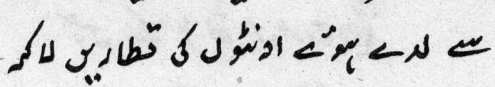

空

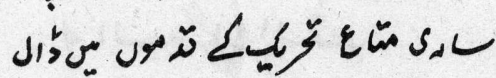

20

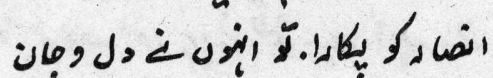

ए

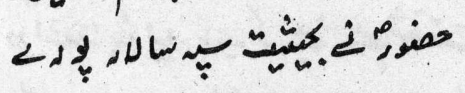

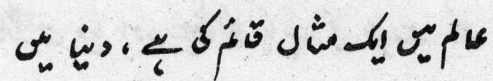

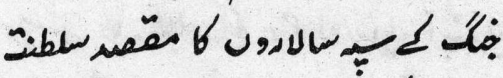

9.

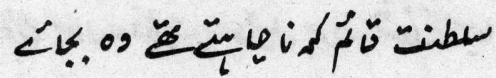

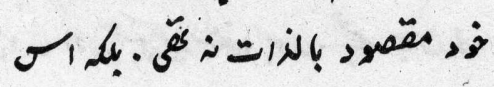

مك

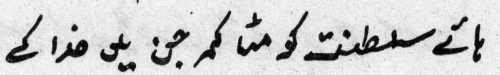

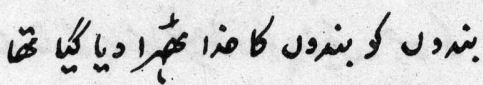

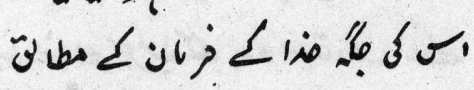

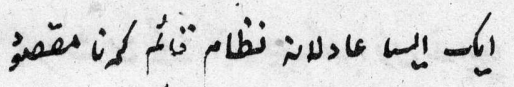

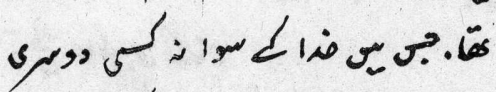

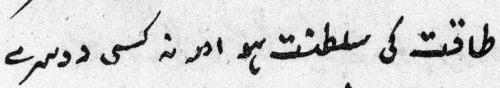

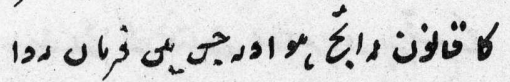

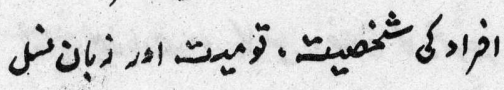

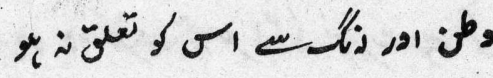

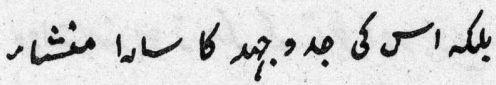

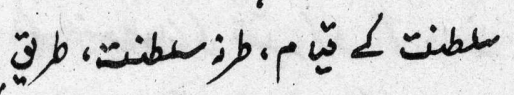

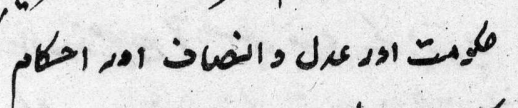

ك

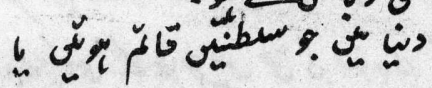

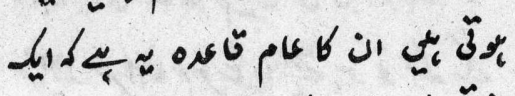

ن

侻

(1)

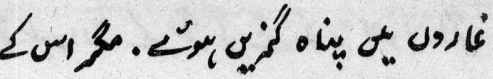

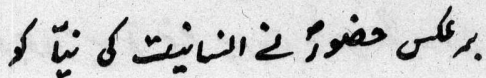

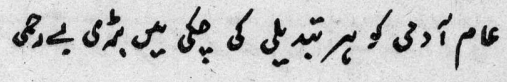

(1)

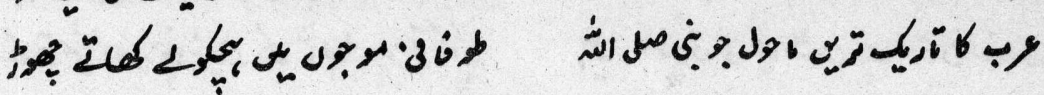

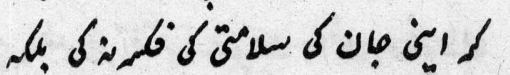

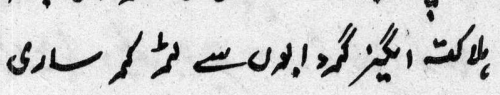

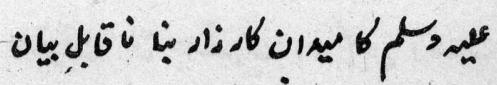

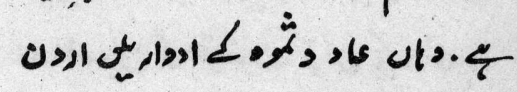

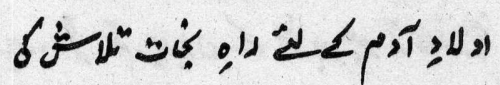

政"

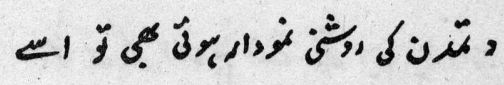

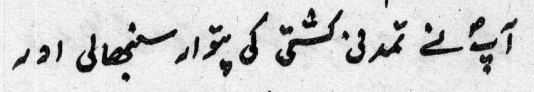

ع.

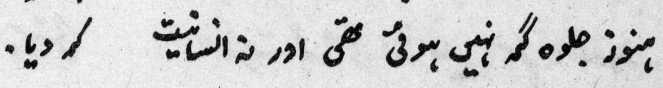

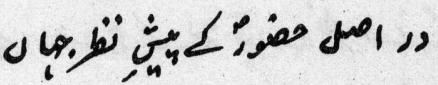

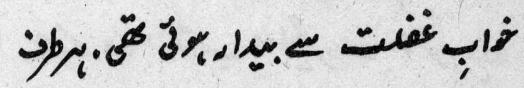

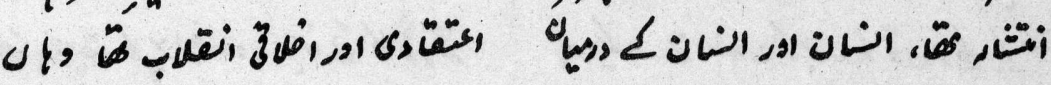

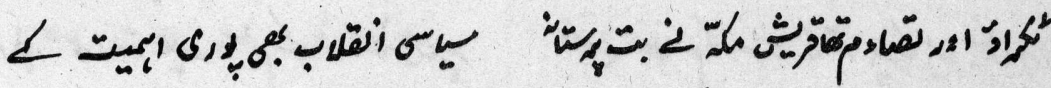

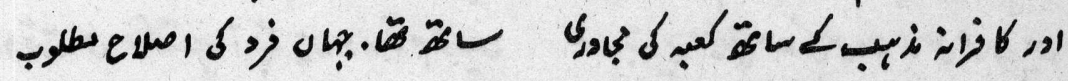

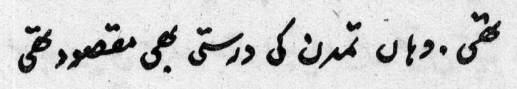

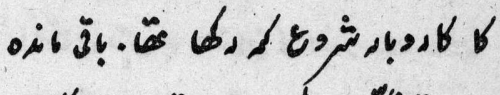

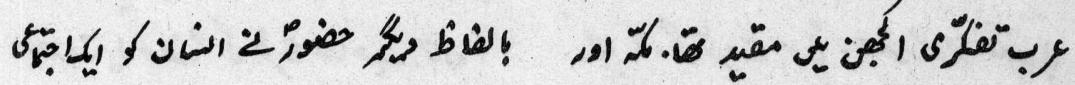

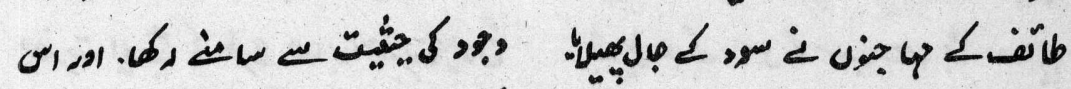

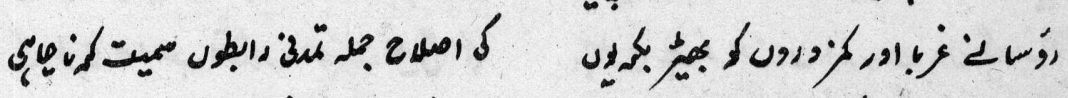

منّ人

6 6 \%

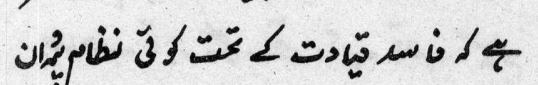

:

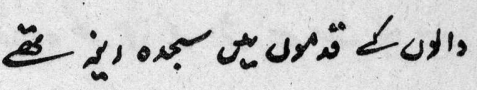

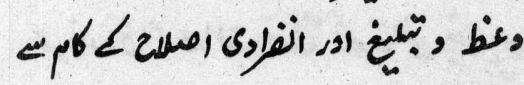

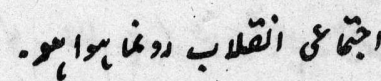

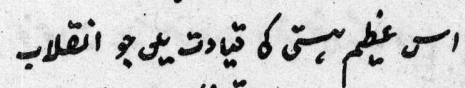

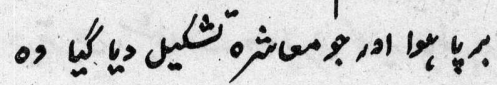

ك

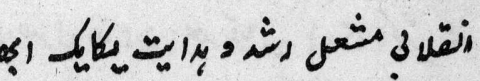

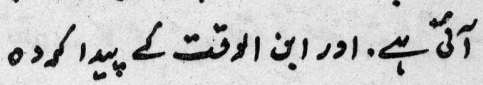

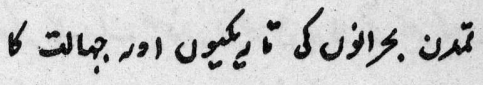

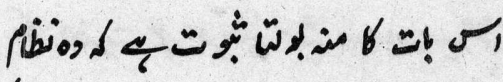

—

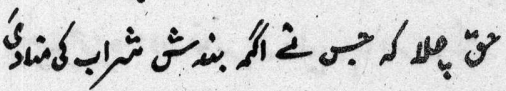

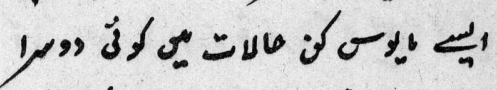

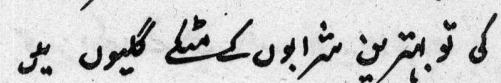

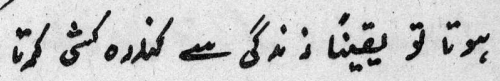

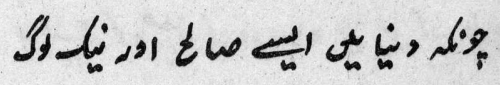

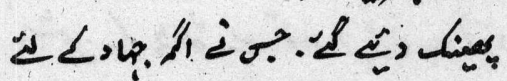

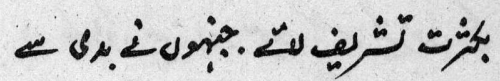

二

نغ

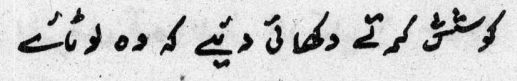

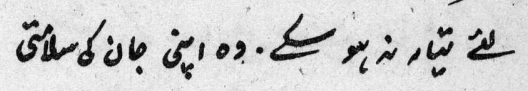

定 
19

ثي

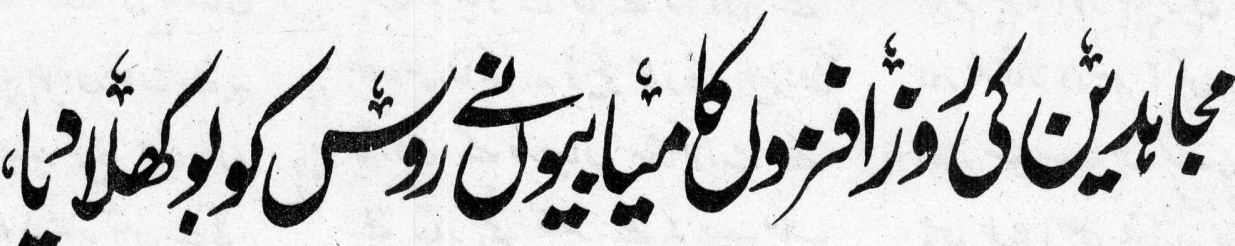

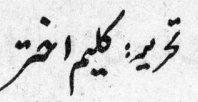

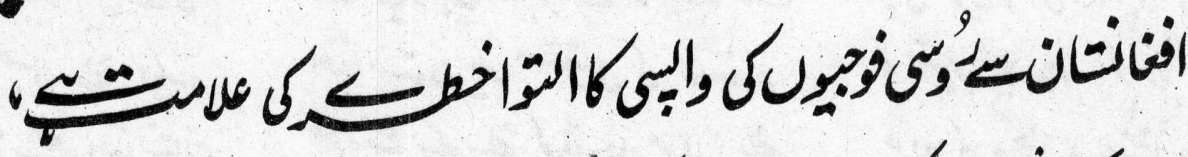

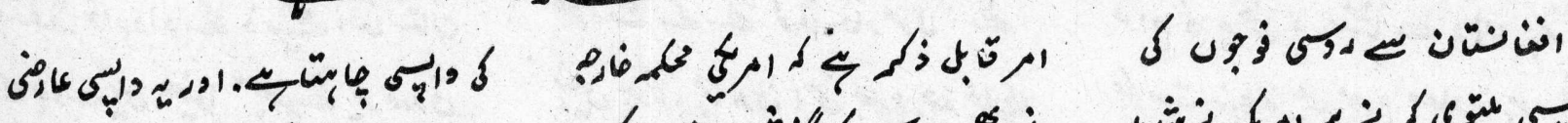

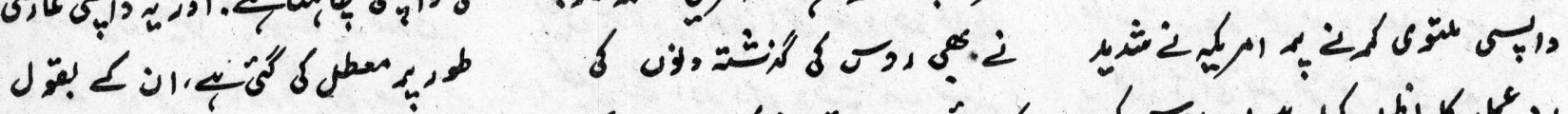

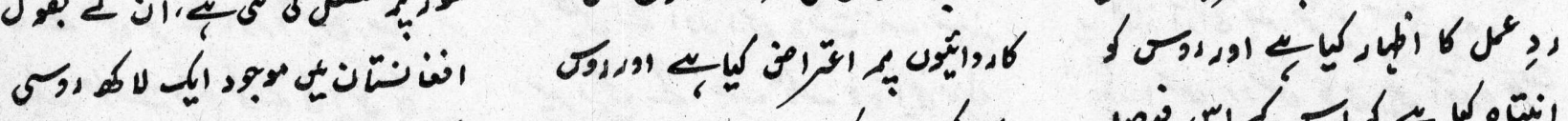

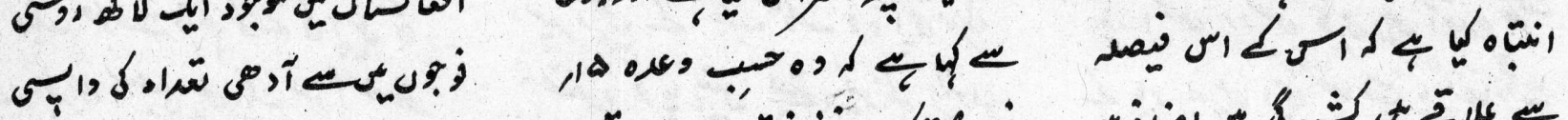

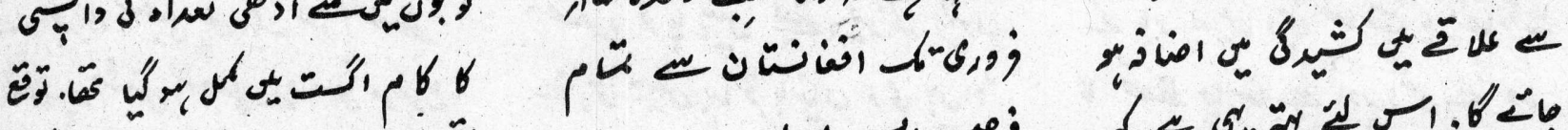
界

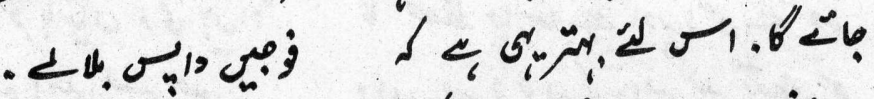

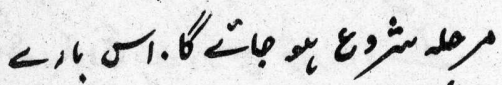

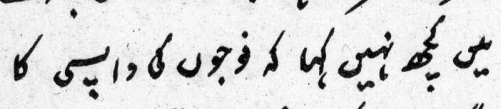

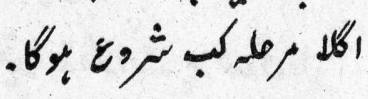

الم

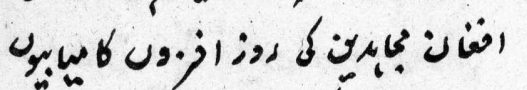

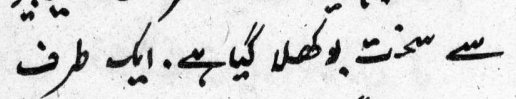

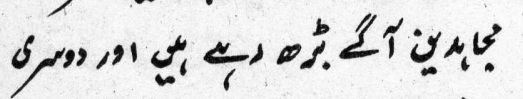

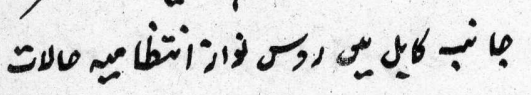
गी

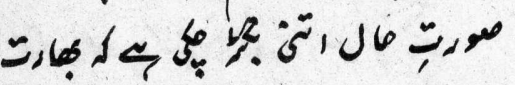

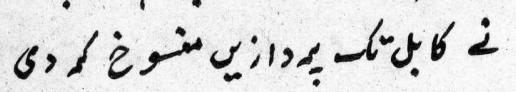

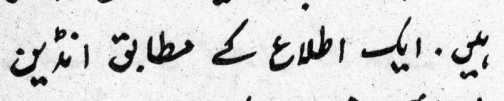

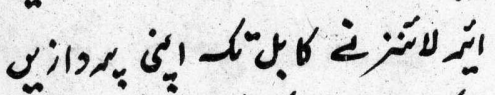

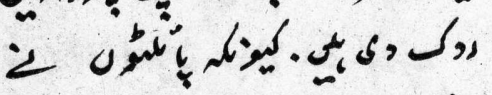

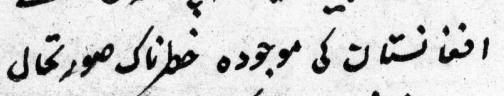

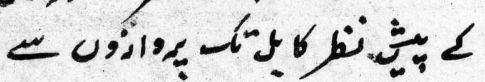

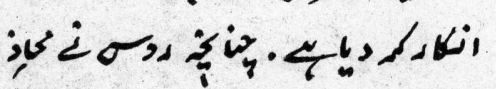
1 م هبنيا

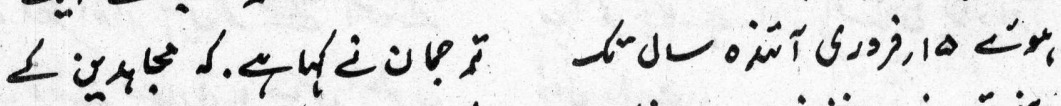

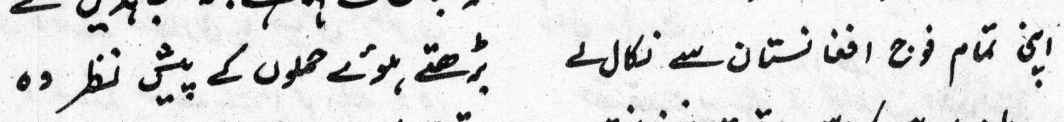

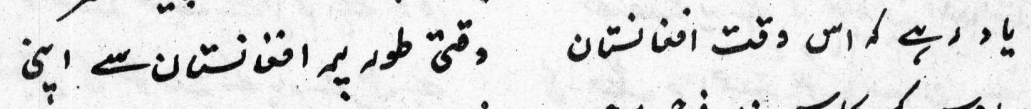

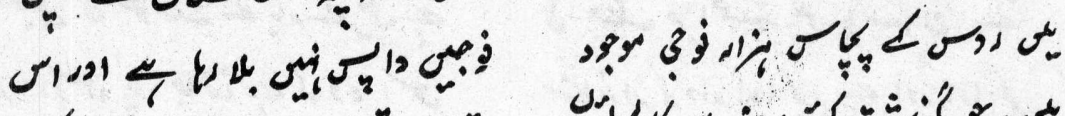

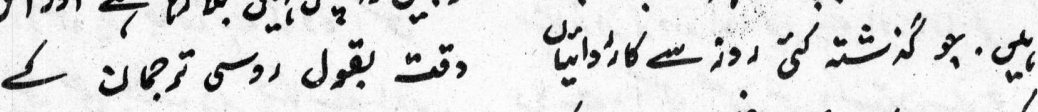

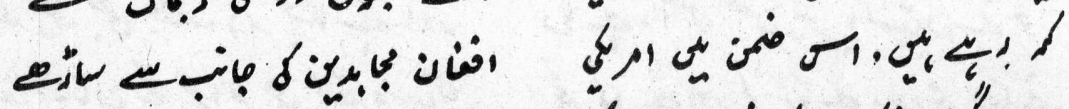

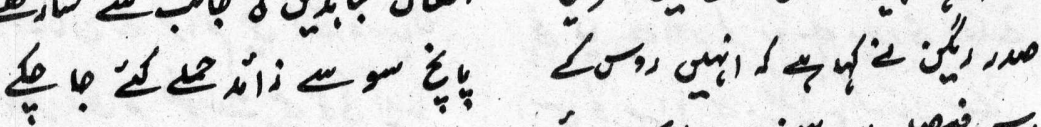

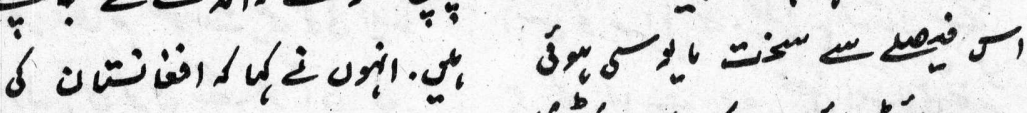

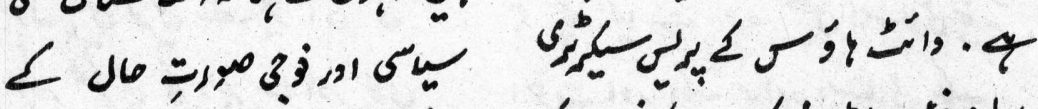

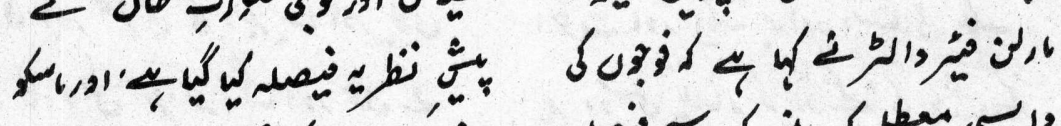

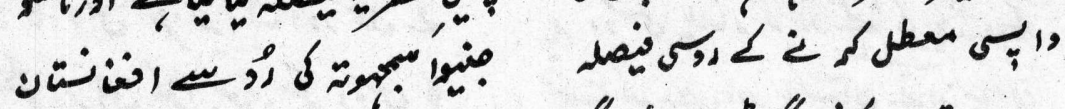

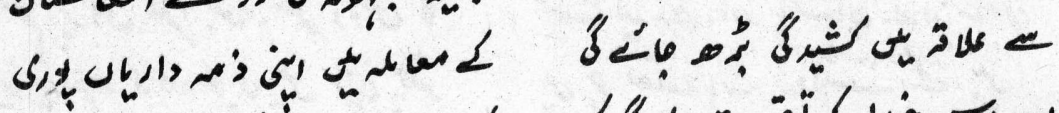

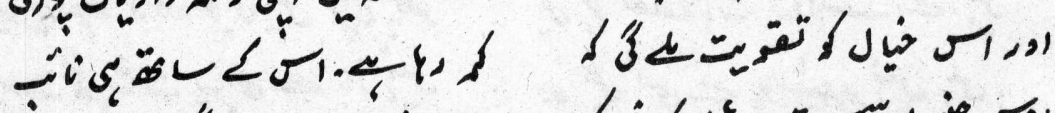

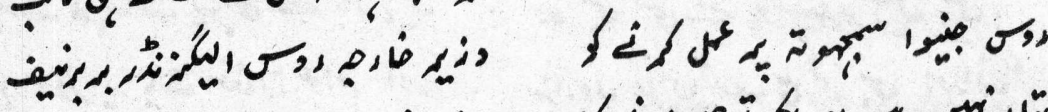
ئن

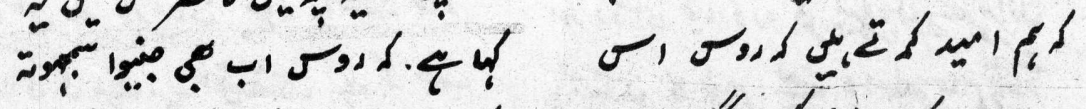

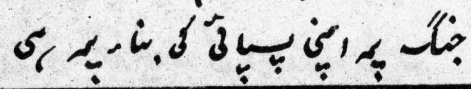

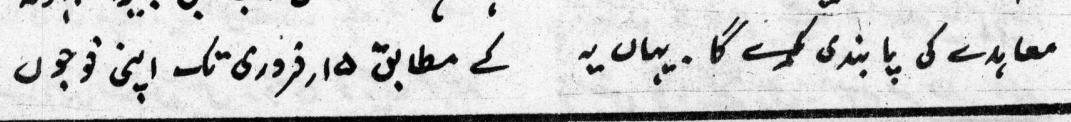


$=4$

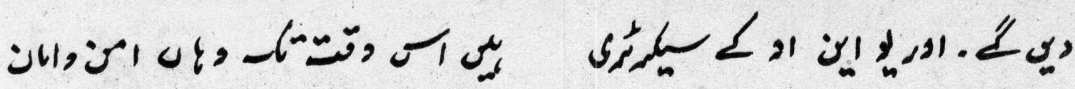

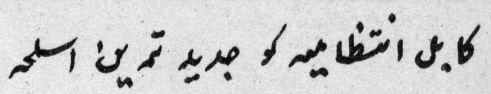

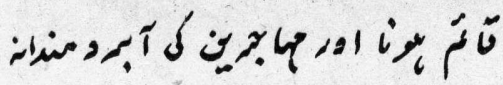

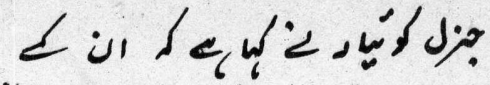

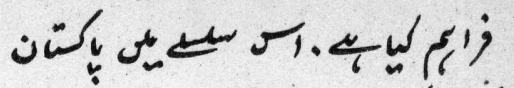

إنان

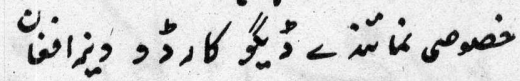

2

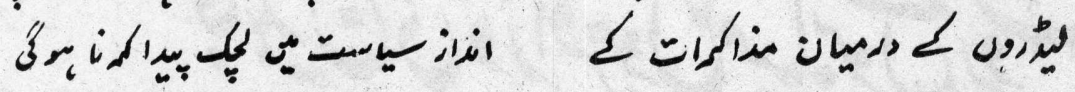

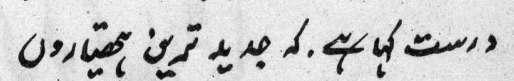

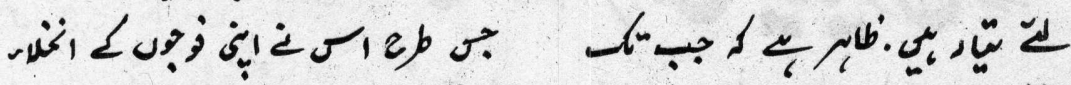

行

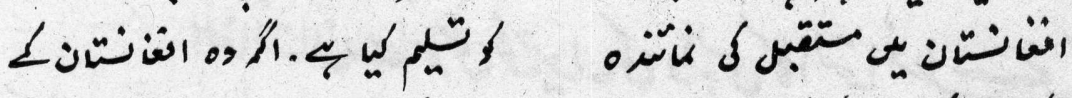

لئه

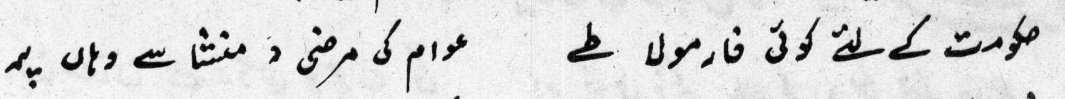

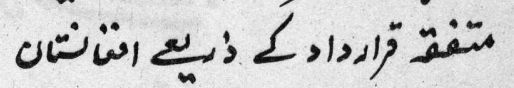

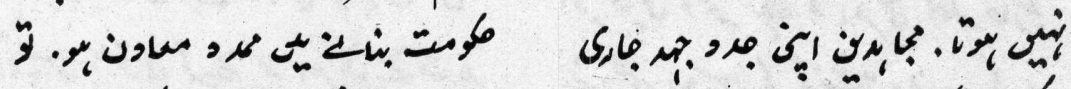

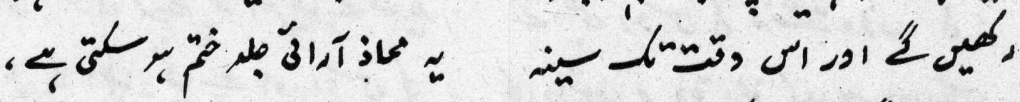

L

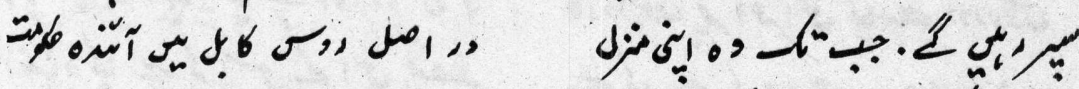

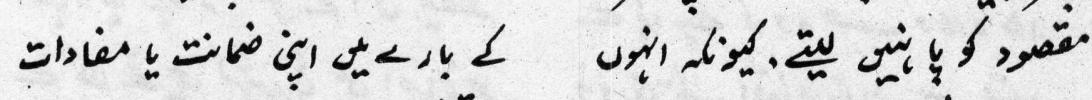

它

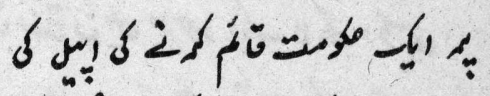

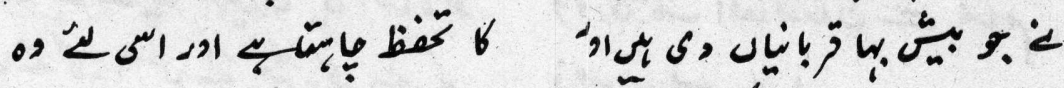

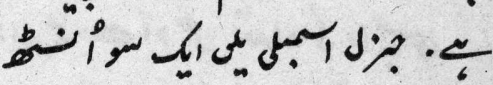

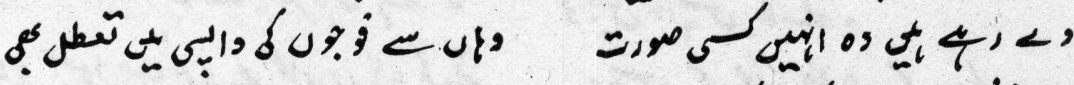

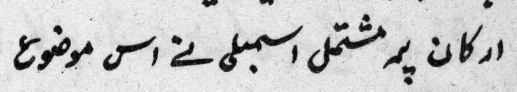

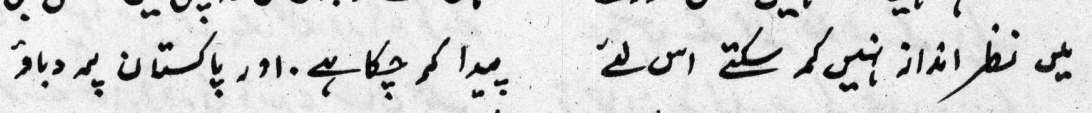

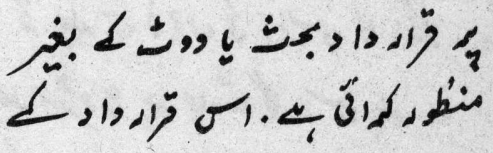

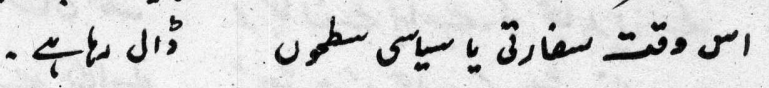

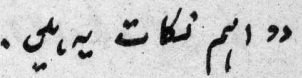

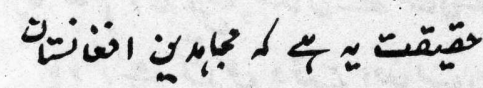

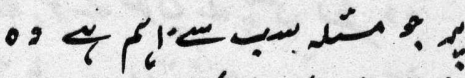

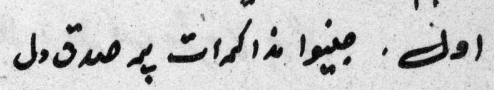

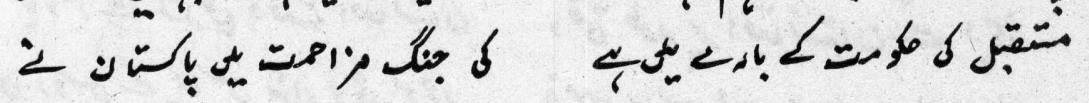

(19)

لر

年

أنس

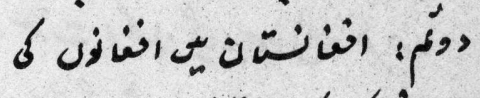

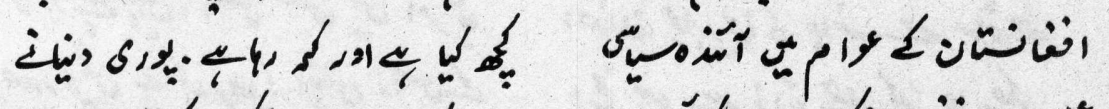

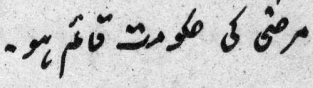

ट

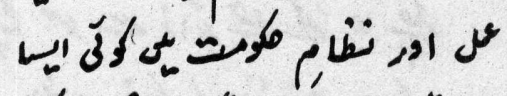

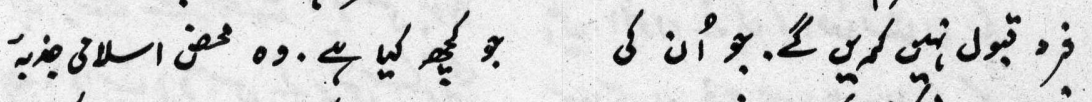

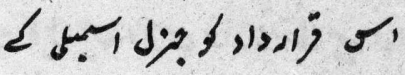

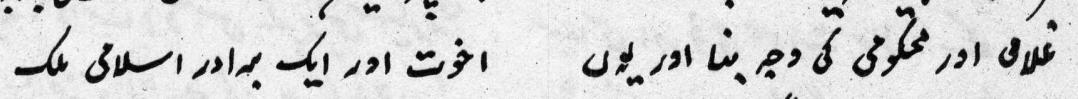

كان

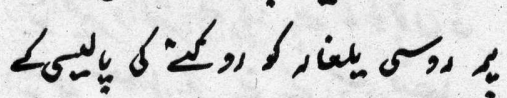

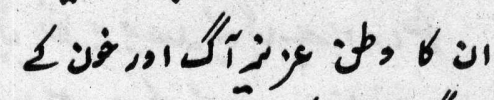

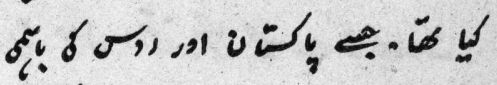

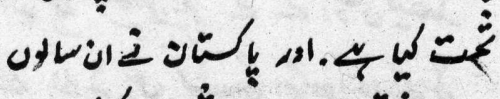

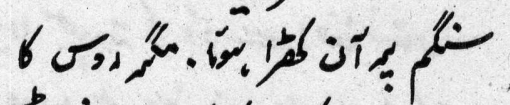

.

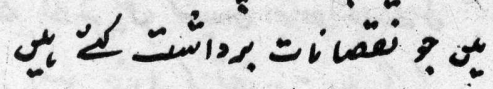

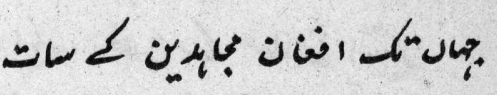

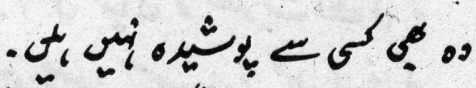

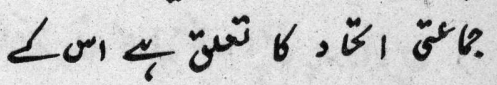

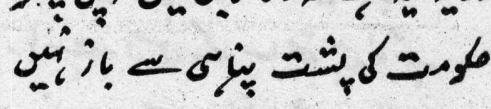

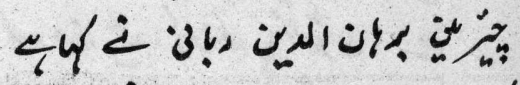

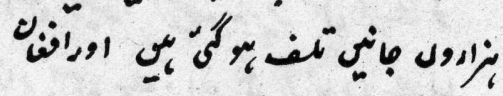

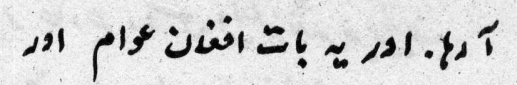

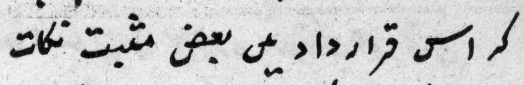

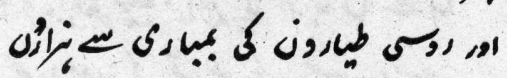

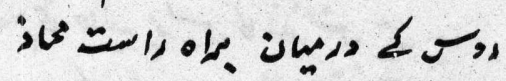

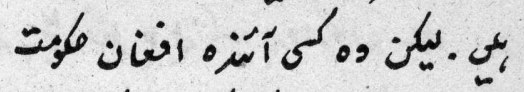

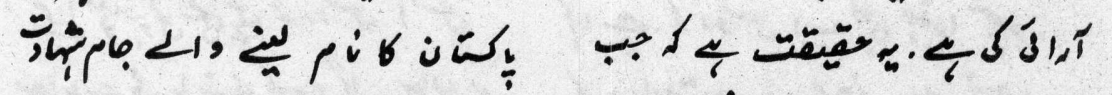

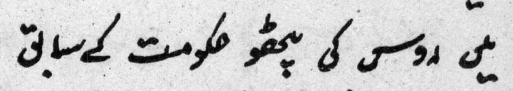

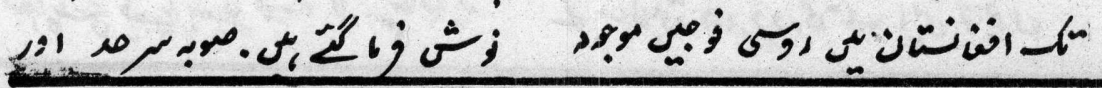

ني 


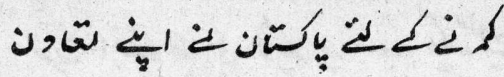

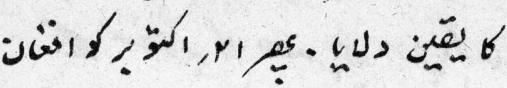
$\ddot{~}$

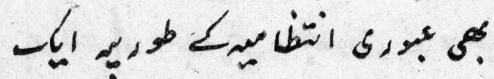

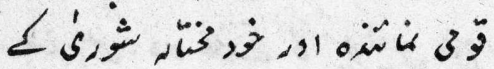

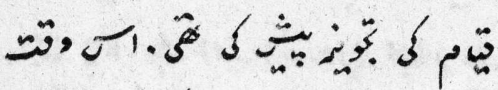

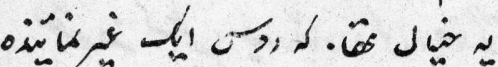

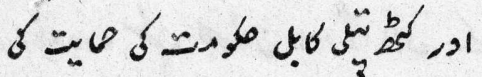

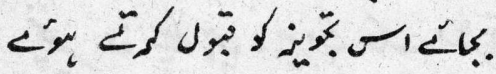
ان بن L حس

$$
-4.40
$$

أن أن

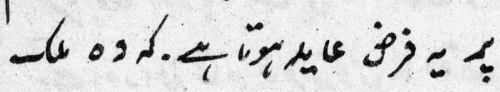

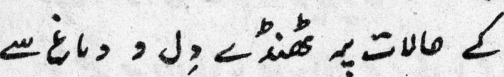

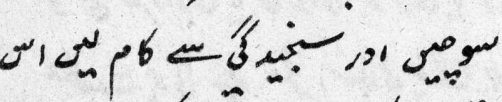
وמש \%

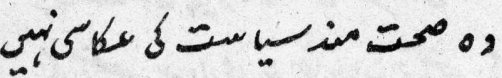
ك 45,60 :

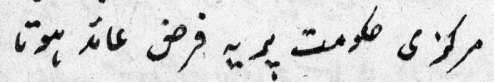
ن ए人 ه.

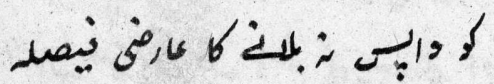
i

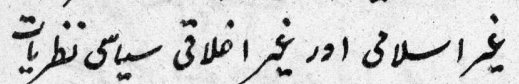

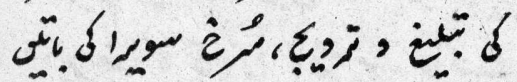

ك

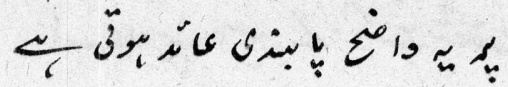

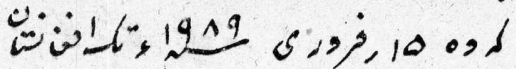

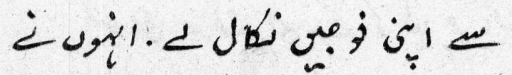

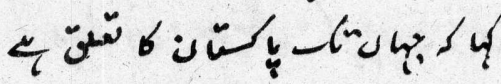
ए人

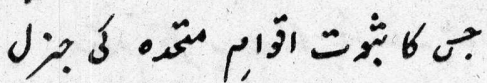

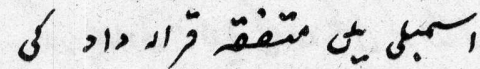
- $\sim \mathcal{G}, \dot{\text { in }}$

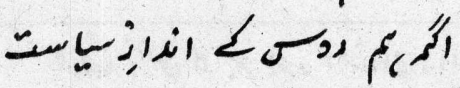

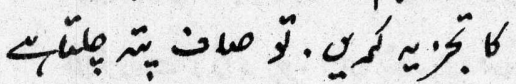
ك

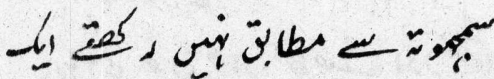
\% os d. $\frac{2}{6}$ th J 6 6 ن rll

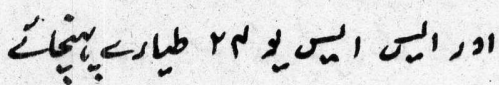

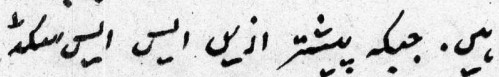
كiv.

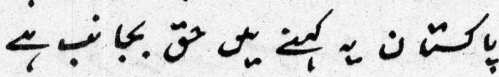
ن ك L ن $\sigma, 1 . \div 20=16$,

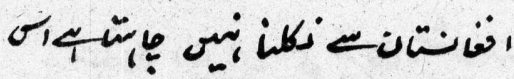

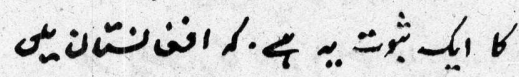

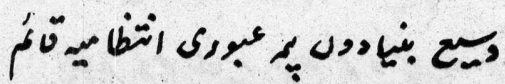

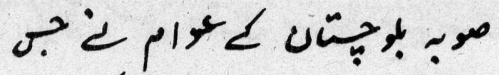

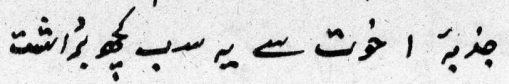

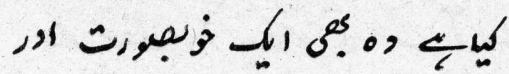

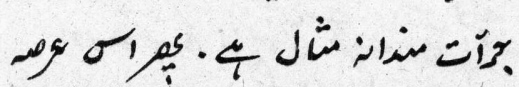

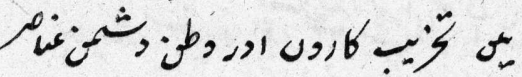
د 2 ن

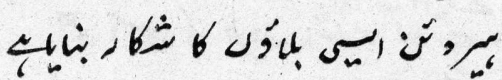
ים

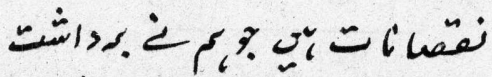

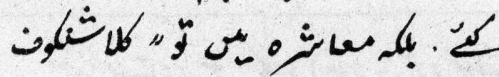
ئ

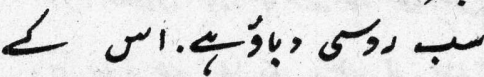

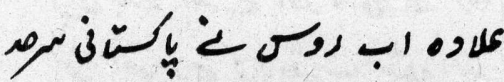

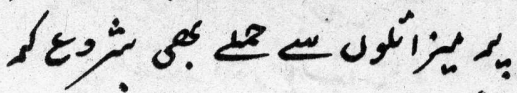
L

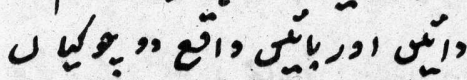

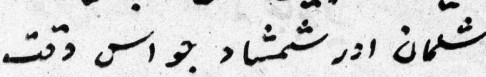

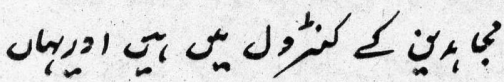

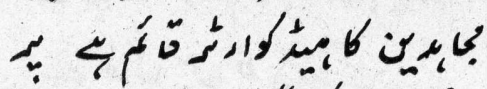

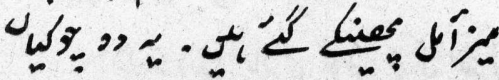

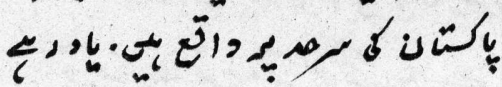

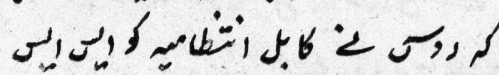

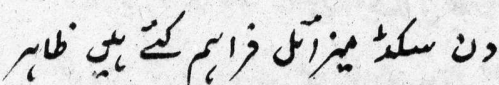

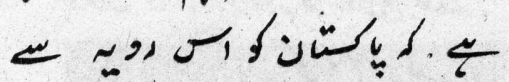

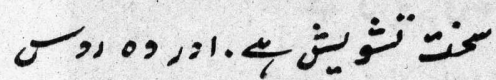

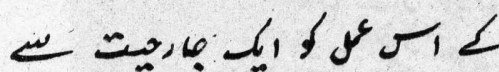

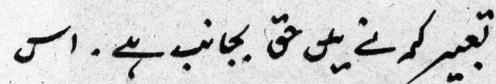

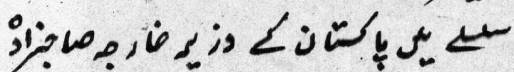

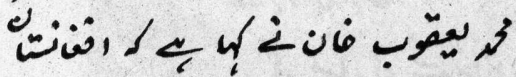

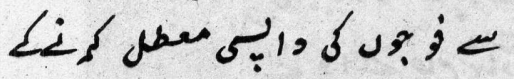

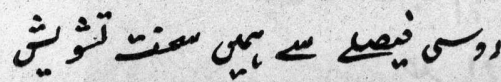




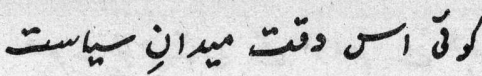
ن ك كَفط ا 品

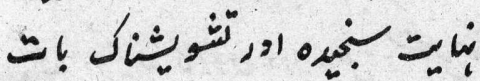

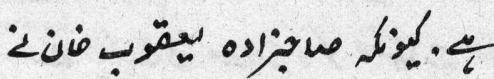
ه .

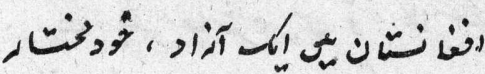
䧄

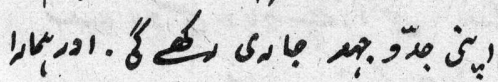

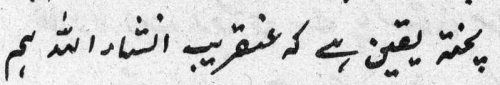

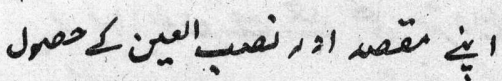

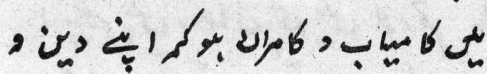

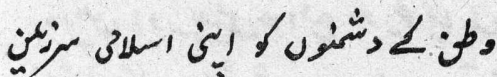

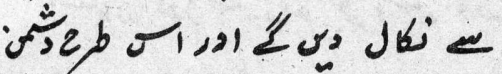

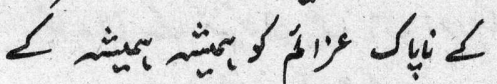

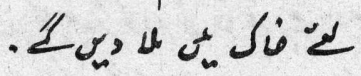

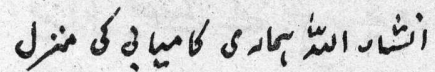

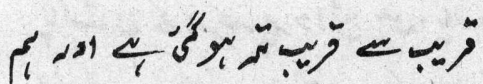
ك以

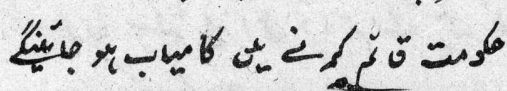

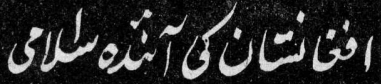

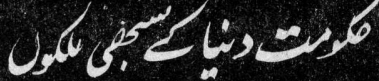

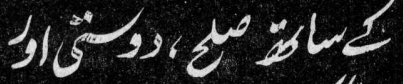

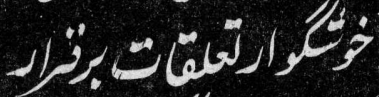
$6 \div 6100$

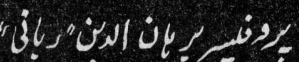

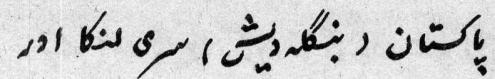

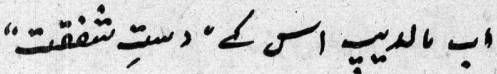
- 6

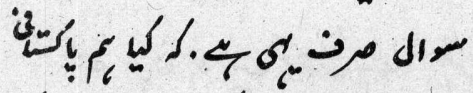

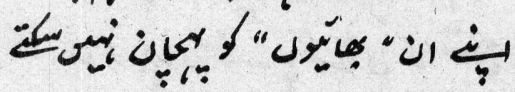

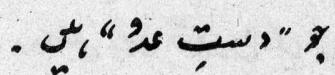

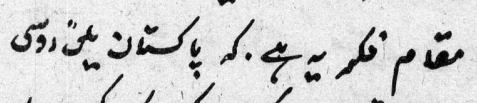

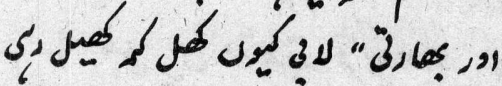
و

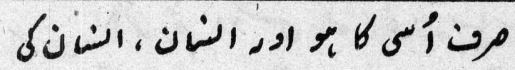

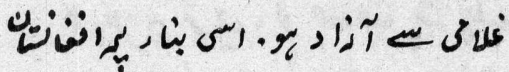

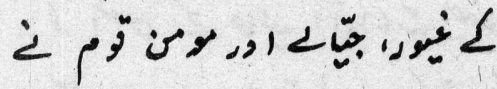

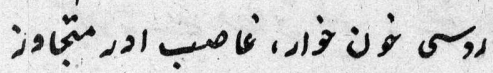
رو

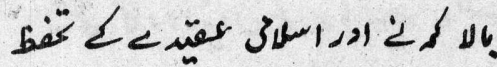
ك هانَّ لاغ 品

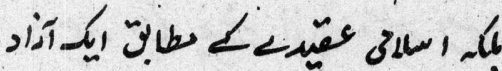

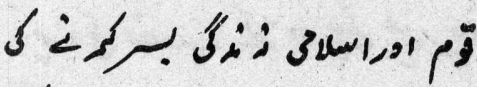
، ضَّ :

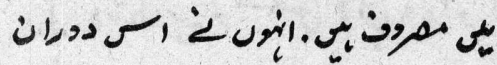

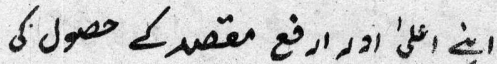

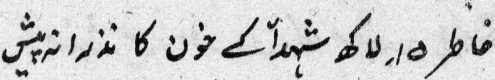

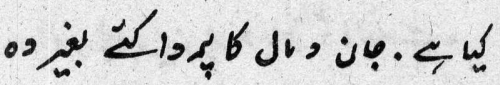

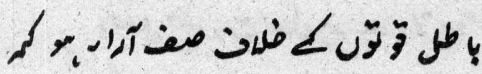
ك اهم ل

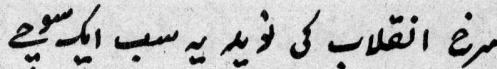

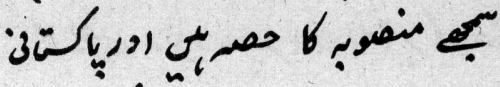

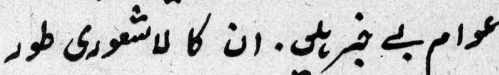

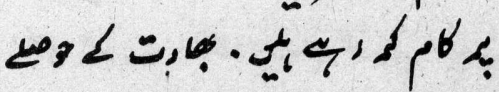

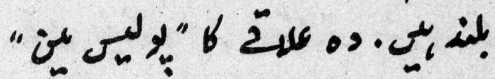

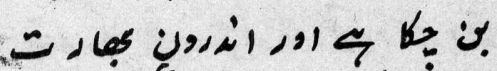

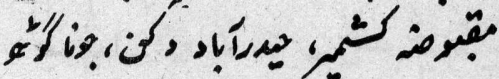

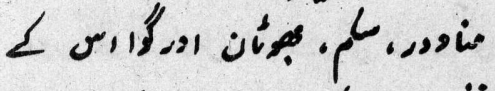

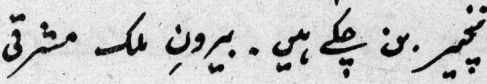

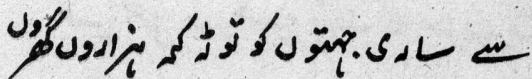

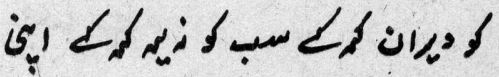

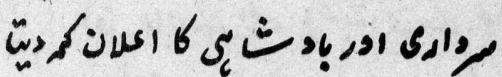

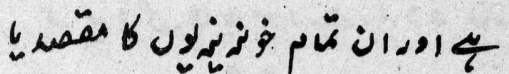

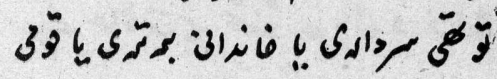

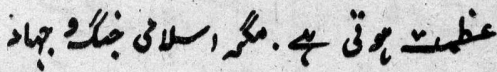

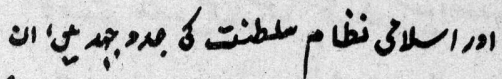

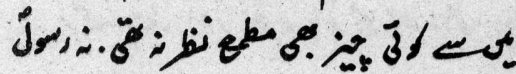

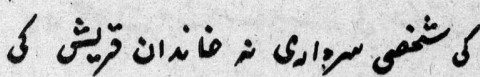

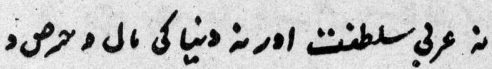

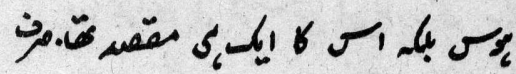

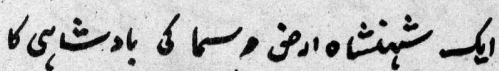

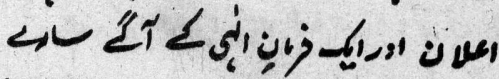

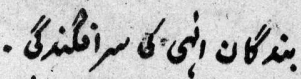

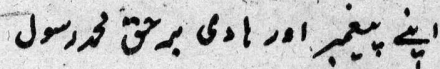

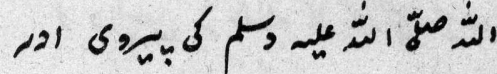

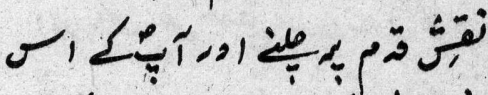

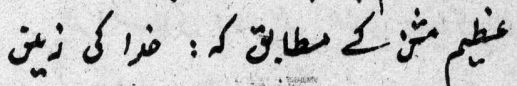

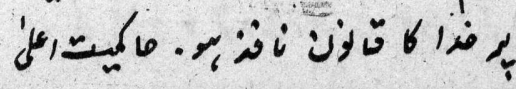


rr

Ca

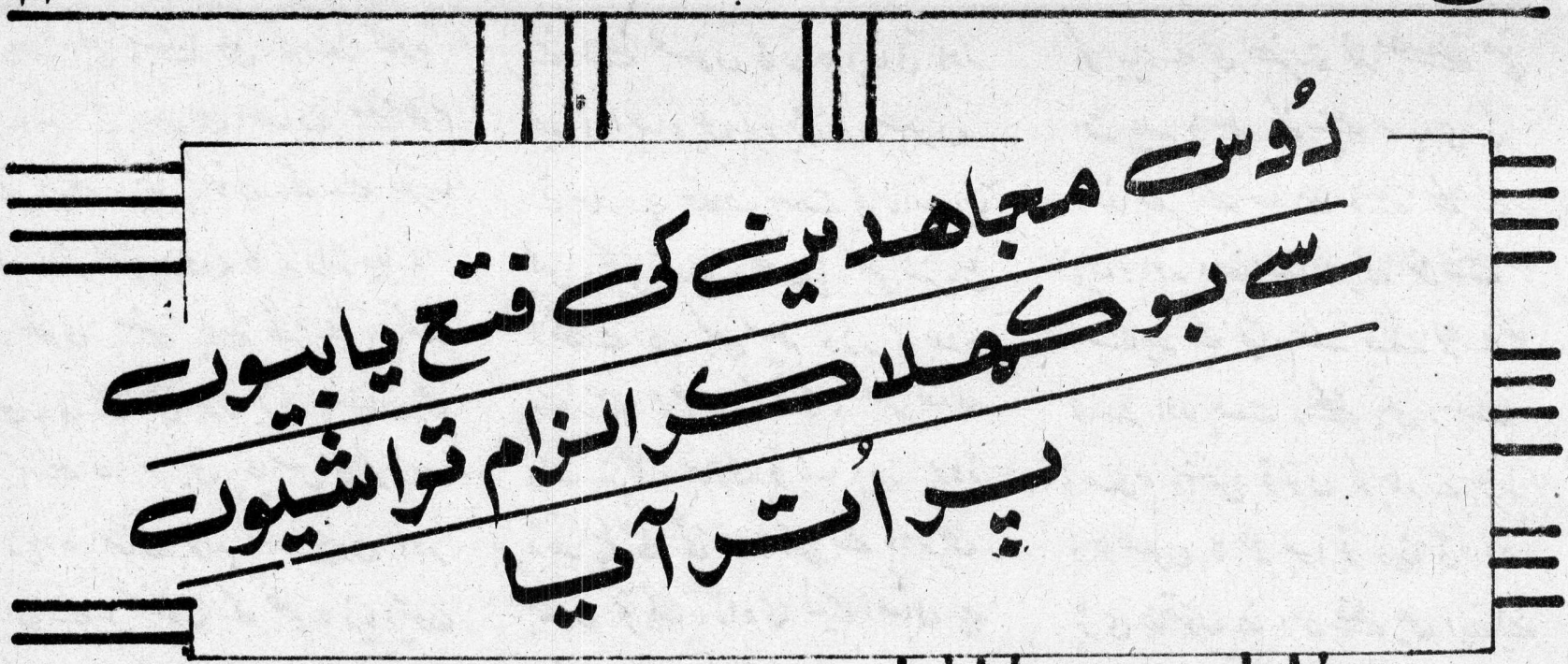

定

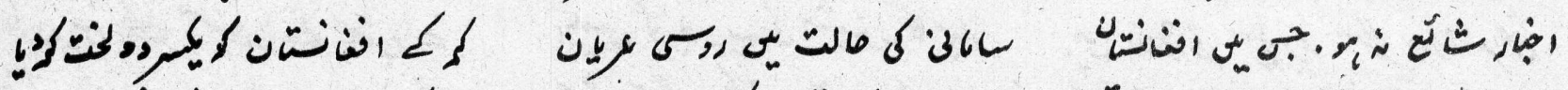

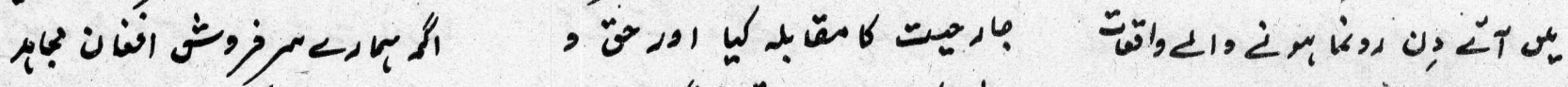

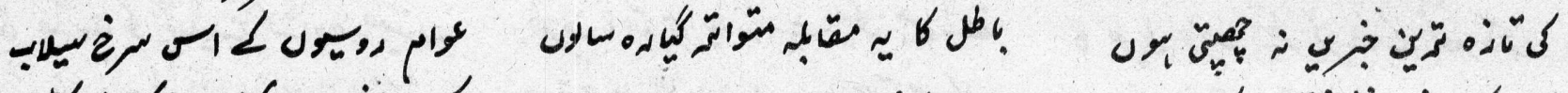

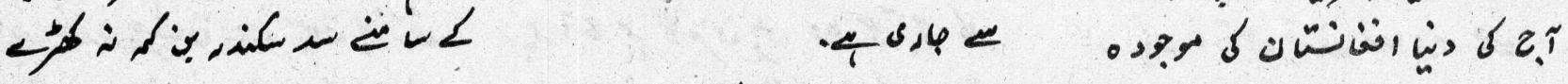

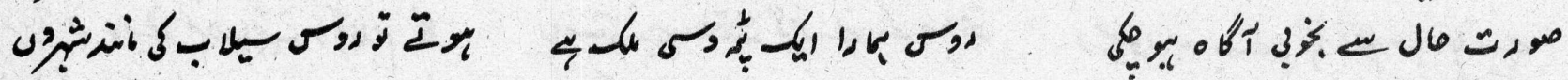
ب.

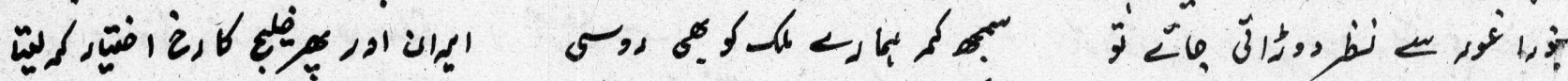

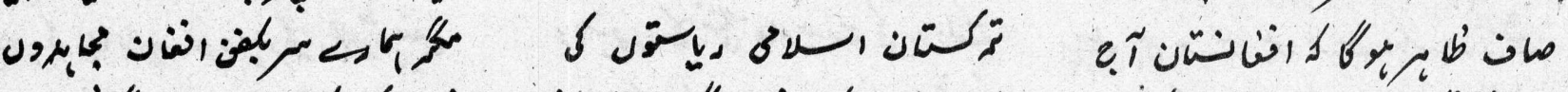

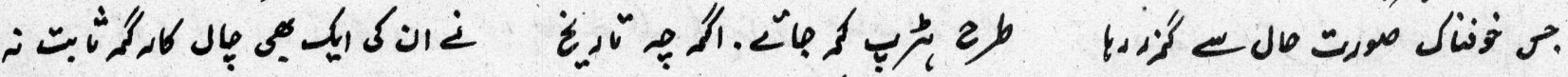
.

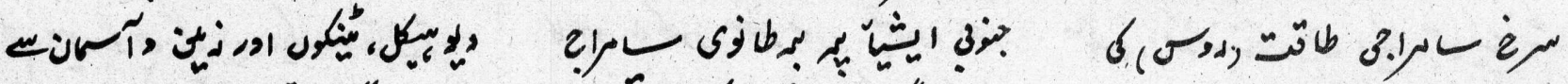

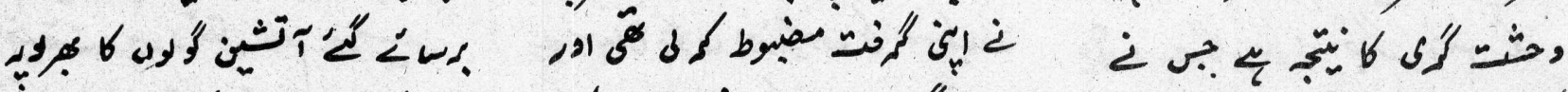

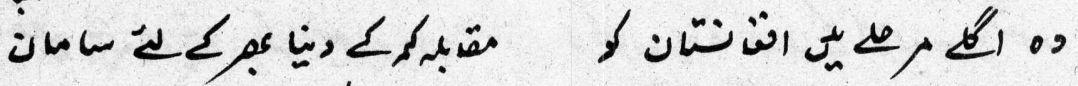

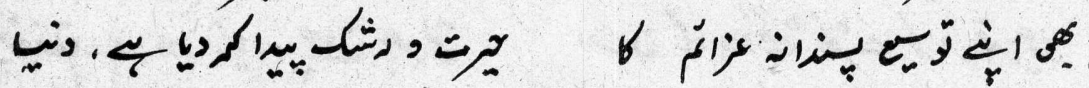

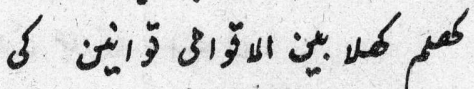

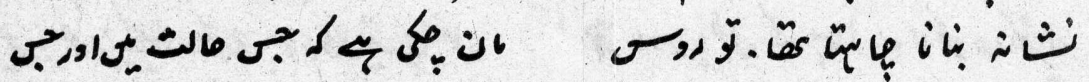

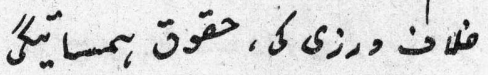

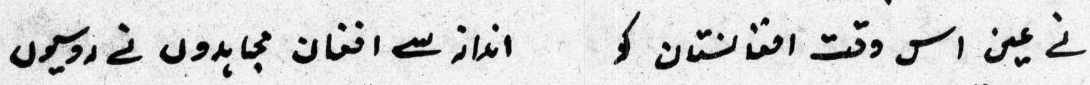
1

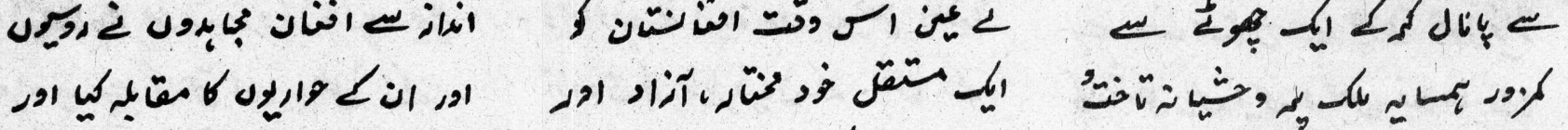

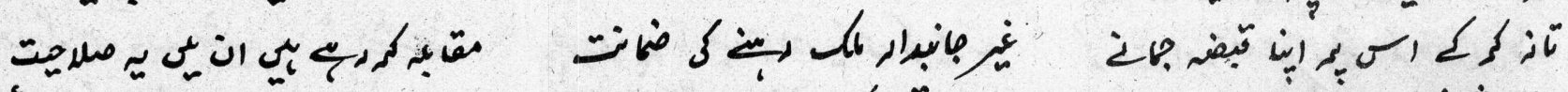

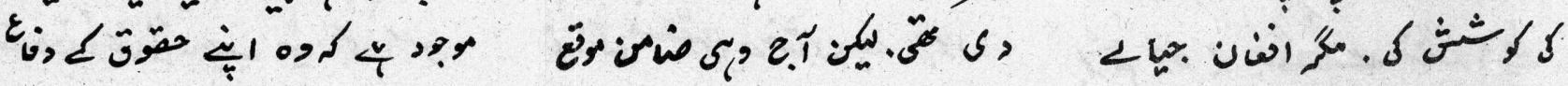

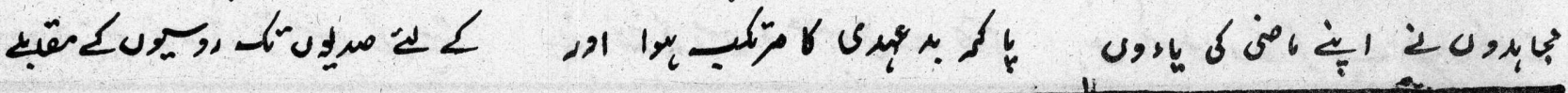




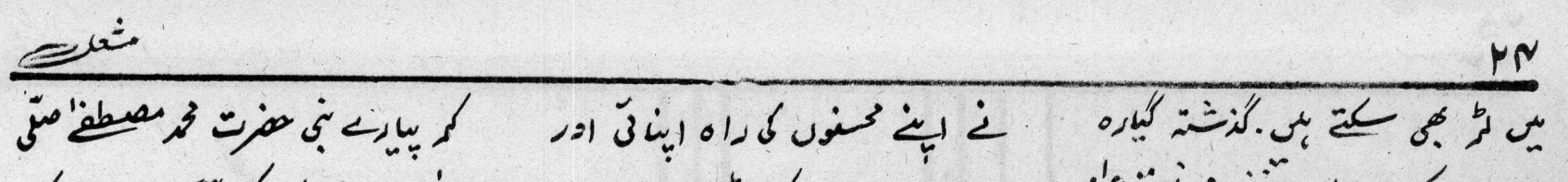

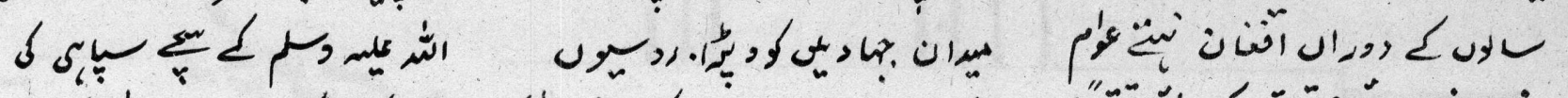

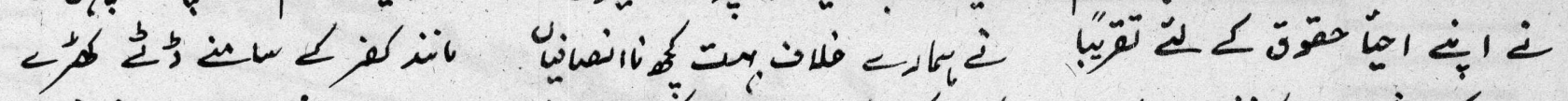

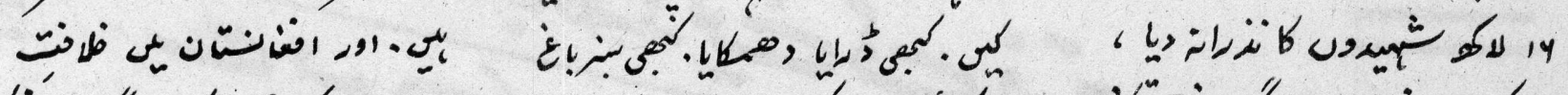

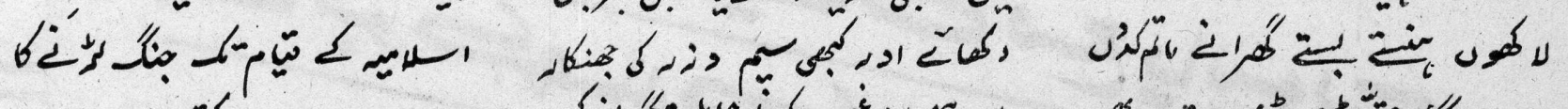

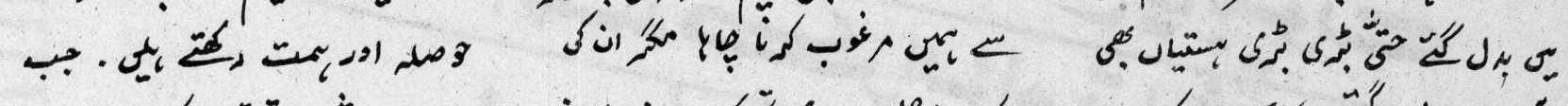

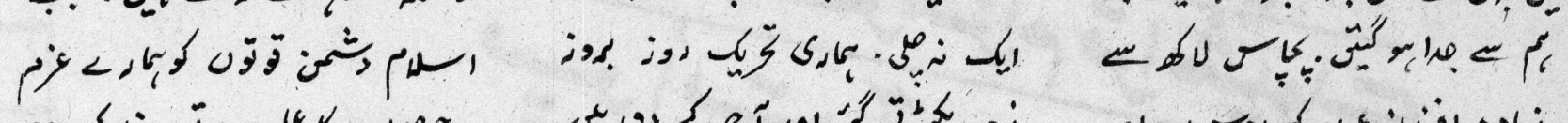

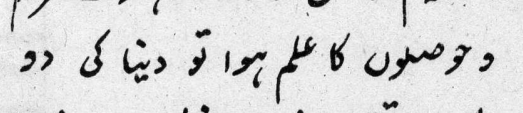

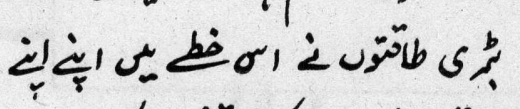
它

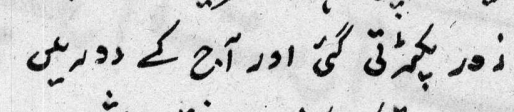

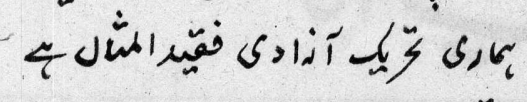

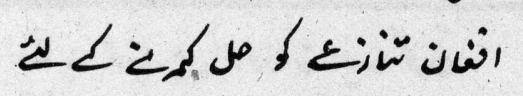

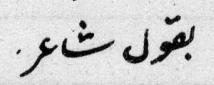

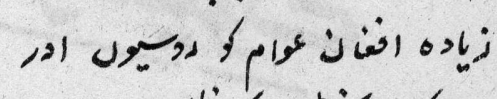

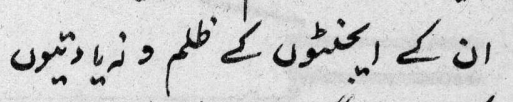

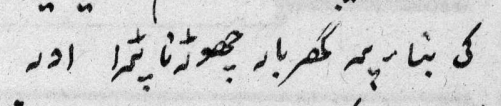
ن

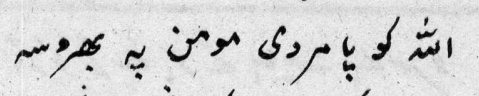
آن

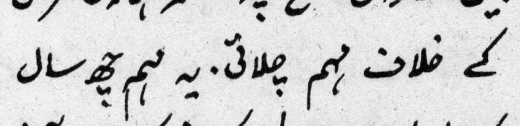

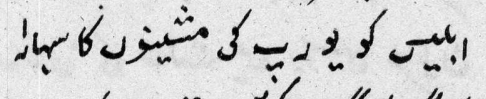
ट1/8 ن.

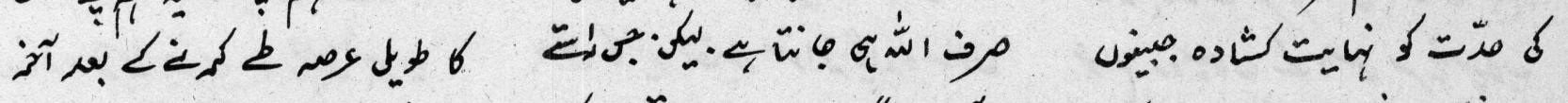

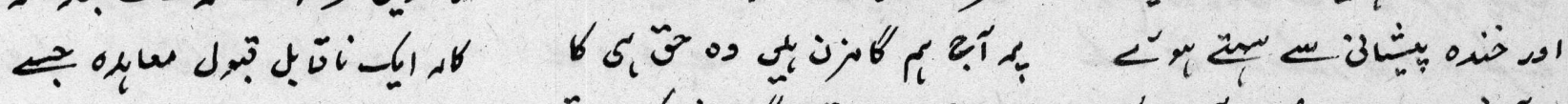

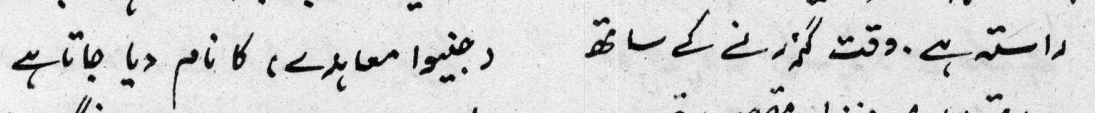

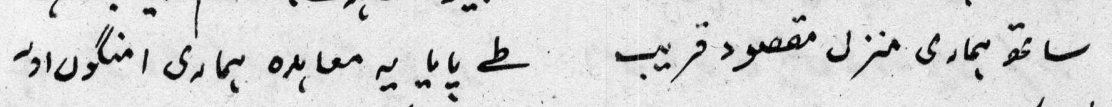

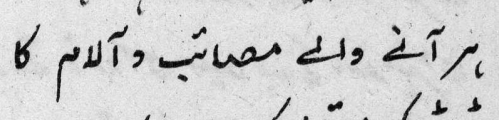
-

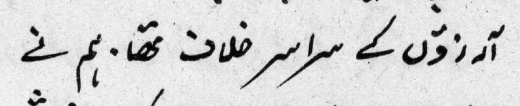

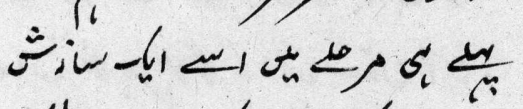
;

14

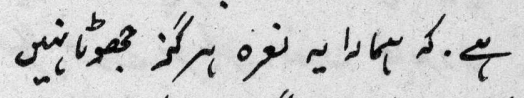

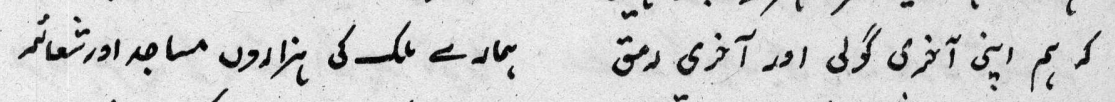

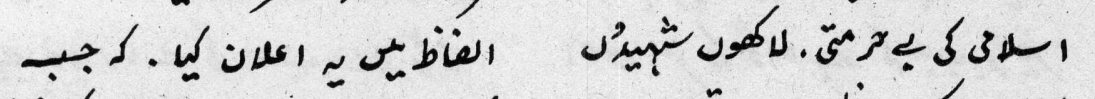

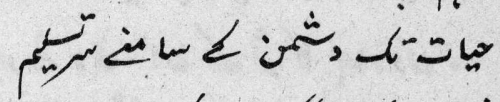

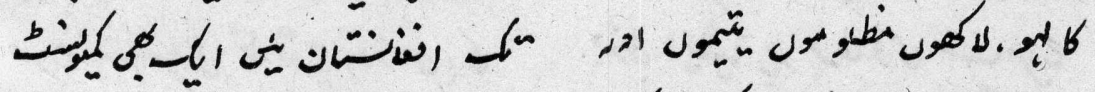
药 定

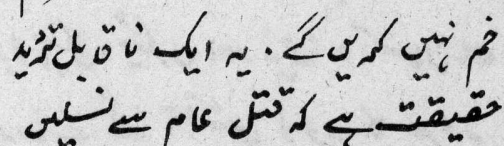
فان بارى

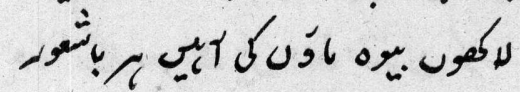

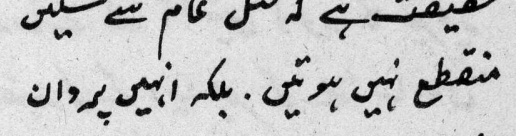

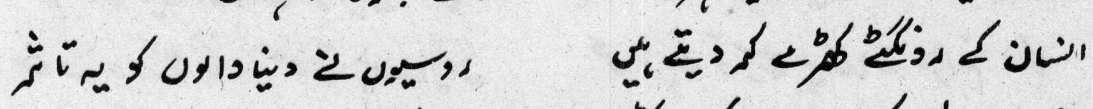

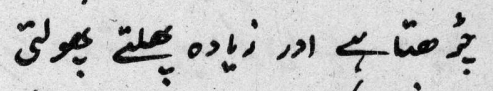

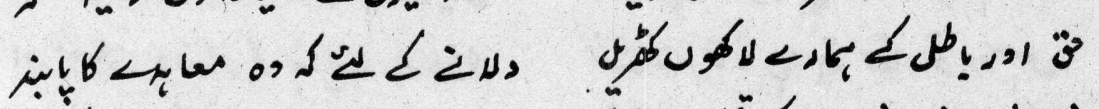

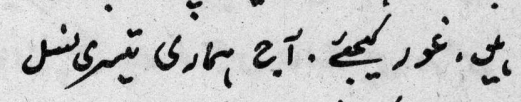

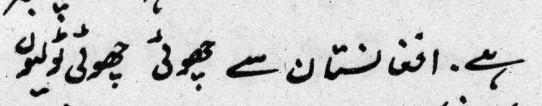
ك

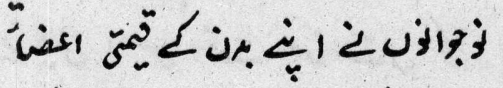

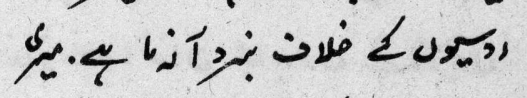
كآ

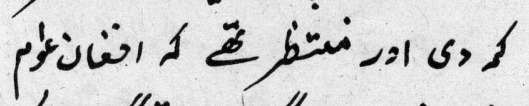
:

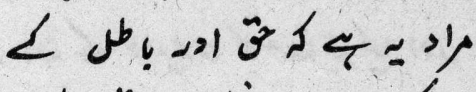
ट

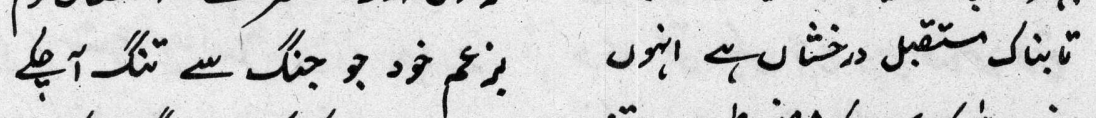

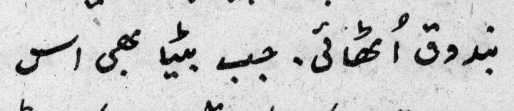

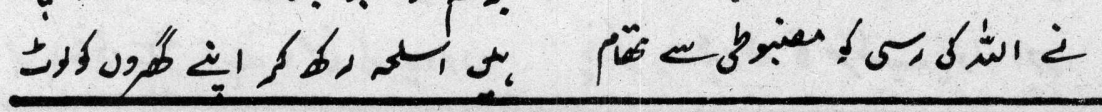

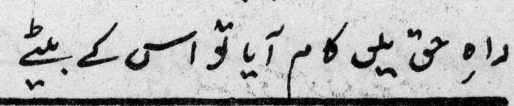




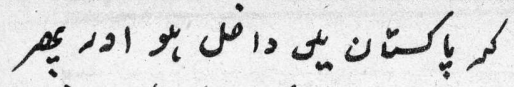

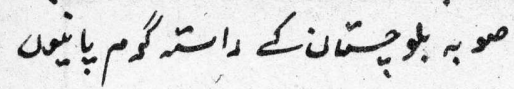

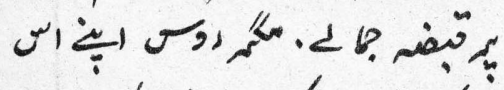

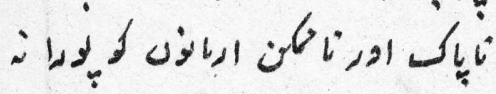

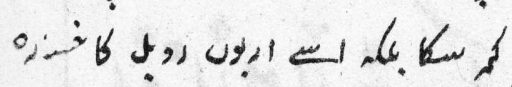
?

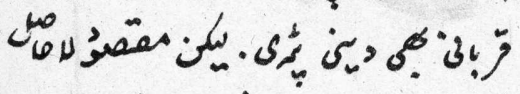

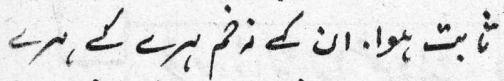

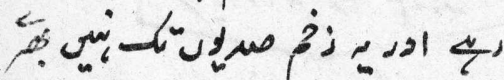

$$
\text { . } 40
$$

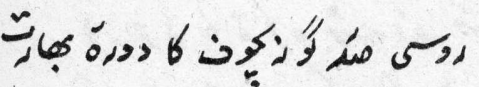

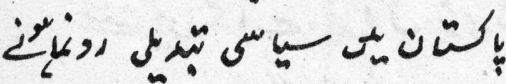

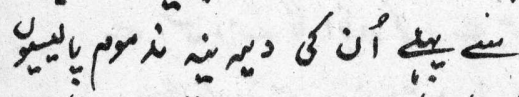
كا

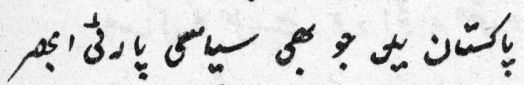

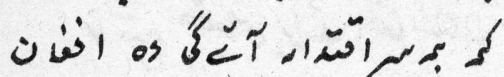

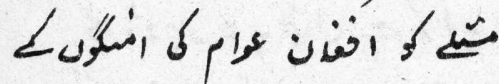

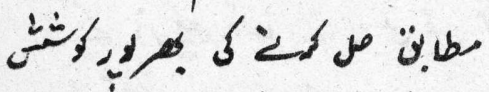

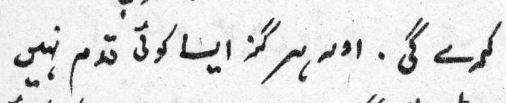

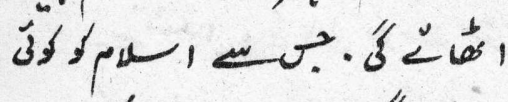
1 范

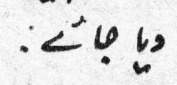

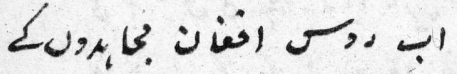

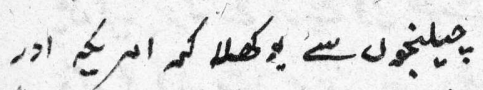

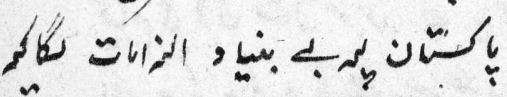
أن

$$
\text { بمّرل }
$$

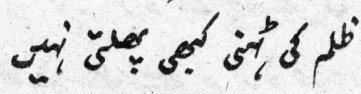
i
ओ ن ن

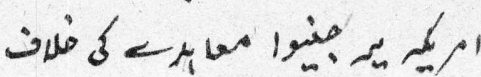

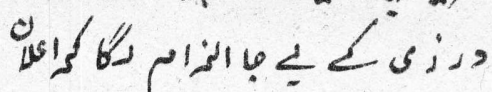
ك

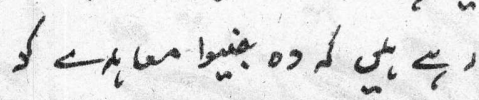

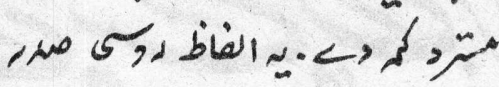

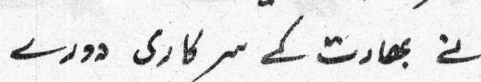
-

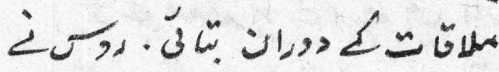
أبحا إس لذإن

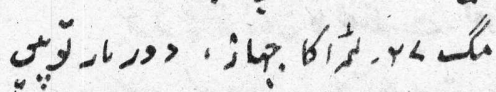

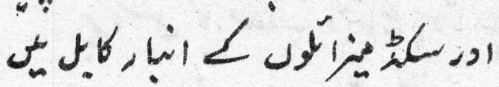

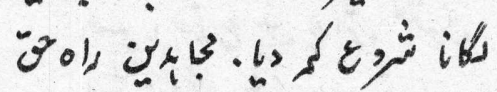

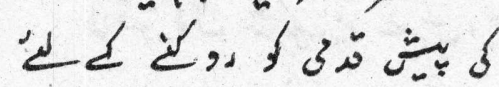
لئ

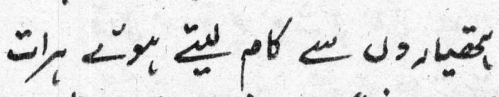

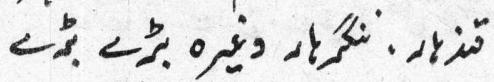

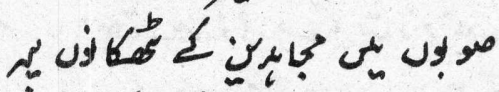

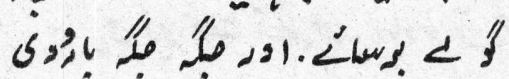

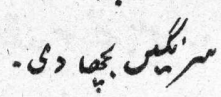

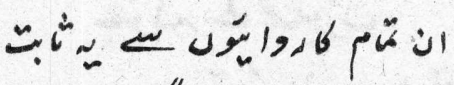

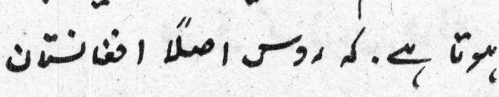

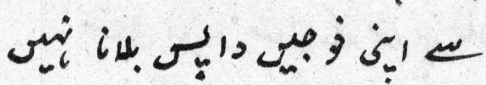

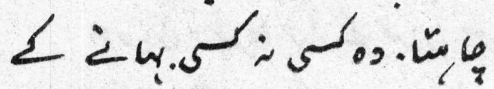

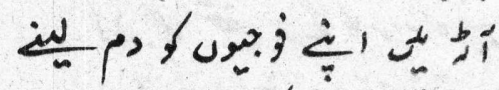

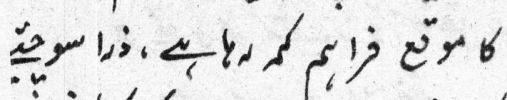

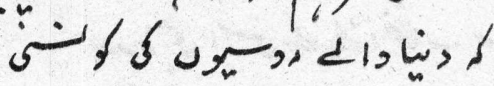

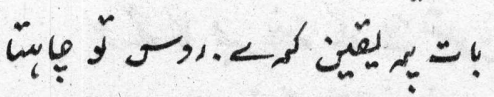

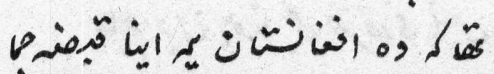

o. Jis

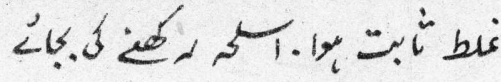

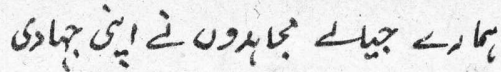
(i)

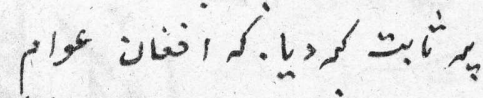

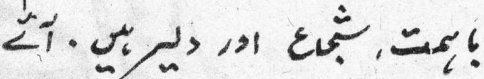

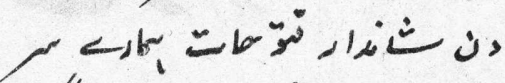

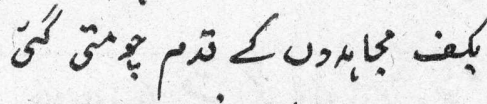

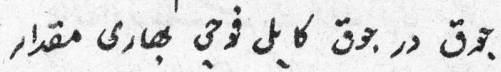

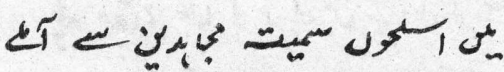

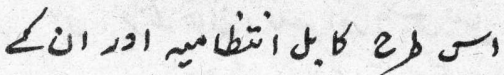

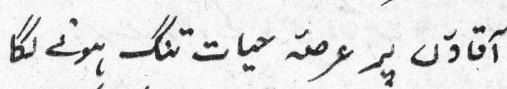

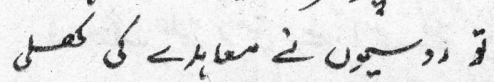

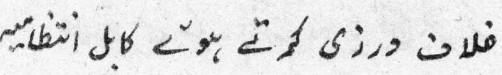
is

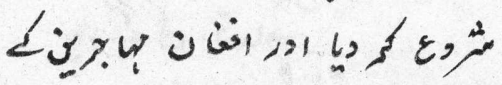

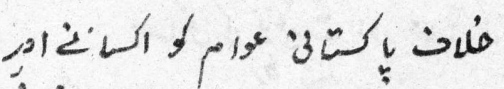
كهم

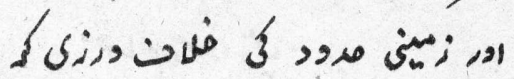
L

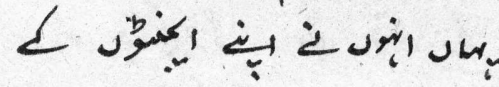
य 范

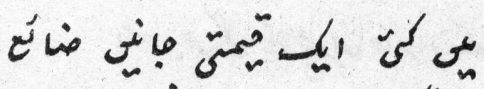

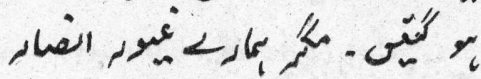

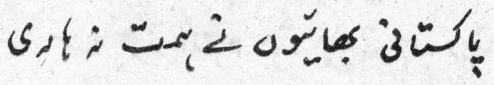

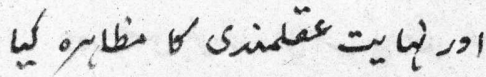

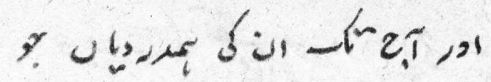

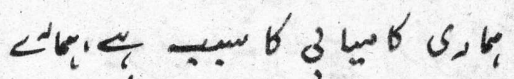

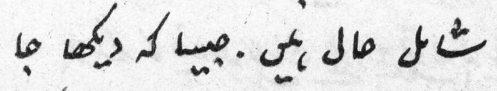
进范 
$=0 *$

PY

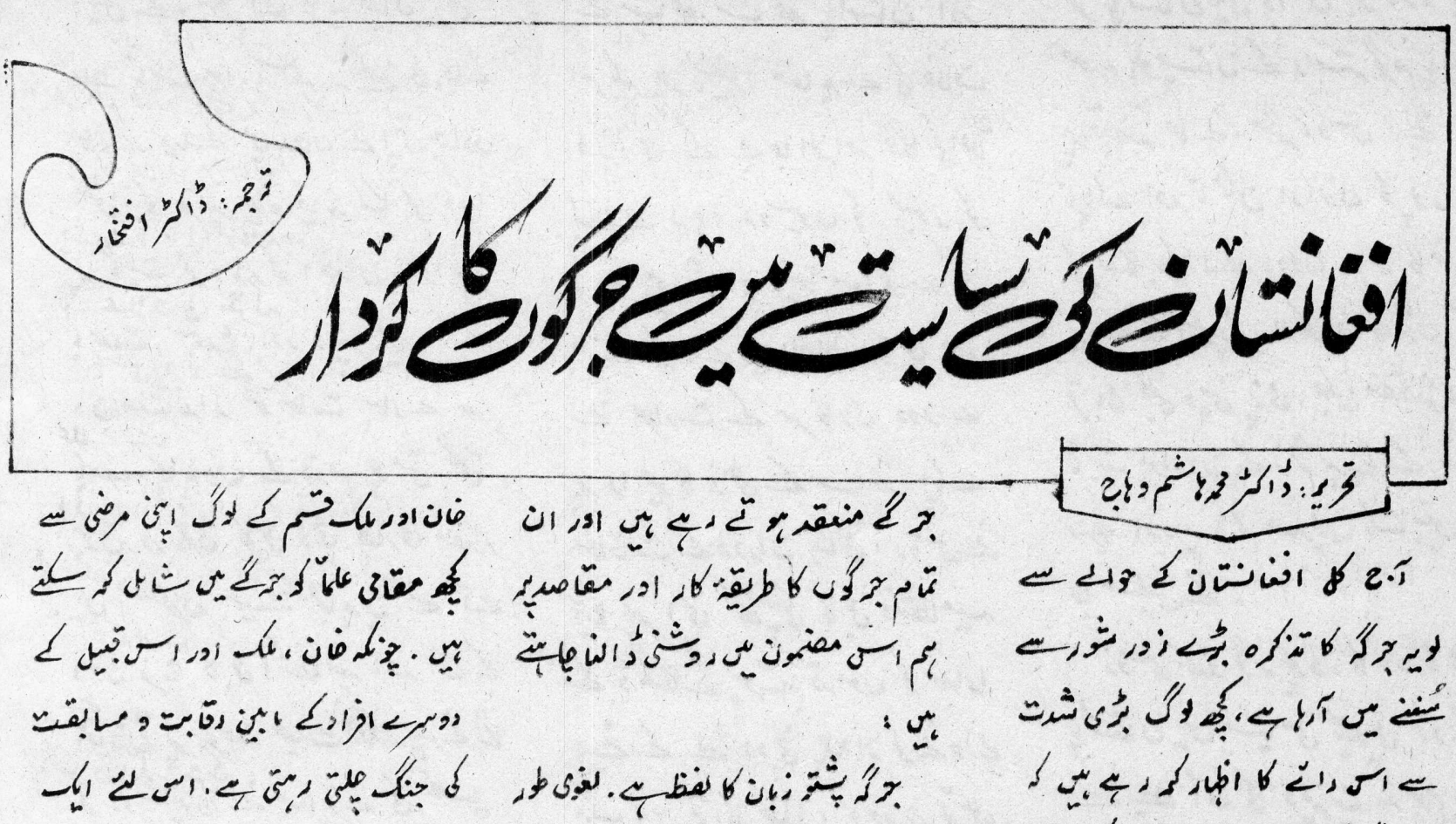

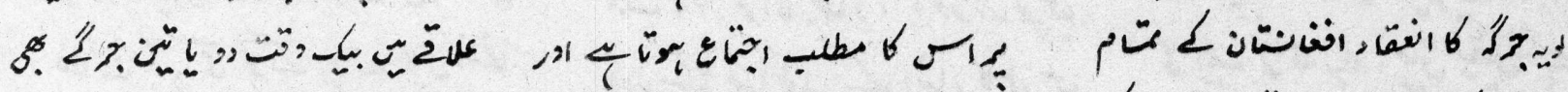

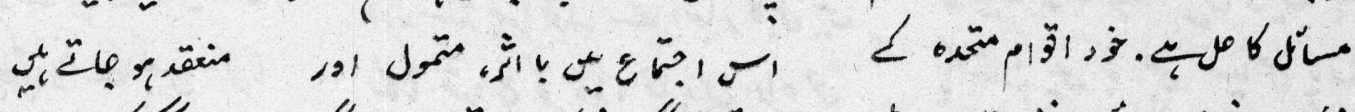

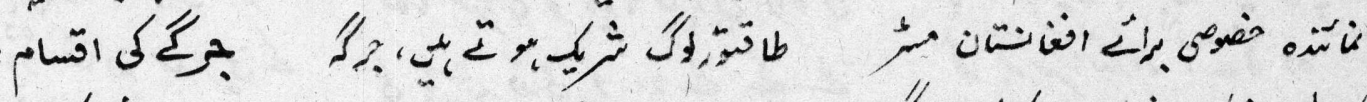

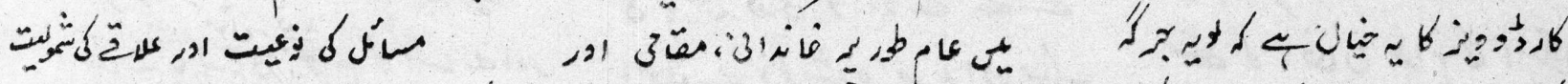

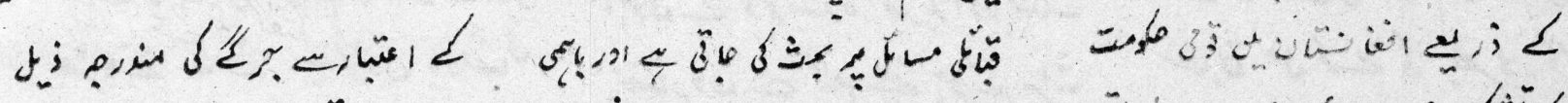

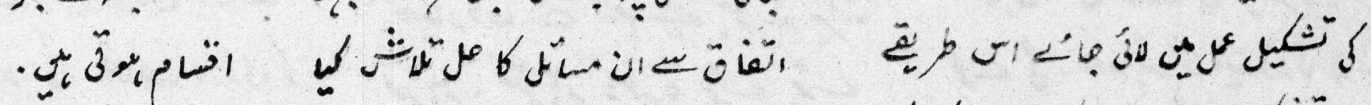

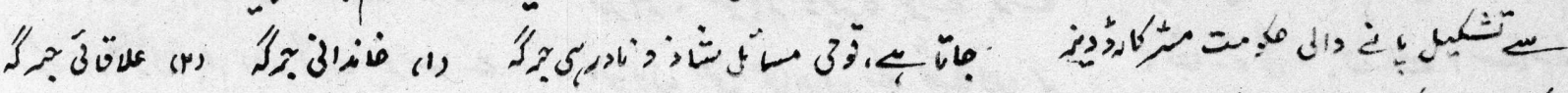

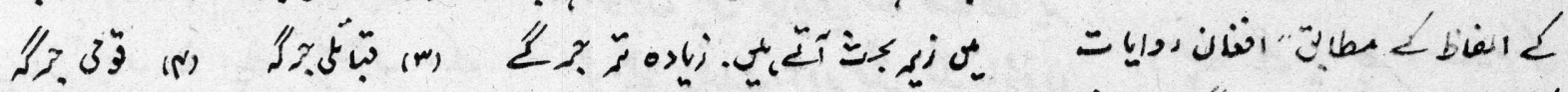

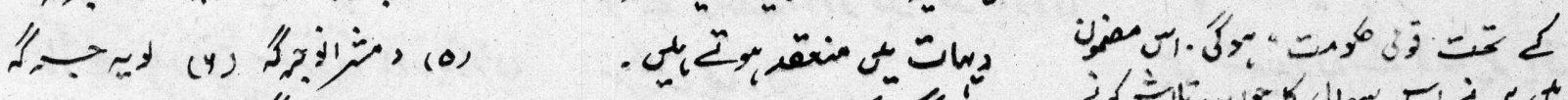

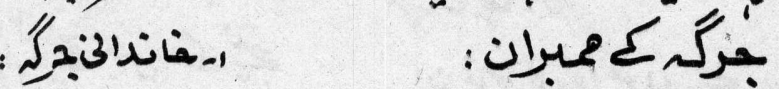

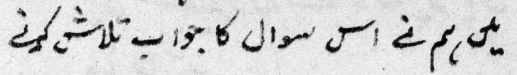
ن

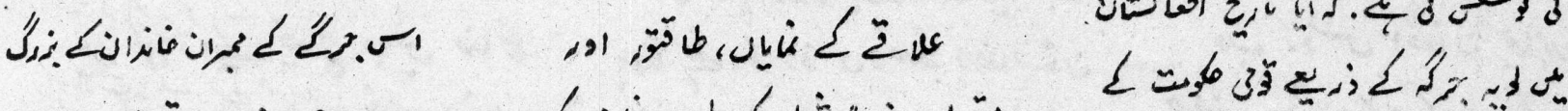

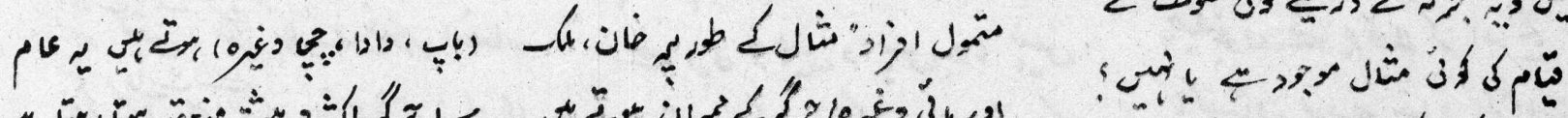

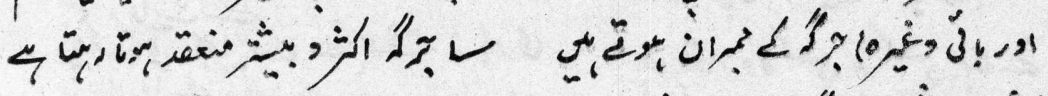

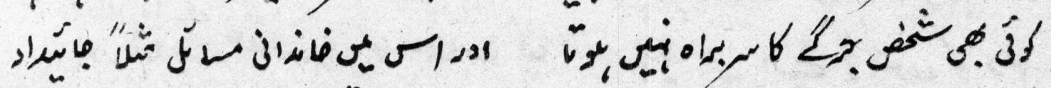
若

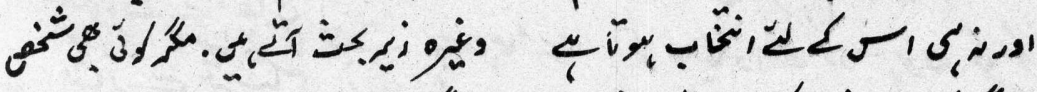

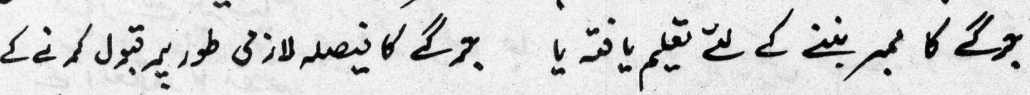

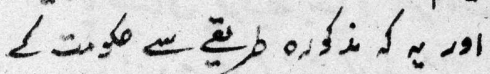
i) ؟

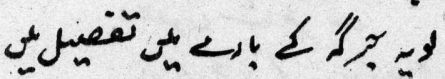

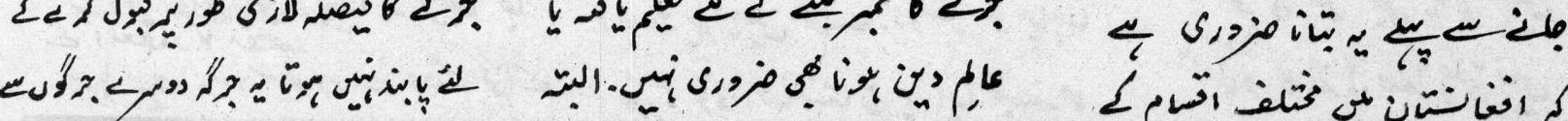

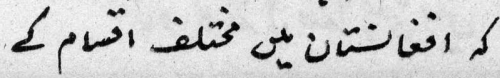


re

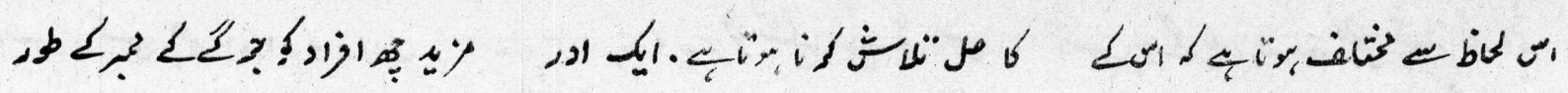

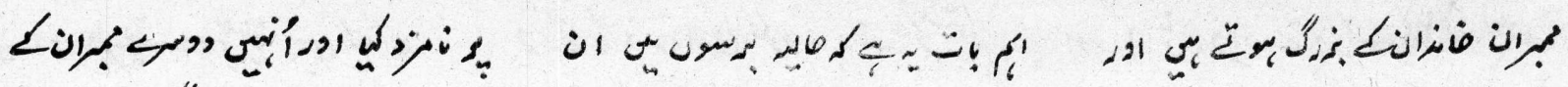

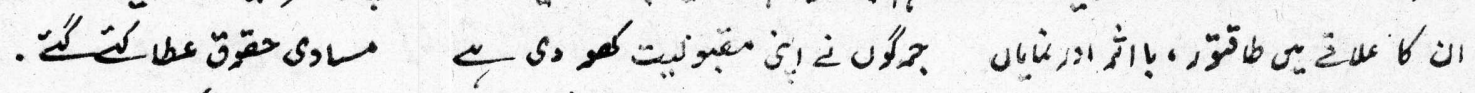

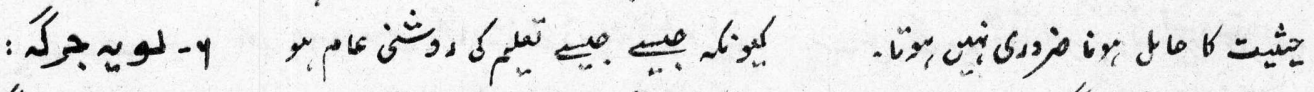

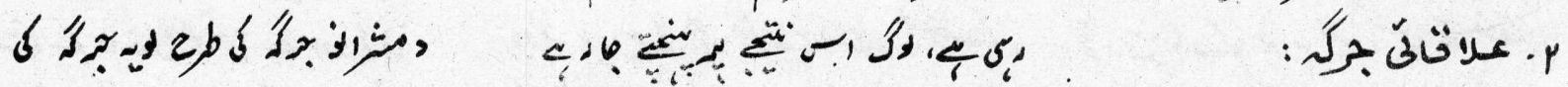

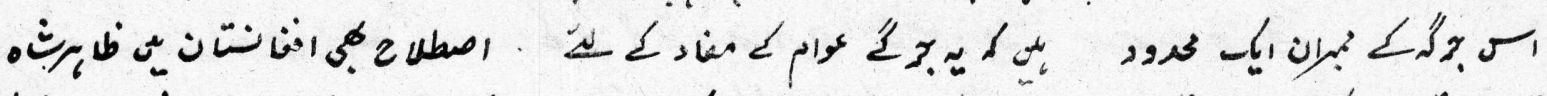

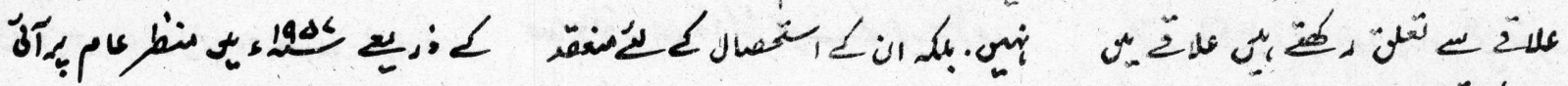

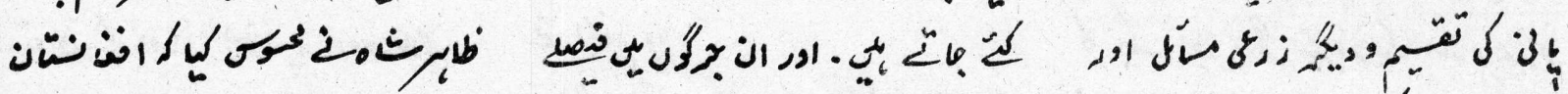

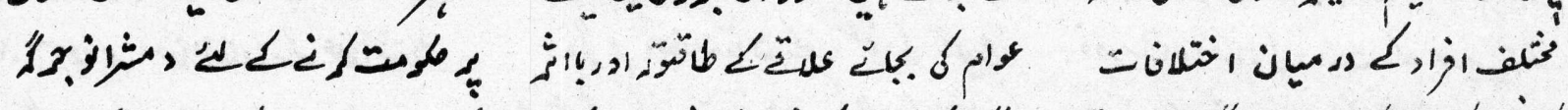

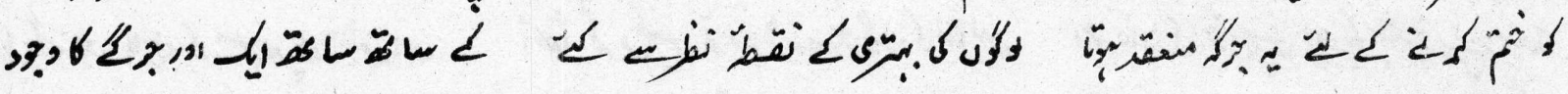

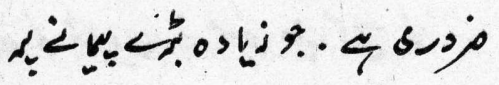
ب بـ آني

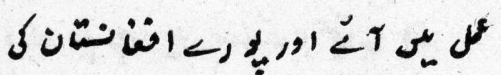

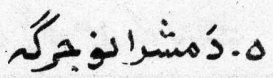

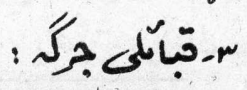

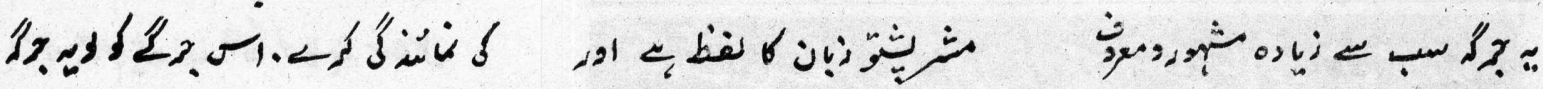

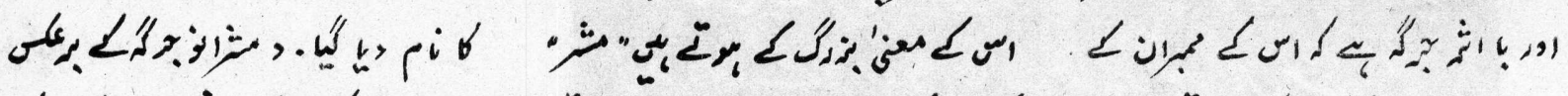

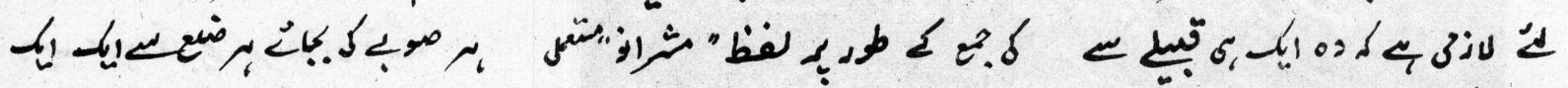

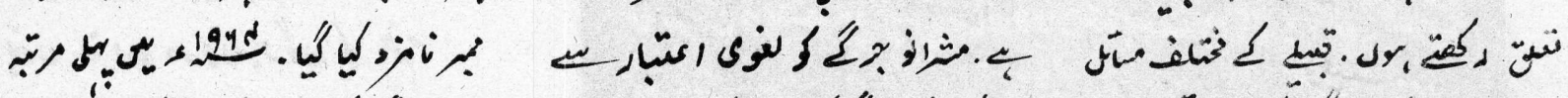

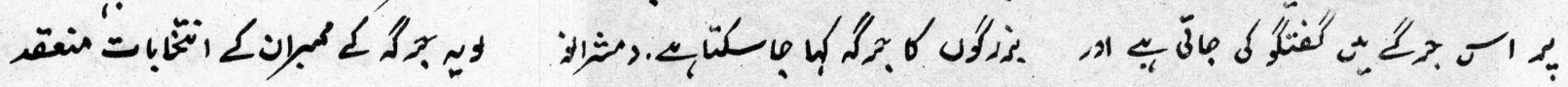

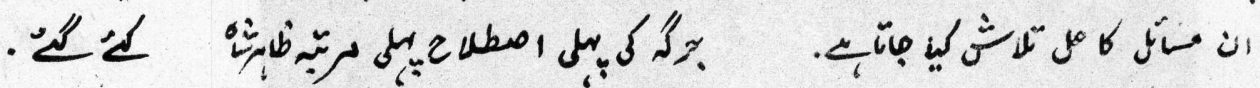

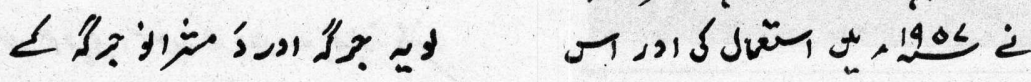

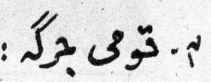

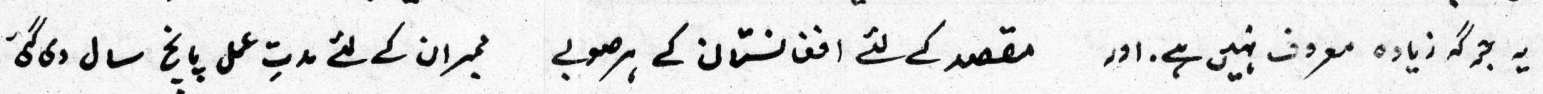

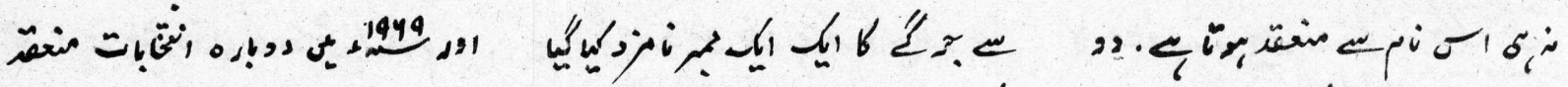
؛

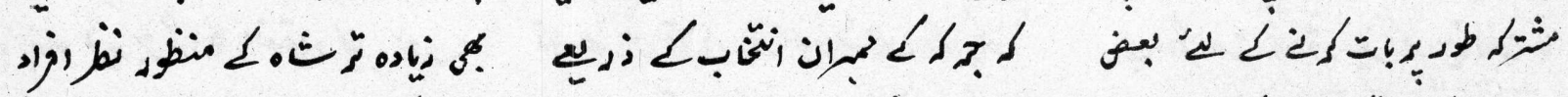

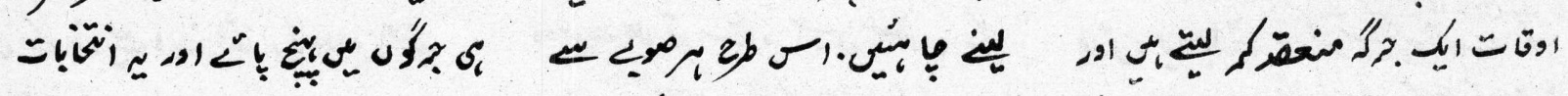

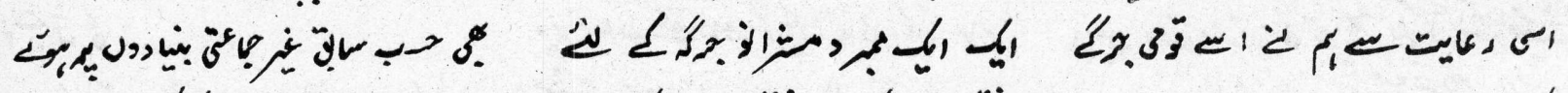

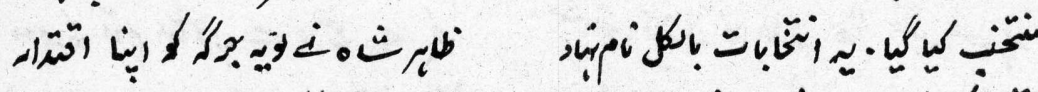
- 4 in

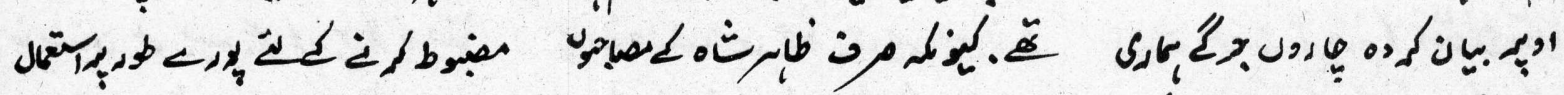

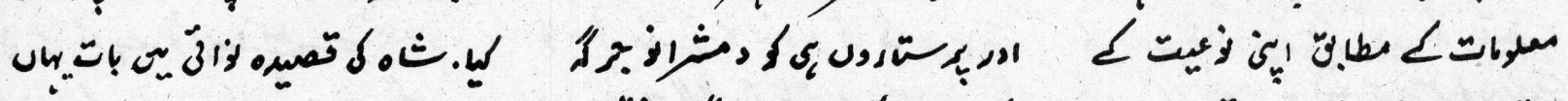

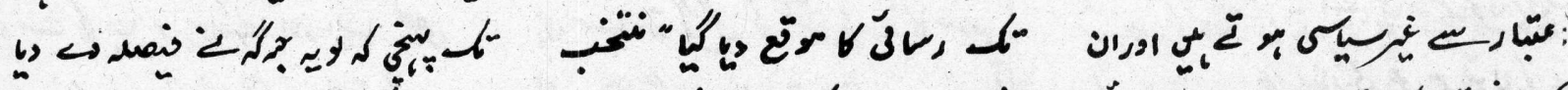

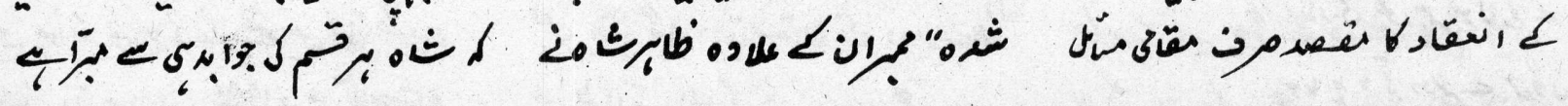




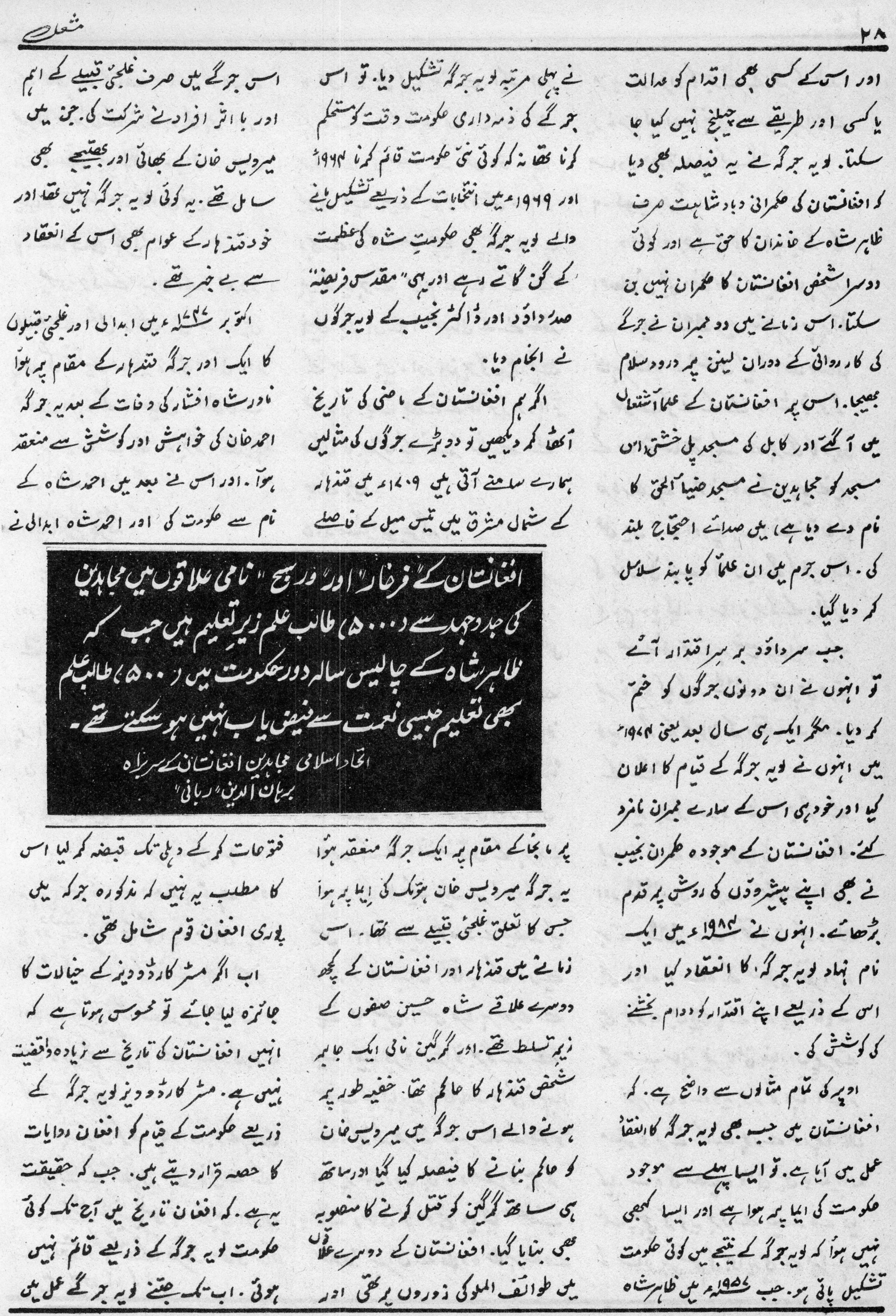




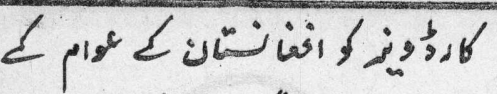
"

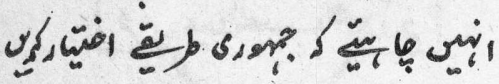

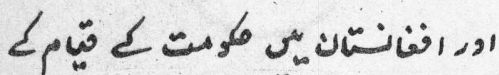
نेوند بك

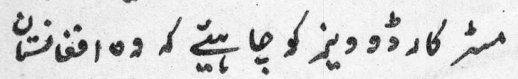

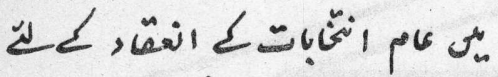
زيو

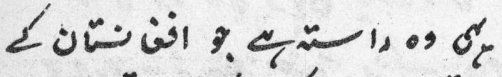

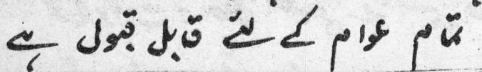

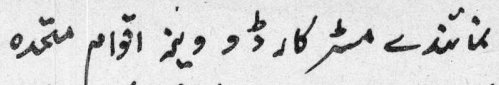
L ن

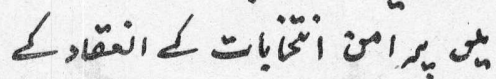
؟

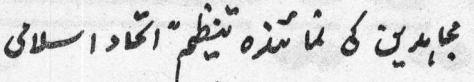

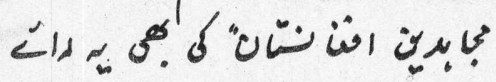

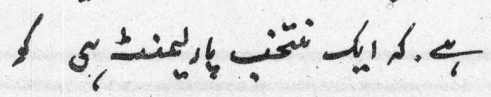

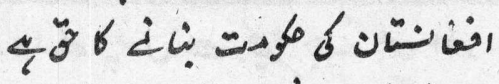

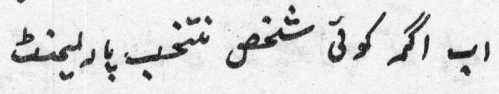

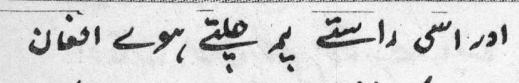

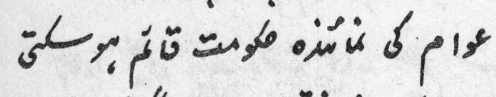
ك.

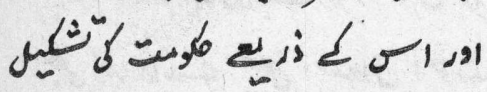

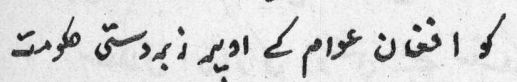
W :

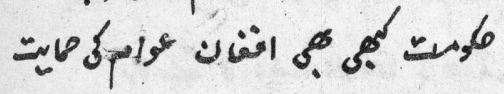
.

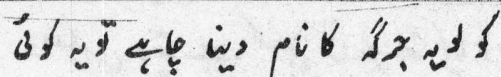

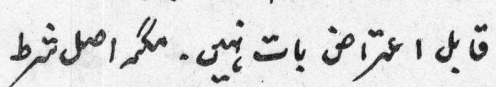

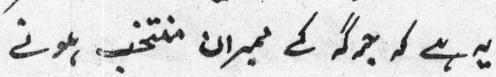
-

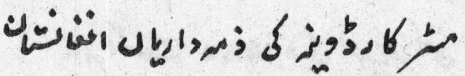

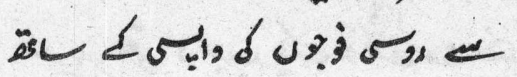

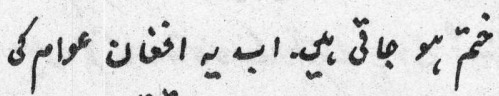

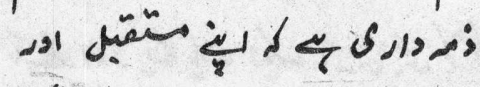

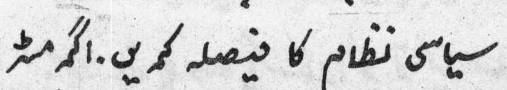

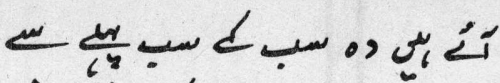
范

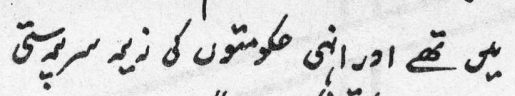

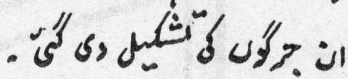

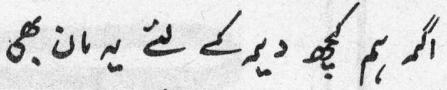
له

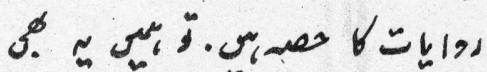

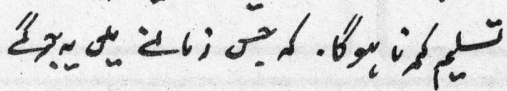

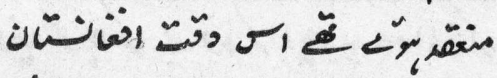

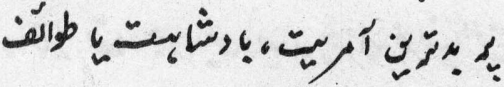

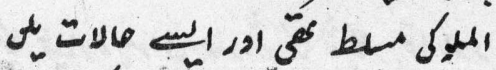

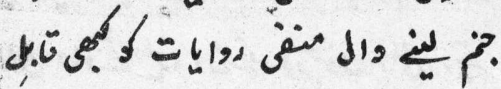

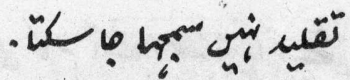

-

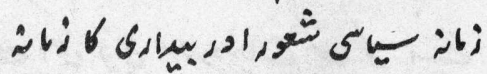
ن 它 حقوّة

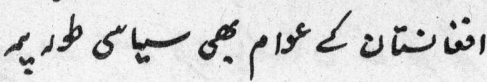

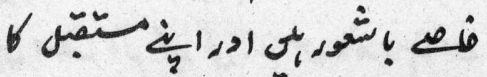

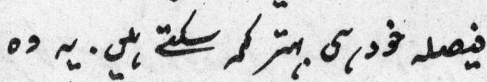

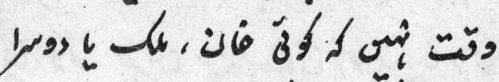

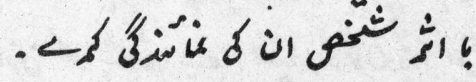

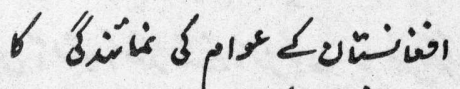

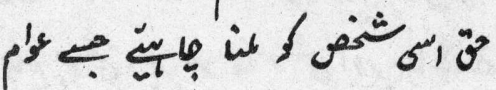
. ا إنخا!

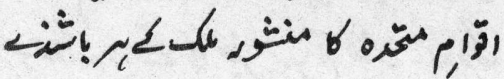

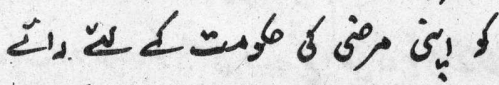

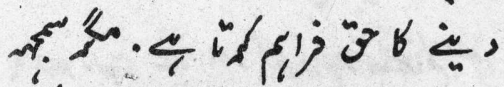

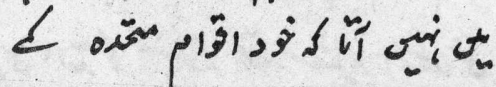




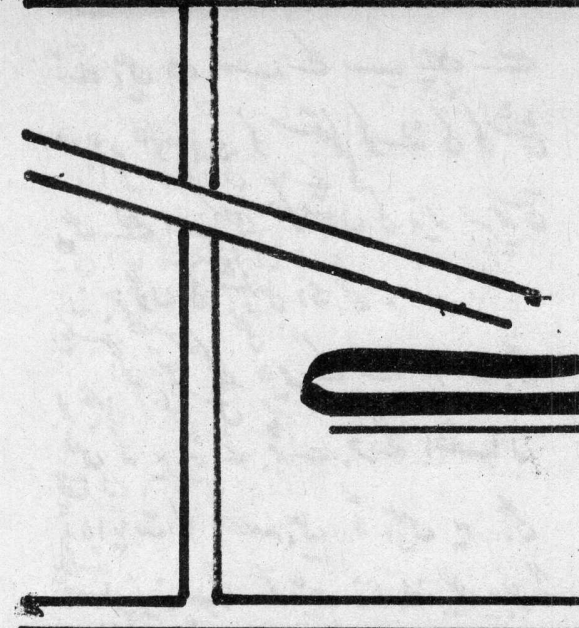

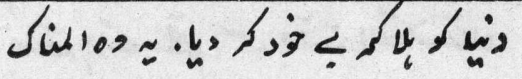

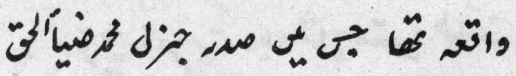

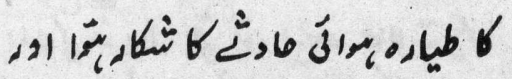

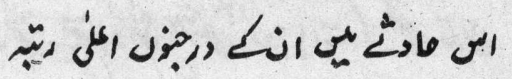
i

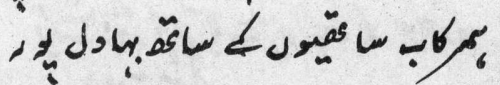
㻤

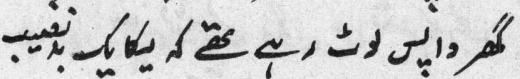

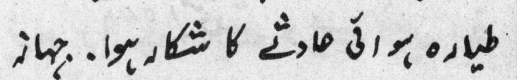

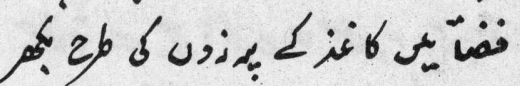

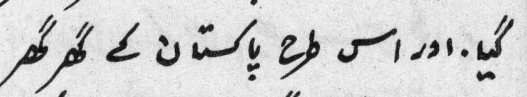

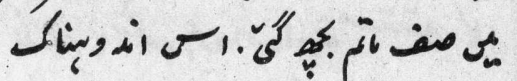
*

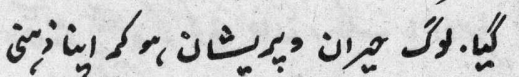

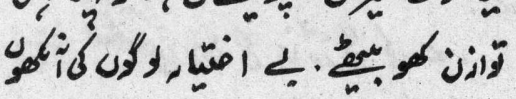

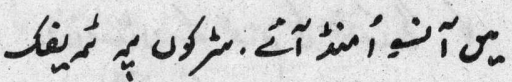
¿土टن

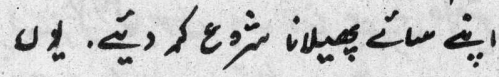

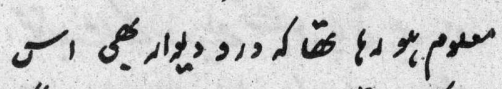

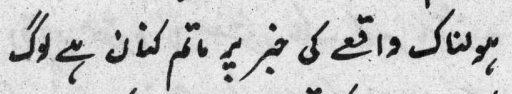

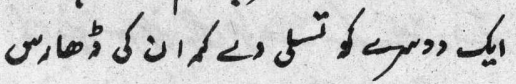

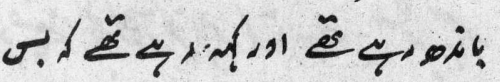
S 1,0 .
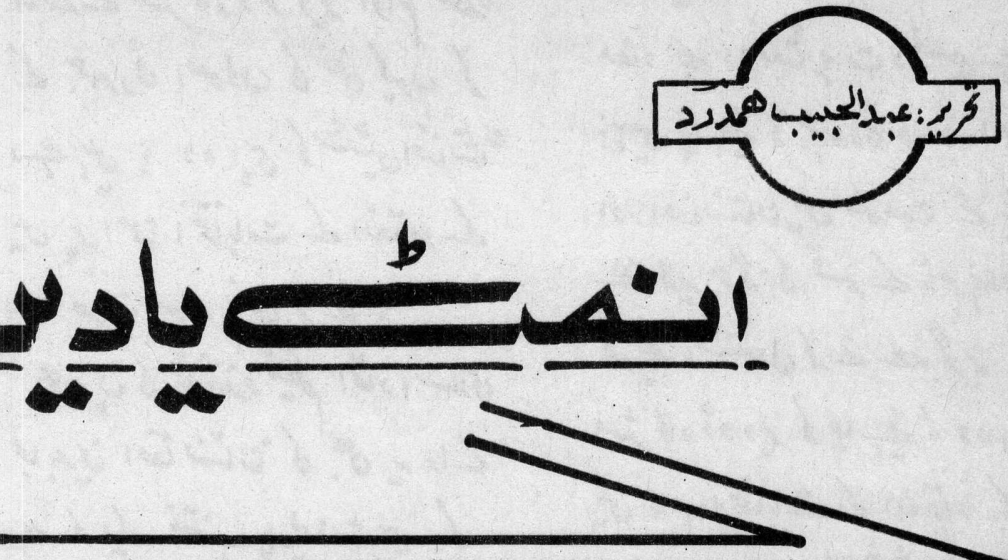

$121 \mathrm{U}^{4} 20$

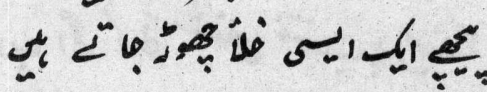
๘" Liا N1

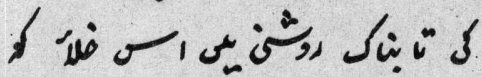
.

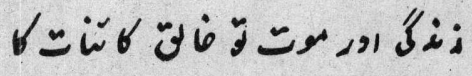

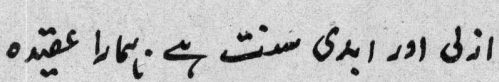

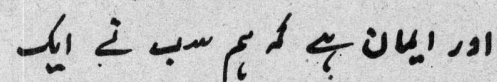

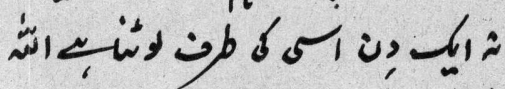

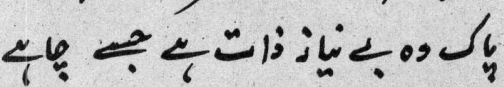

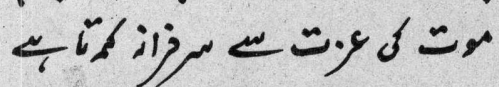
ڤ :

$$
\text { - } 44
$$

$\frac{6}{6} v i b=0$

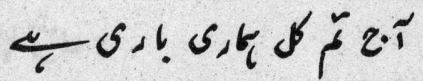

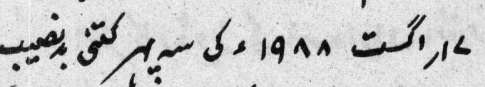

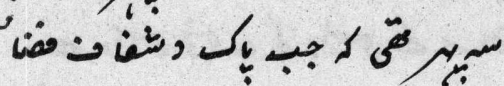

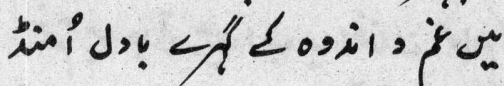

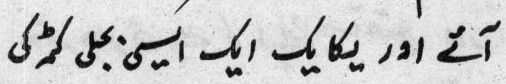

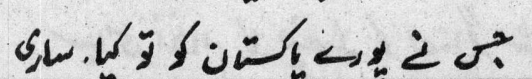

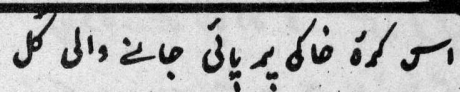
Si 5 م

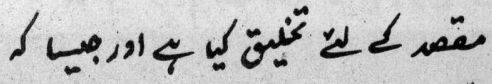

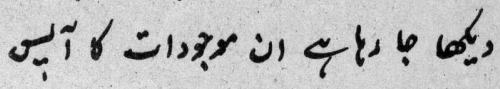
ए ? $5 \geqslant b_{i, 21}, 30$

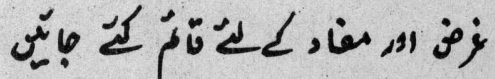
— i i ن

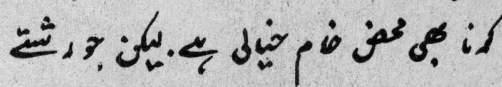

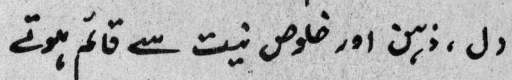

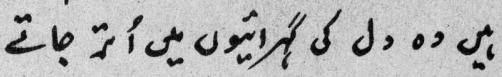
wis

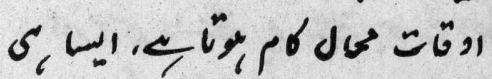

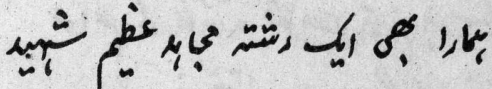

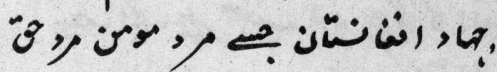
ك. liv

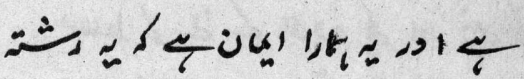

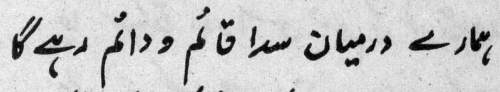

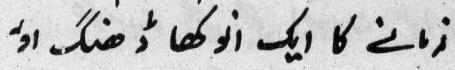

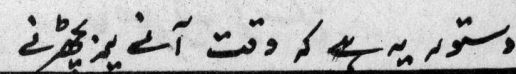


WI

el.

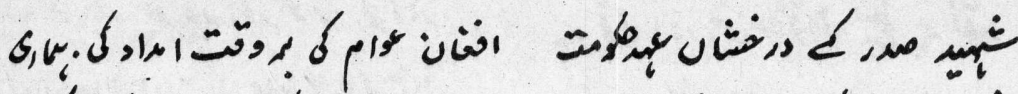

. ماءs

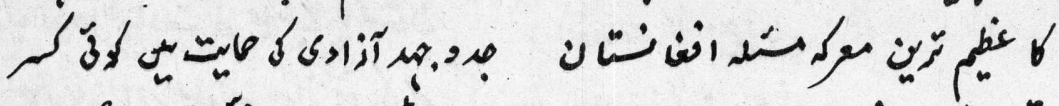

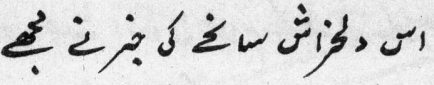

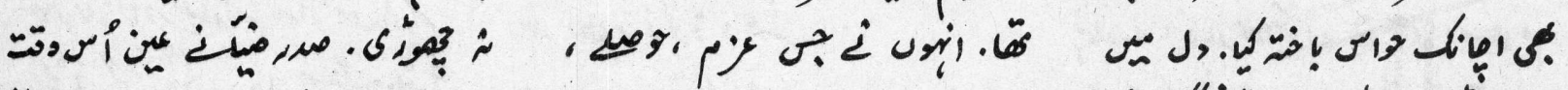

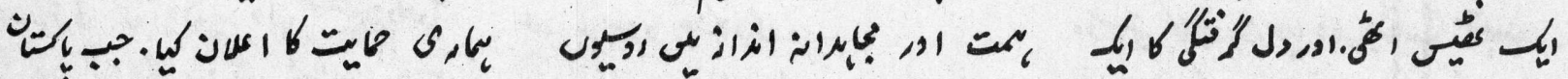

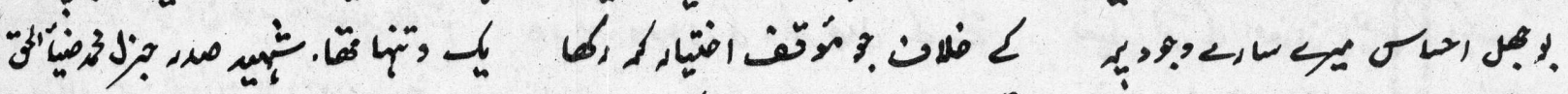

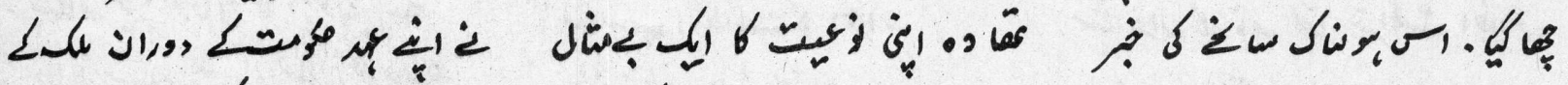

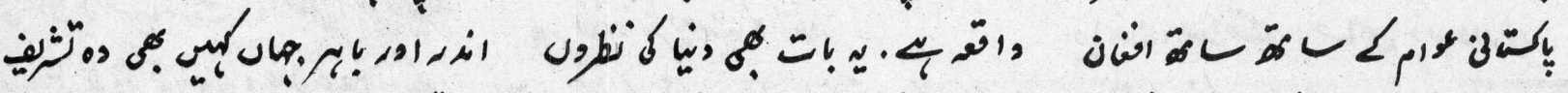

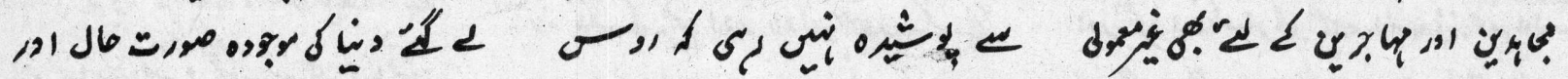

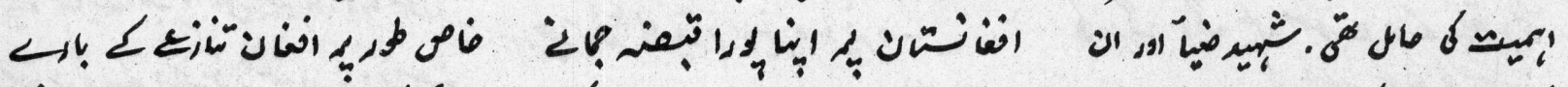

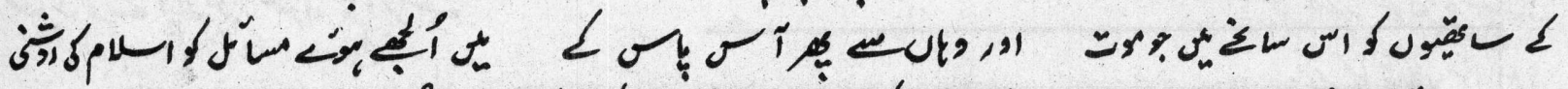

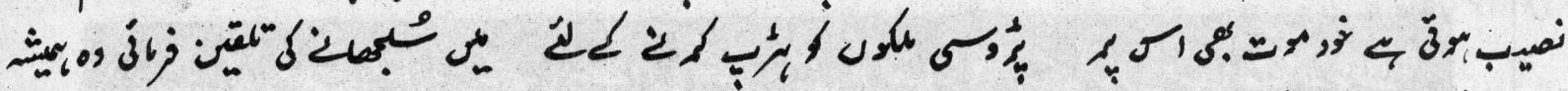

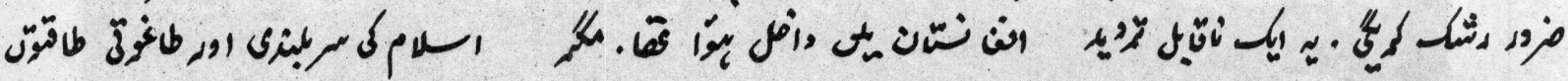

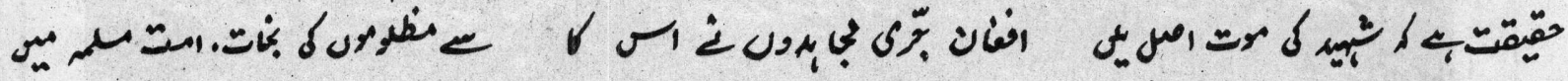

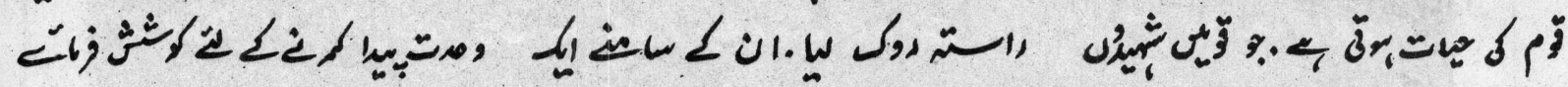

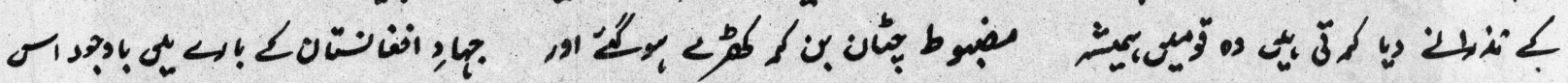

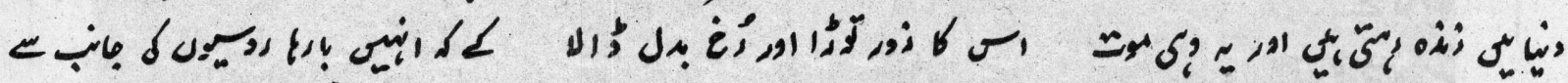

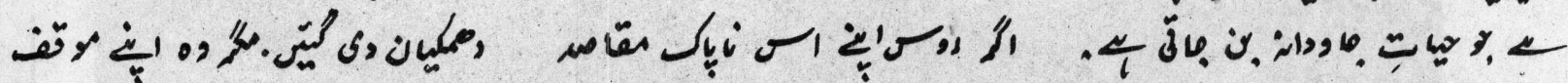

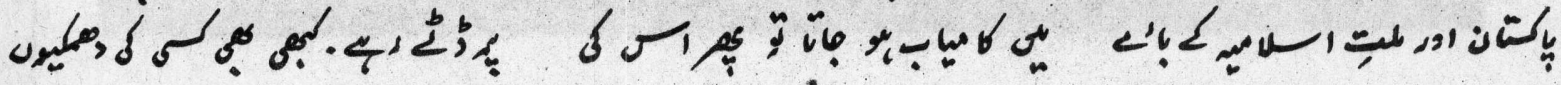

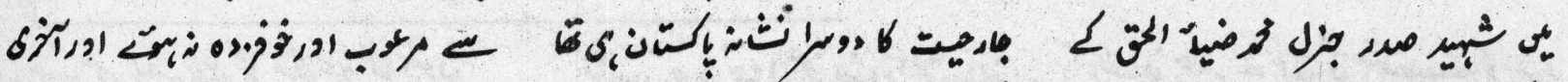

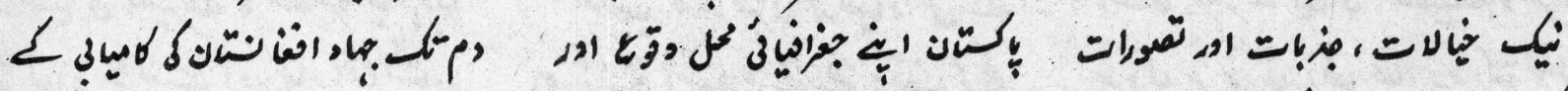

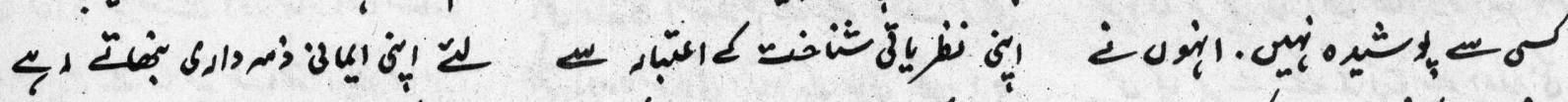

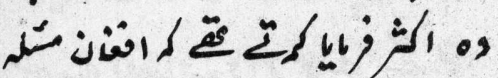

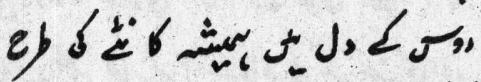
مأب

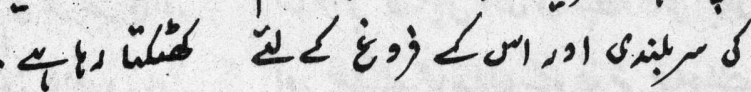

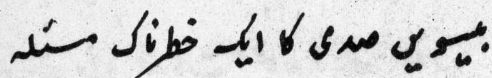
ث

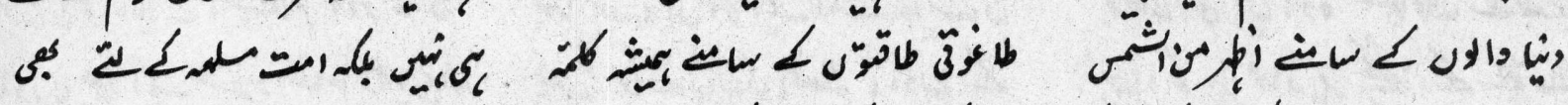

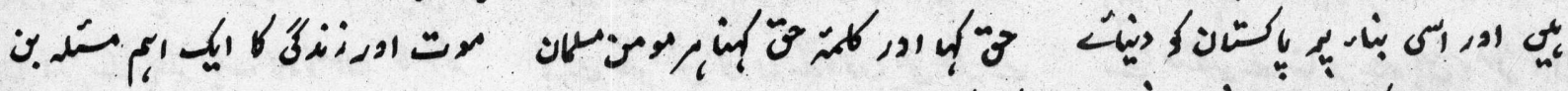

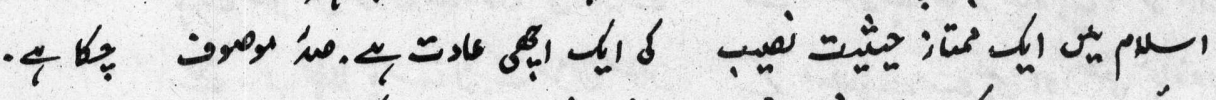

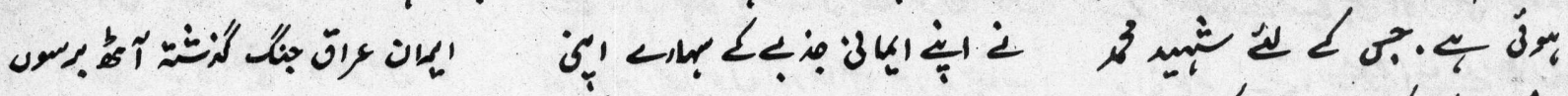

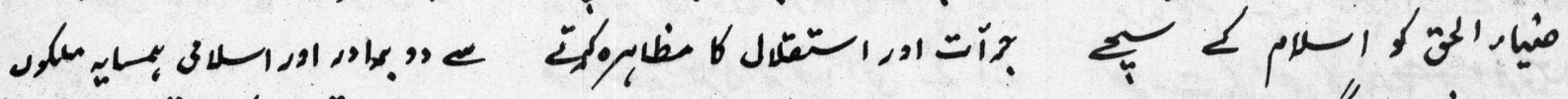
ت 
定

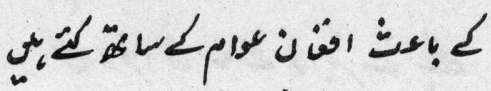

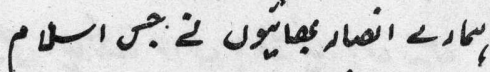

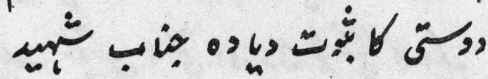
-

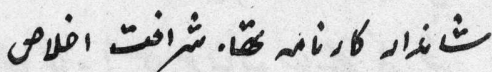

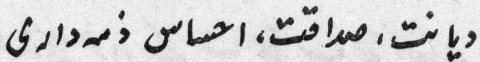

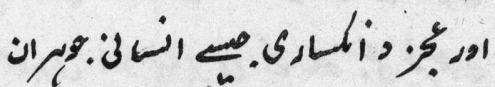
ن

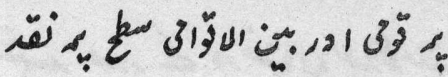

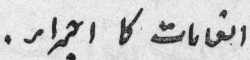

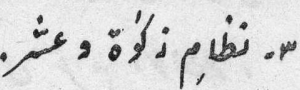
.

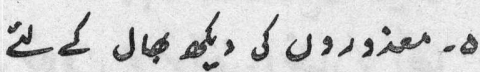

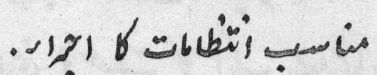

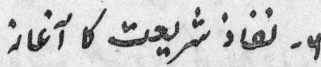

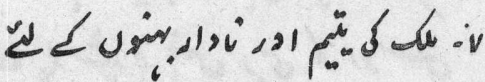

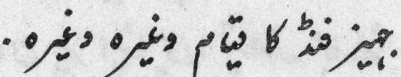

10

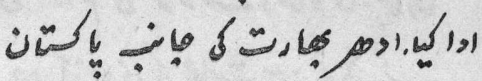

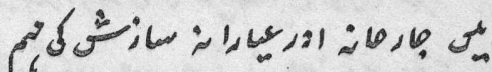
i تلإن

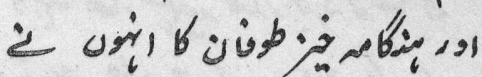

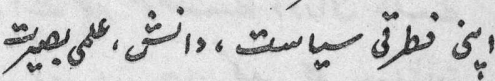

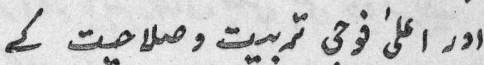
; 6

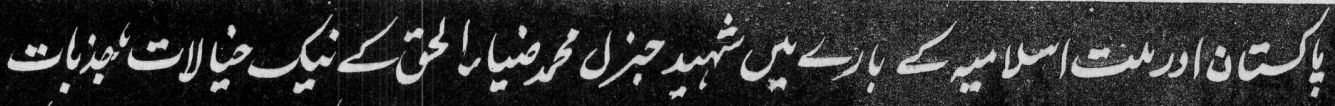

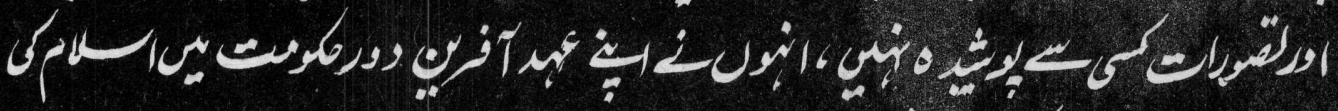

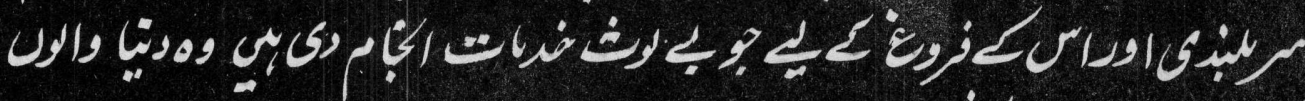
作

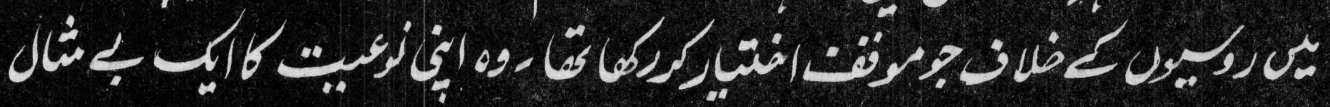
$-20$

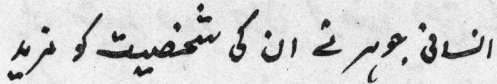

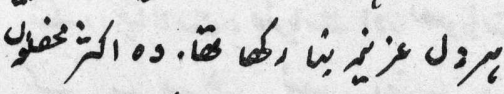

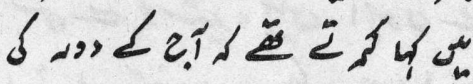

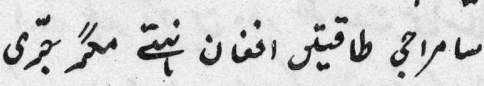

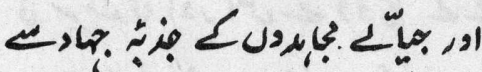
.

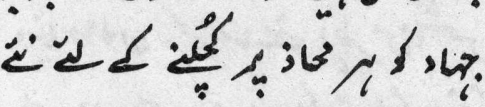

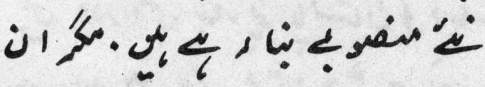

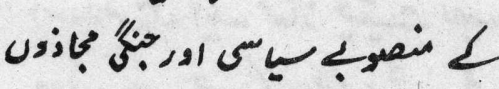

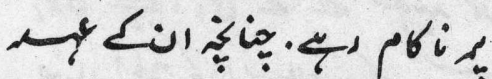

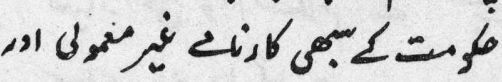

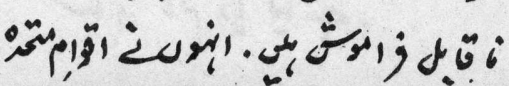

2 范 كَّ.

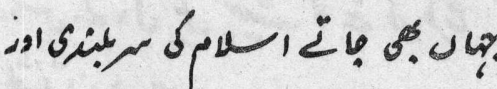

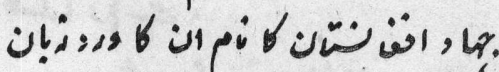

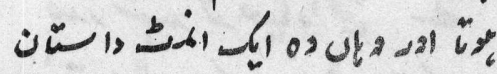

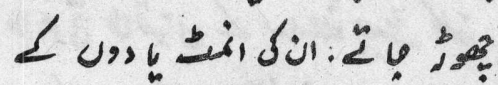

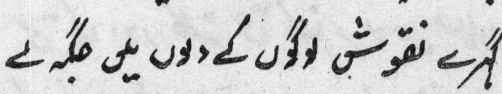

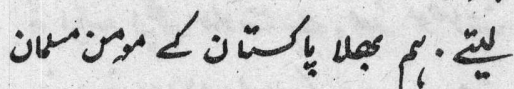

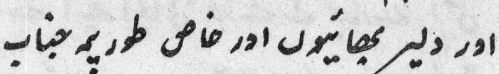
ن U

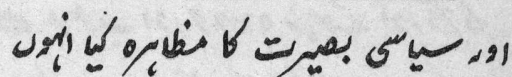
ن

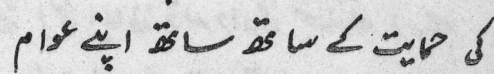

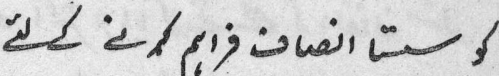
221

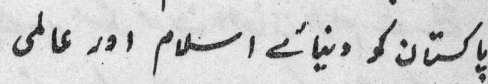

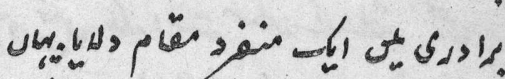

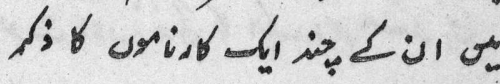

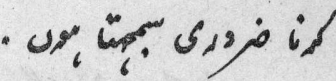

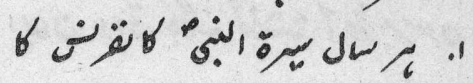

- م"إ" نأ. 


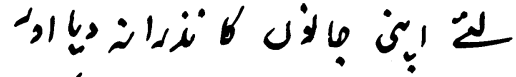

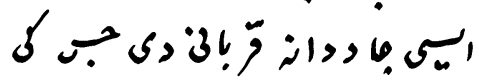

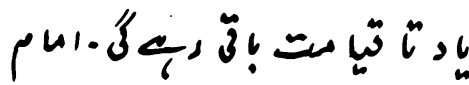


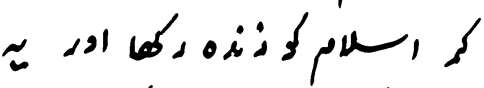

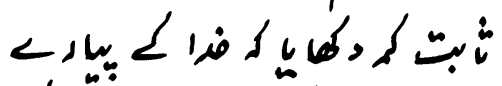

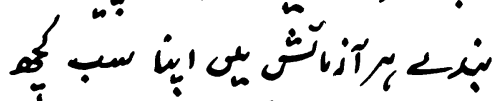

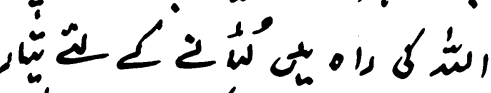

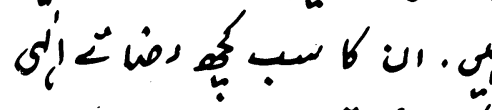

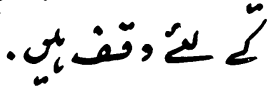

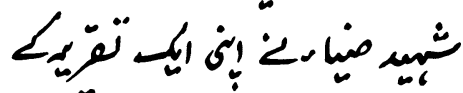

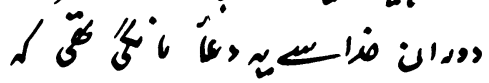

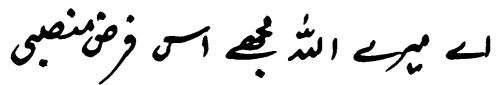

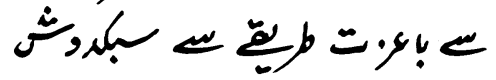

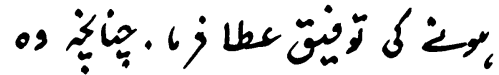

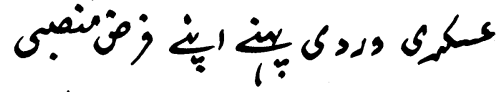

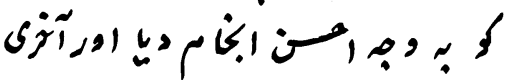

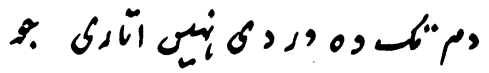

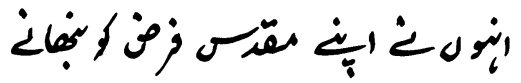
L

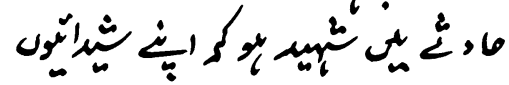

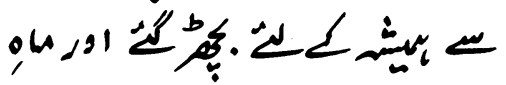

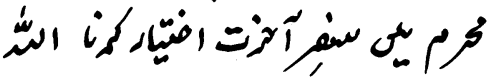

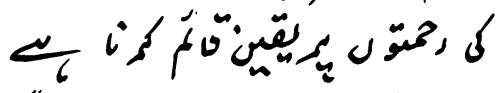

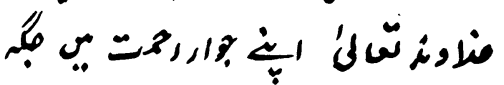
بـ

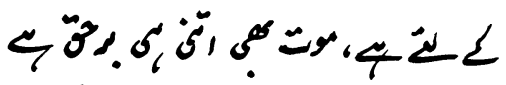

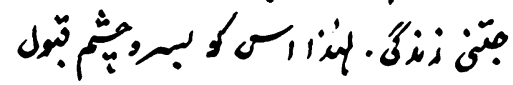

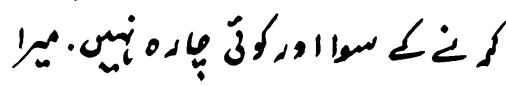

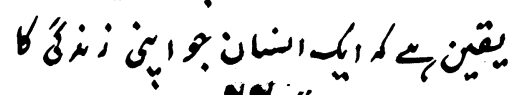
(4)

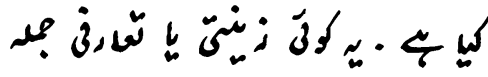

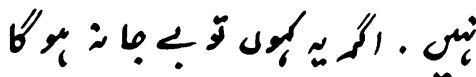

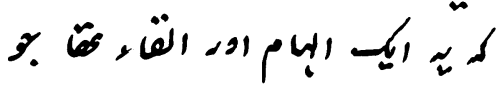

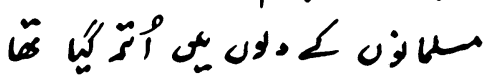

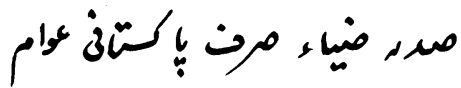

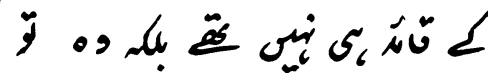

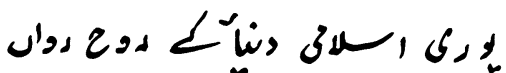

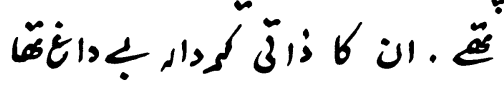

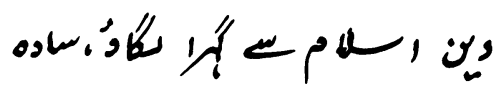

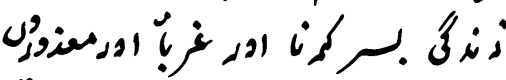

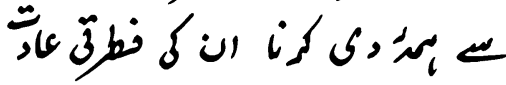

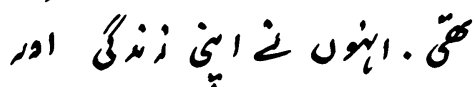

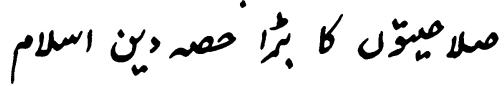
ك

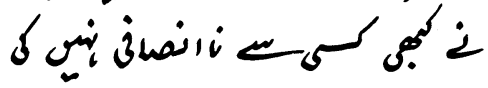

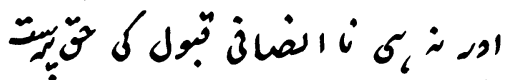
نمغ ار آنز .! , كـ

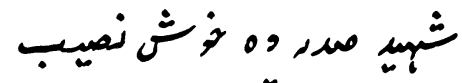

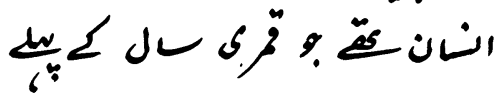

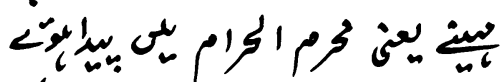

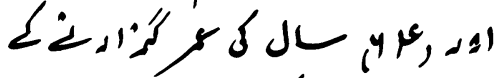

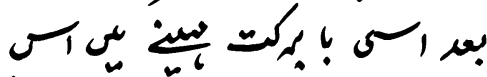

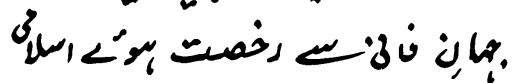

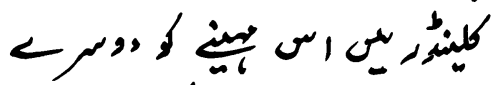

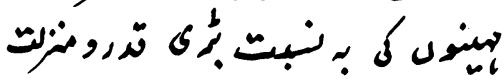

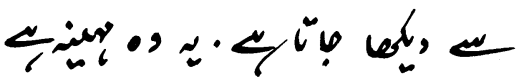

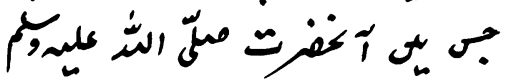

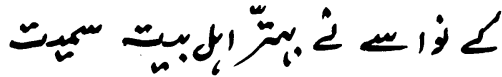

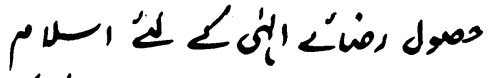

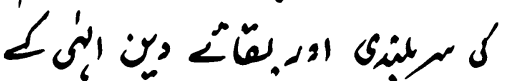

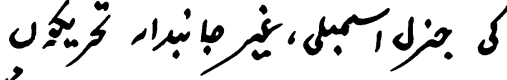

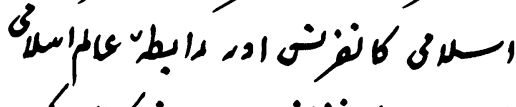

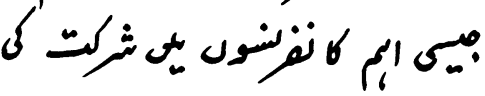

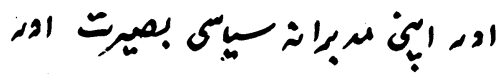

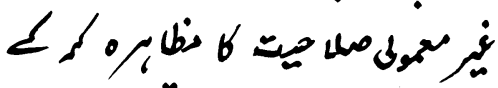

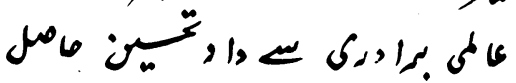

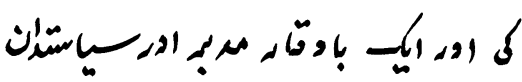

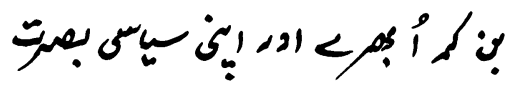
- W

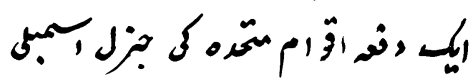

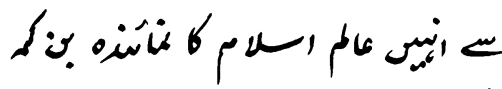

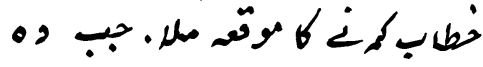
غ ن

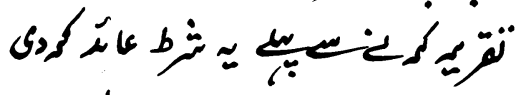

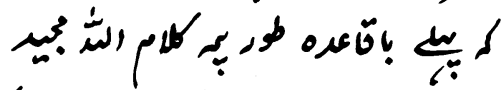

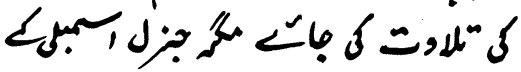

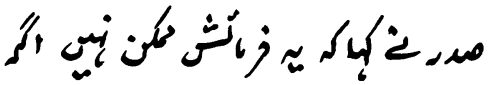

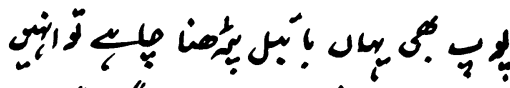

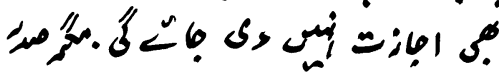

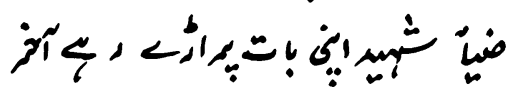

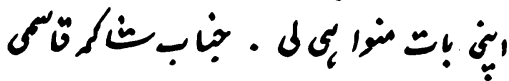

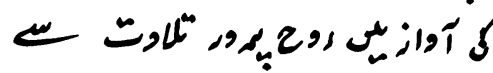

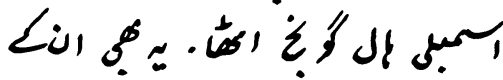

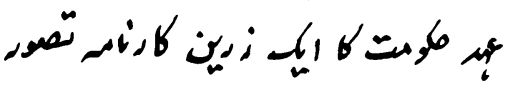
2.1

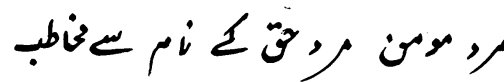

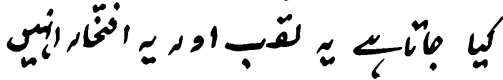

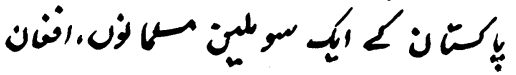

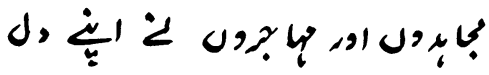

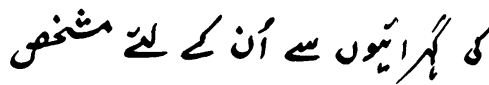




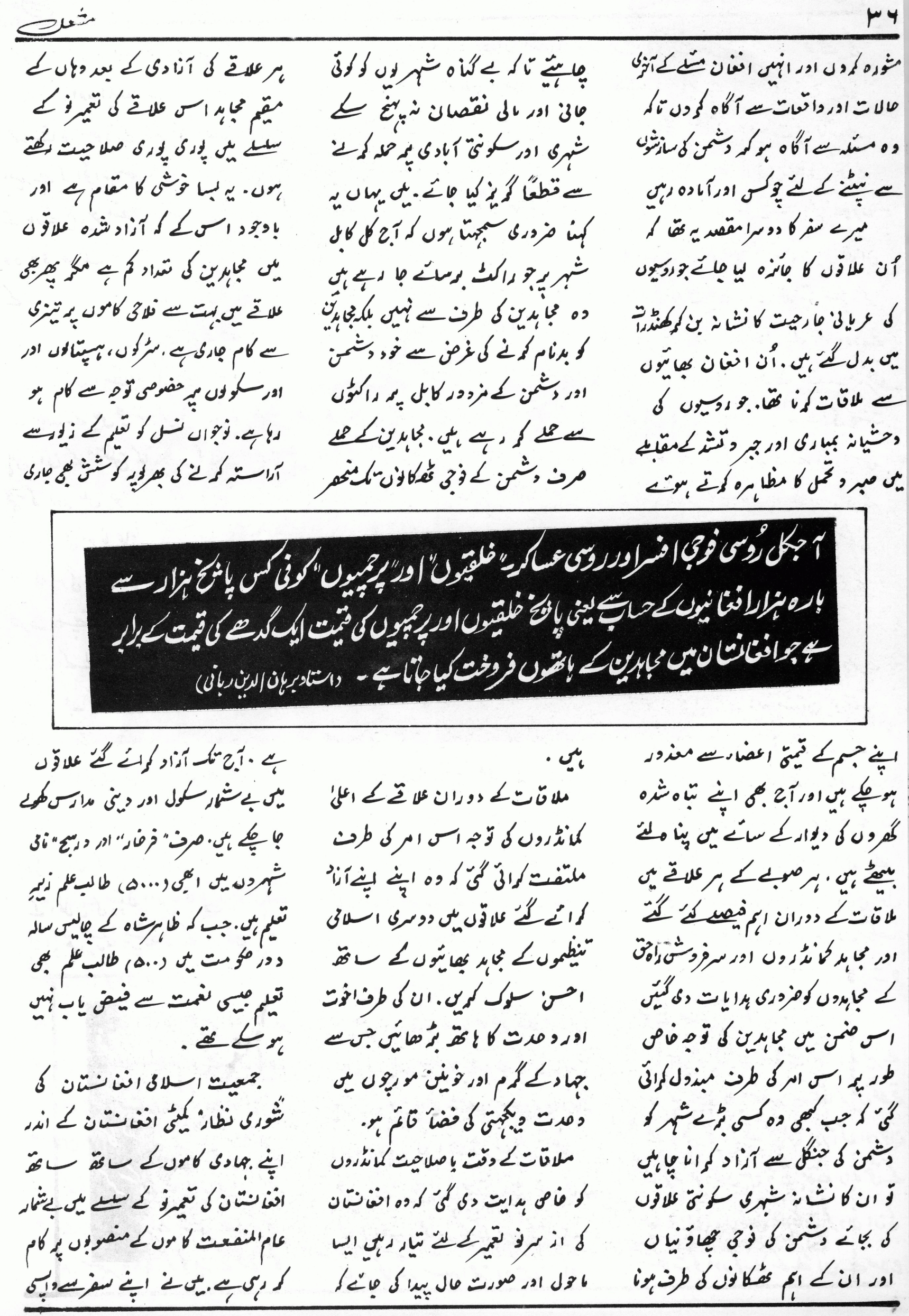




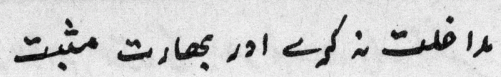

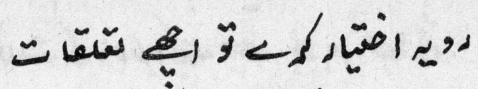

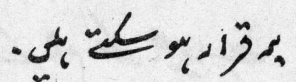

س

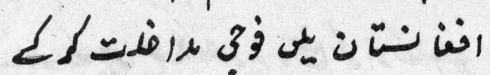

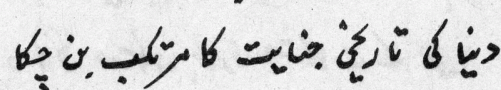

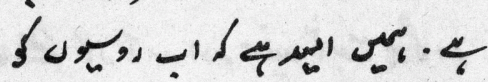
م

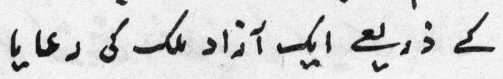

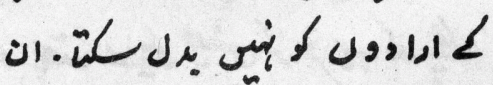
: 0, 15

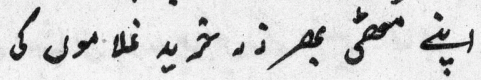
<

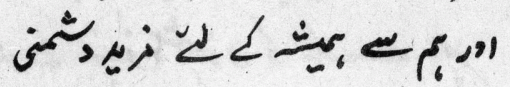
ه ل

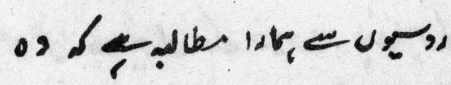

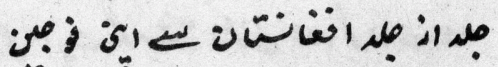

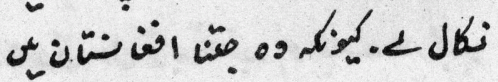
كأه

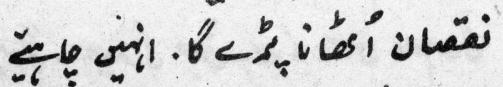

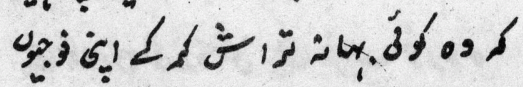

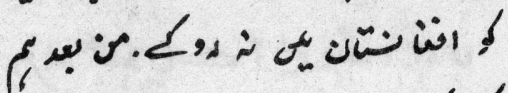
كم 140

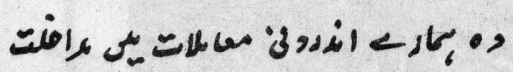

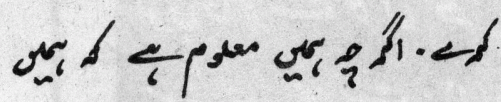

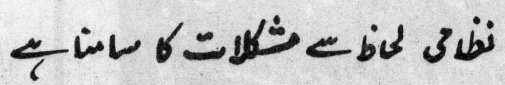
\%

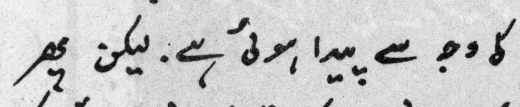

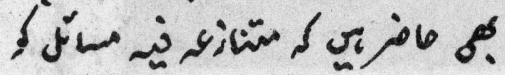

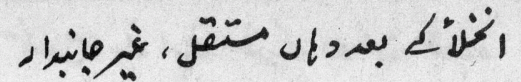

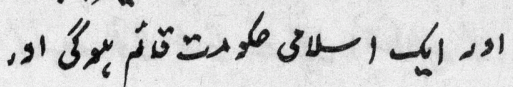

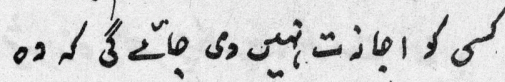

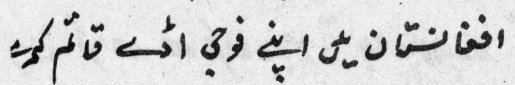
: بن

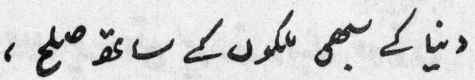

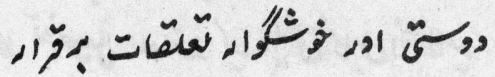
- 14 प्रा

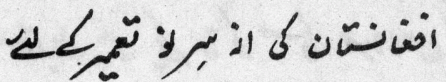

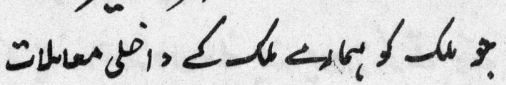

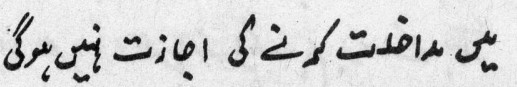

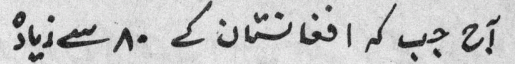

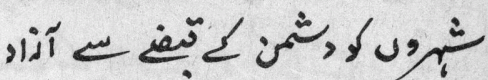

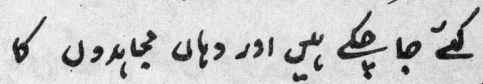
u "ن

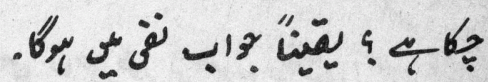

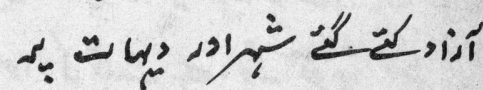

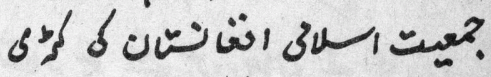
ن

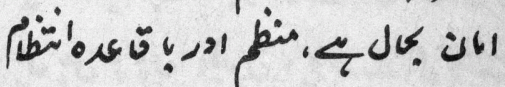

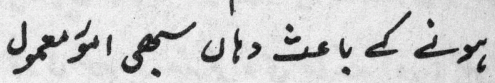
إل

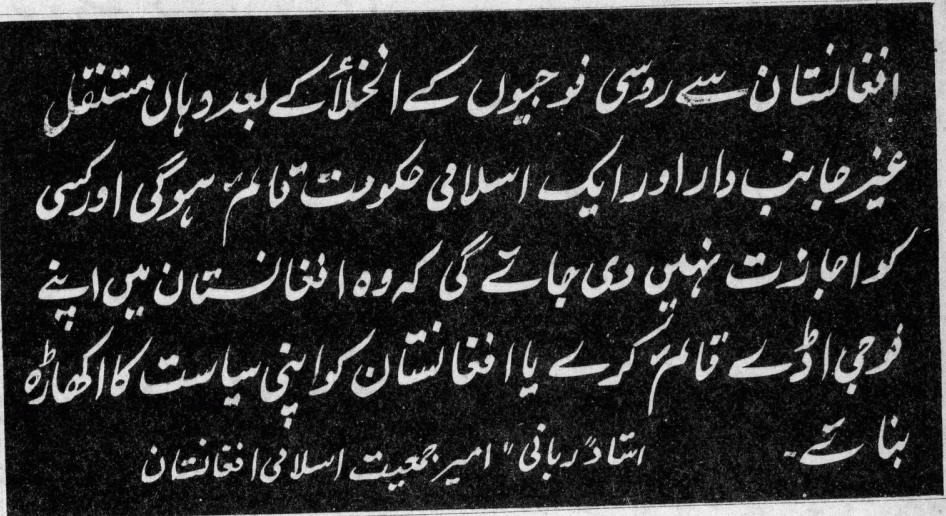

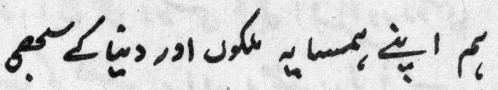
放

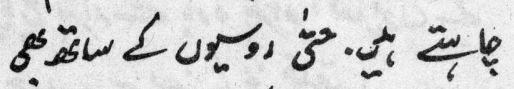
? ร.

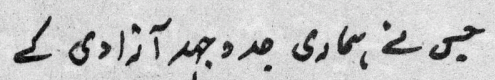

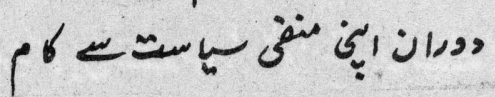
ا

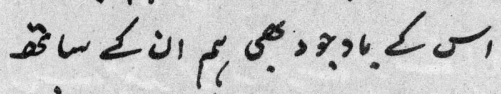

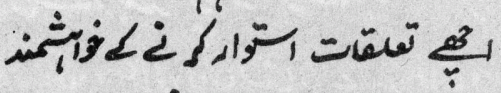

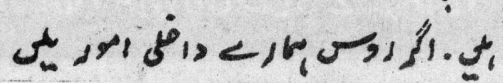

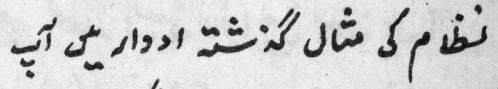
كأل

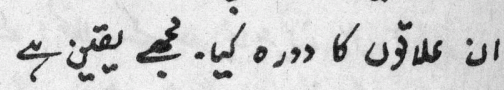

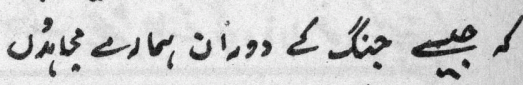
2

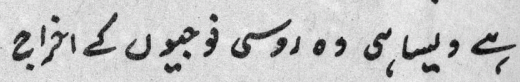

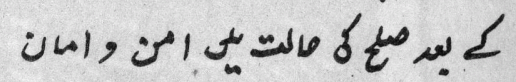

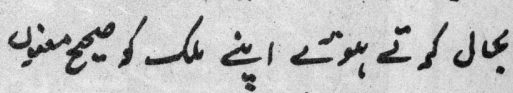

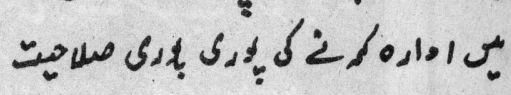

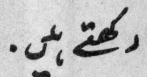

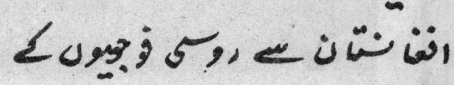




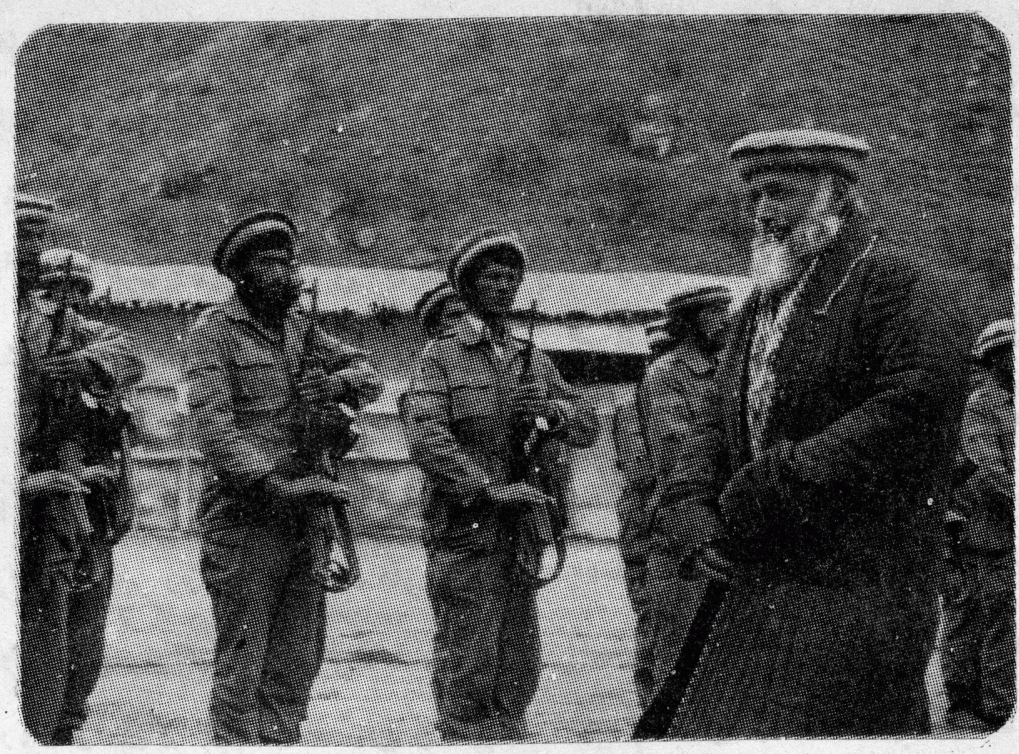

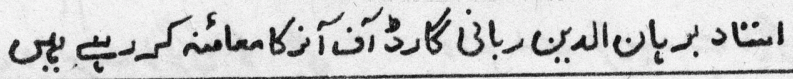

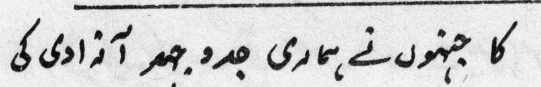

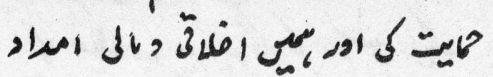

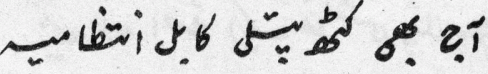
م

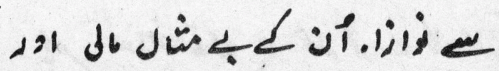
ز

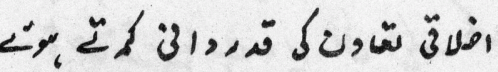

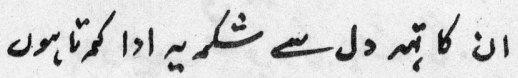

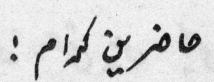

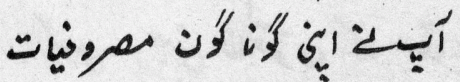

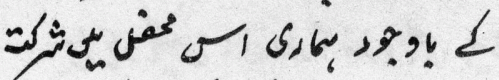

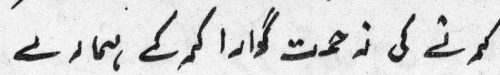

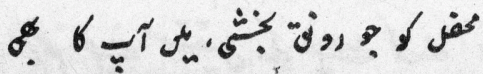

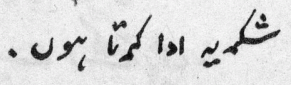

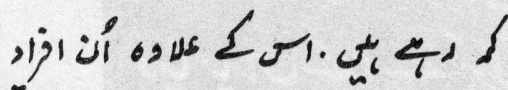

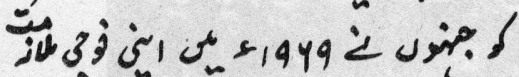

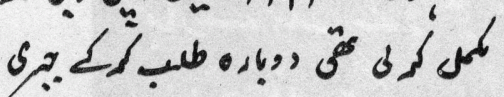

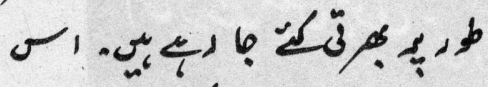

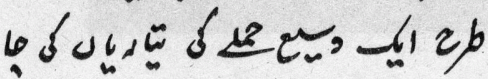

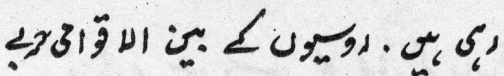

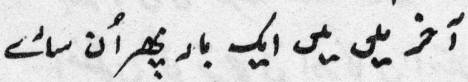

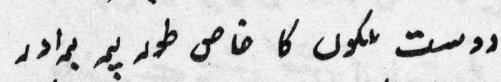

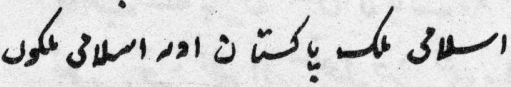

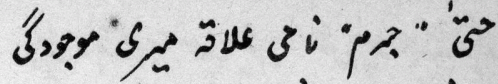

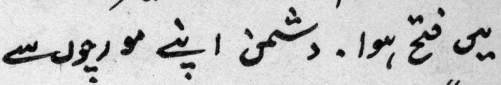
- كبال

ل6.

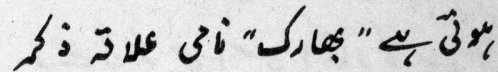

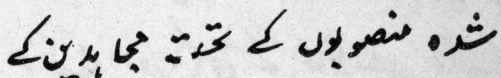

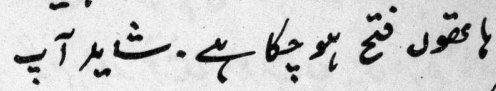

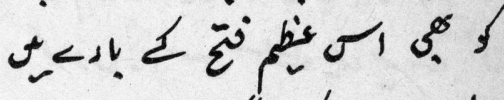

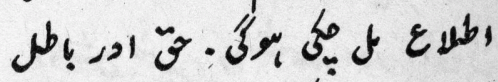

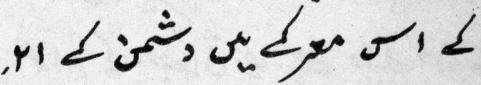

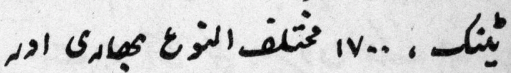

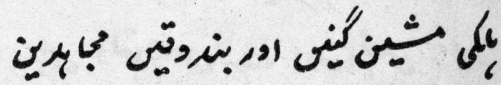

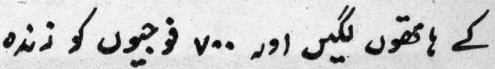

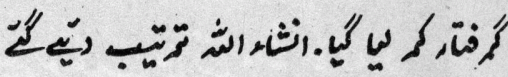

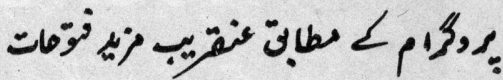

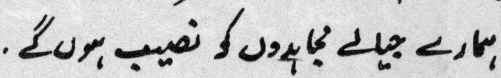

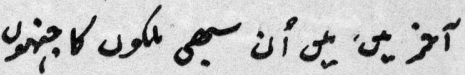

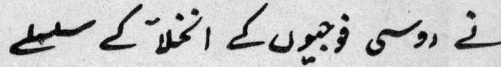

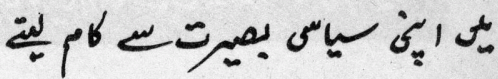

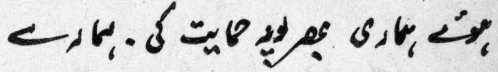

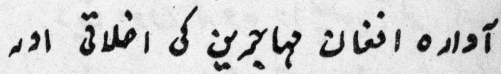
191 ل

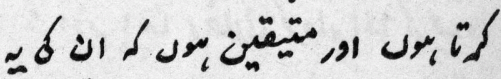

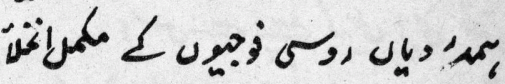

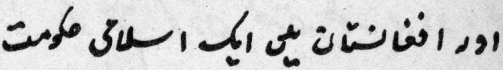

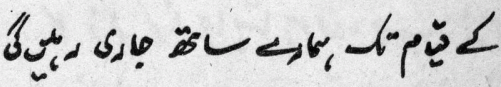

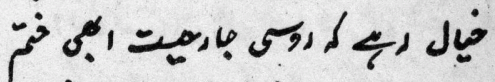

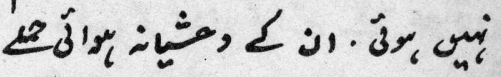

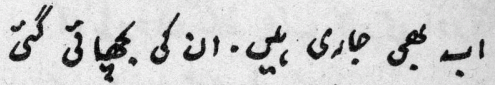

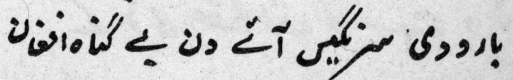

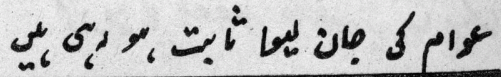


(1)

en

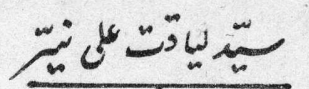

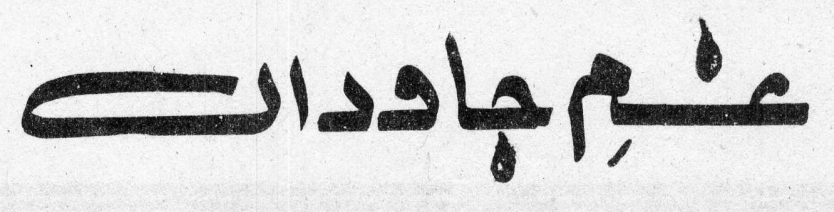

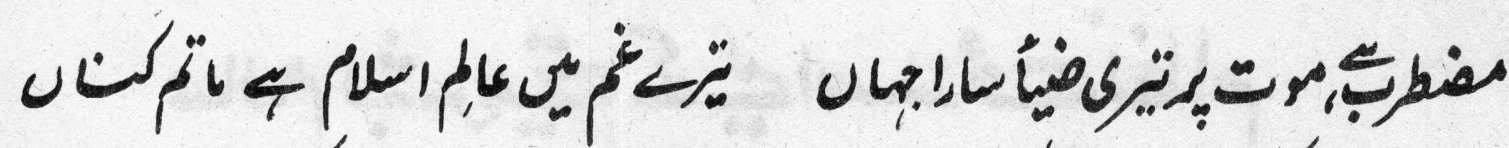

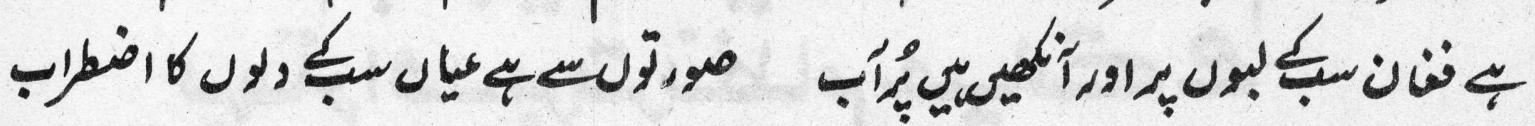

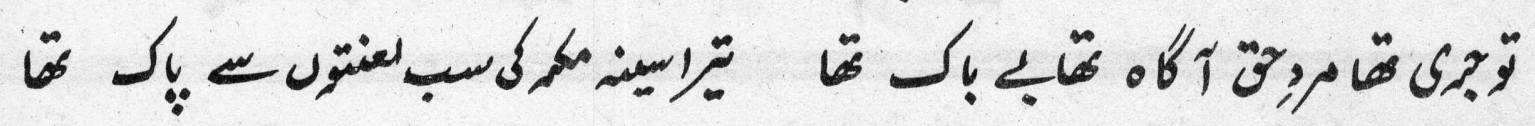

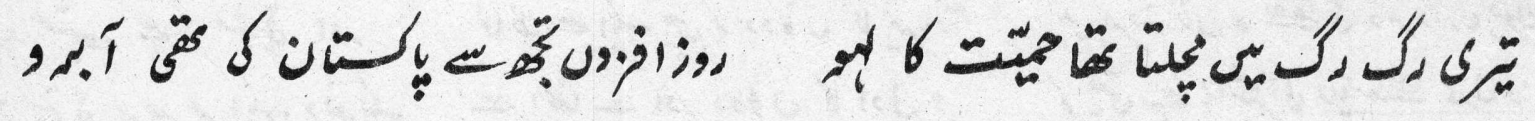

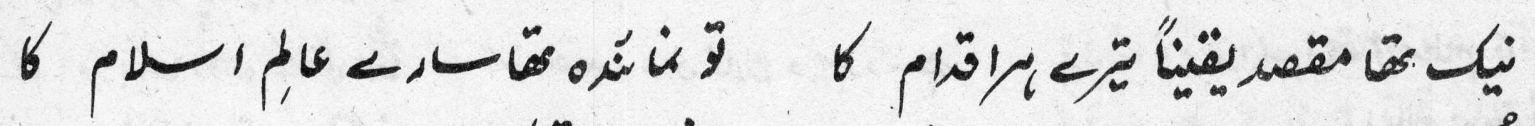

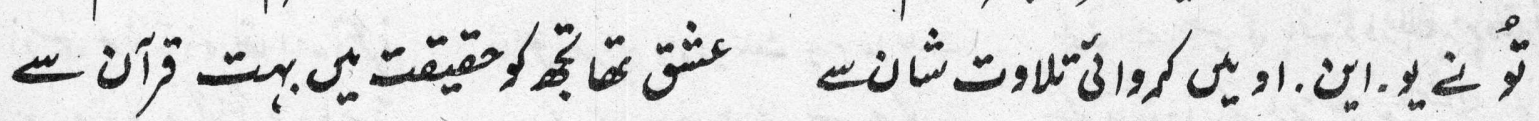

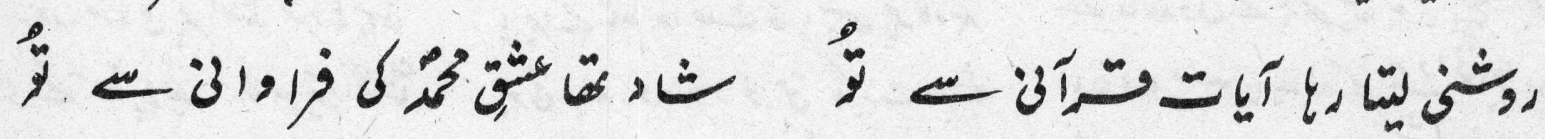

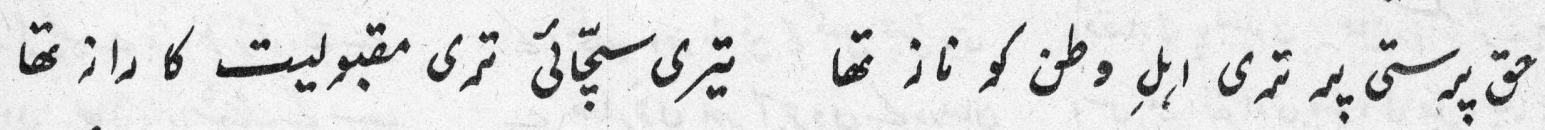

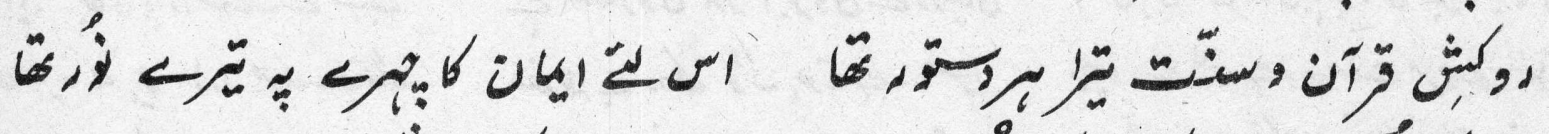

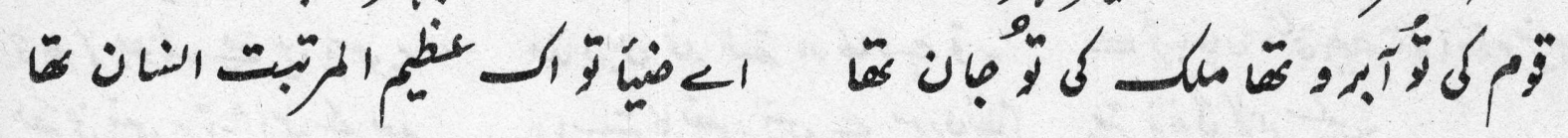

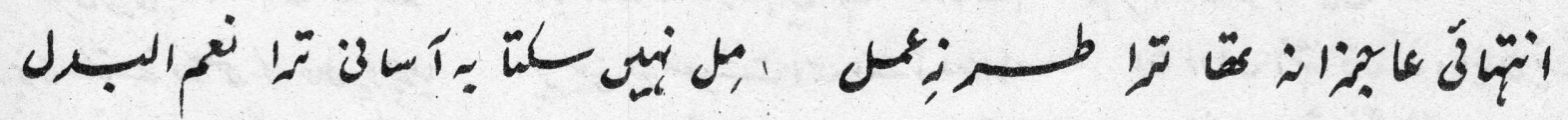

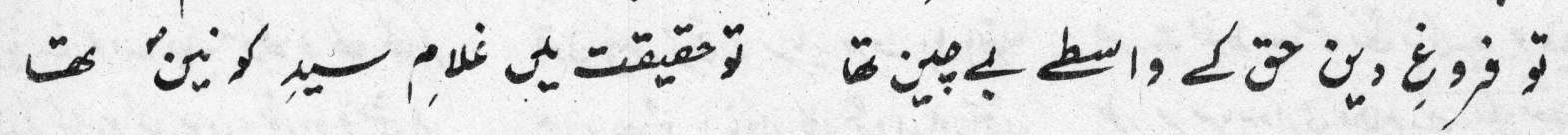

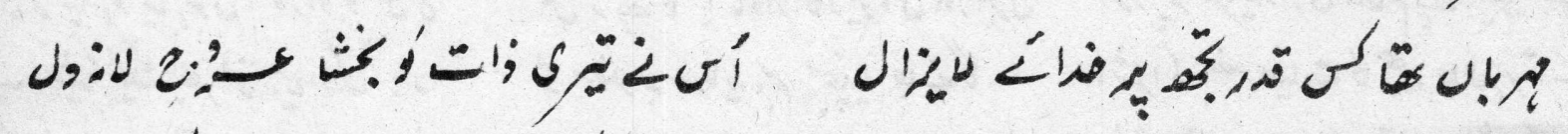

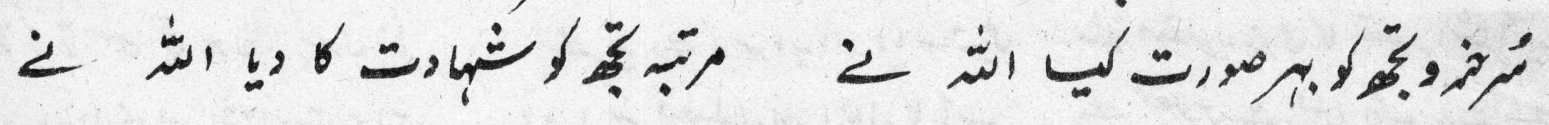

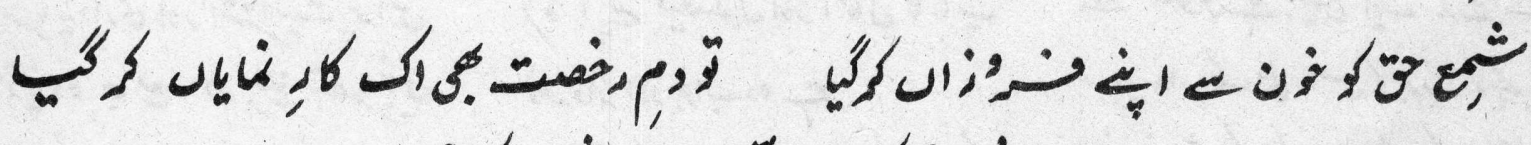

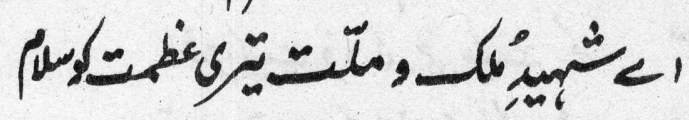

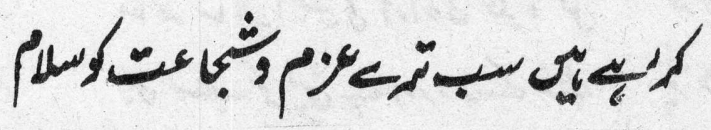




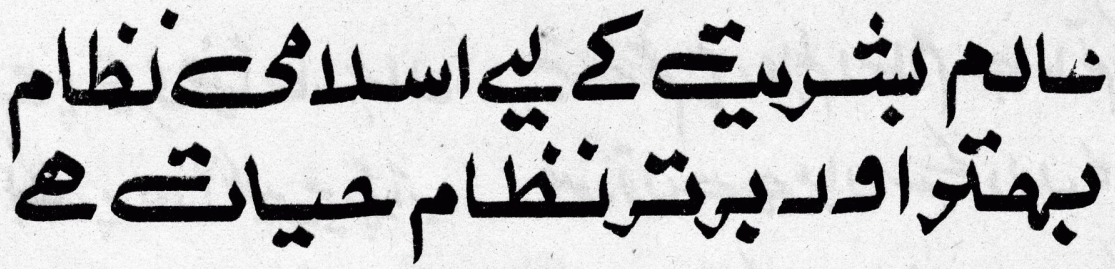

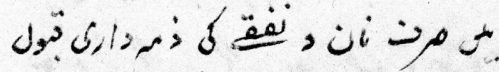

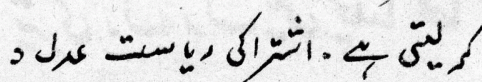
لز

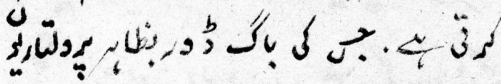

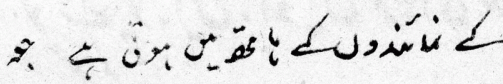

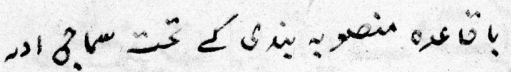

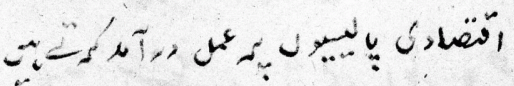

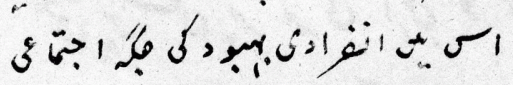

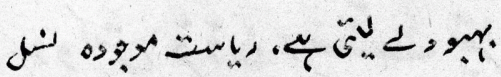
بـ

$$
\text { . بئش }
$$

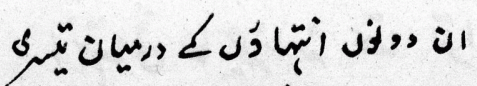
صورت

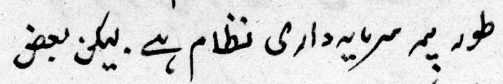

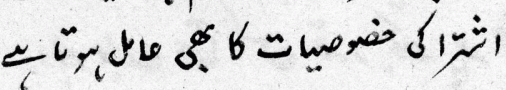

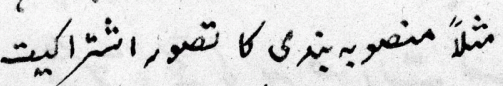
ب

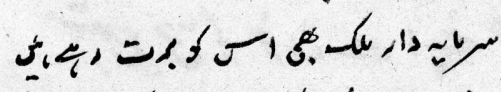

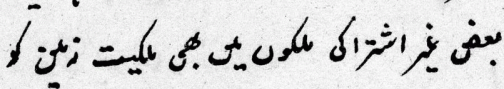

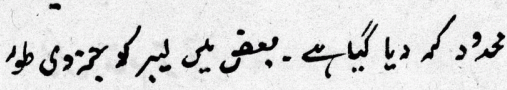
ك

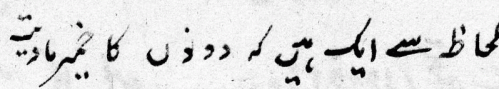

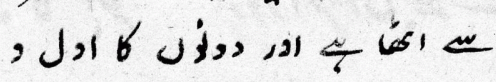

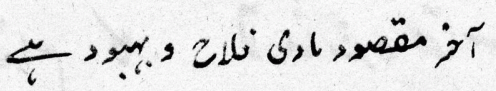

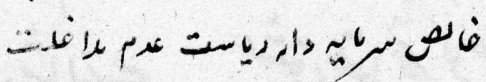

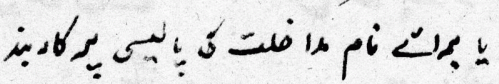
ث

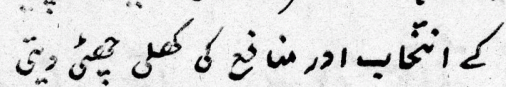
政

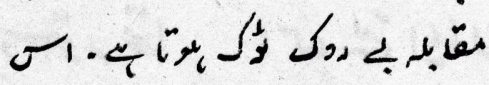

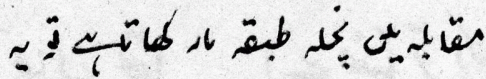

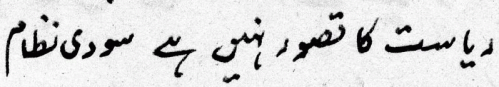

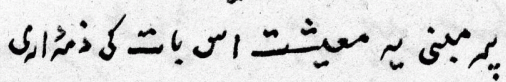

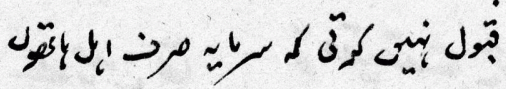
政

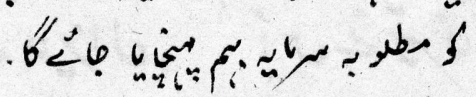

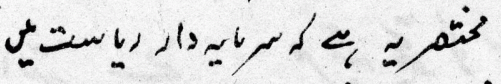

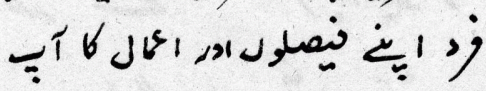

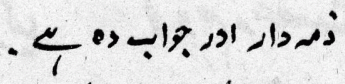

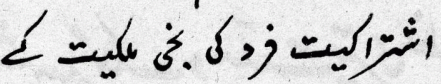
年 صه
البيف تهمه

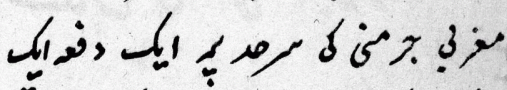

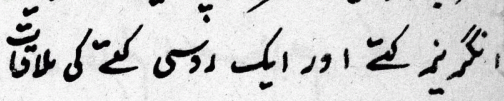

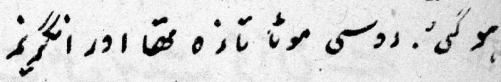

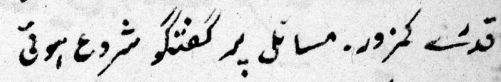

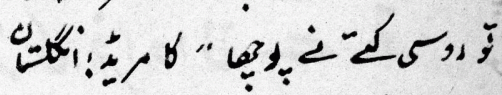
L

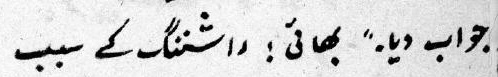

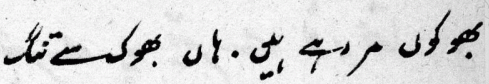

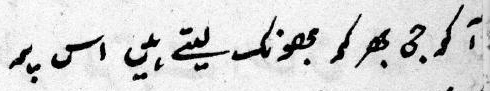

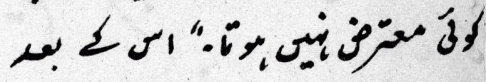

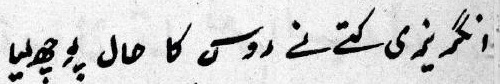

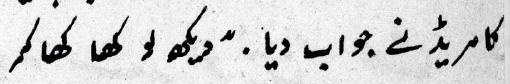

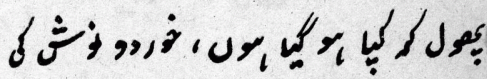

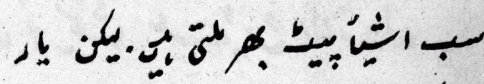

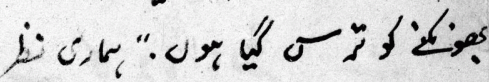

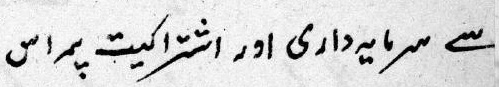

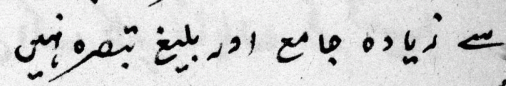
$.1, j$

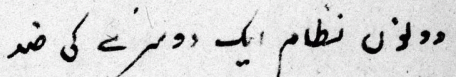
Lج 


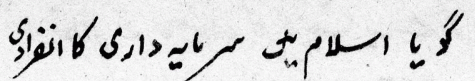

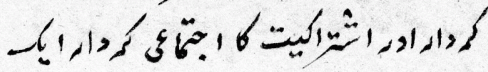

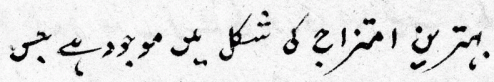

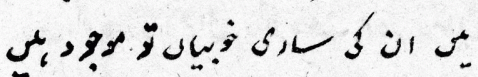

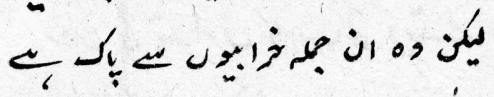

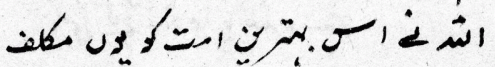
占

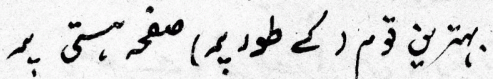

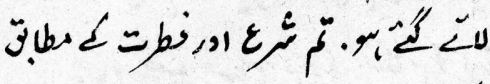

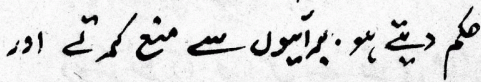

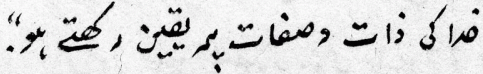

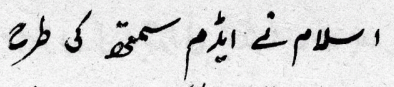

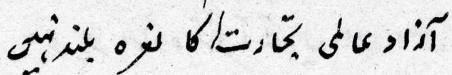

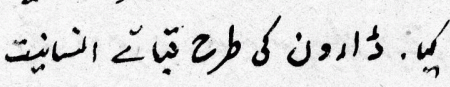
2) 万人

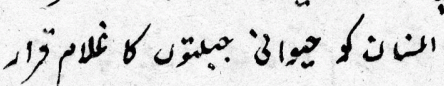

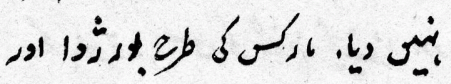

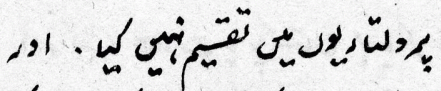

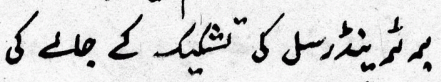

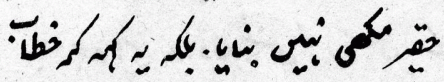

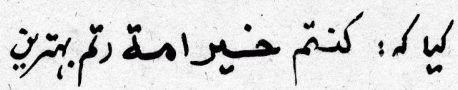
(2) ; م دار.8

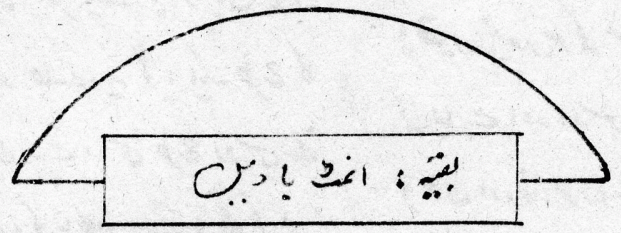

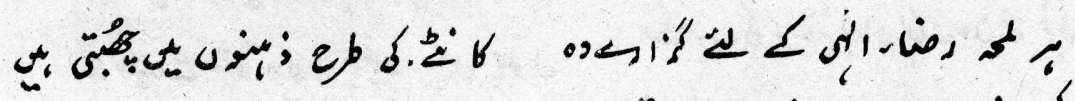

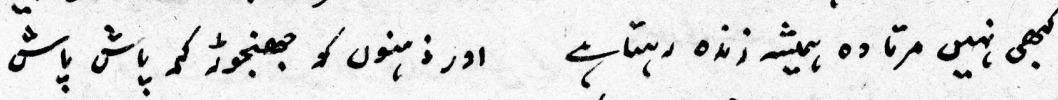

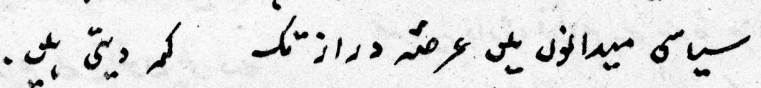

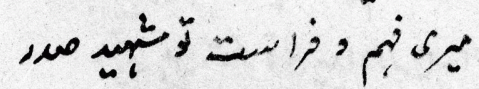

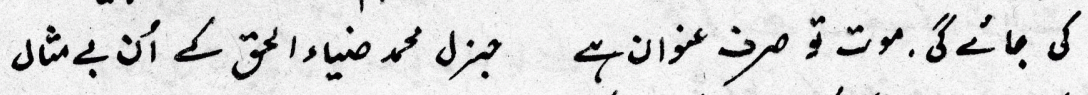

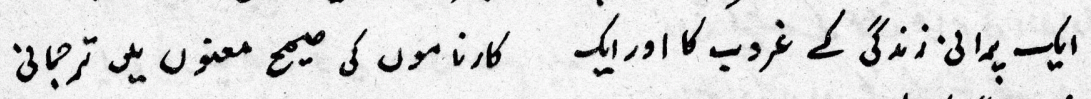

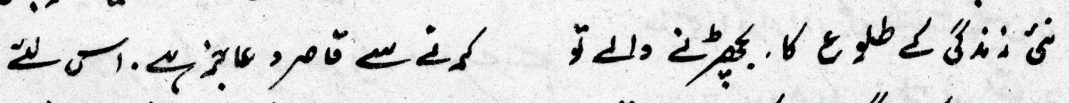

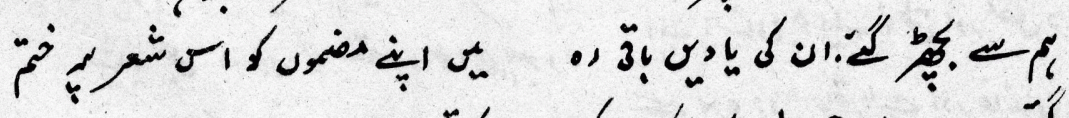

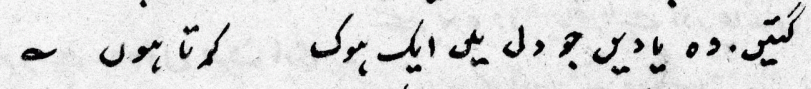

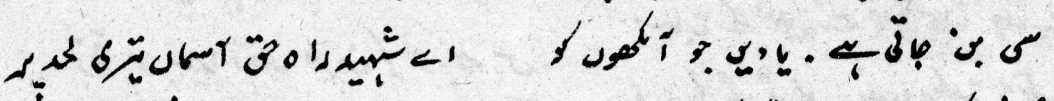

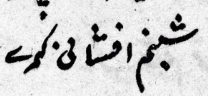

تئرك

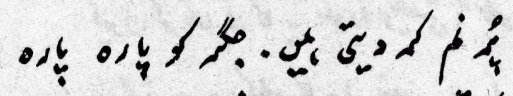
(1)

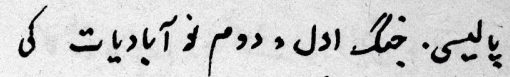

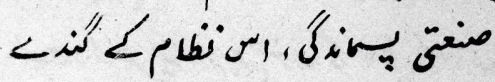

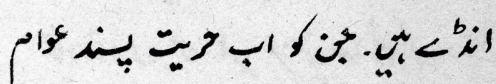

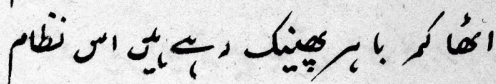

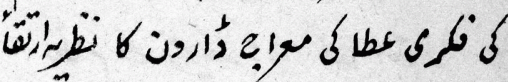
اور ز

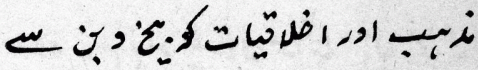

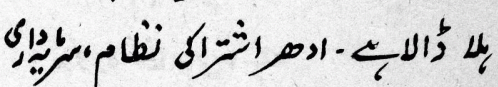

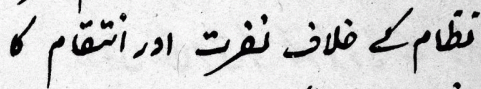

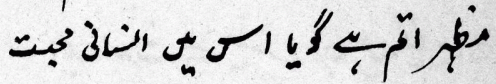

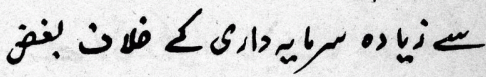

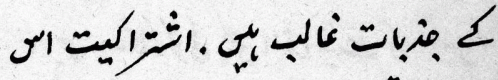

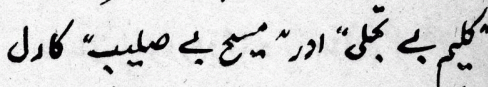

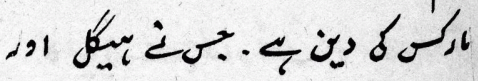

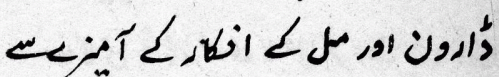

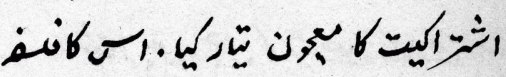

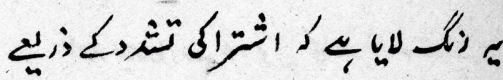

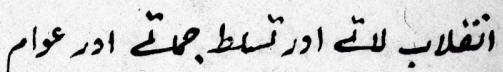

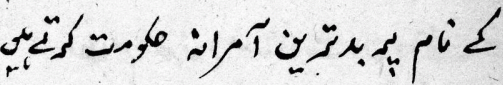

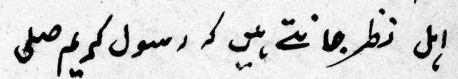

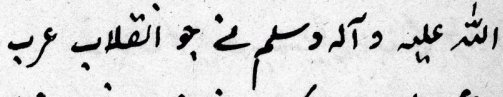

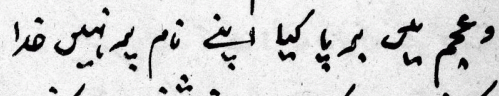

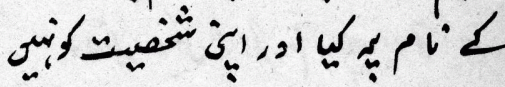

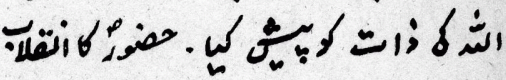

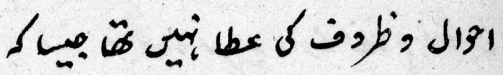
مالهي

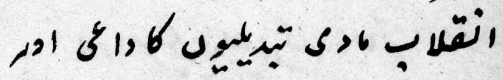

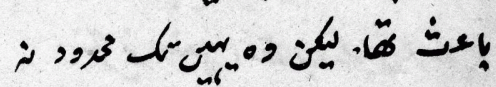

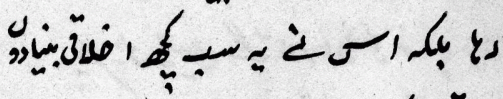

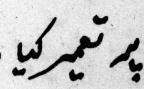




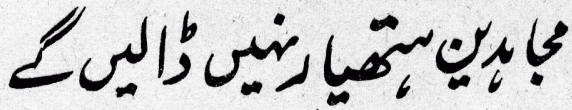

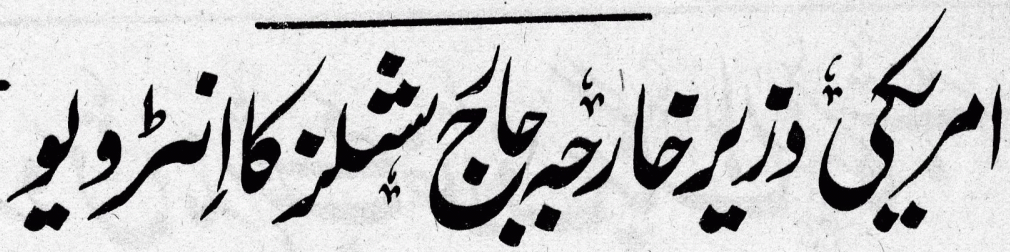

si

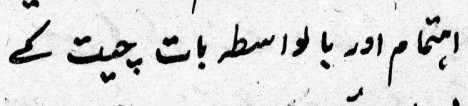

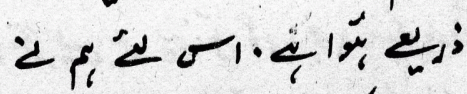
ك 䒠 जा

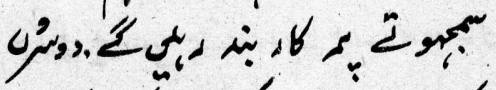
. L

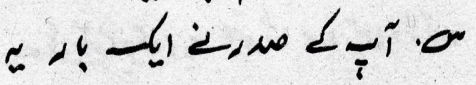
少. إن, < هل

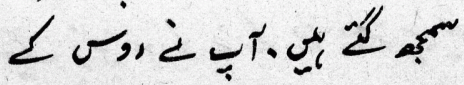
$\gamma_{5}=\underbrace{}_{0}$

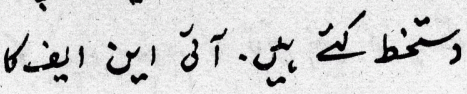

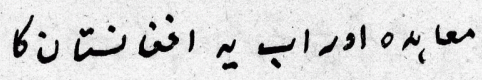
† है

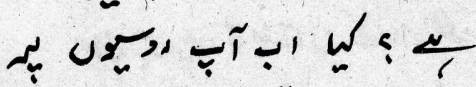

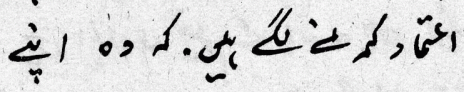

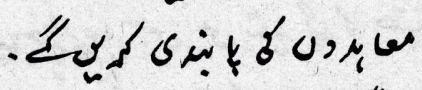
$\angle$ जय
ك

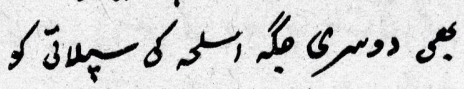

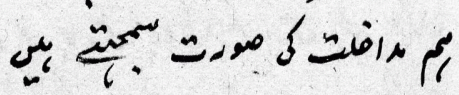
". ؟

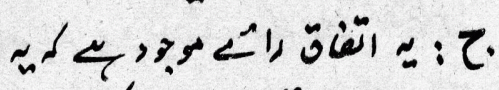
, اور

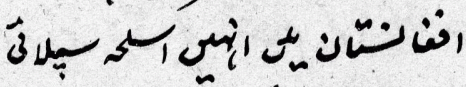
or 30.3.

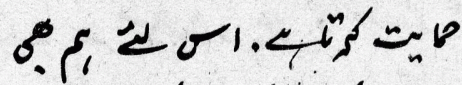
لـ

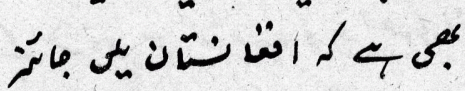
مك

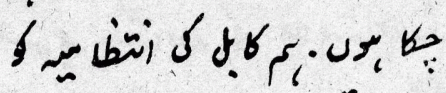

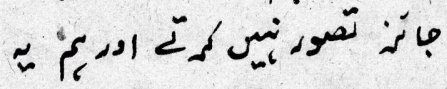
+

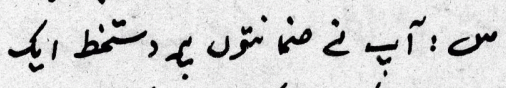
أس حك

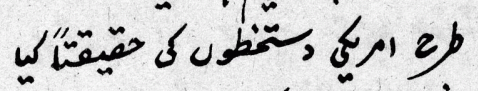
W .

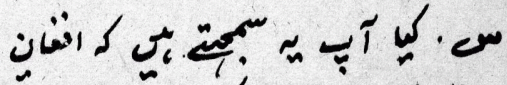
تصنيف

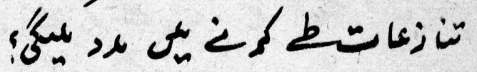
ك, ح.

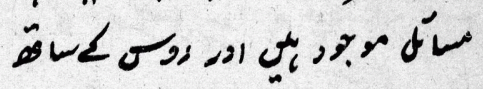

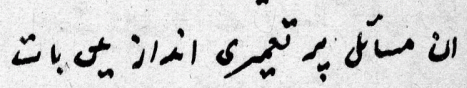
مي أنا

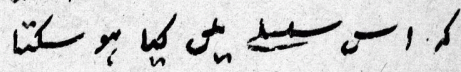

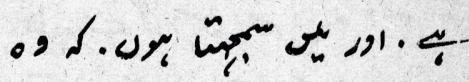

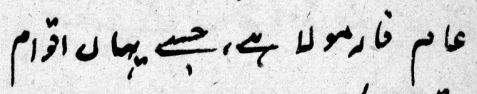
مصى "ע

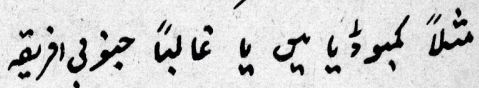
S. . 4 in ó ? $4,1 / \mathrm{w}$

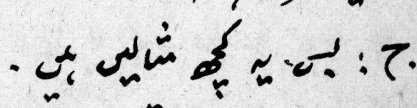

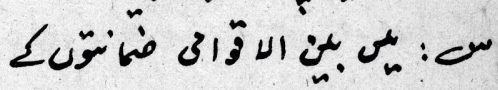

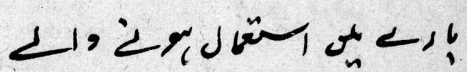

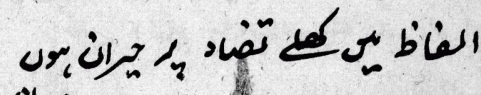

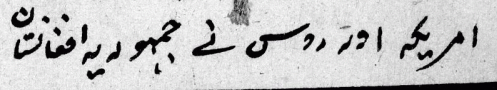


تر

ma

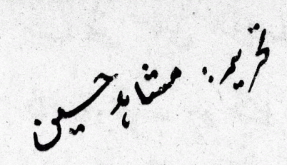

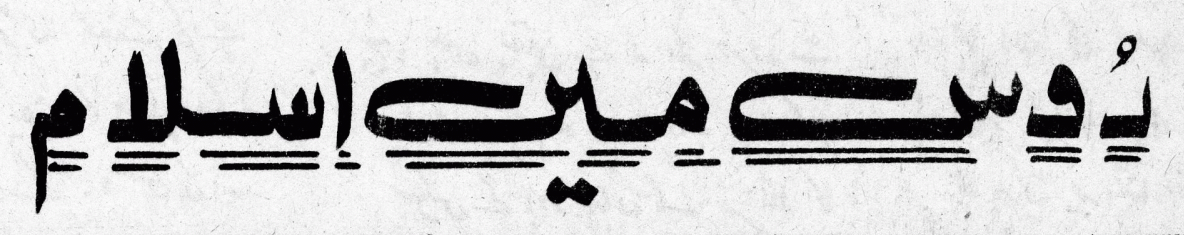

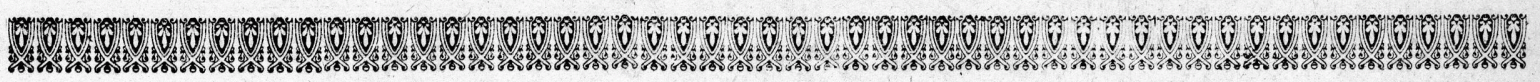

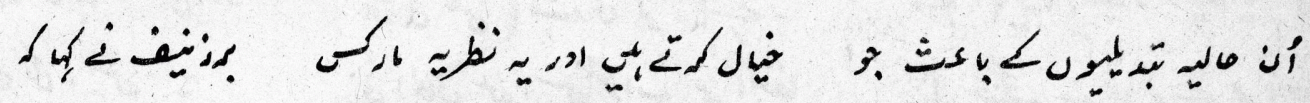

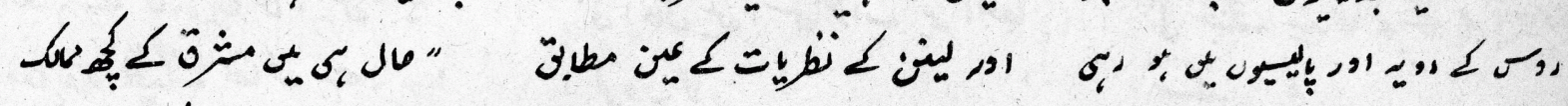

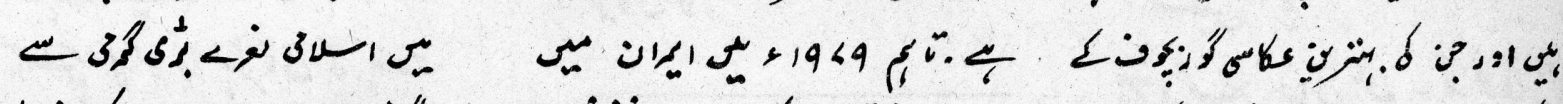

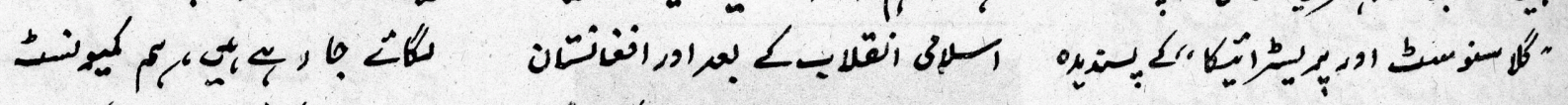

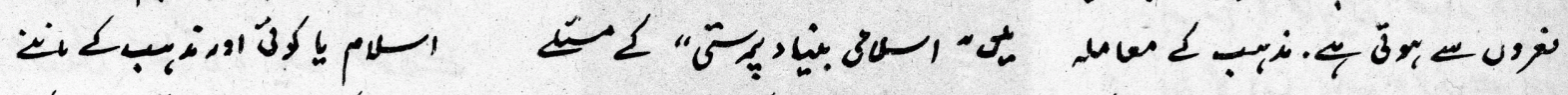

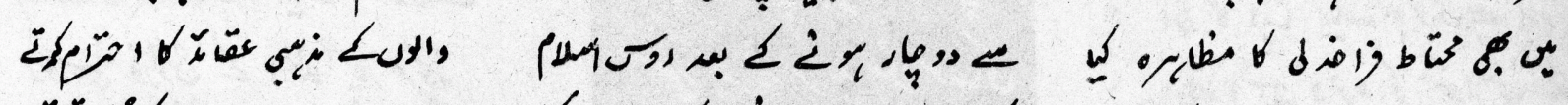

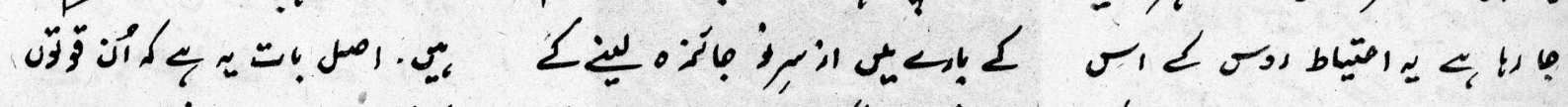

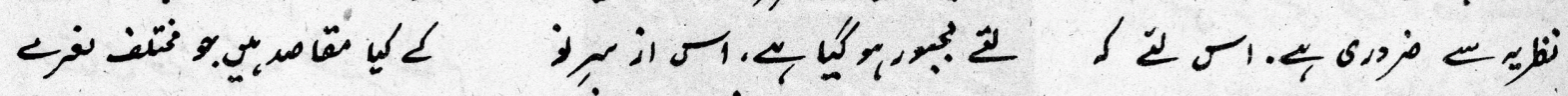

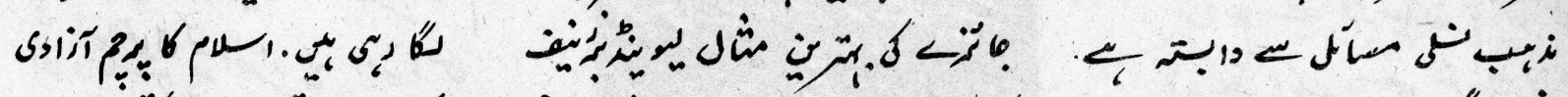

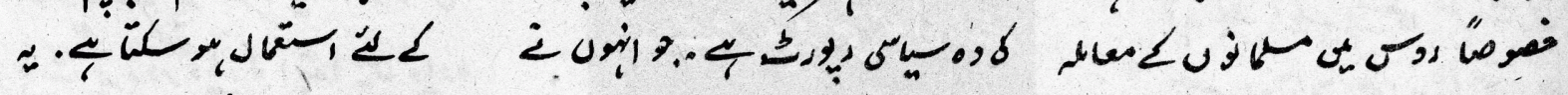

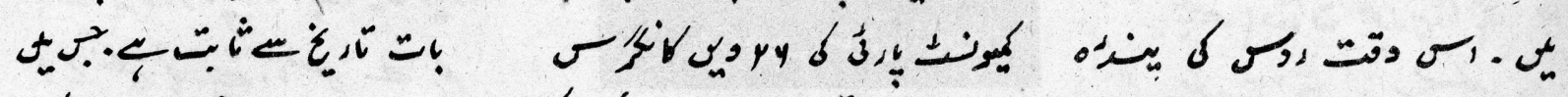
.

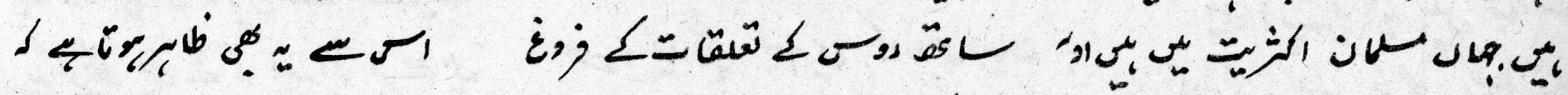

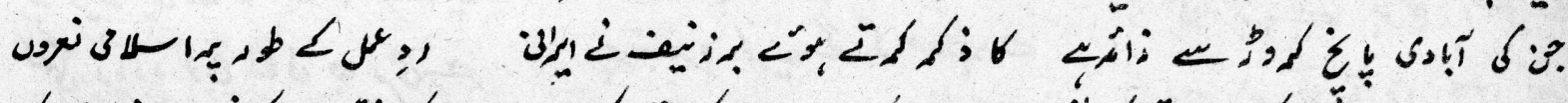

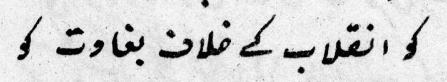

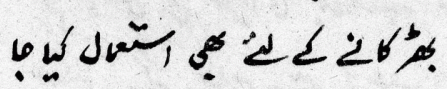

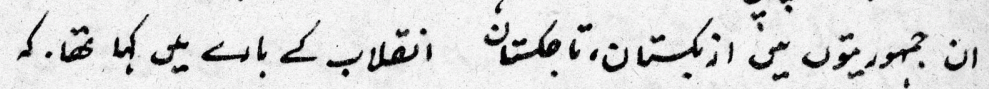

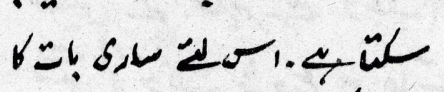

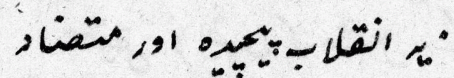

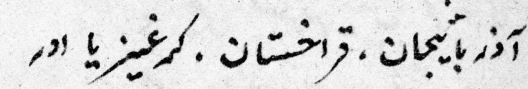

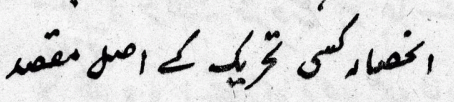

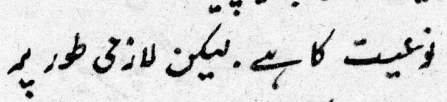

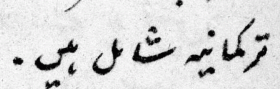
"ن

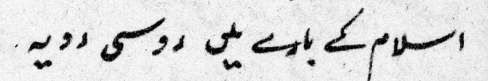

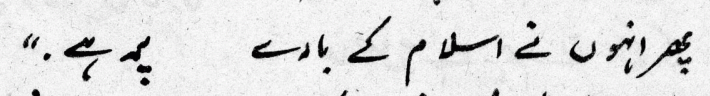
وأس

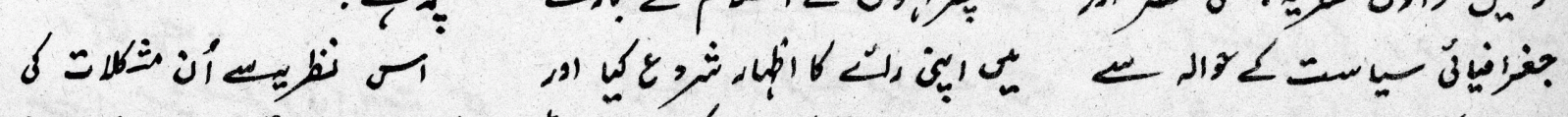

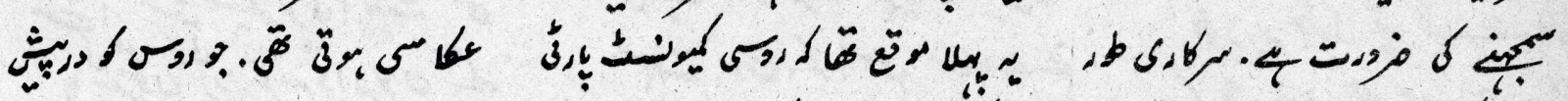

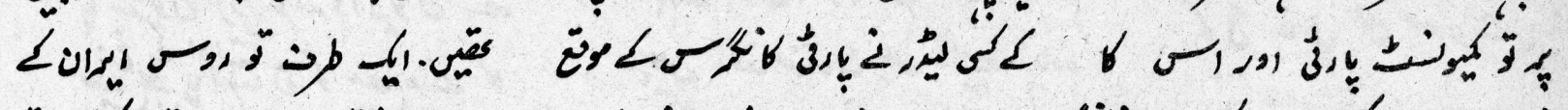

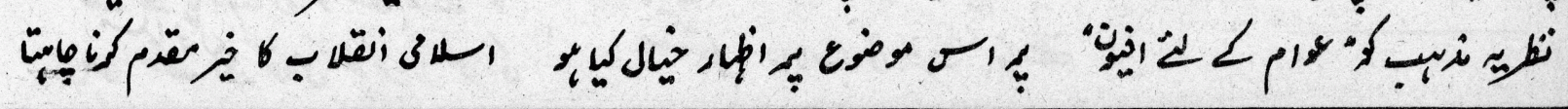




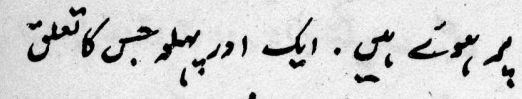
ندب-

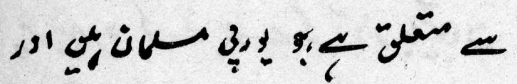

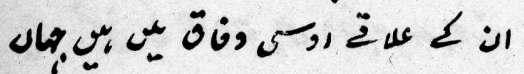

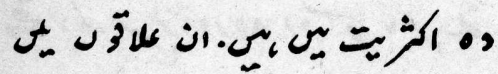

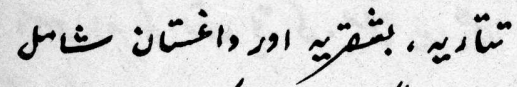
6.

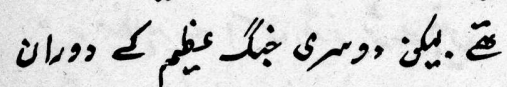
الن يمان

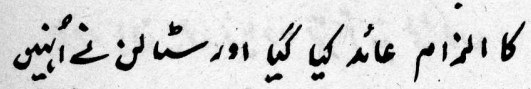

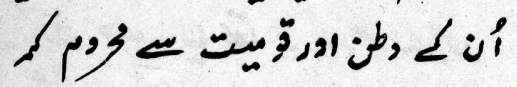

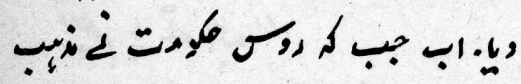
Wo لـ

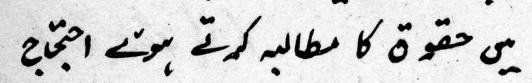

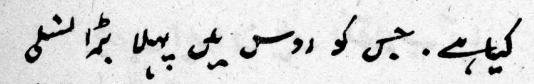
احجّاجس

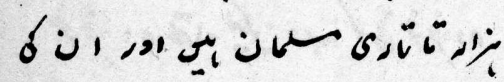

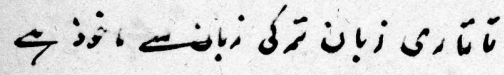

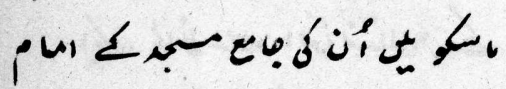
إli ز "

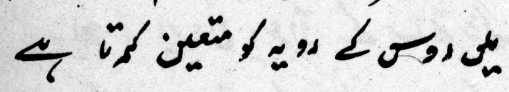

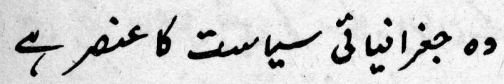

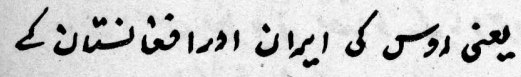

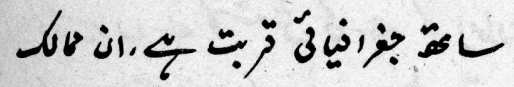
L 2 " ر"ن

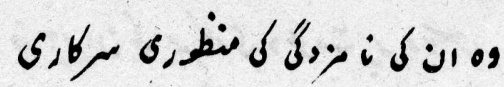

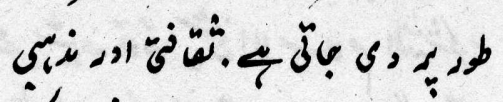
¿ \%

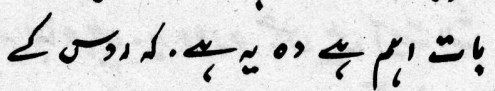

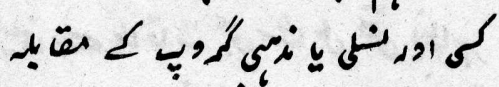

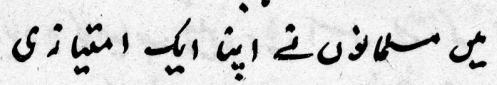

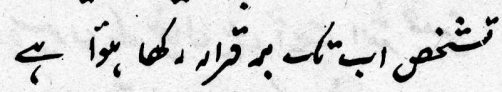

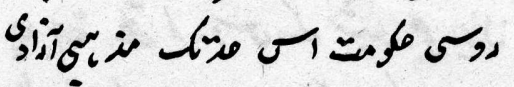

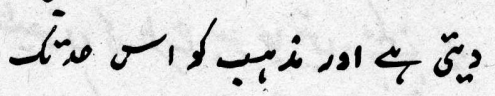

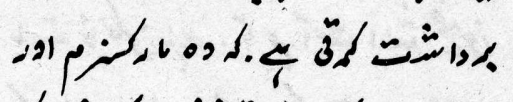

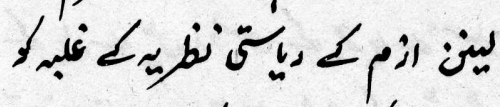

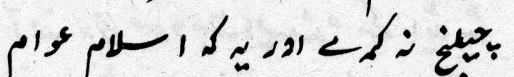

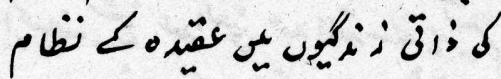
. 4 ك موله

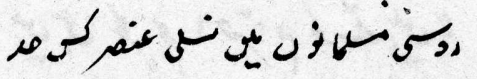

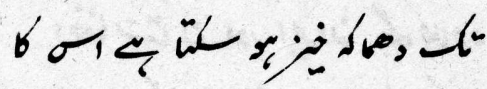
ز

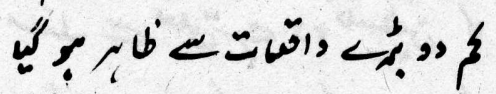
ك. ए 2

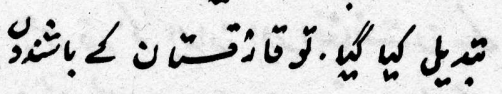
21

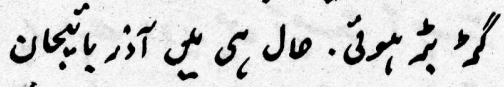

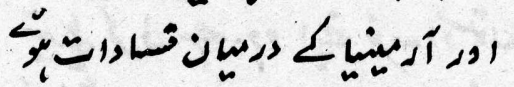

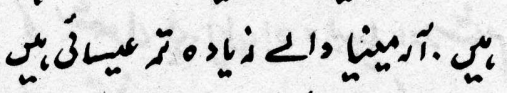

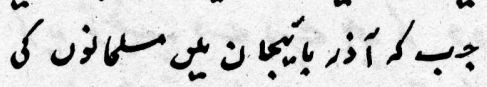

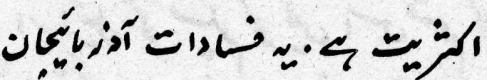
سأر ل

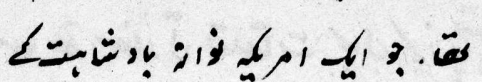

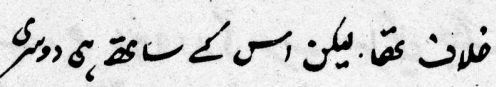

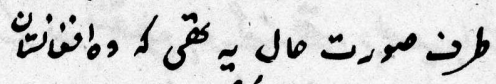

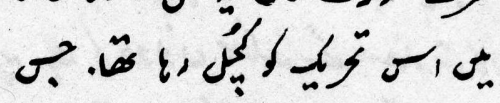

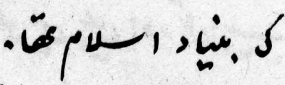

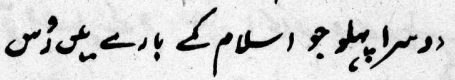
تص

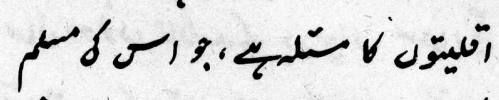

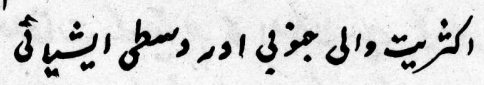

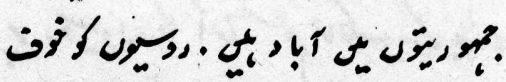

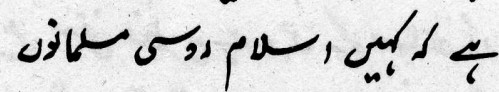
(2)

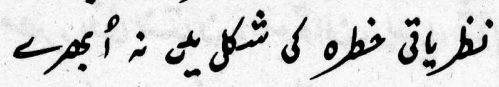

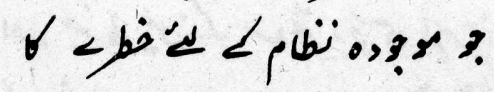

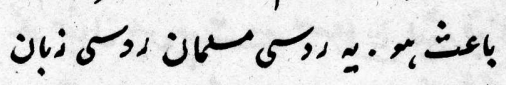

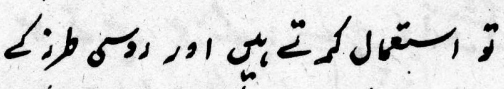

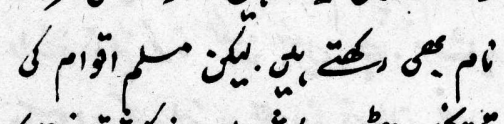

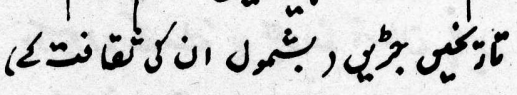

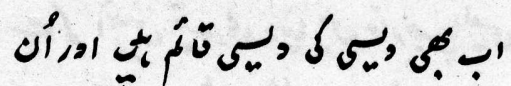

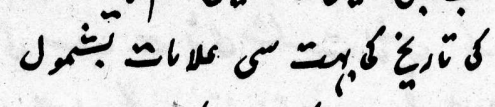

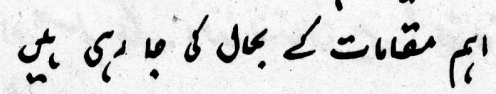

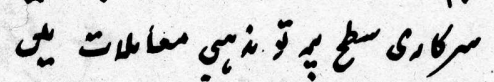

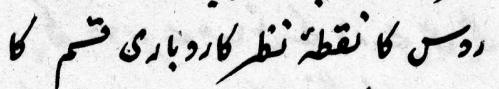

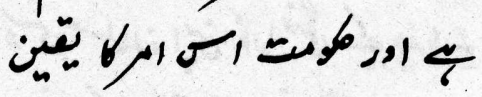

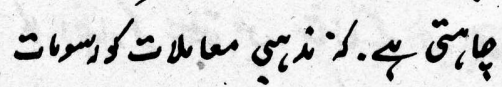

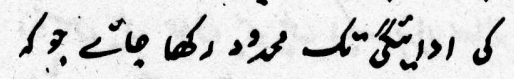

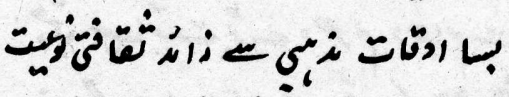

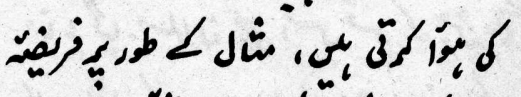

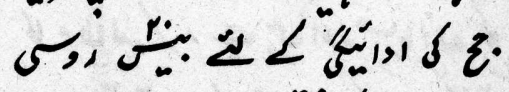
وأ 
ث

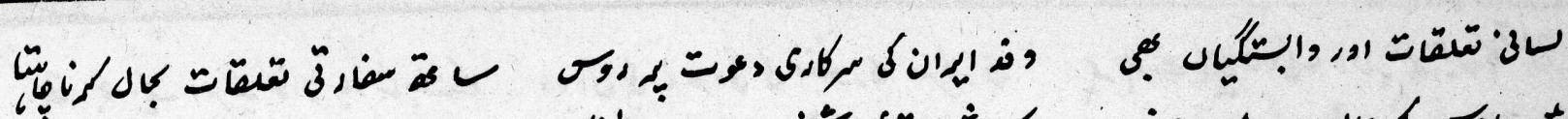

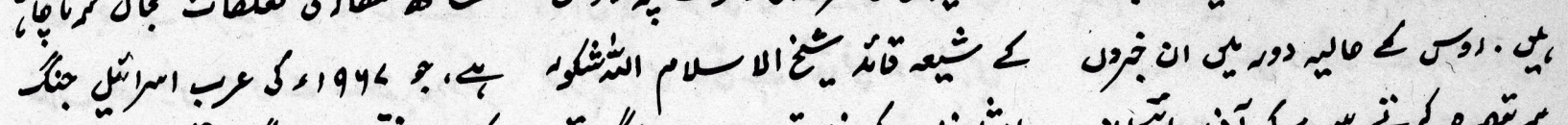

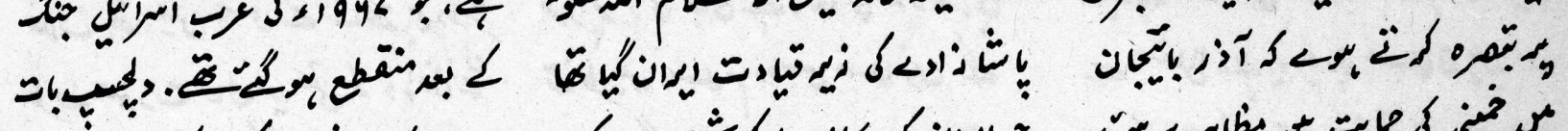

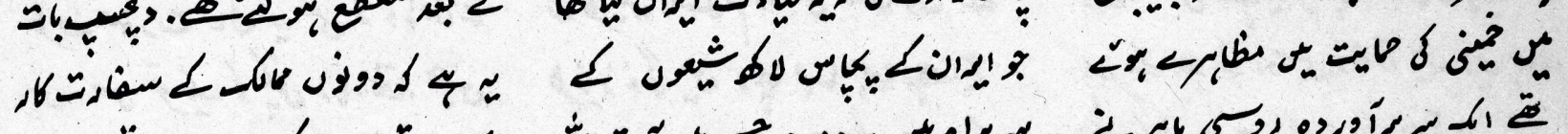

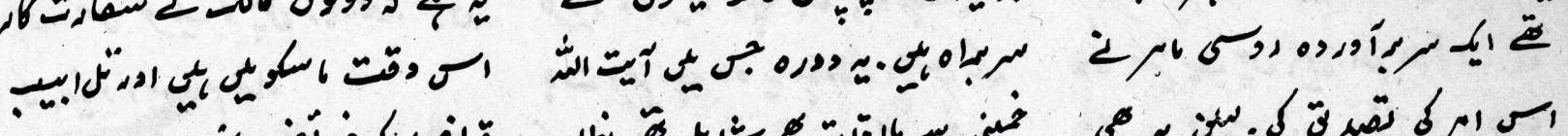

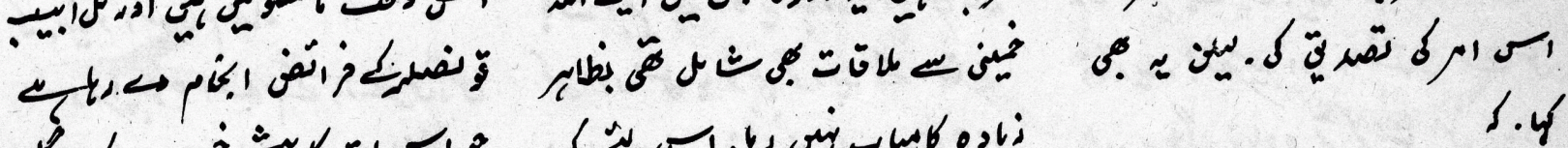

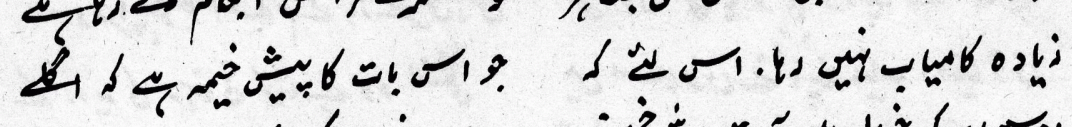

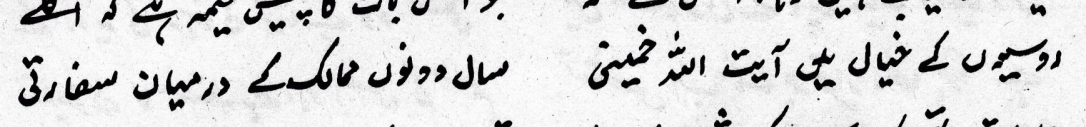

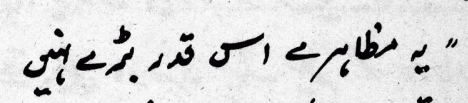

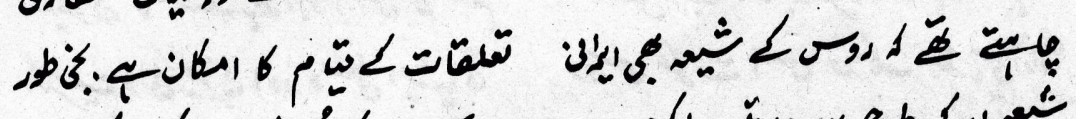

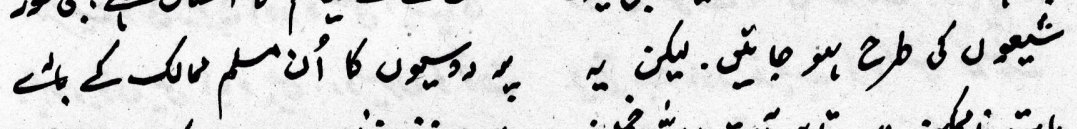
J Jis 政

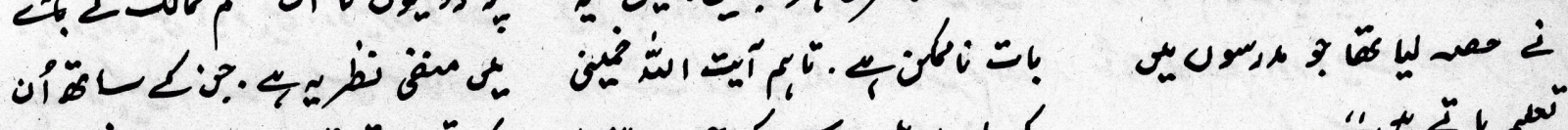

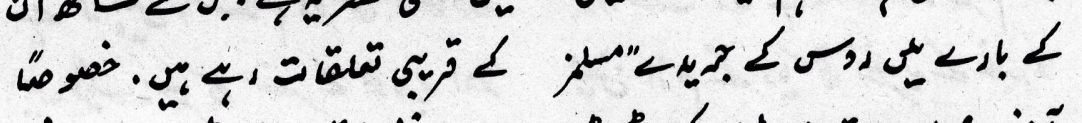

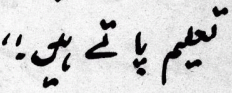

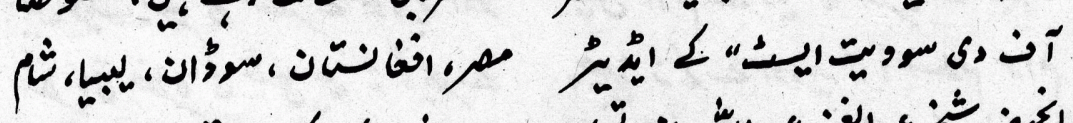
家

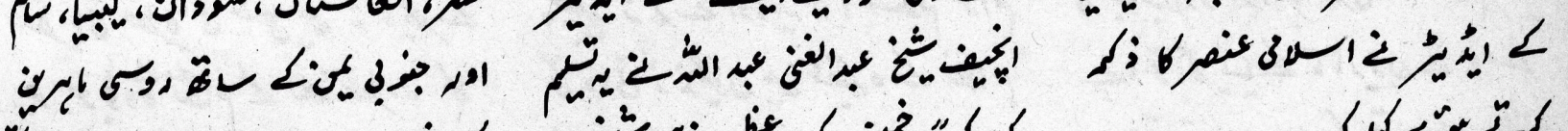

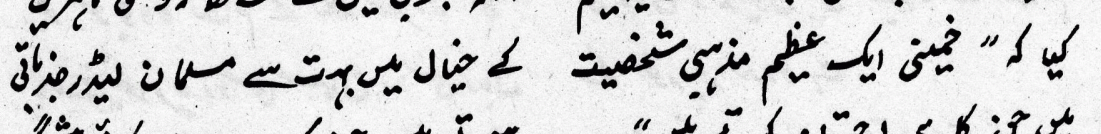

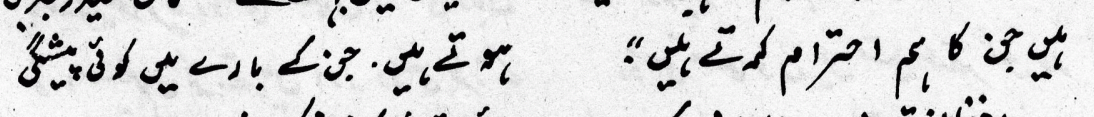

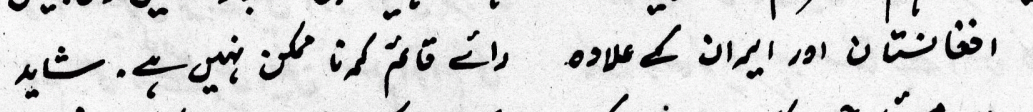

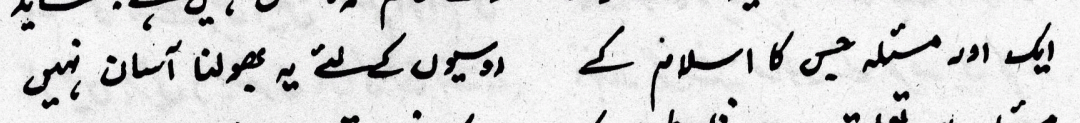

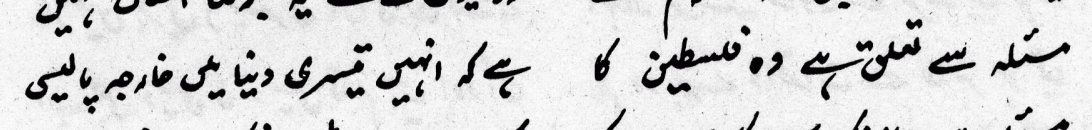

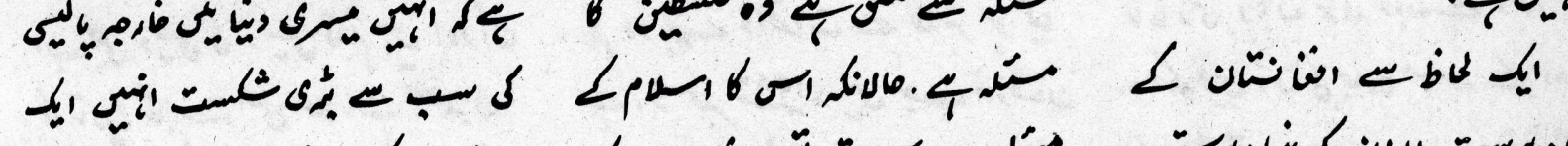

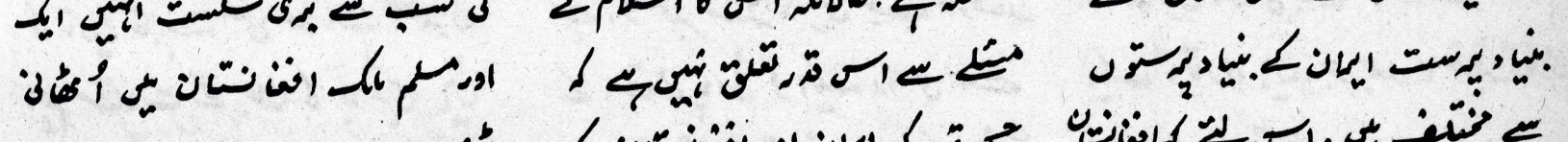

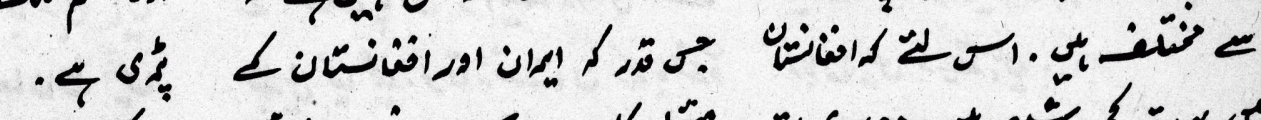

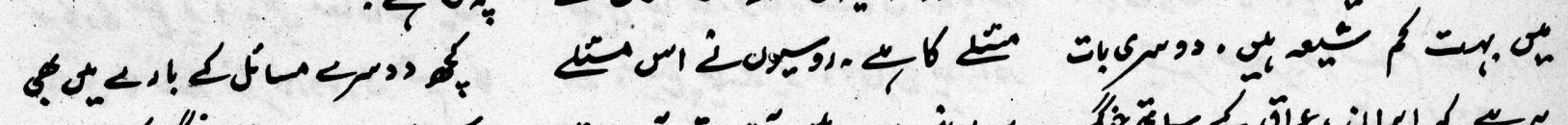

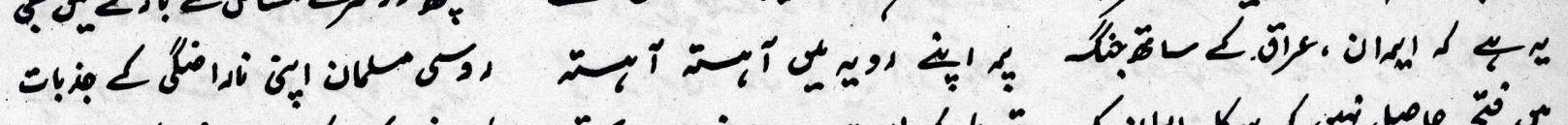

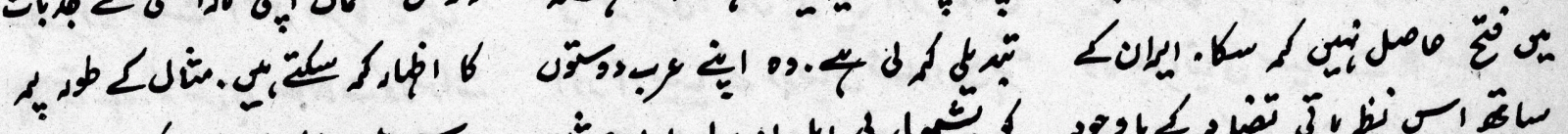

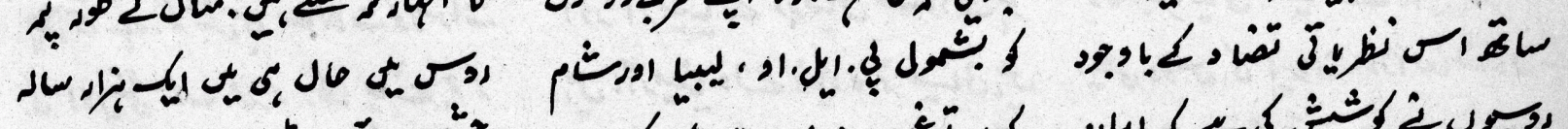

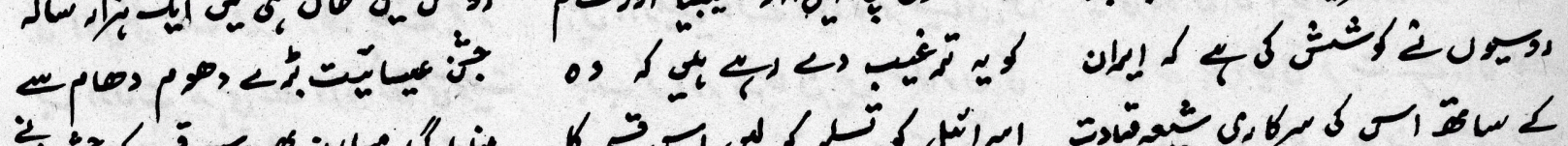

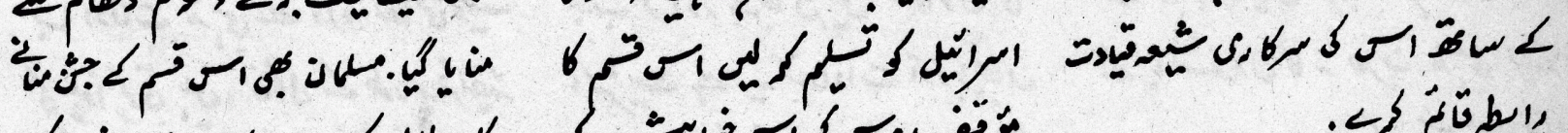

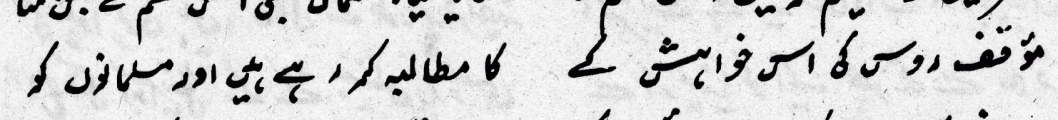

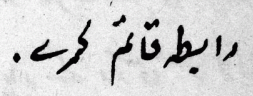

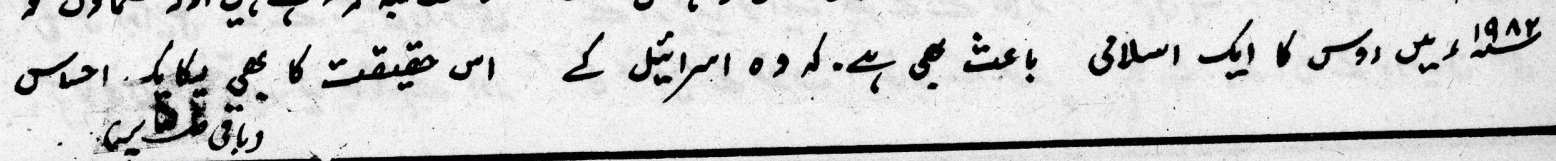


$\Delta 1$

26

(يسيواحهبدشاه مسنّم)

:

"

๘"

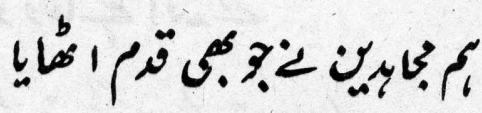

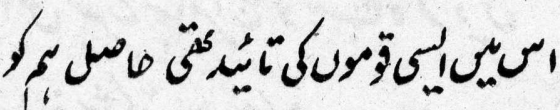

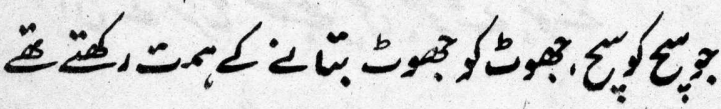

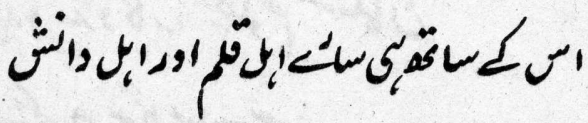

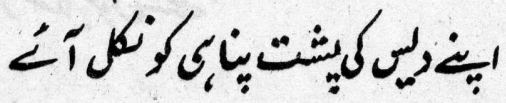

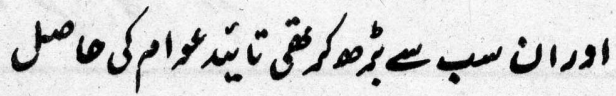

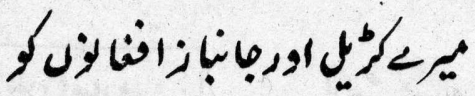

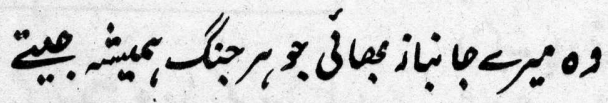

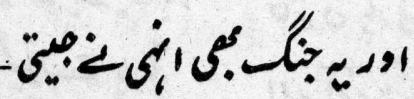

:
اب

جن

6.

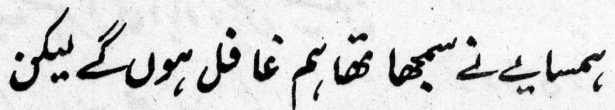

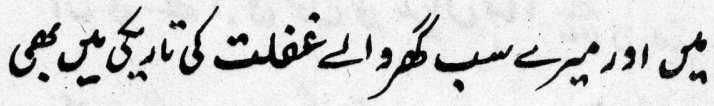

-

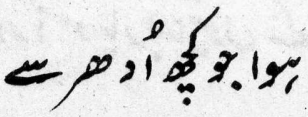

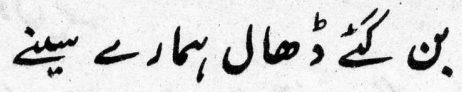

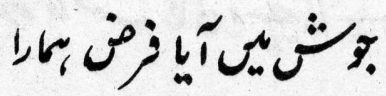

:

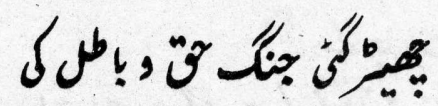

S

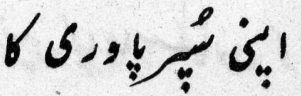

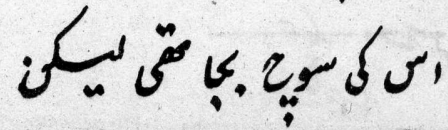


बi

Dr

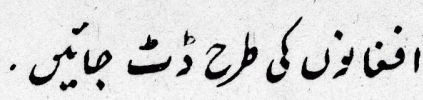

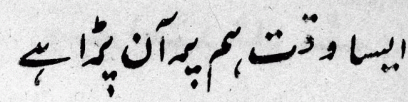

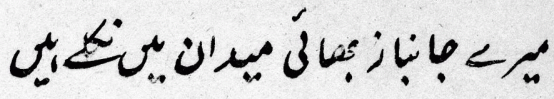

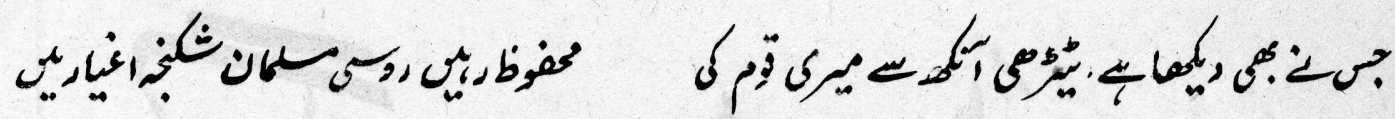

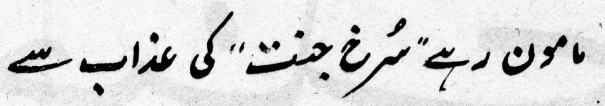

Ii

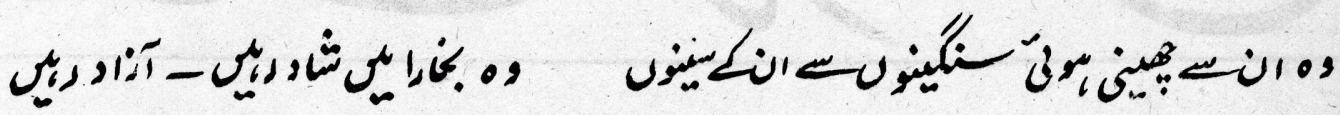

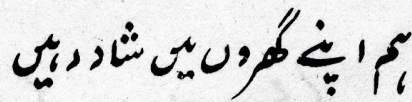

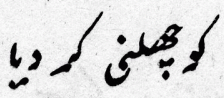

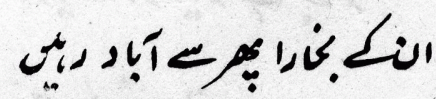

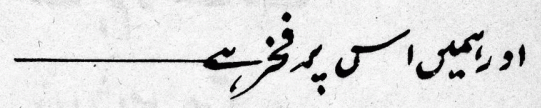

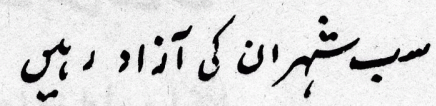

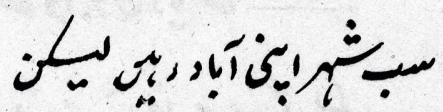

ئسبs

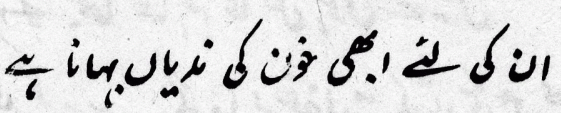

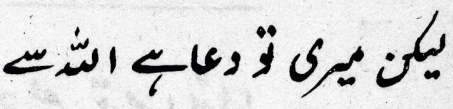

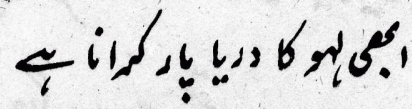

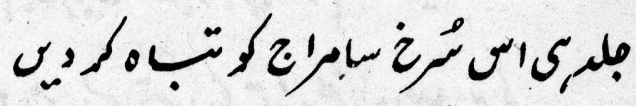

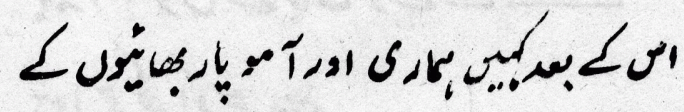

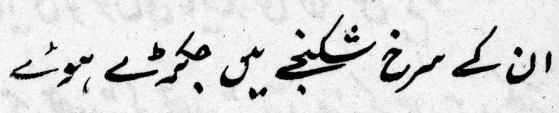

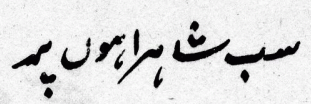

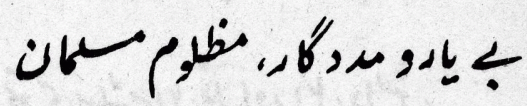

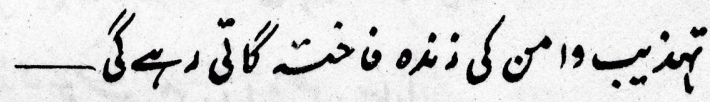

كناس

1 1

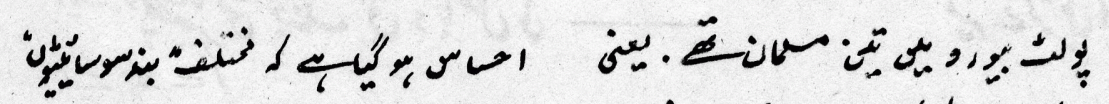

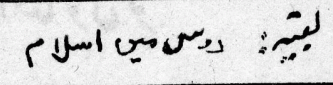

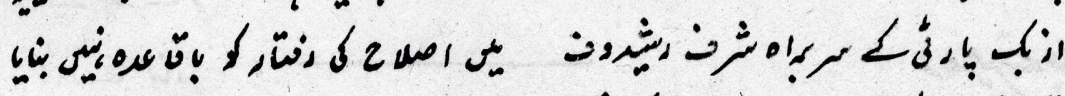

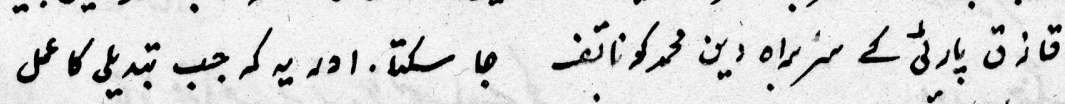

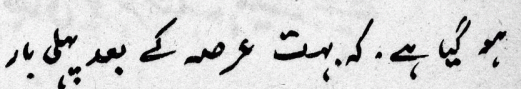

年

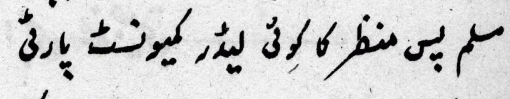

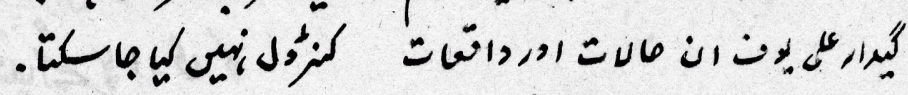

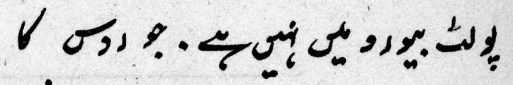

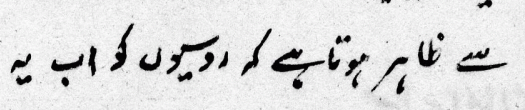

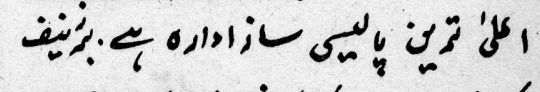

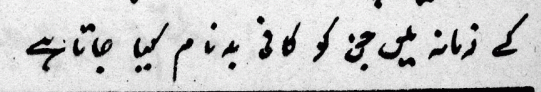


$\Delta r$

$\simeq 6$

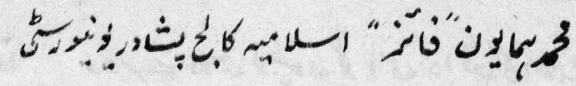

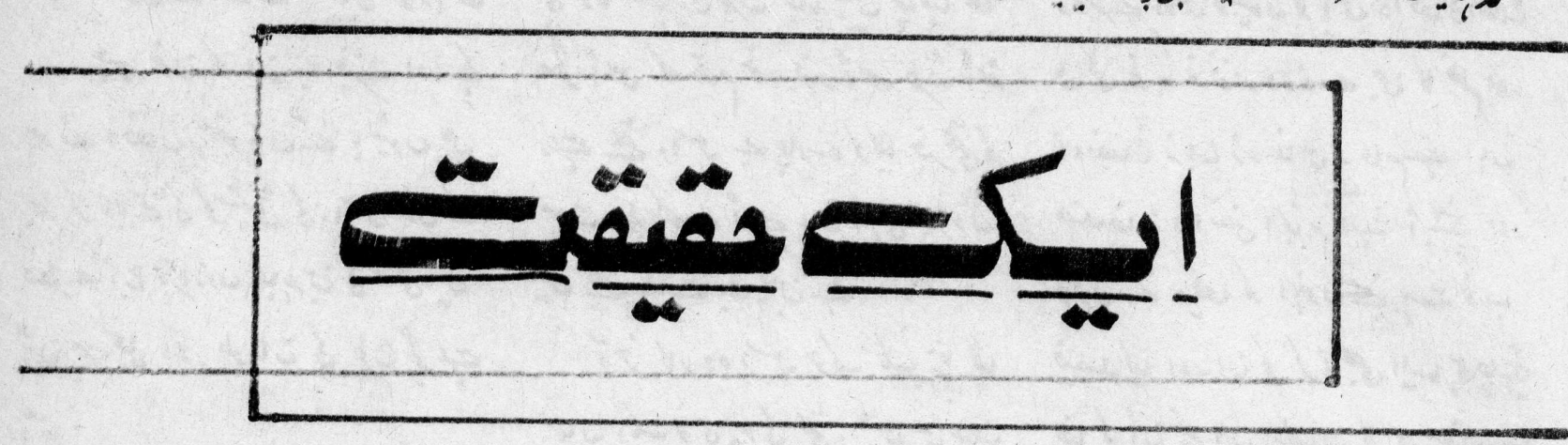

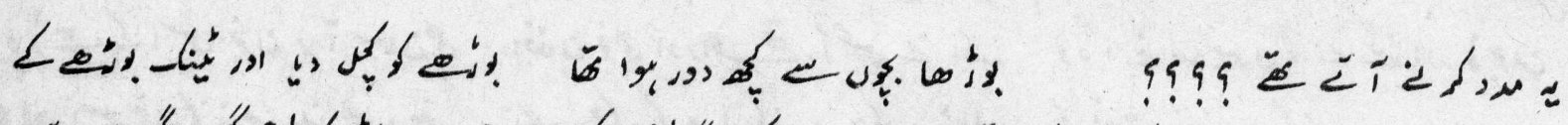

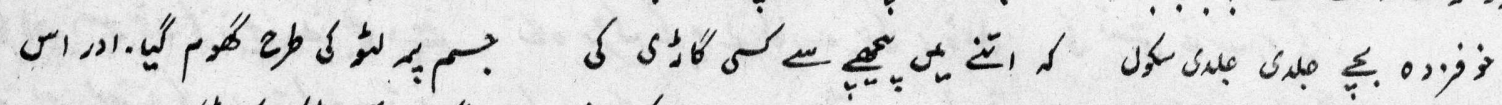

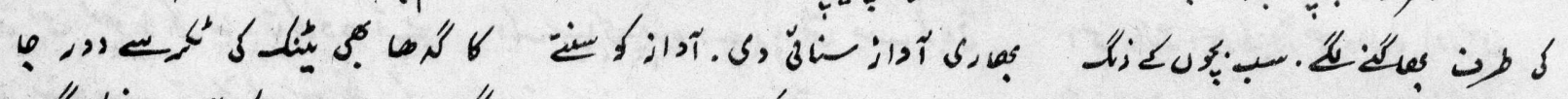

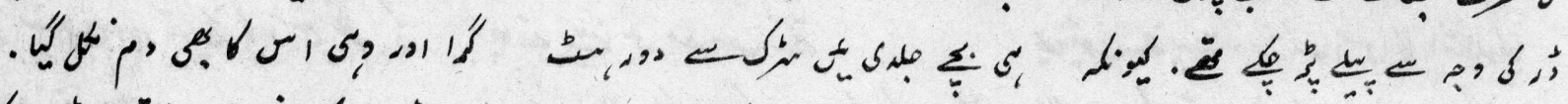

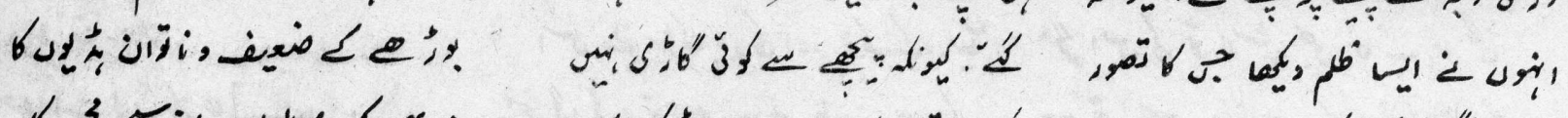

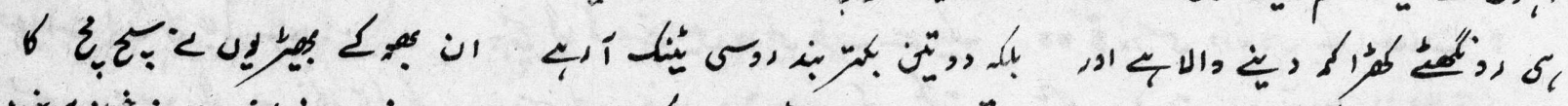

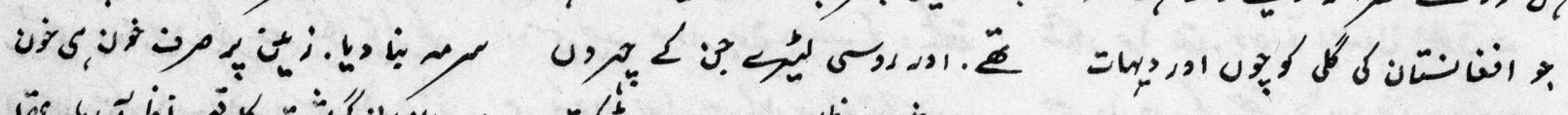

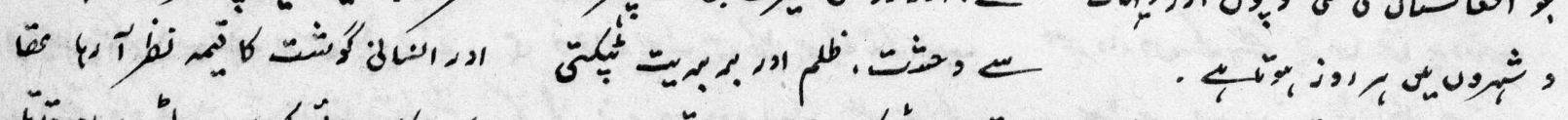

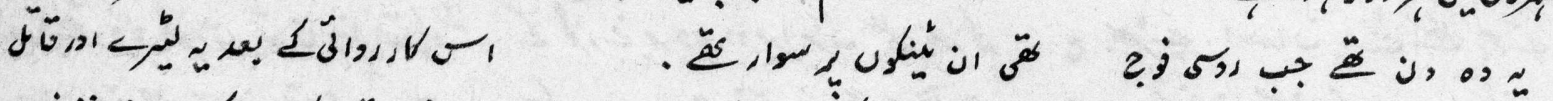

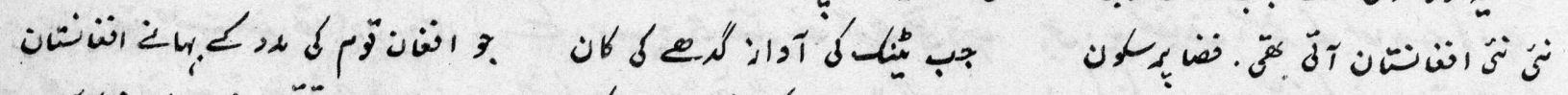

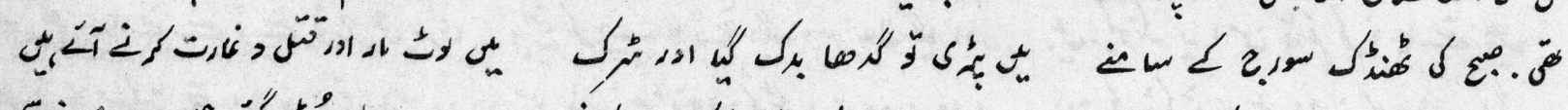

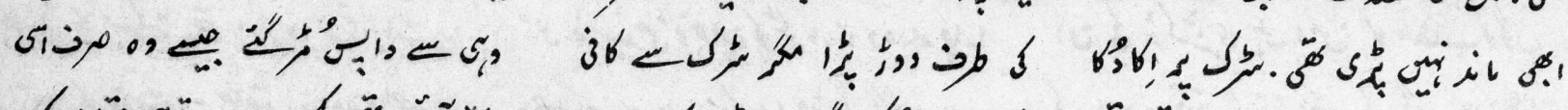

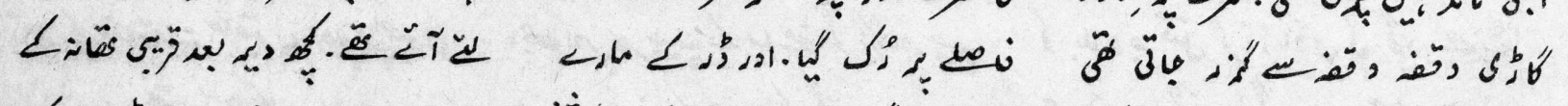

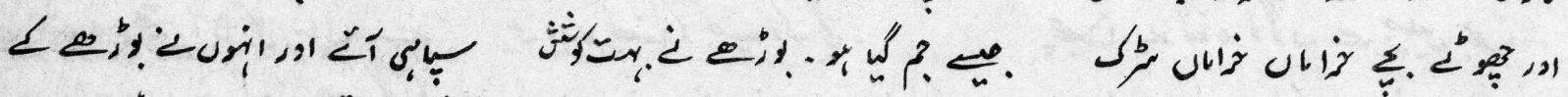
若

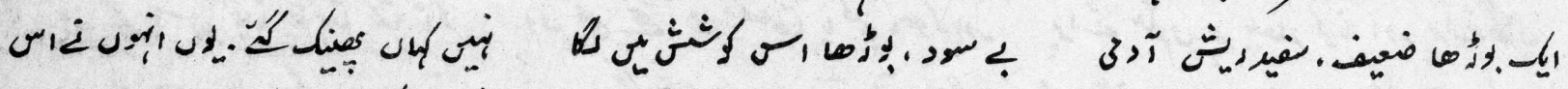

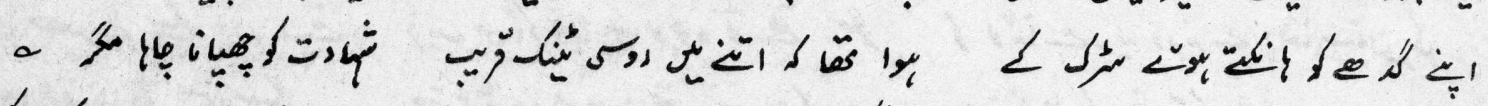

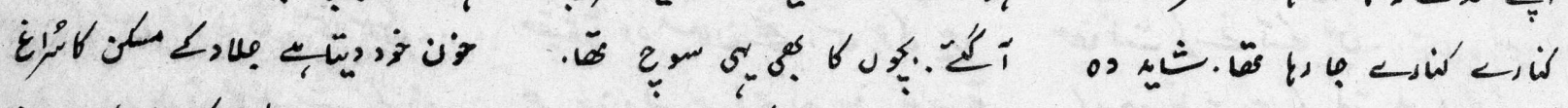
ن

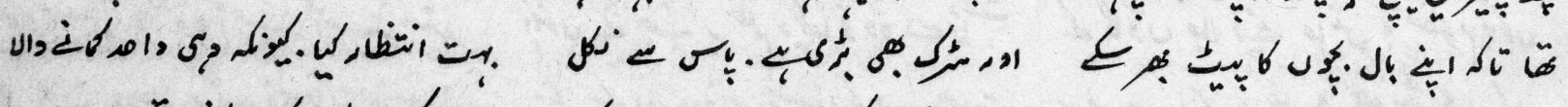

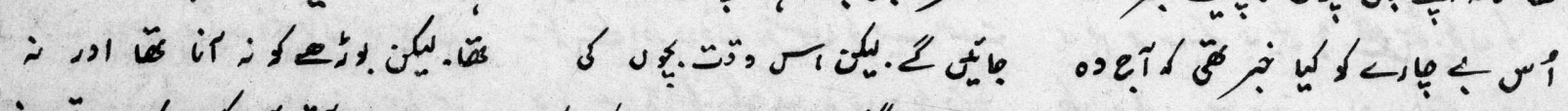

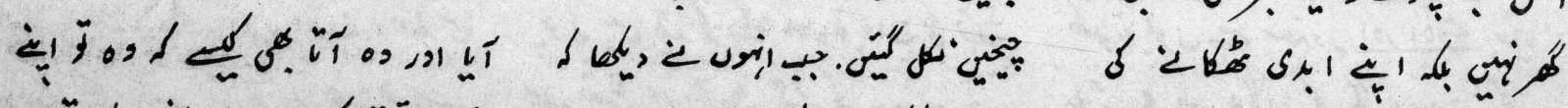

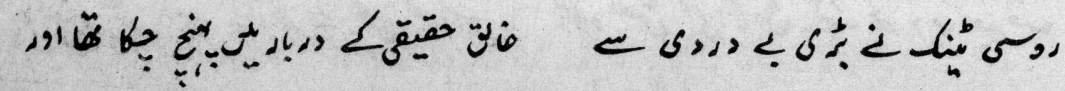

$-41, \div \div 5$ 
$\subseteq \varepsilon^{\circ}$

$\Delta N$

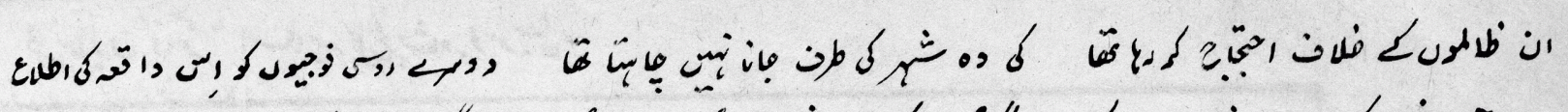

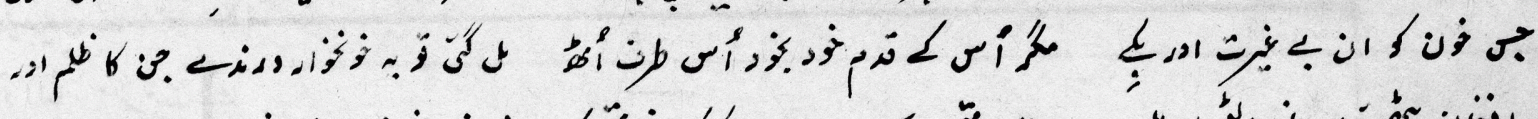

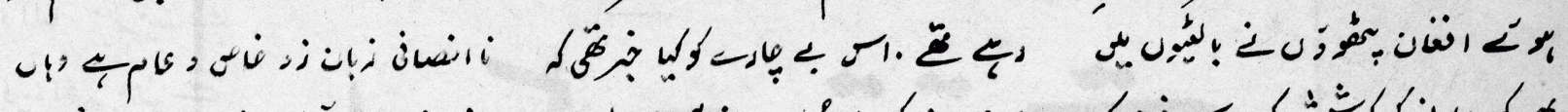

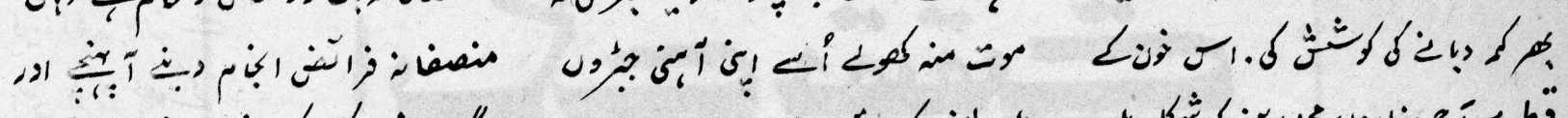

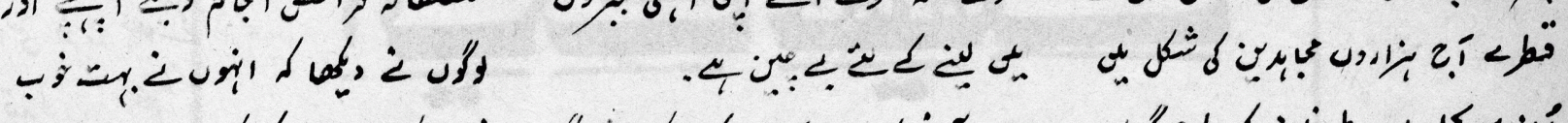

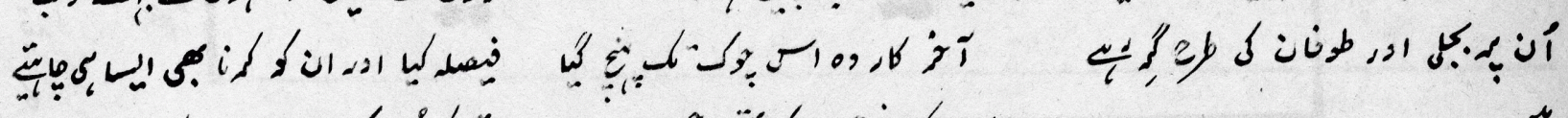

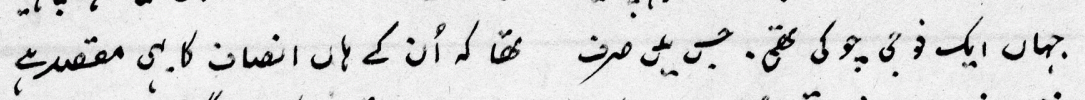

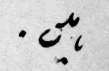

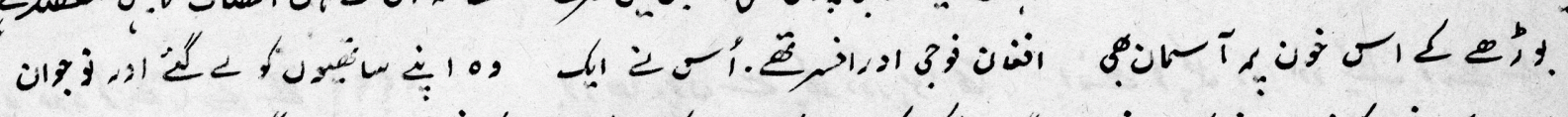

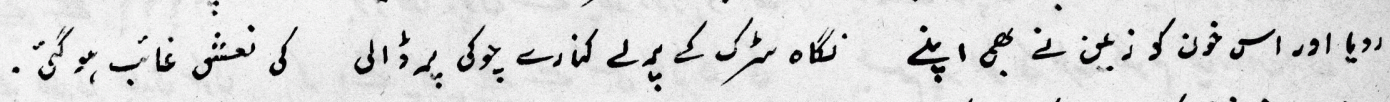
管

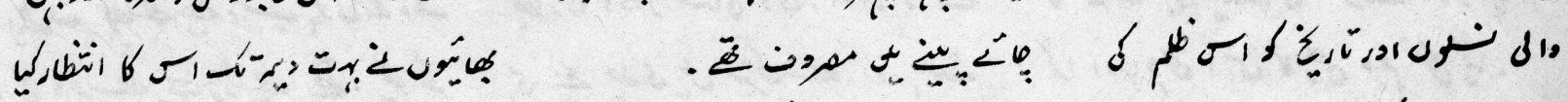

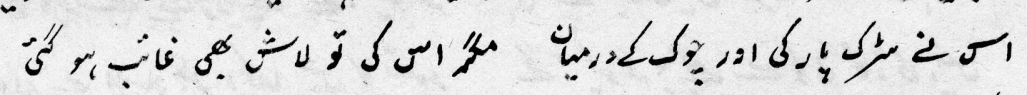

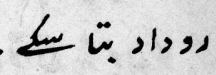

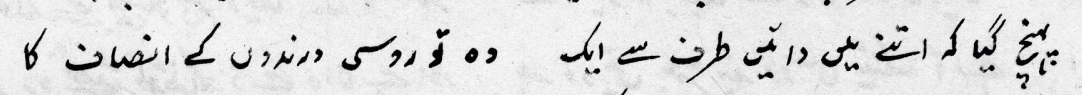

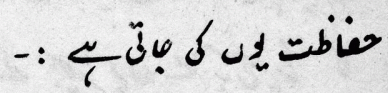

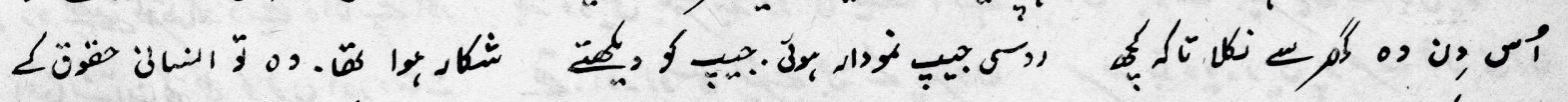

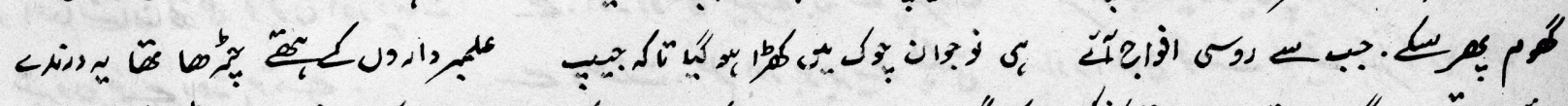

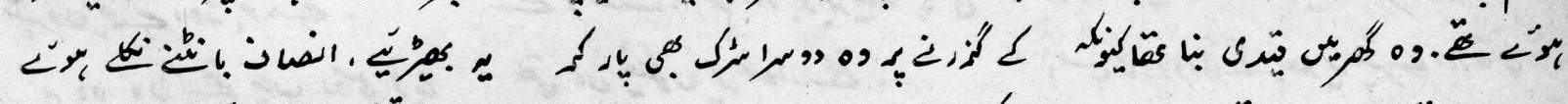

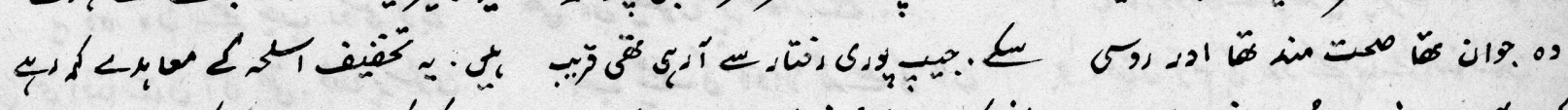

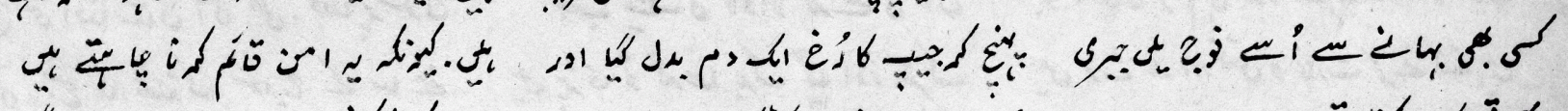

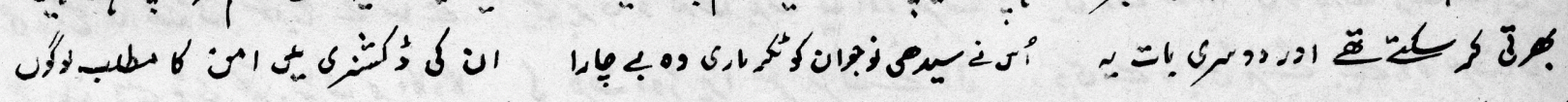

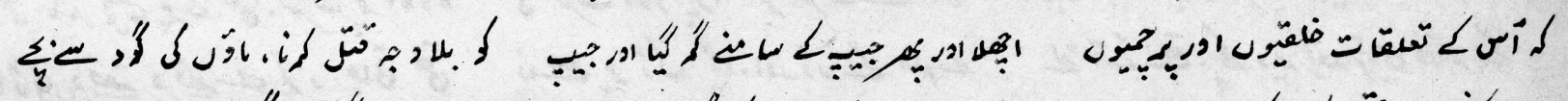

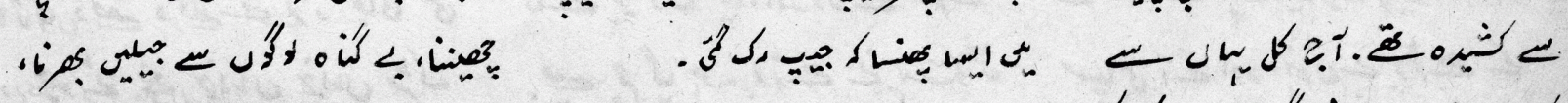

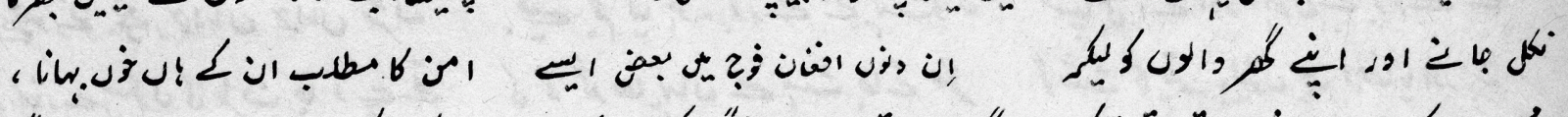

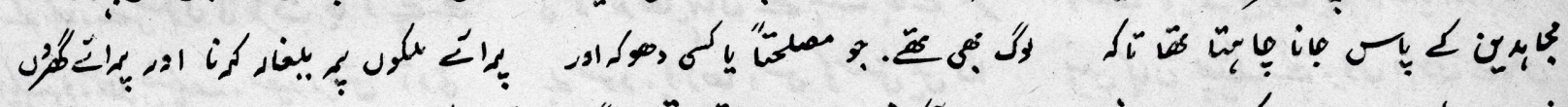
J

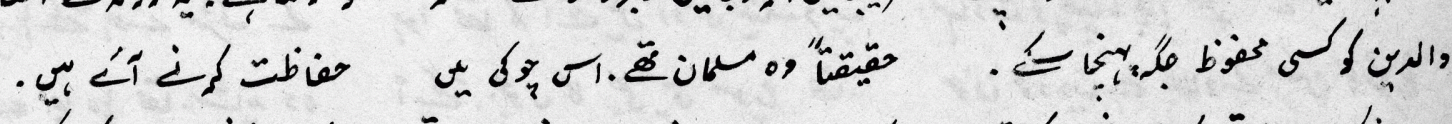

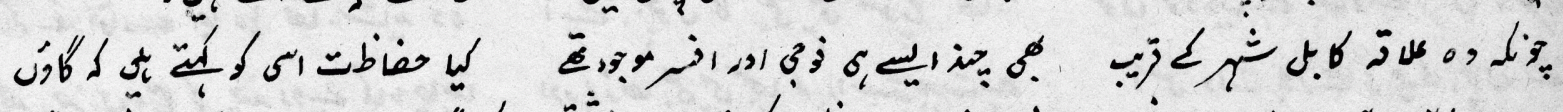

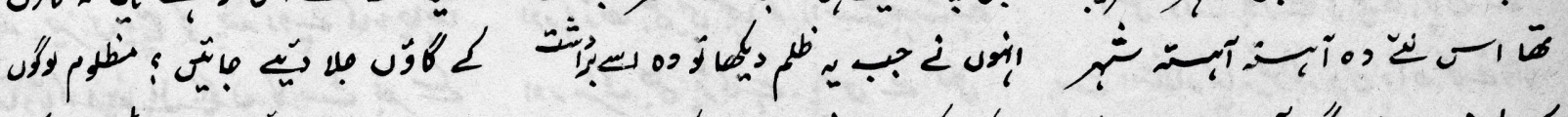

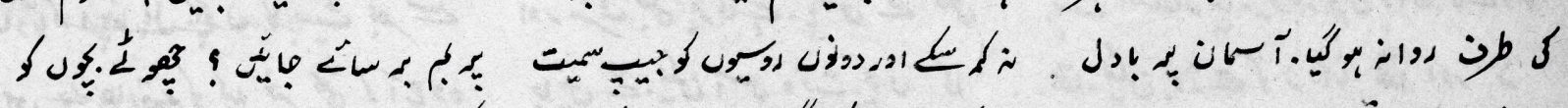
战

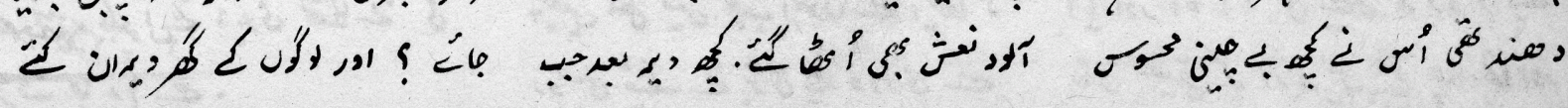


ط أكُرعابد مستص

\section{روسُجارحيّتكانيا انداز}

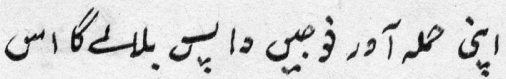

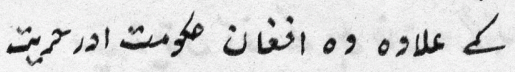

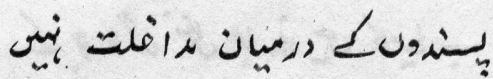

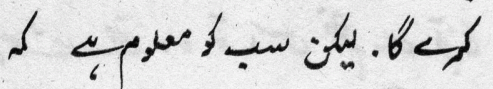

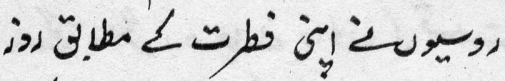

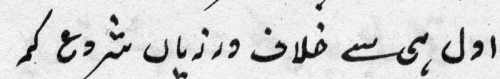

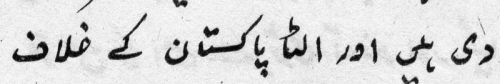

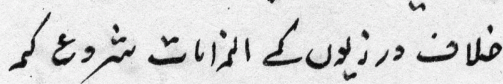

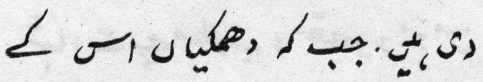

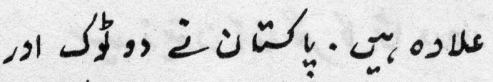

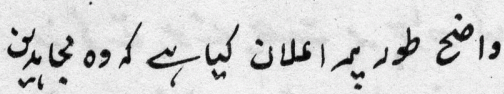

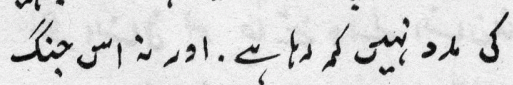

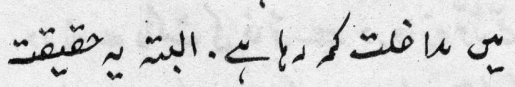

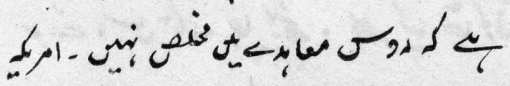

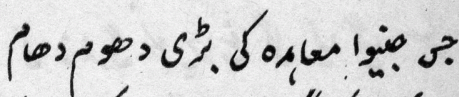
ع

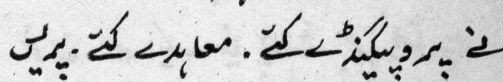

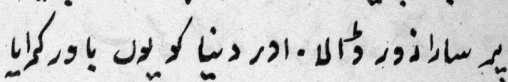

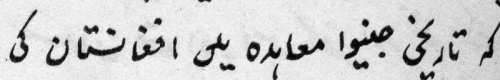

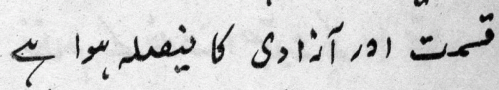

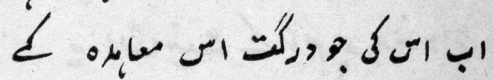

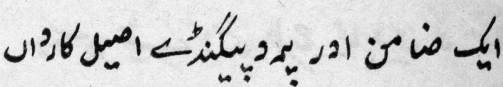

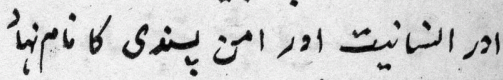

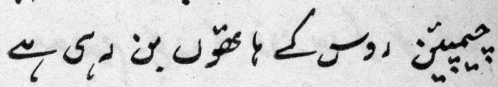

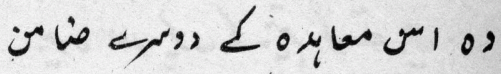

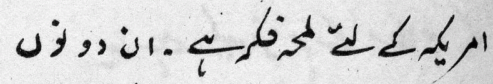
in

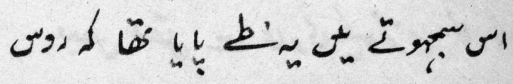

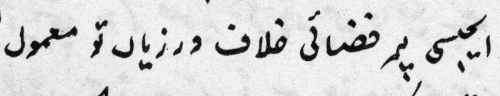
अं

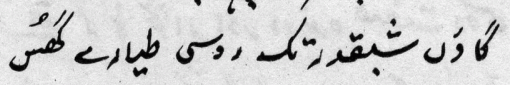

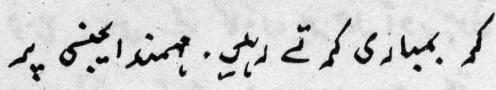

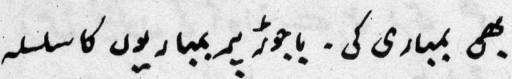

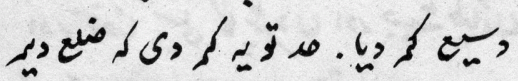
Jivoil

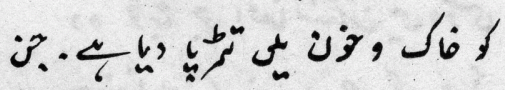

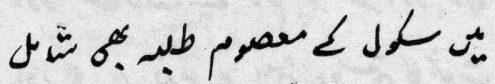

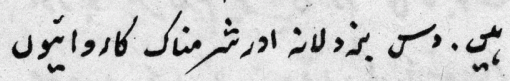

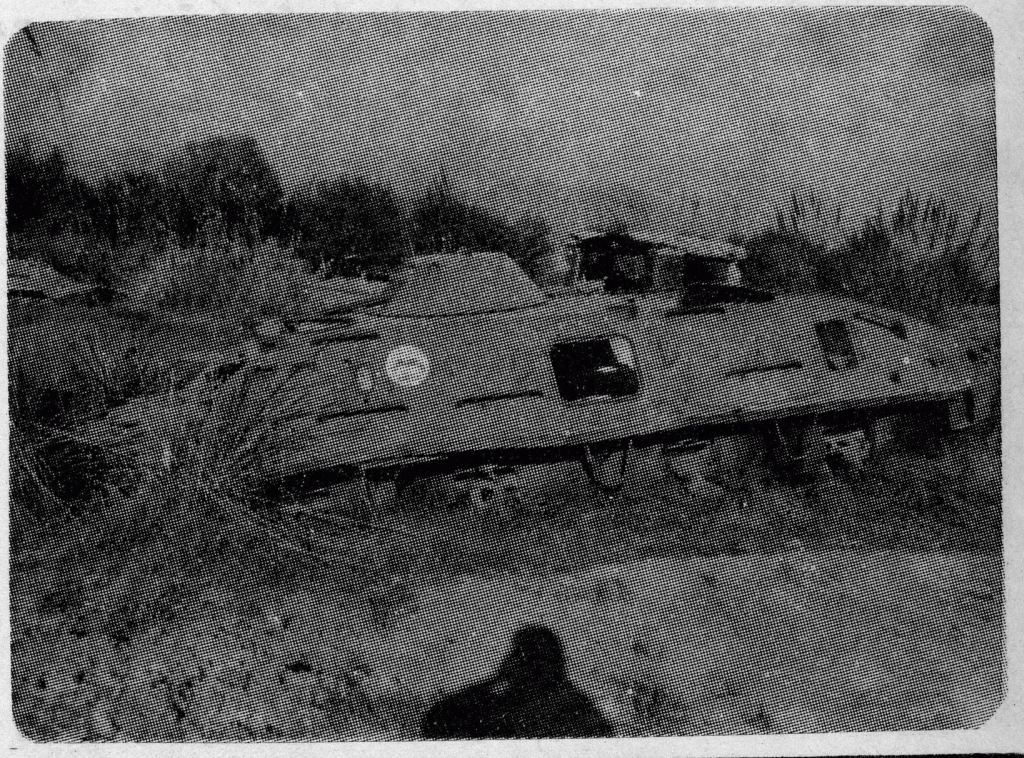


06

"

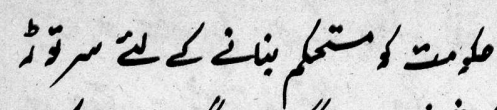

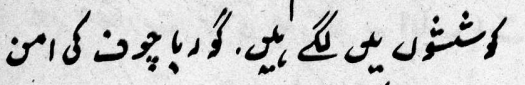

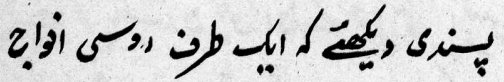

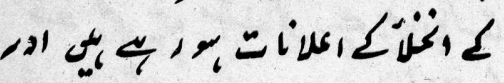
وركي

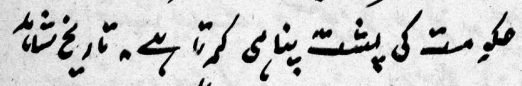

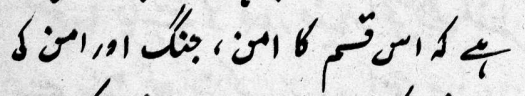

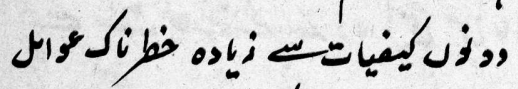

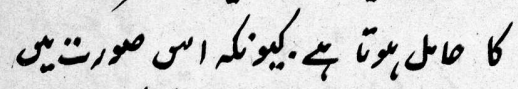

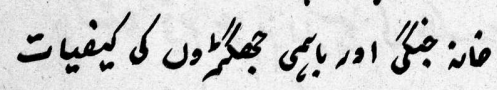

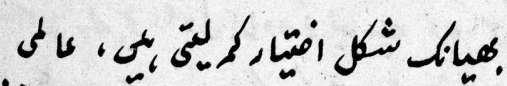

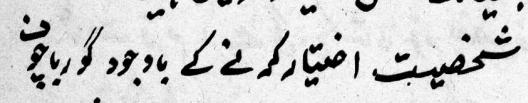

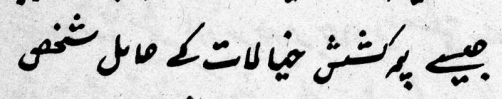

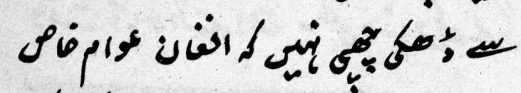

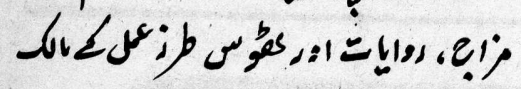

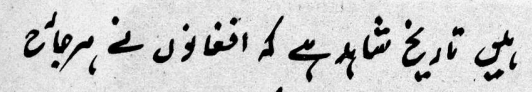

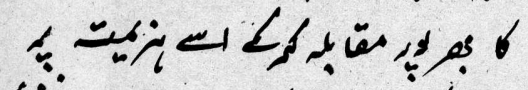

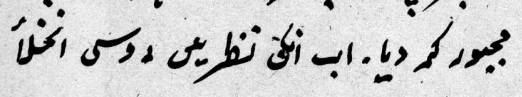

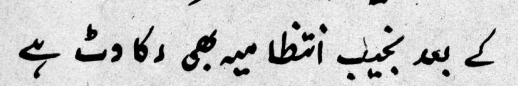

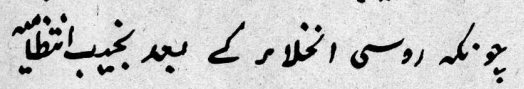

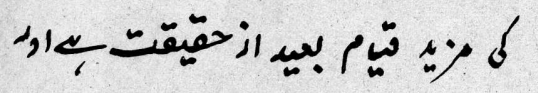

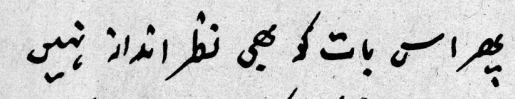

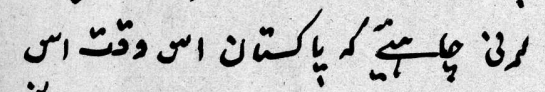

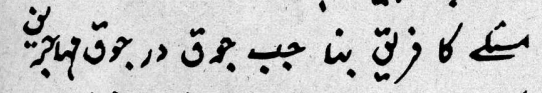

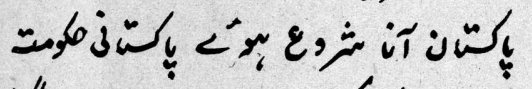
أهر

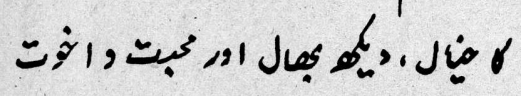

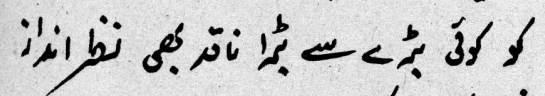
ic ؛

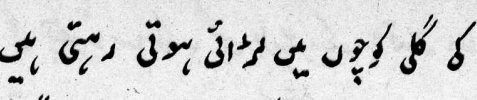

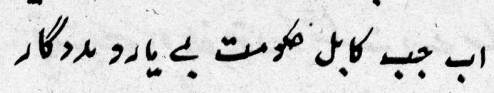

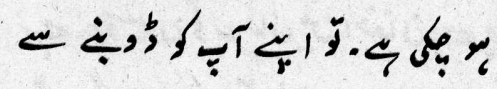

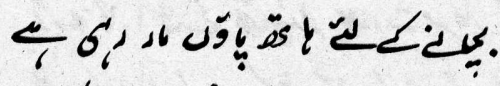

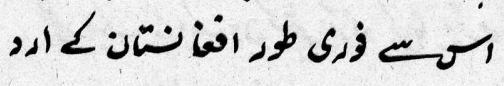

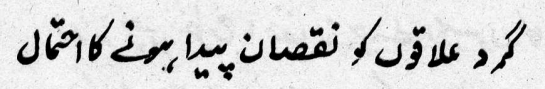

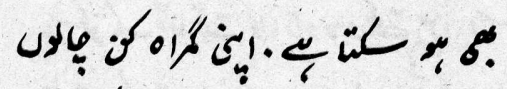

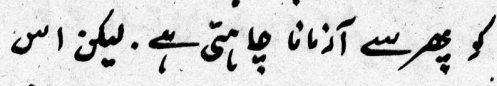

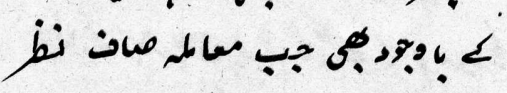

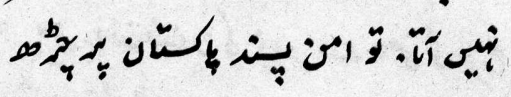

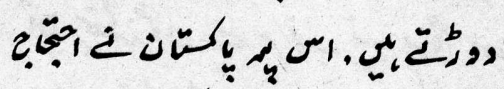

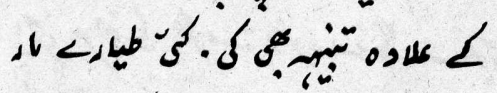
.

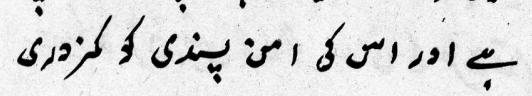

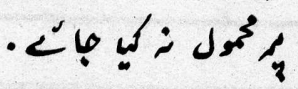

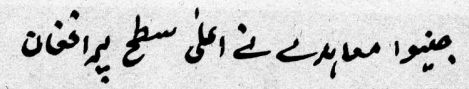

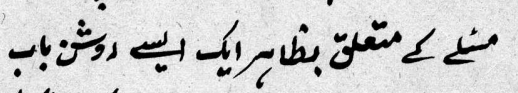

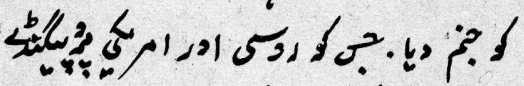

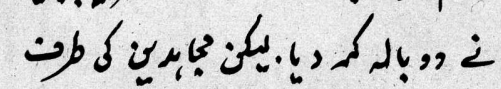
草

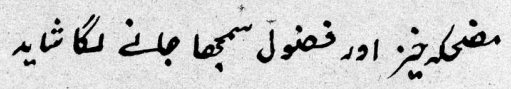

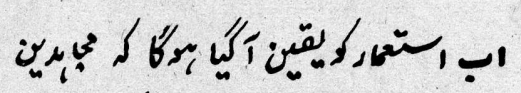

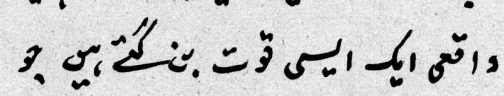

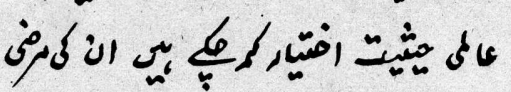

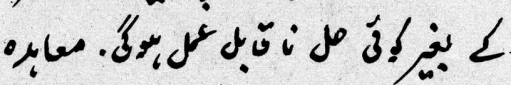

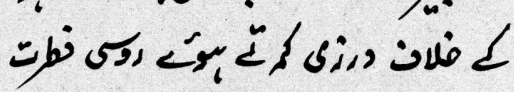

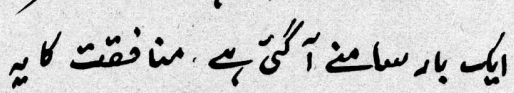

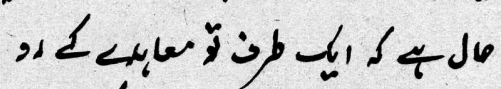

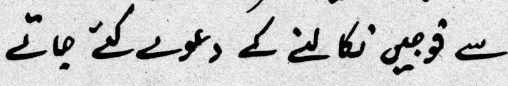

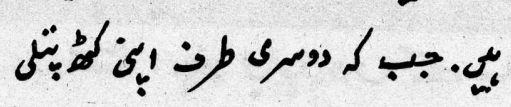

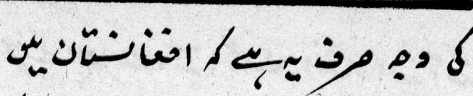
ل أمثز

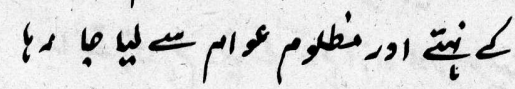
ن

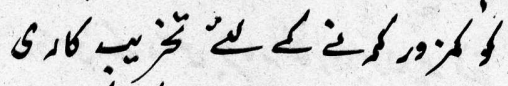

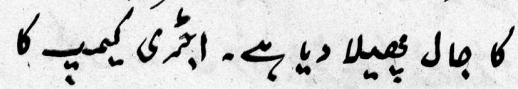

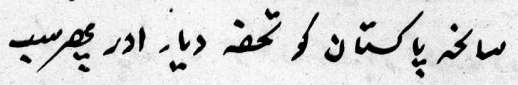

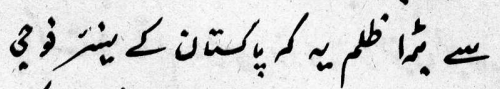

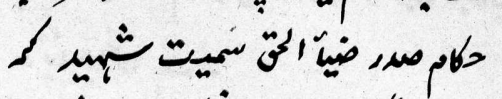
له

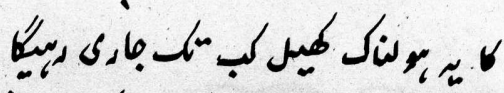

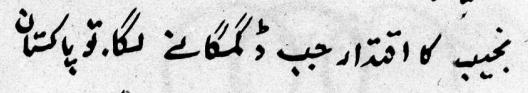

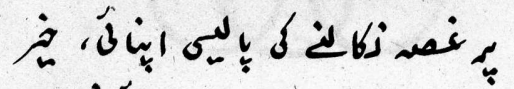

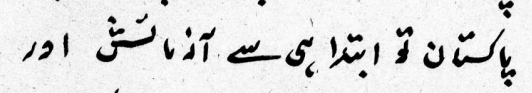

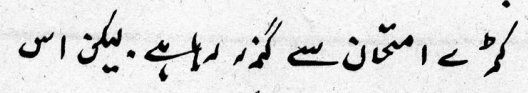

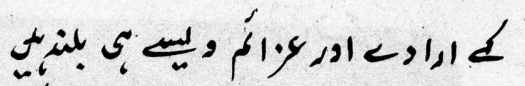

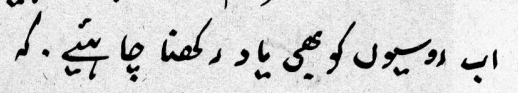

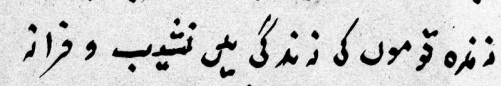

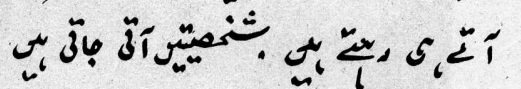

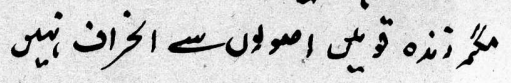

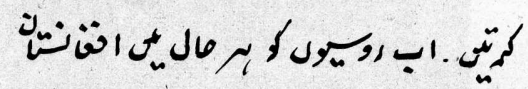

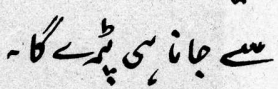

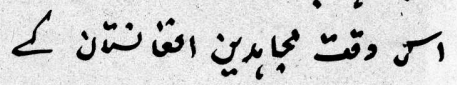

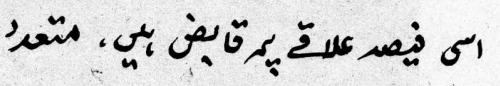

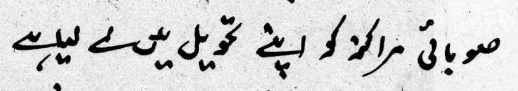

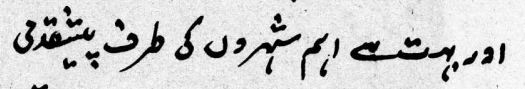

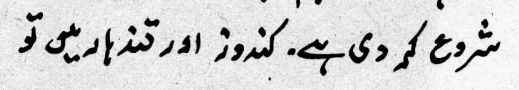

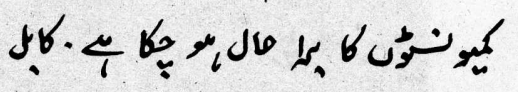

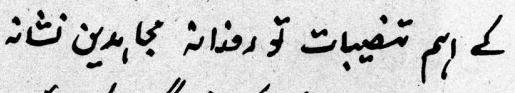

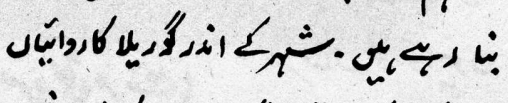

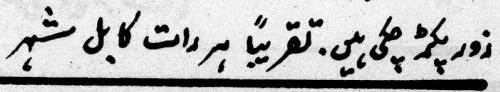




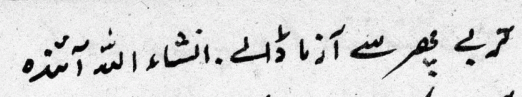

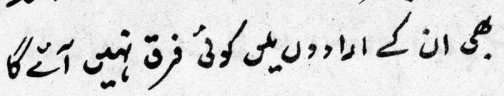
若

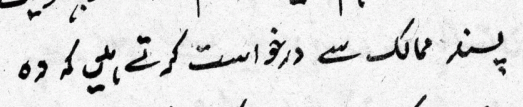

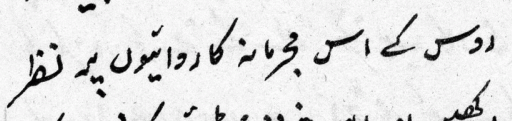

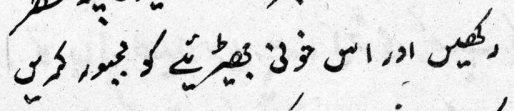

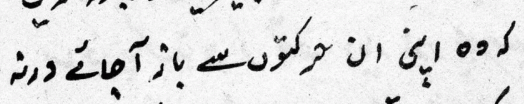

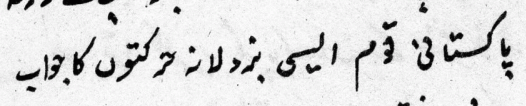

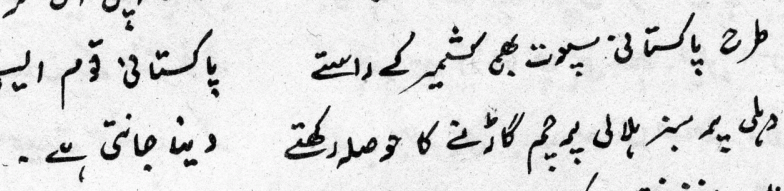

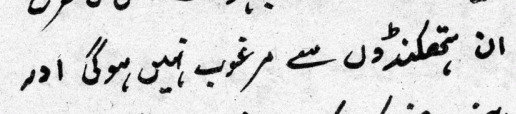

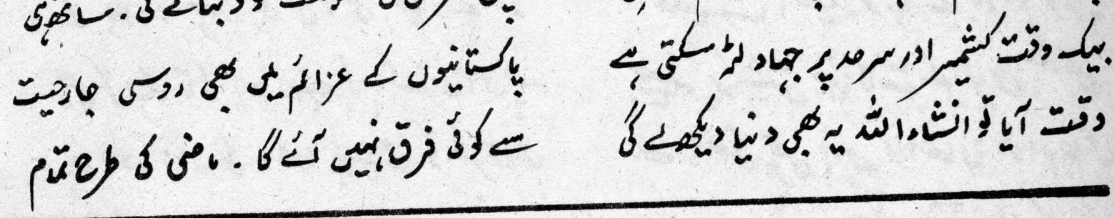

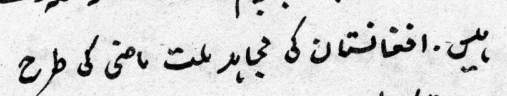

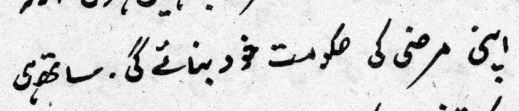

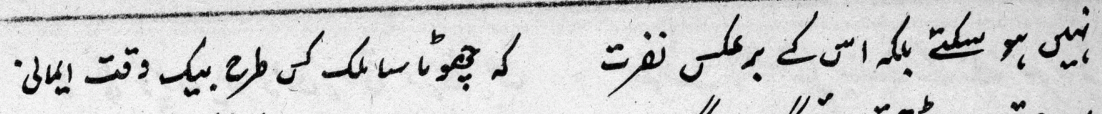

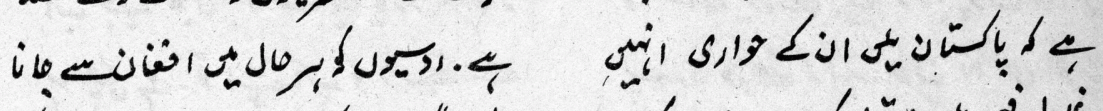

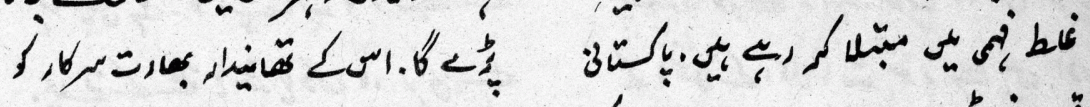

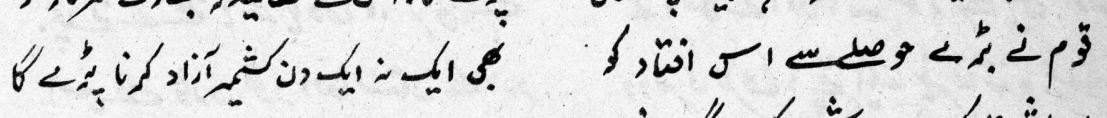

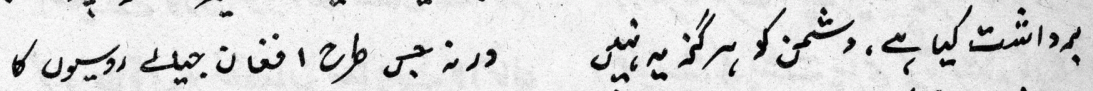

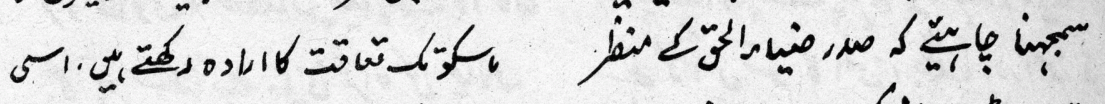
ل . $<<$

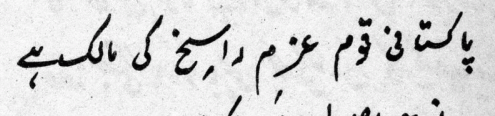
أب

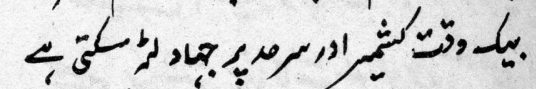

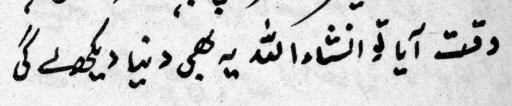

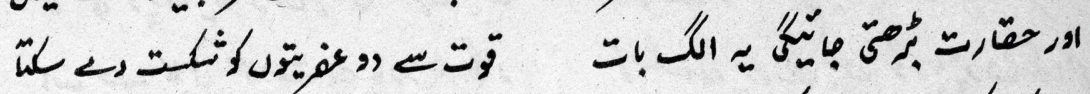

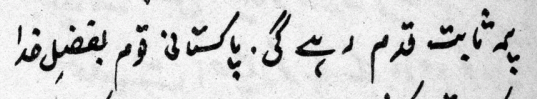

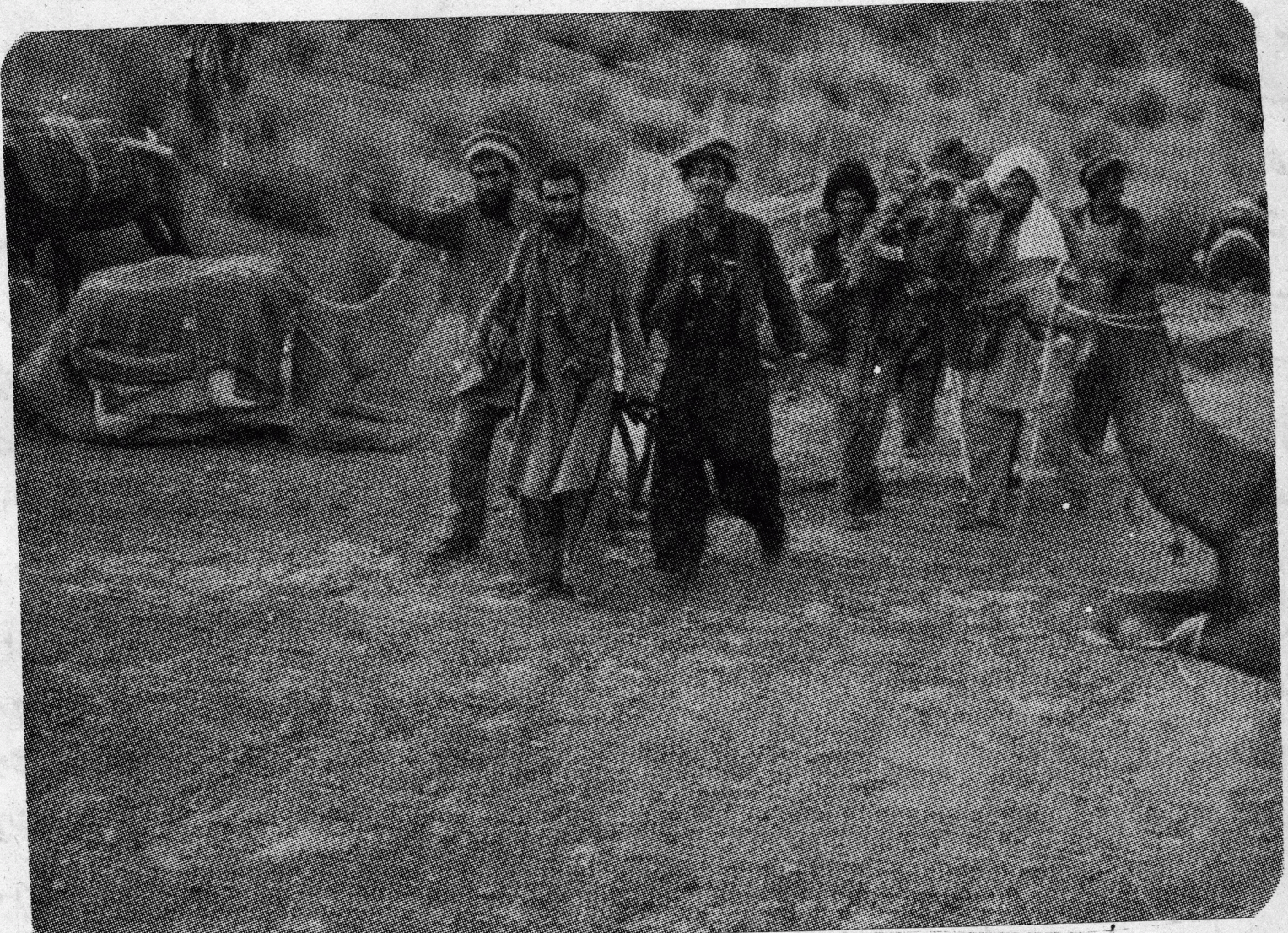

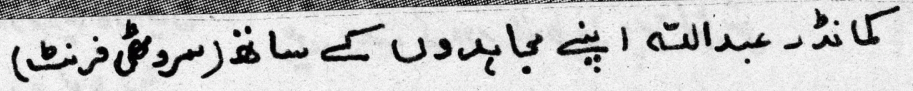




\section{إِنَبِ بِ}

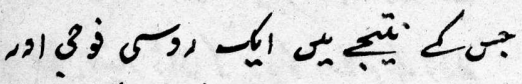

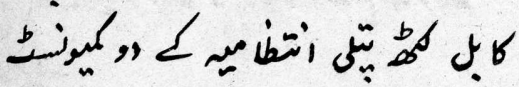

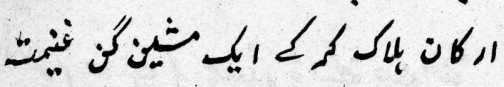

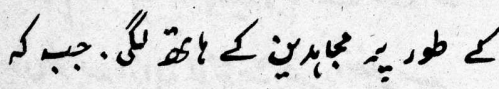

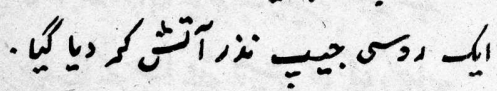

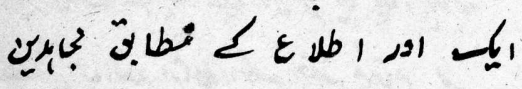
ا

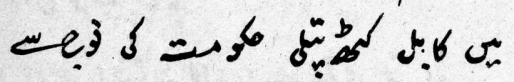

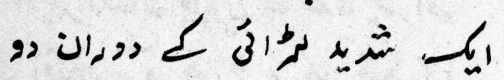

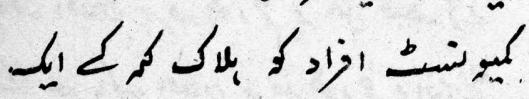

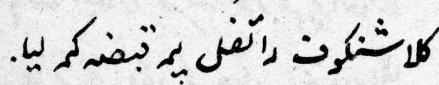

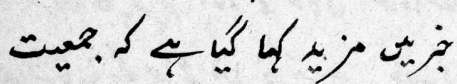

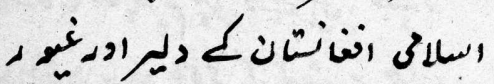

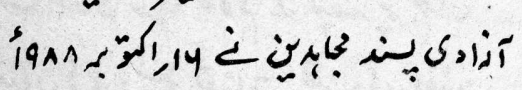

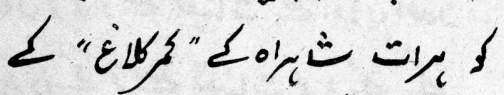

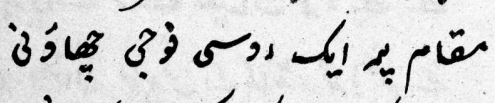
ك ग

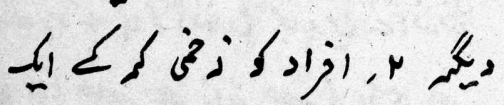

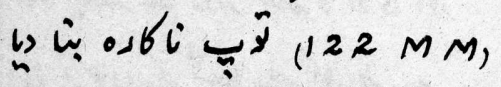
$\div$

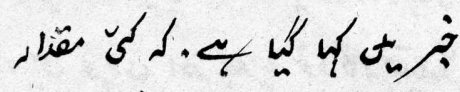

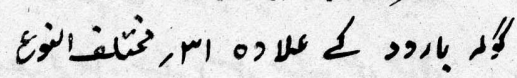

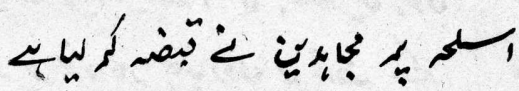

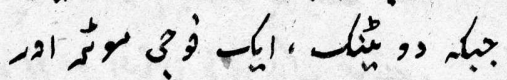

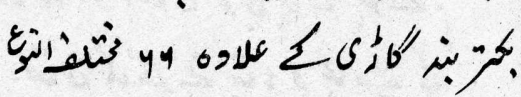

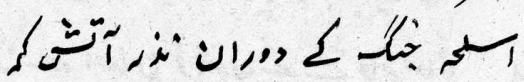
. . 4 네

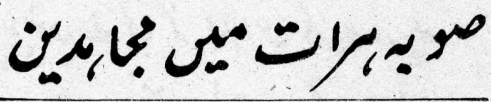
كأك

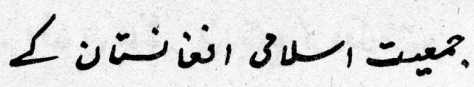
باتيا

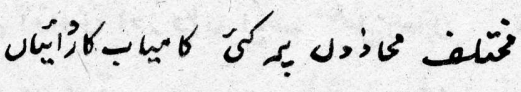

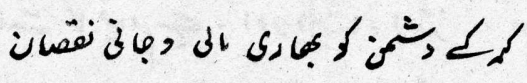
“ مصول بهن

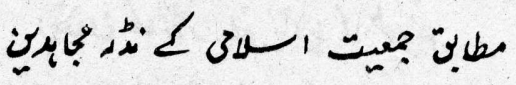

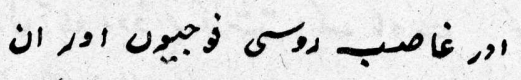

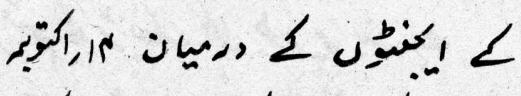

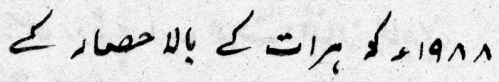

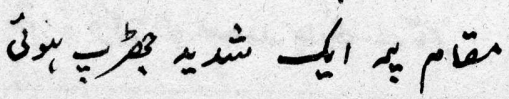

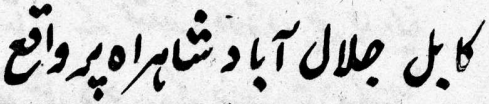

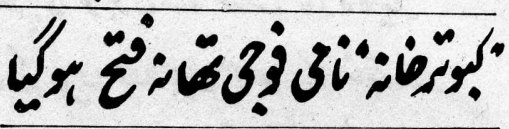
اسر ختثلف النوع السلح

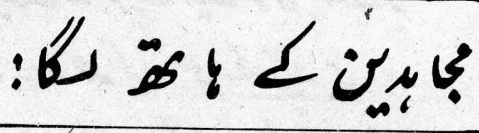

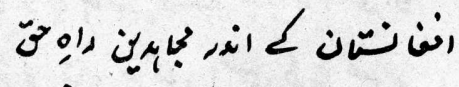

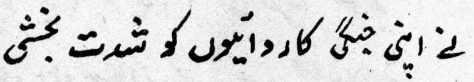

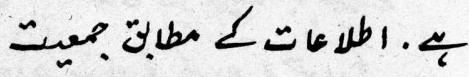

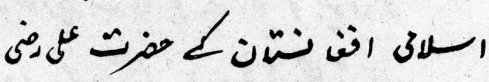

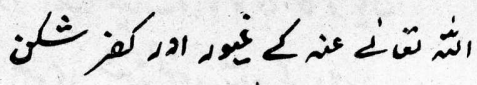

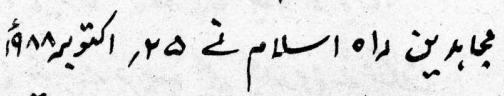

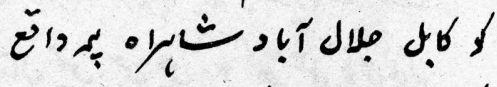

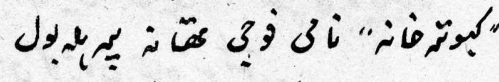

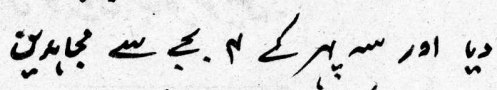

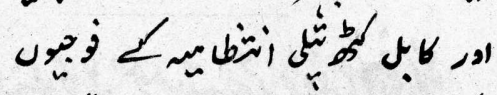

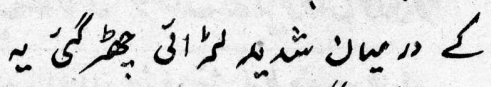

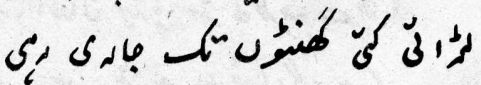

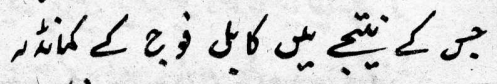

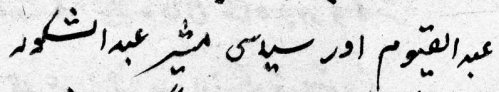

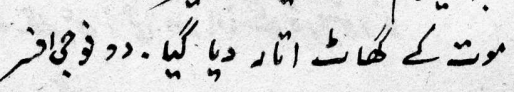

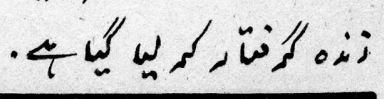


त

Y.

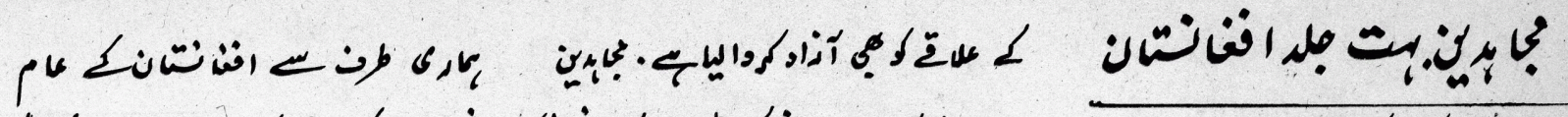

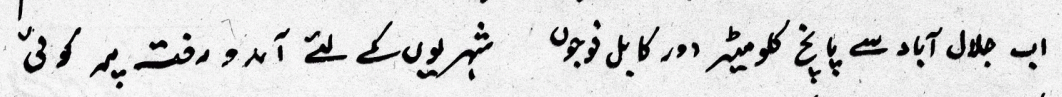

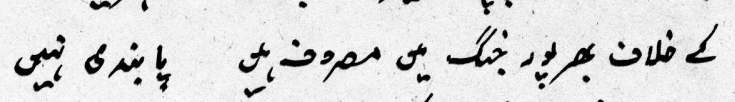

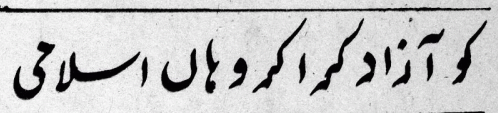

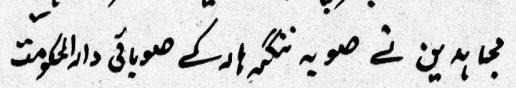

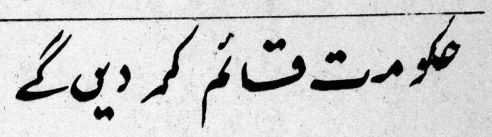

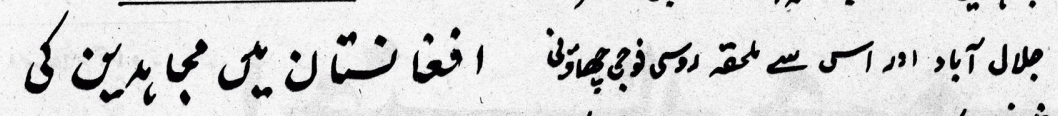
u 定

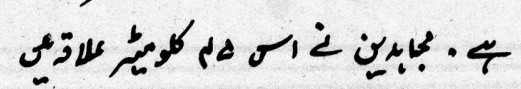

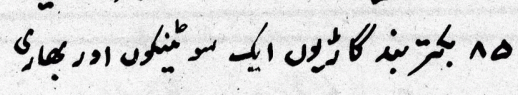

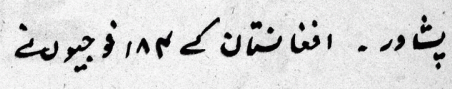
年 (《)

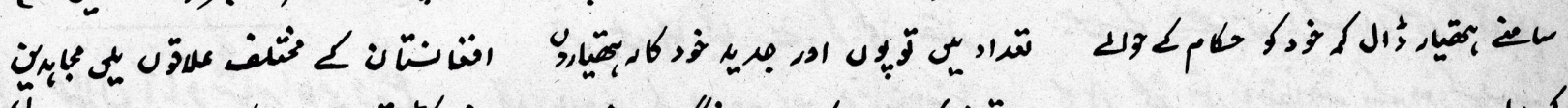
L ك

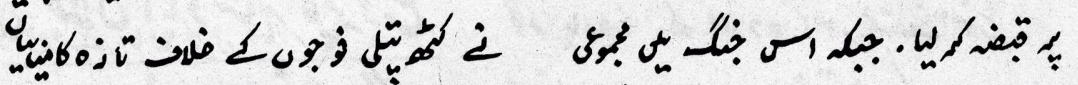

.15

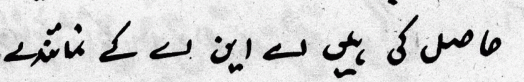

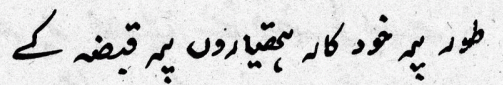

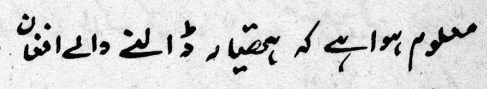

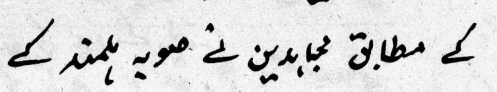

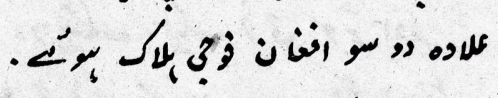

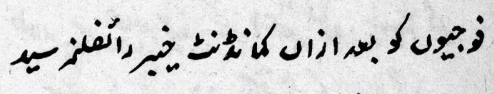

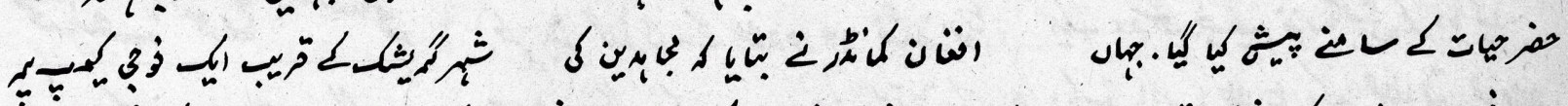

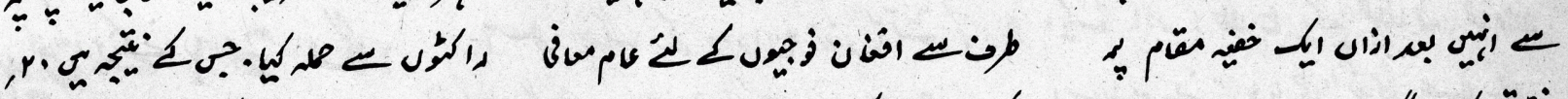

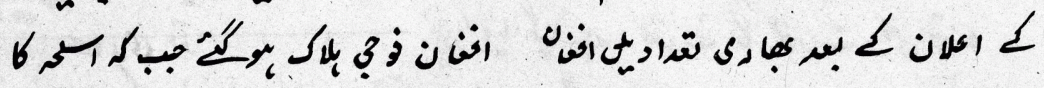

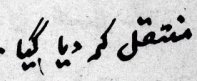

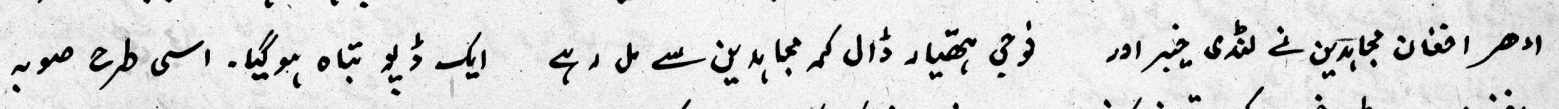

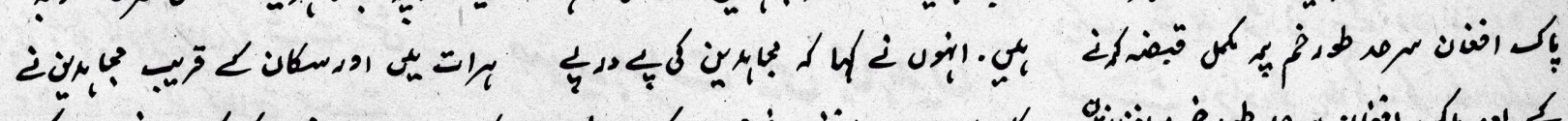

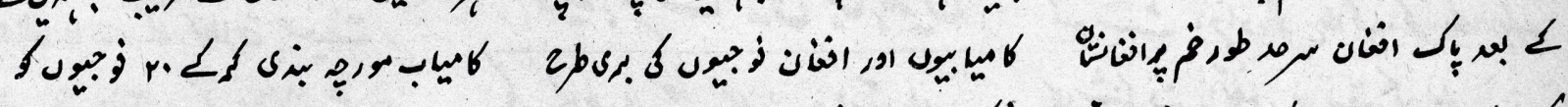
定

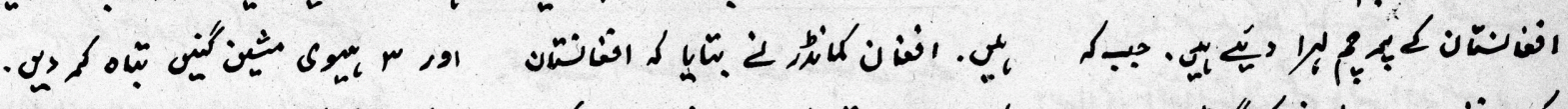

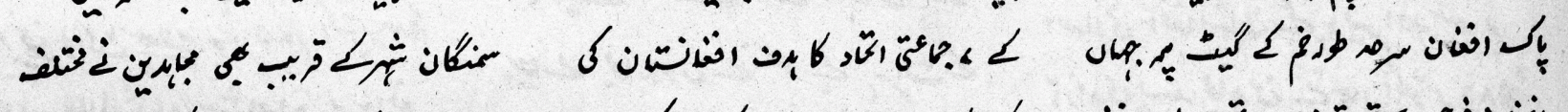

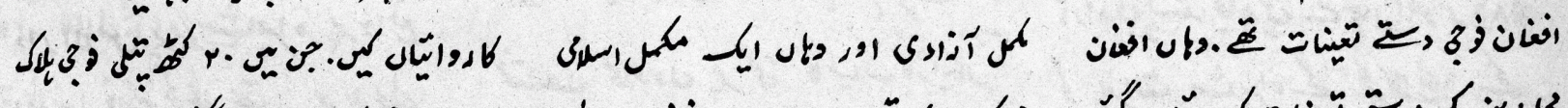

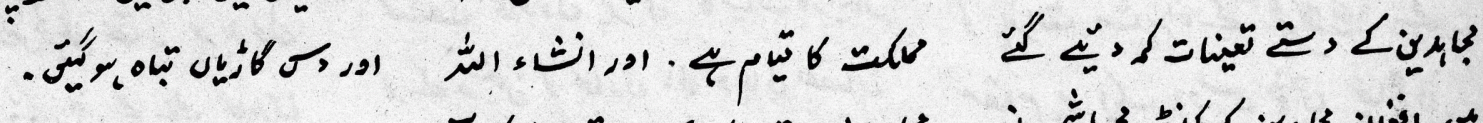

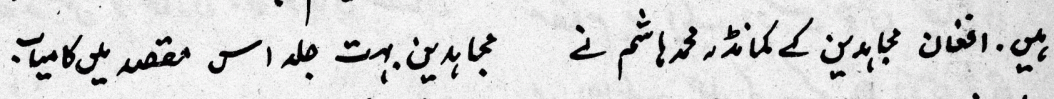

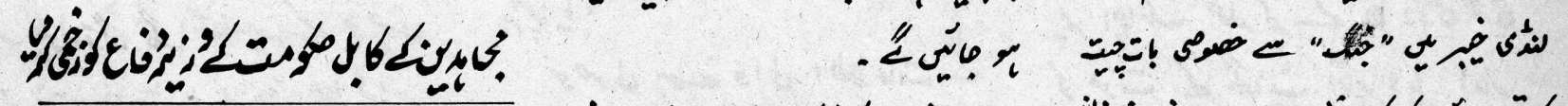
هب 定

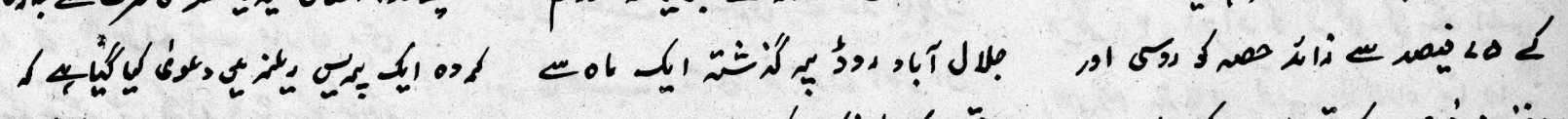

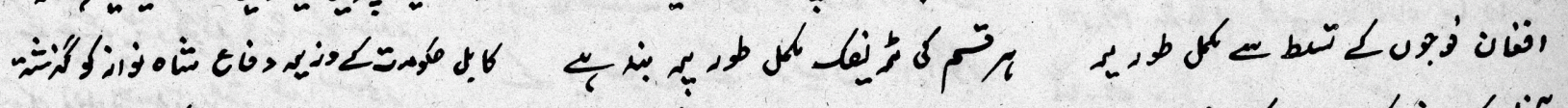

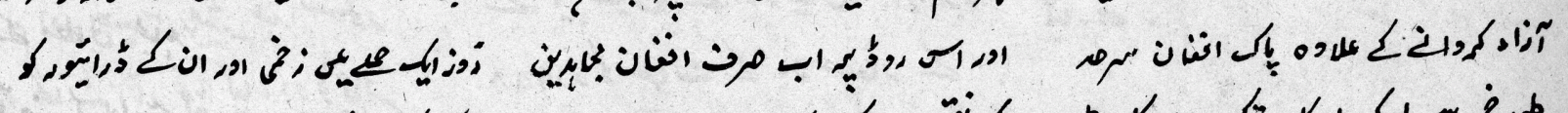

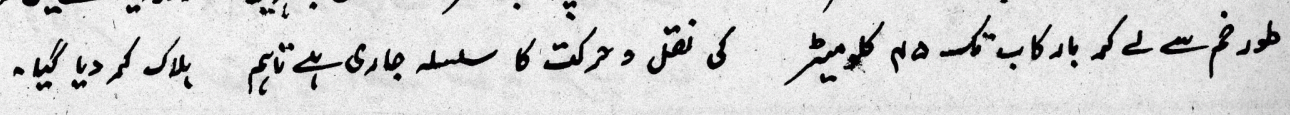


L宊

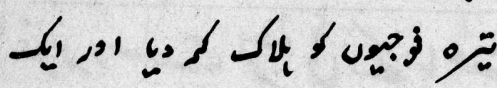

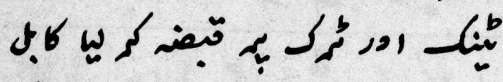
كأك

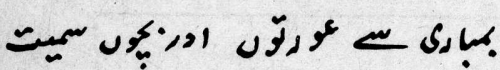

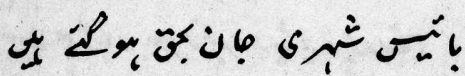

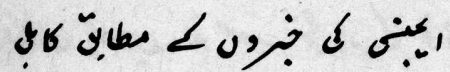

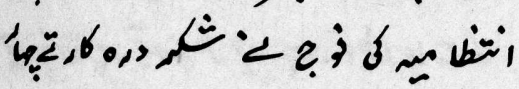

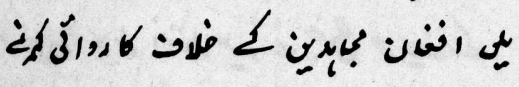

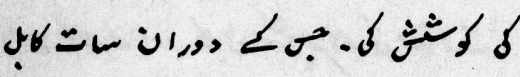
زو

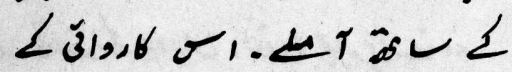
.

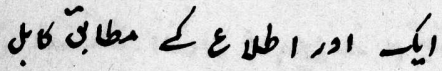
ji إلهإ

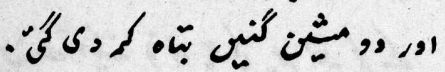

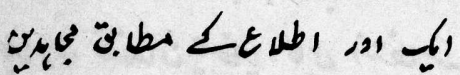

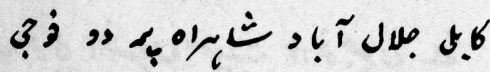

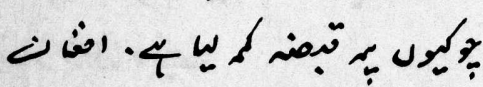
2 .

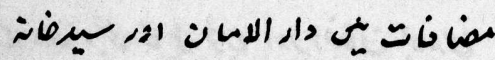

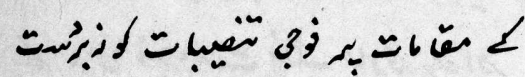

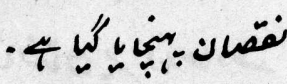

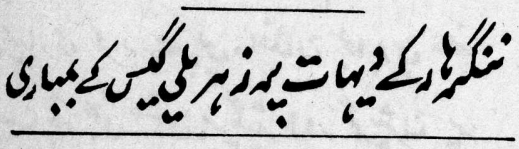

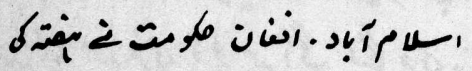

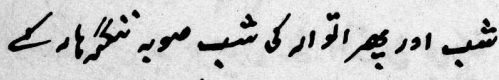

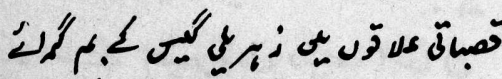

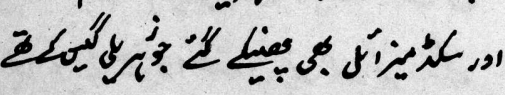

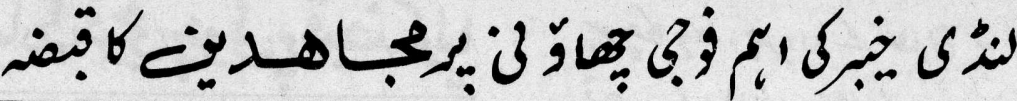

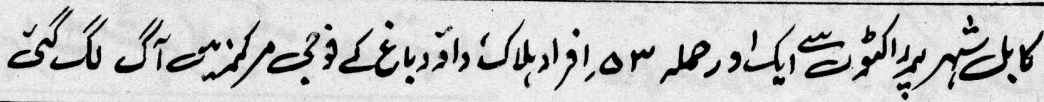

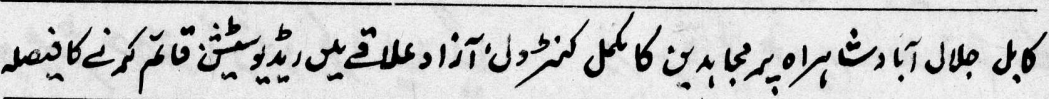

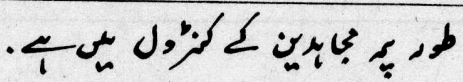

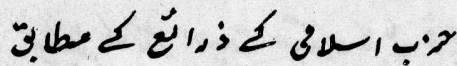
ك'

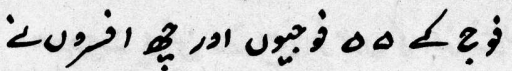

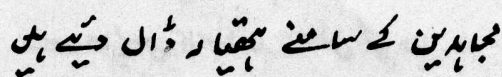

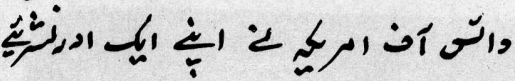

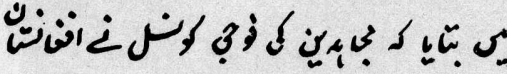

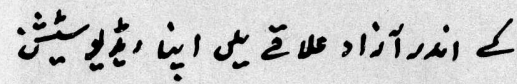
نان

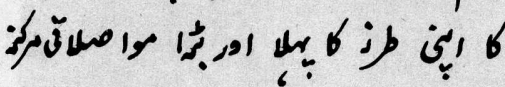

"ז

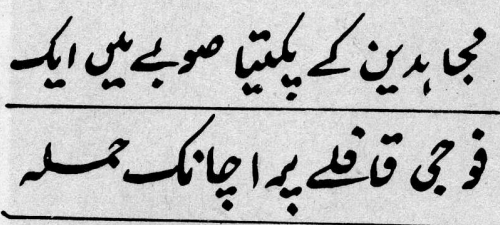

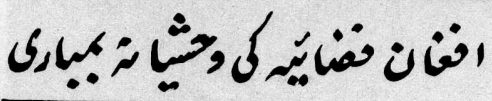

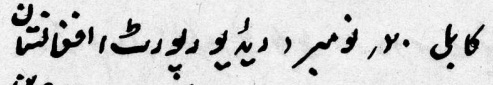
每 غ كان

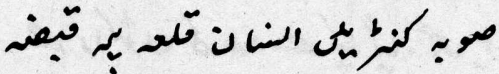
ك

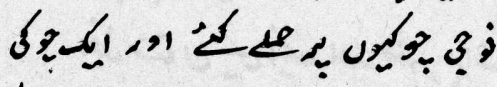
با

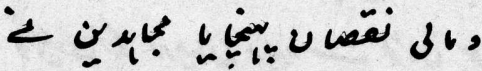

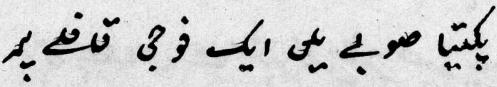

.

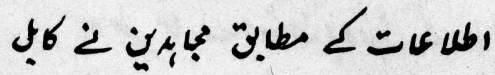

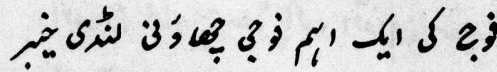

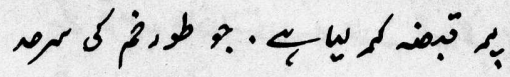
مب

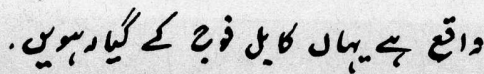

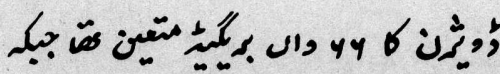

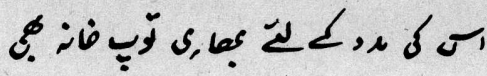
مبه

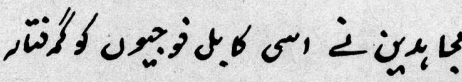

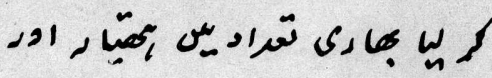

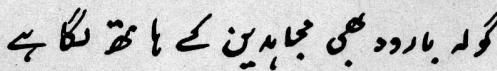

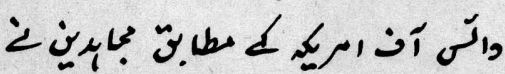

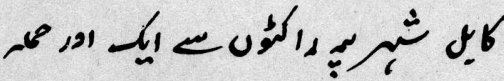

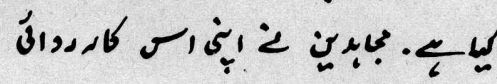

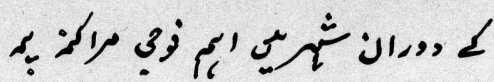
مارج

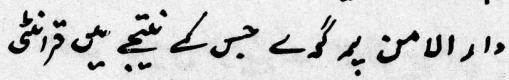

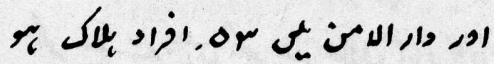

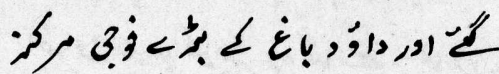

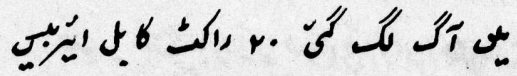

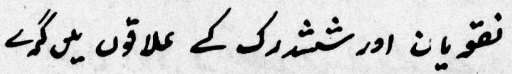

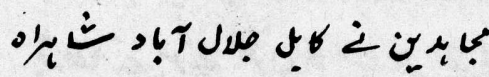

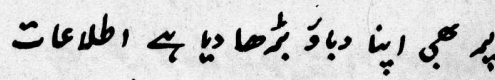

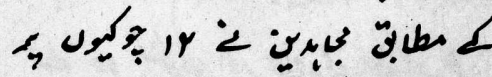
بصن 
$04=$

Tr

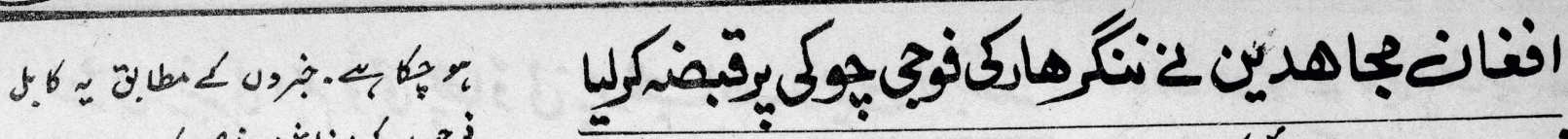
म

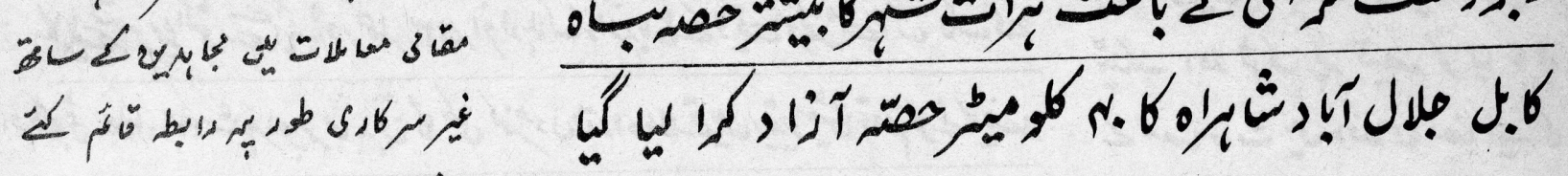
.

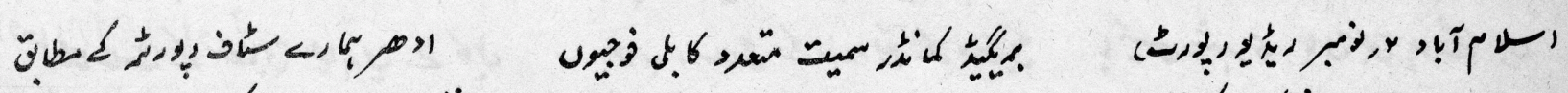

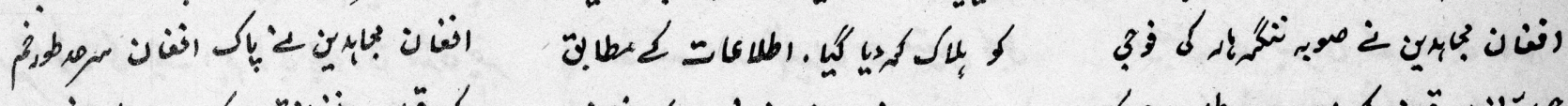

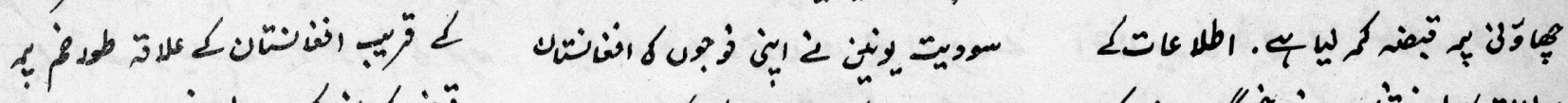

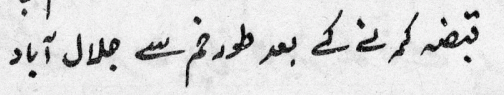

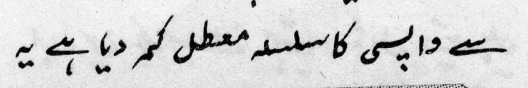

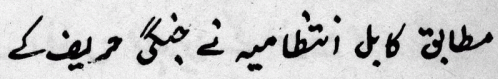
الم ص.

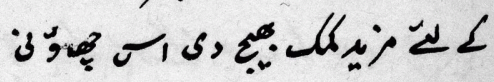

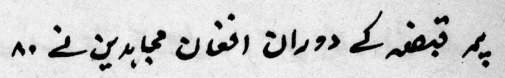

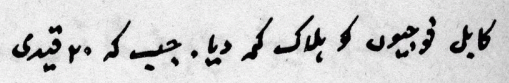

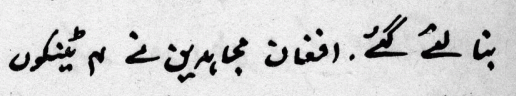

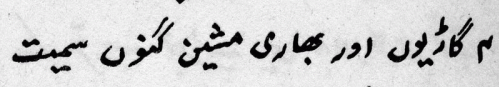

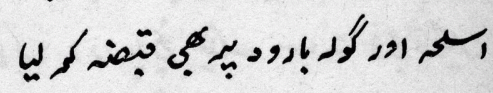

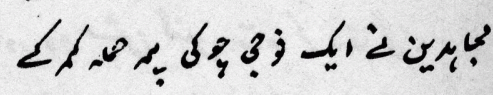

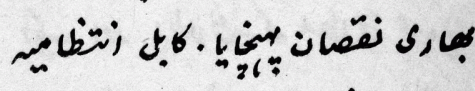

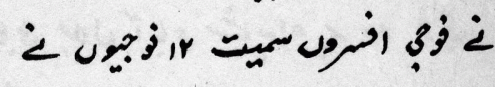

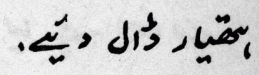

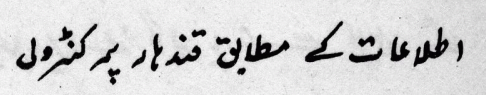

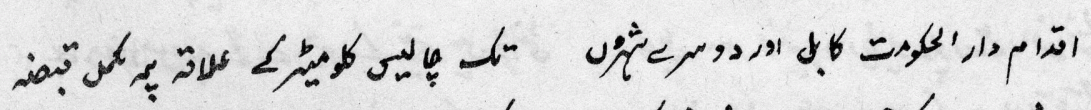
定

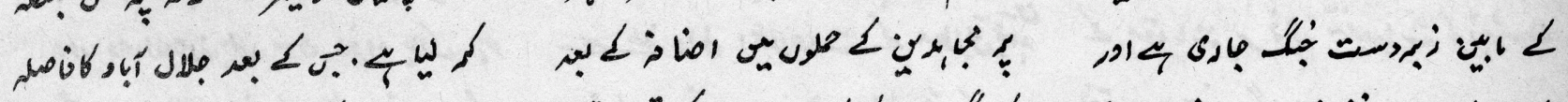

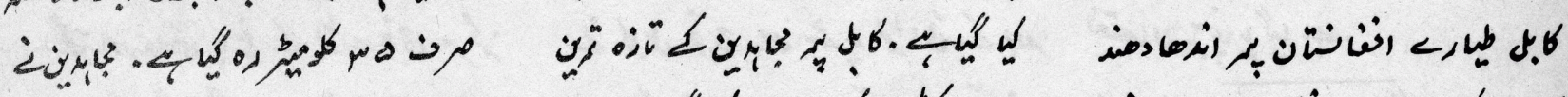

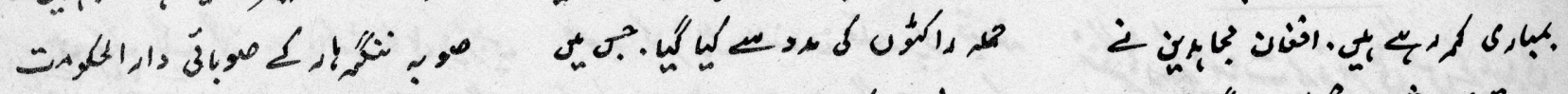

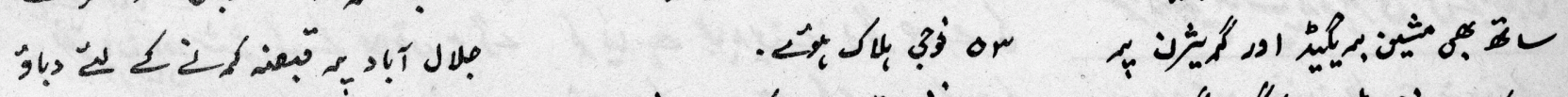

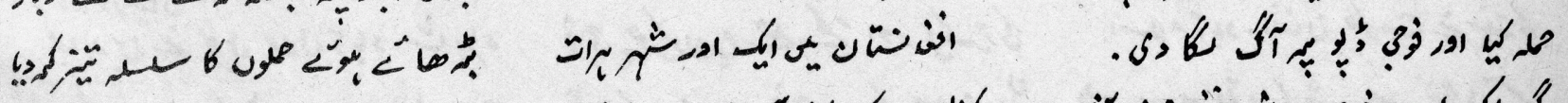

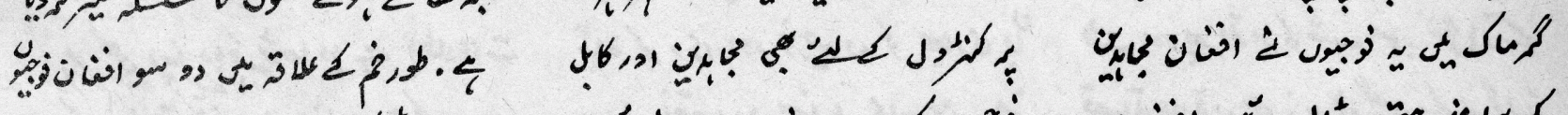

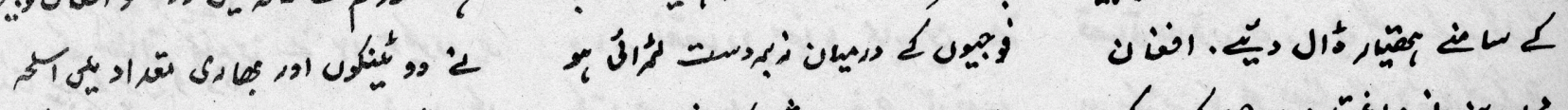

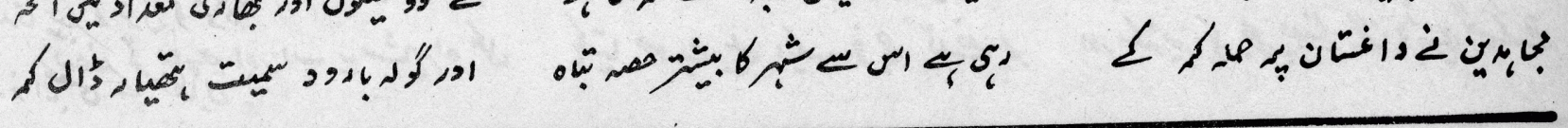


Ix

Qvi

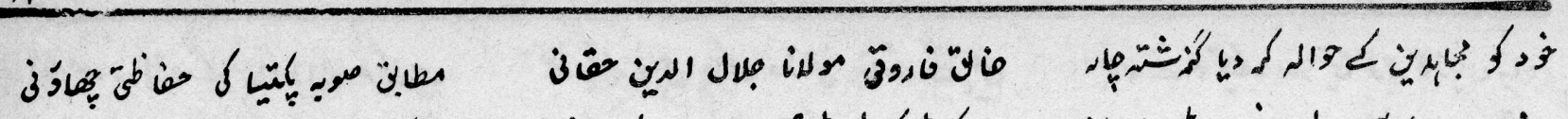

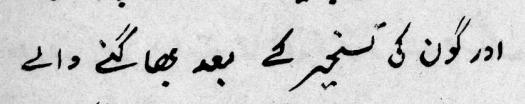
اوركن ن

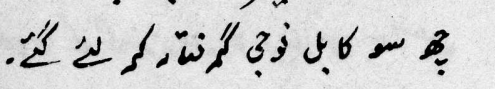

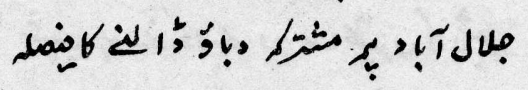

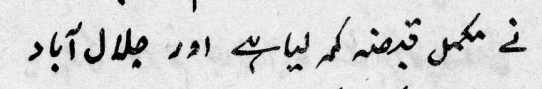

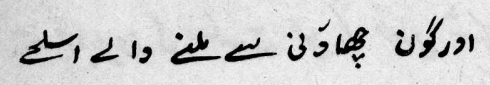
بك

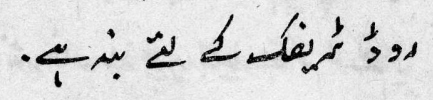

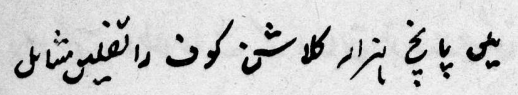

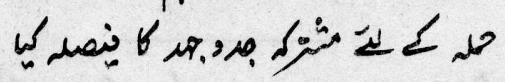

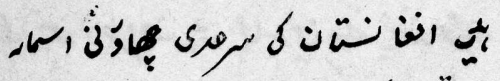
$.4 \%$

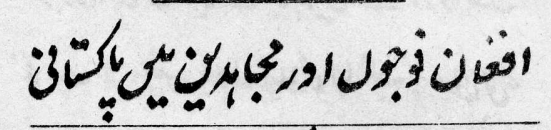

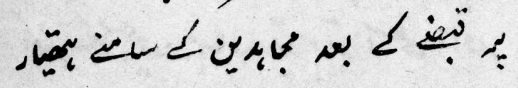

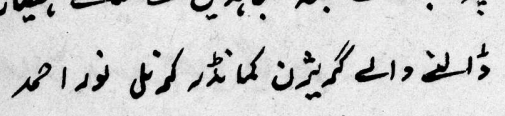

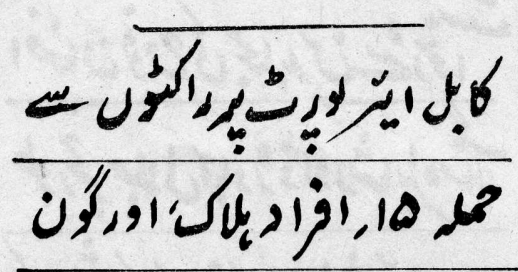

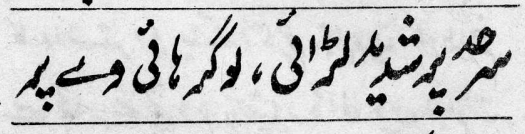

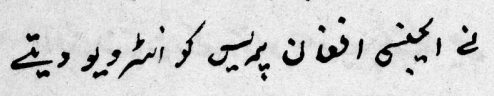

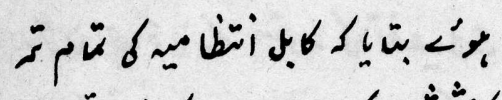

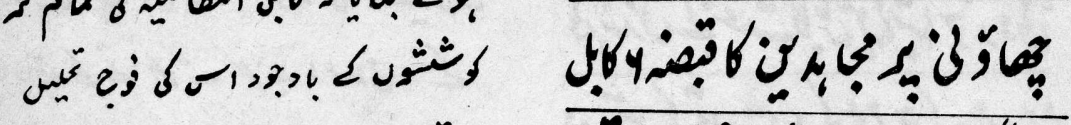

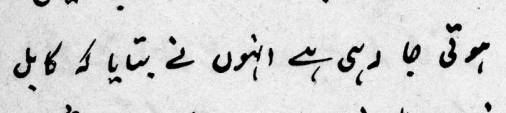
ز

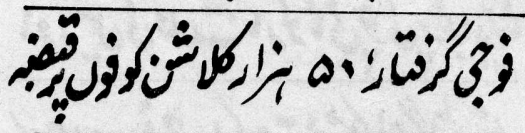

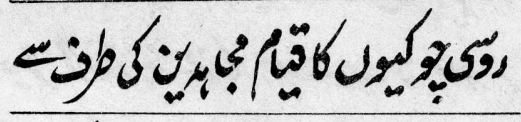

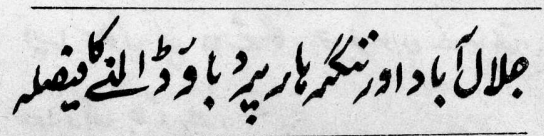

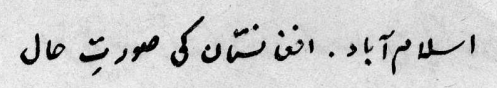

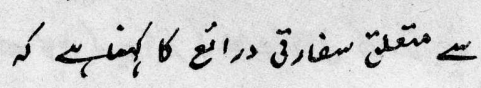

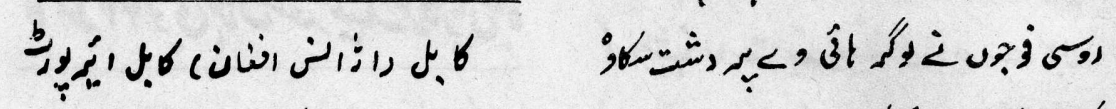

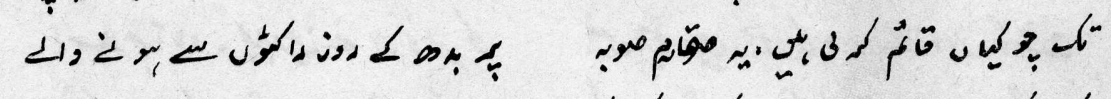

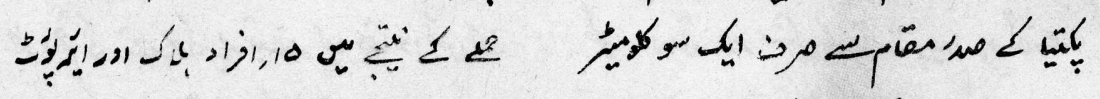

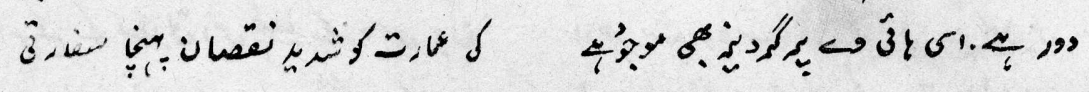

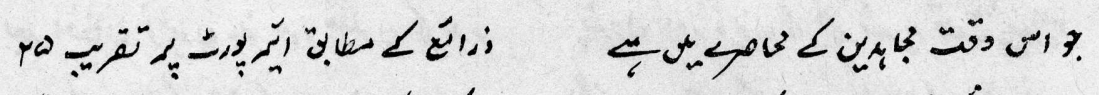

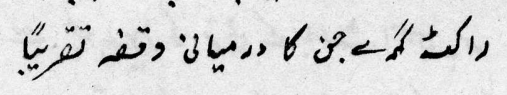

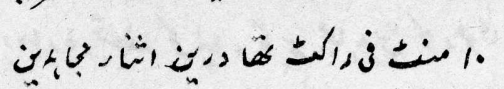

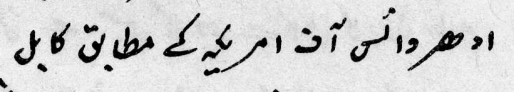
落

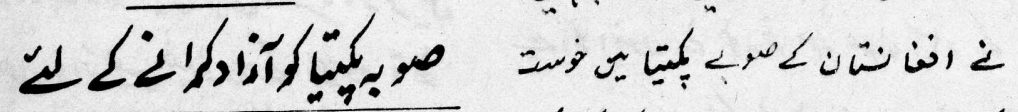

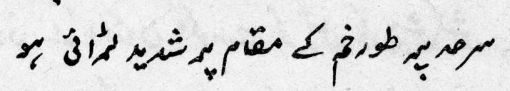
م

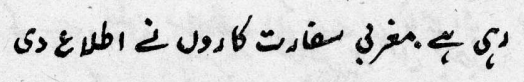

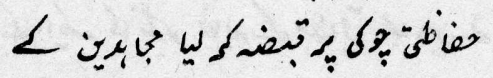

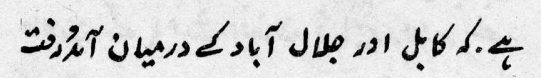

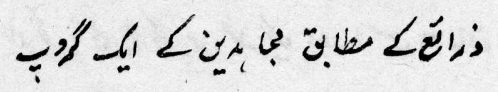

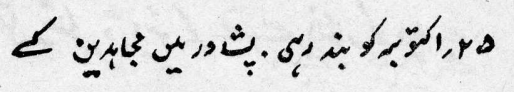

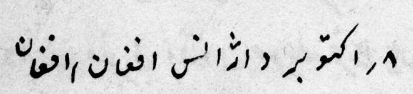

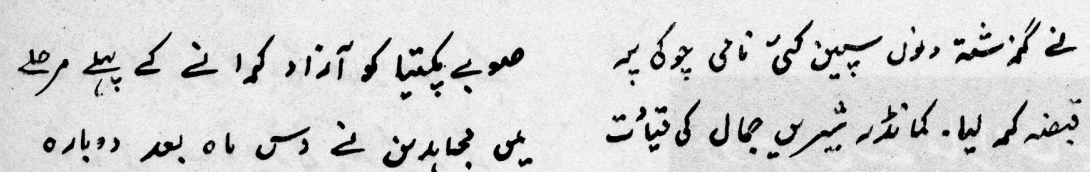

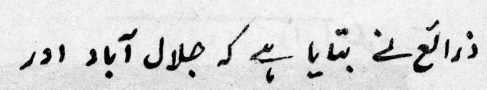

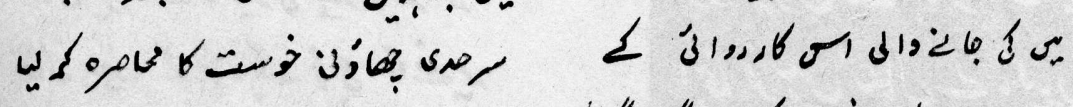
- 4 -

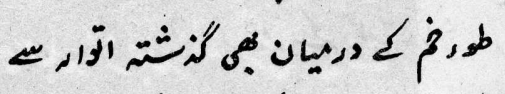

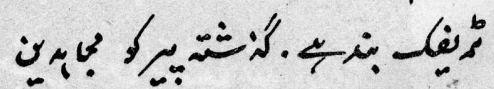
Luجن ن

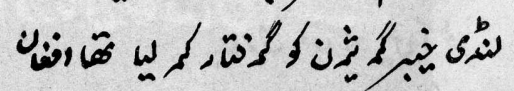

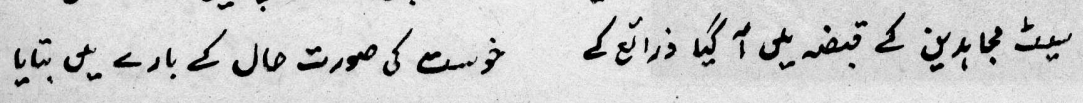

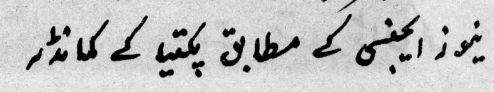


en

TN

乎 -

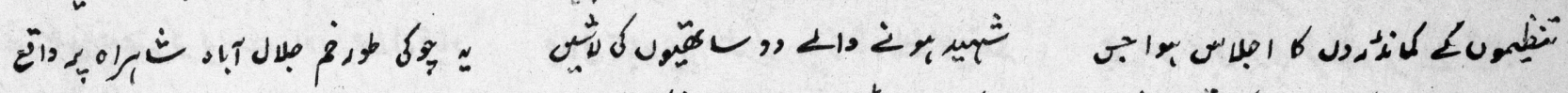

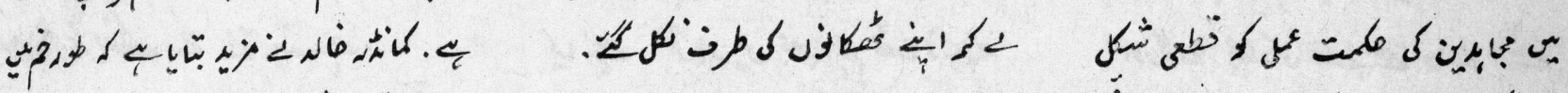
ت

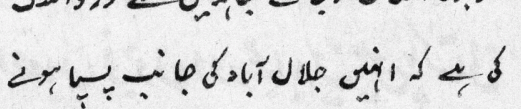

ن

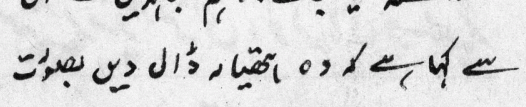

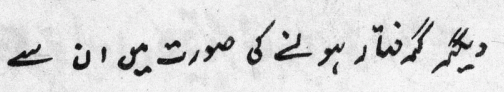

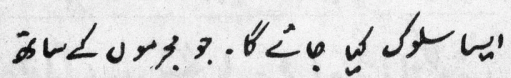

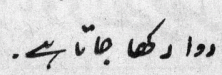

مأ

离这国

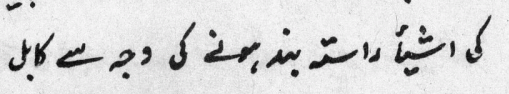

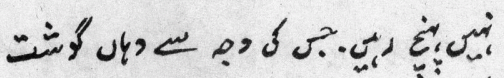

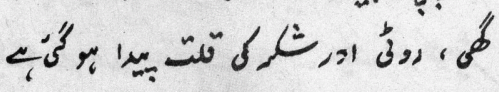

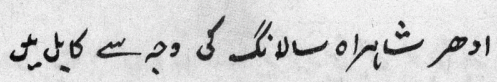

ث:

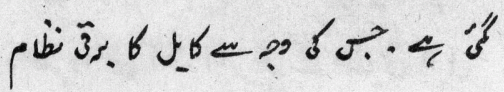

كله

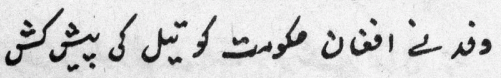

نे

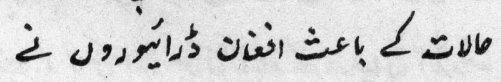

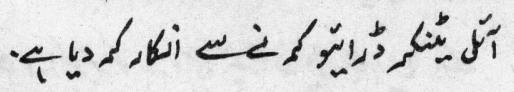

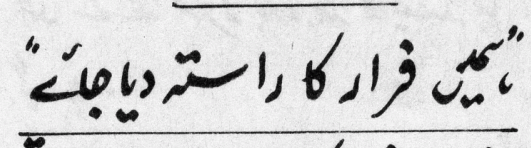

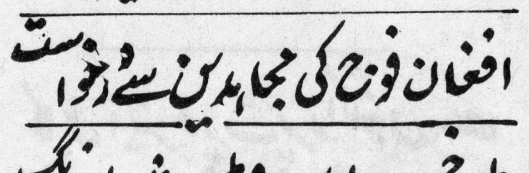

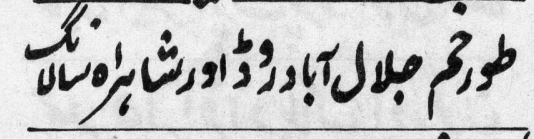

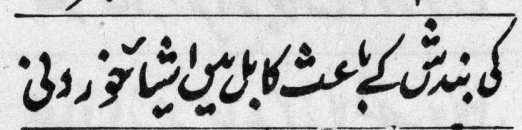

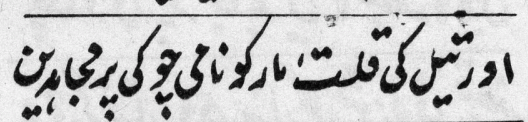

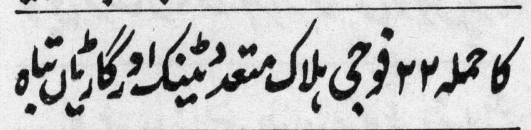

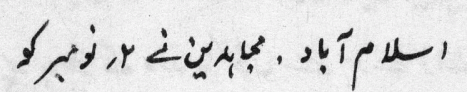

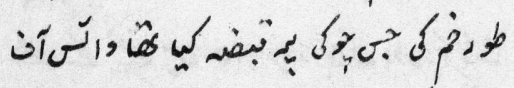

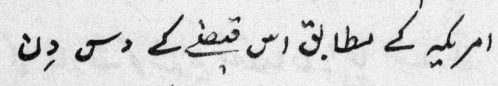

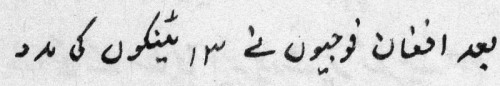

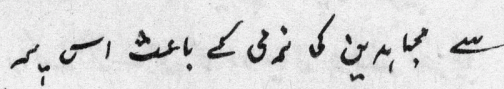

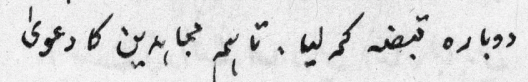

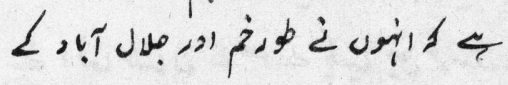

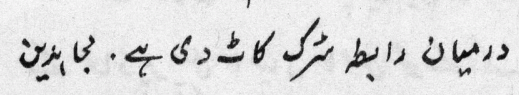

20 2

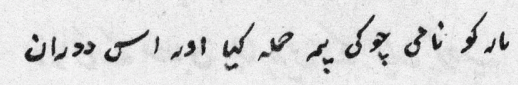

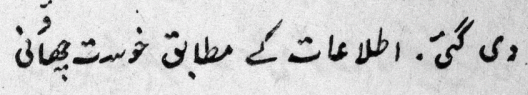

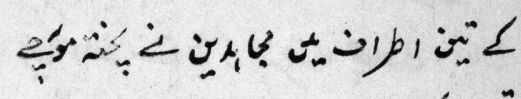

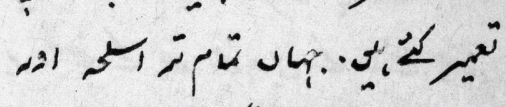

.

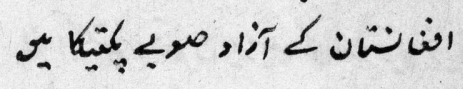

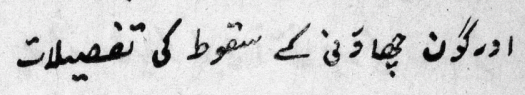

L

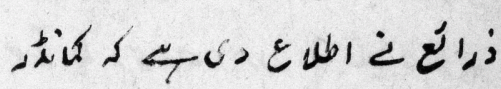

ذران

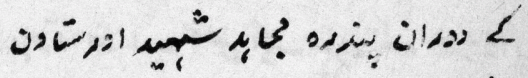

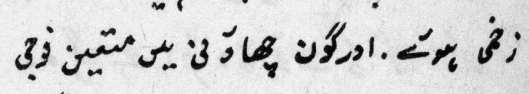

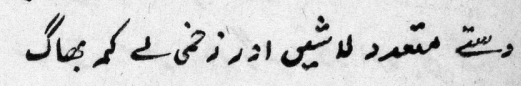

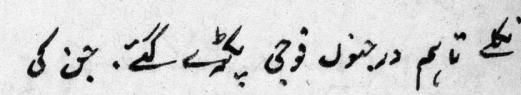

تصار نسيَ بَّة

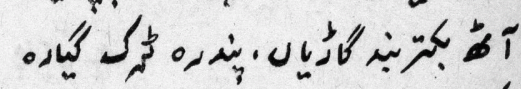

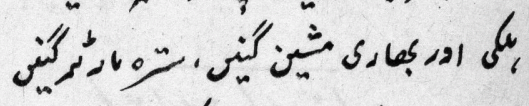

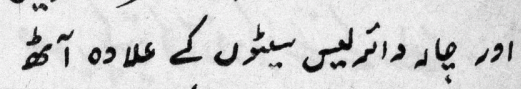

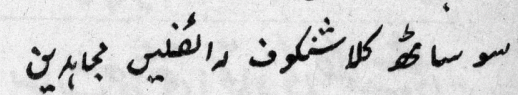

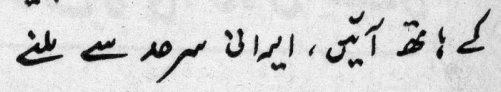

10

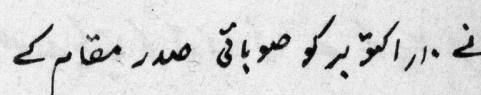

نا

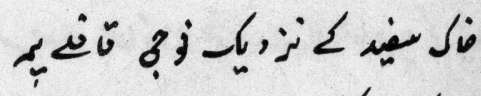

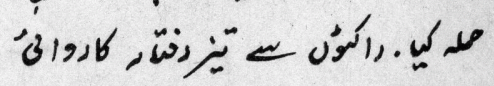

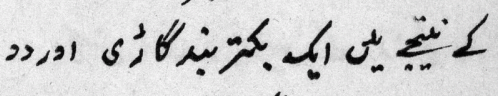

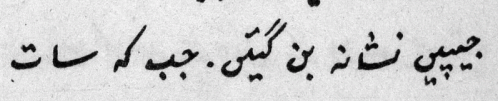




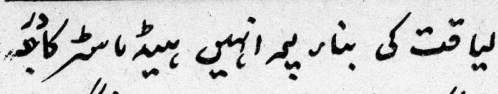

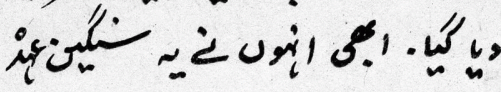

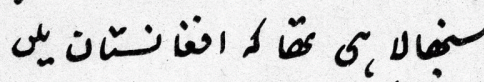

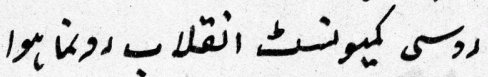

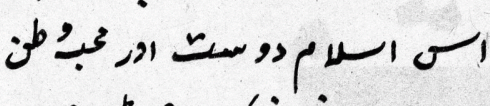

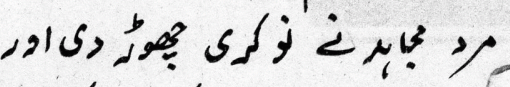
政

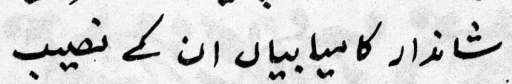
لئه 小

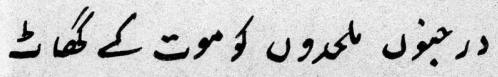

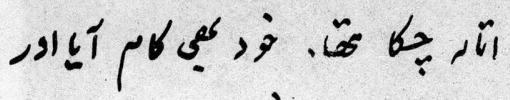

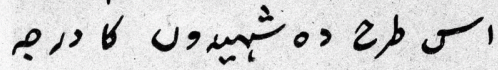

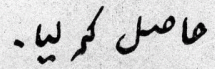

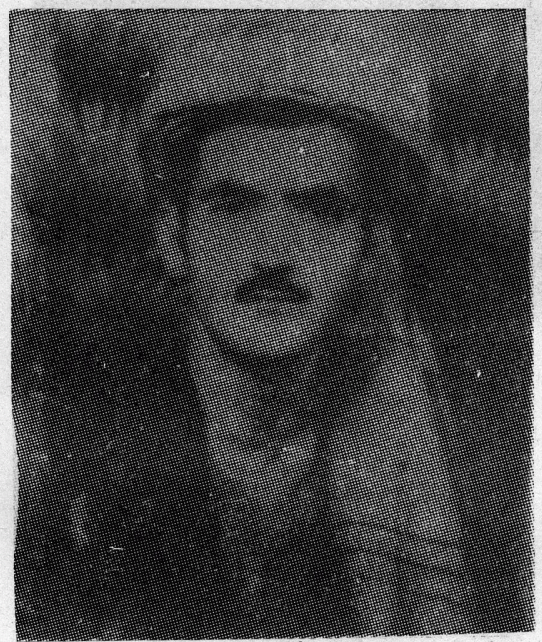

"ن

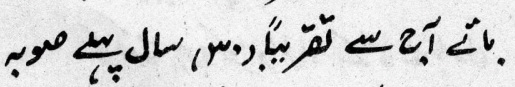

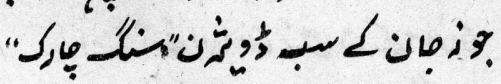
ن نه

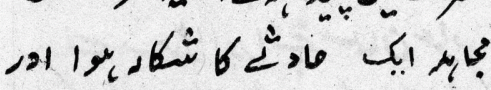
$\angle$ व

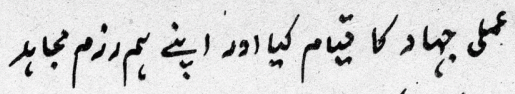

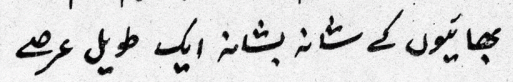

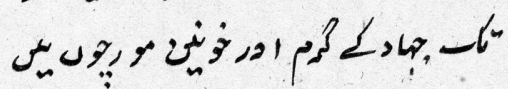

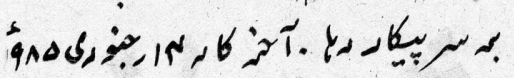

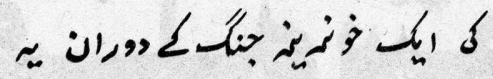

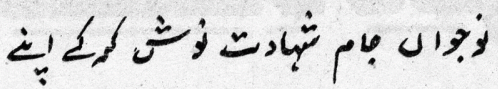

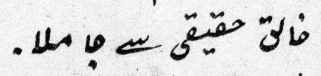

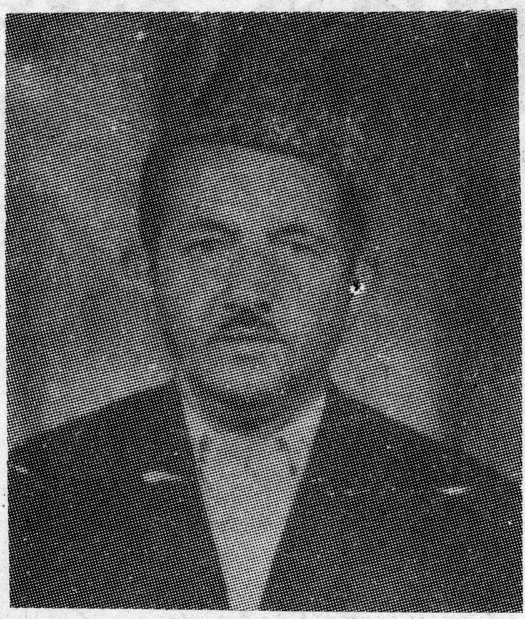

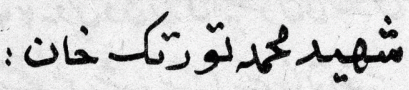

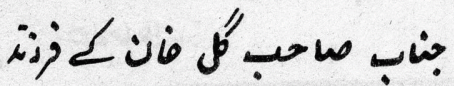
بيّ人 政

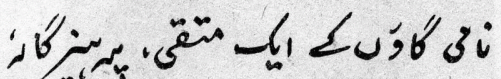

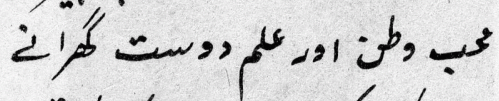

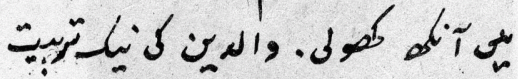

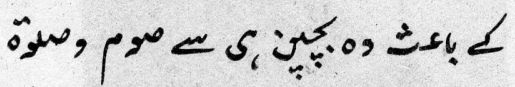

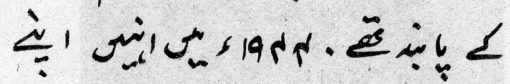
舟

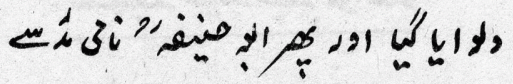
(2).

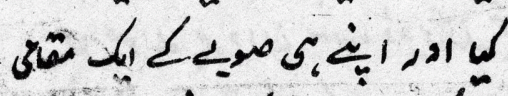

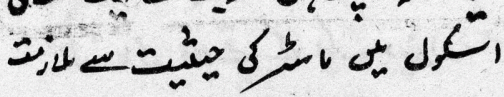

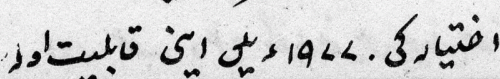

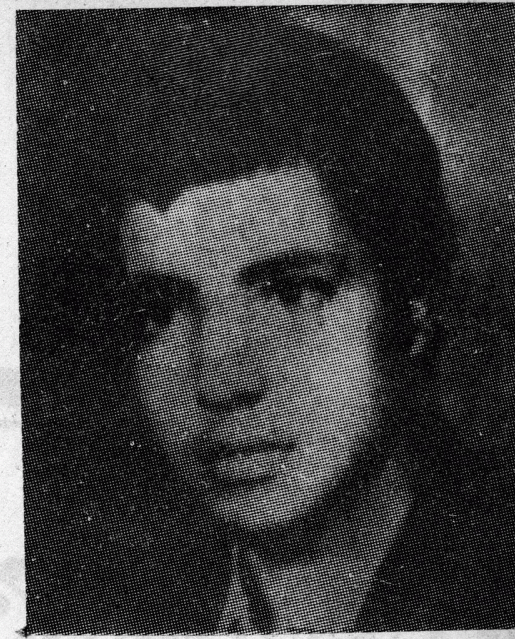

\section{شهيدانبنيّرعمدانور:}

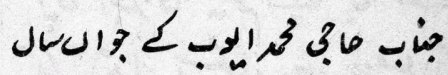
1941 ट ट

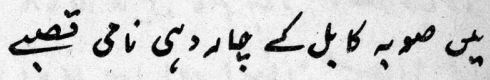
كايكس دينار، وطن دوست اور

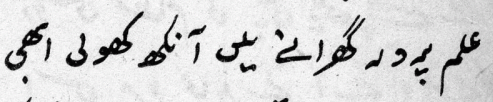

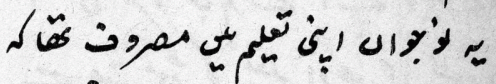

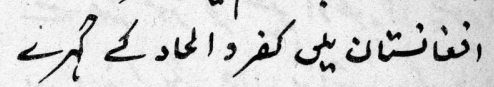

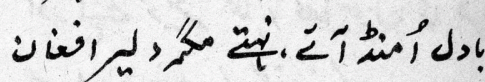
多

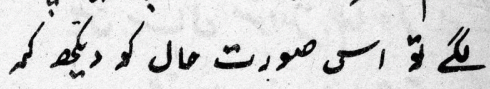

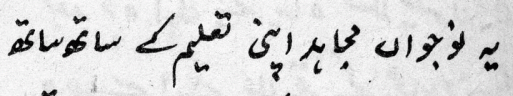

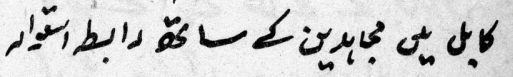

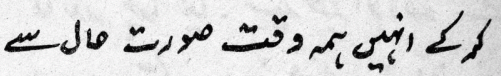

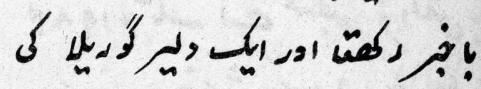

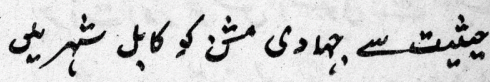
ابكام ويتي ها.

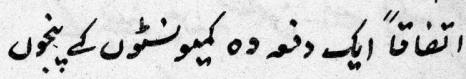
لئ

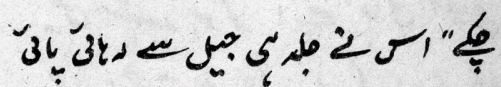

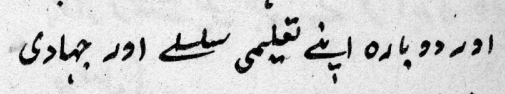

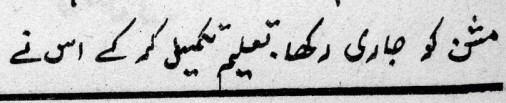




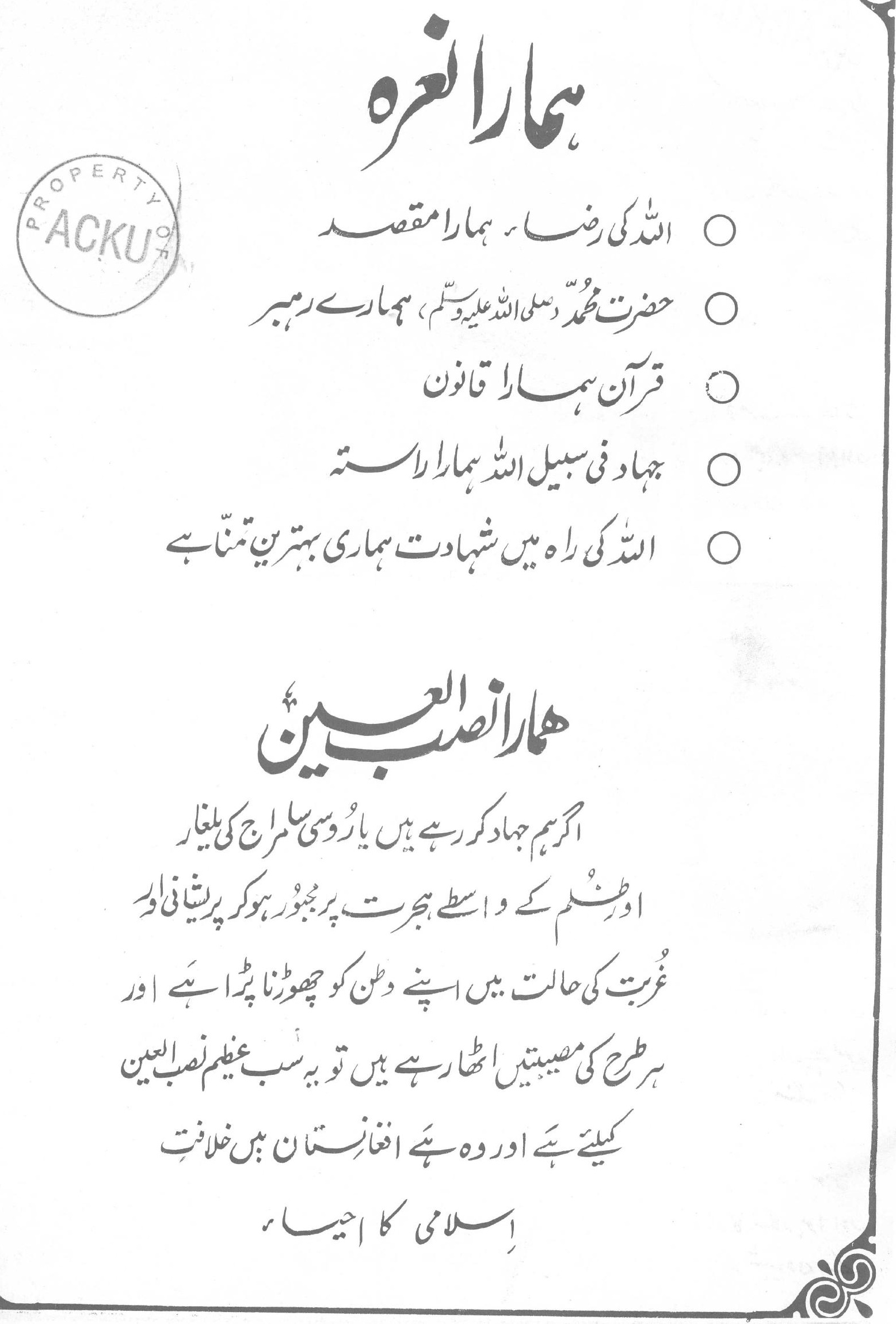


- $\left.{ }^{\circ} A C K U^{\circ}\right)$

min

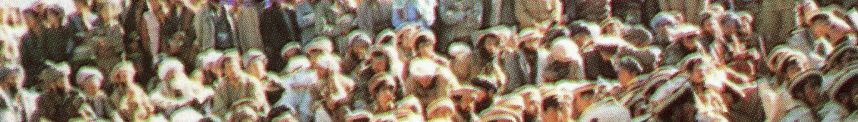

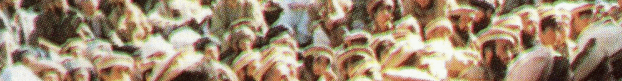

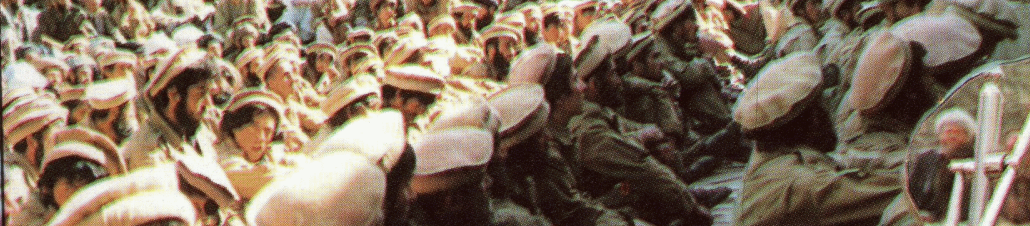

$15-3,1-20$

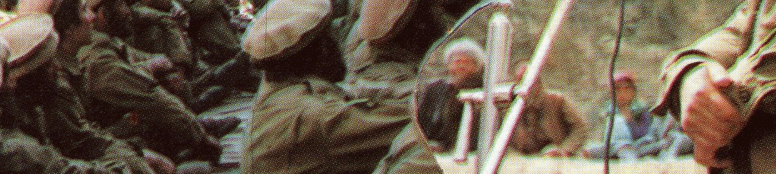

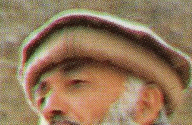

r.

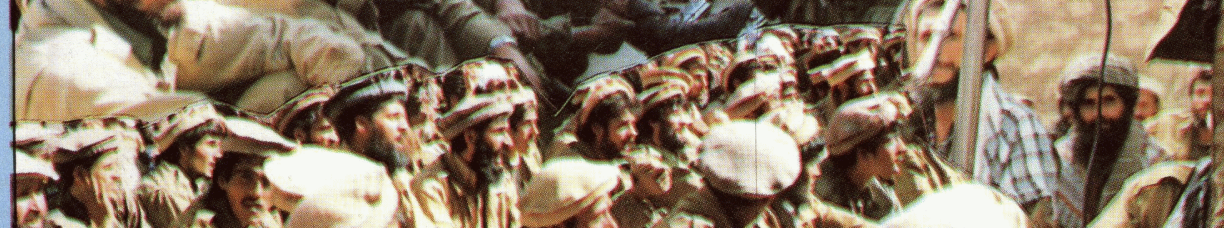

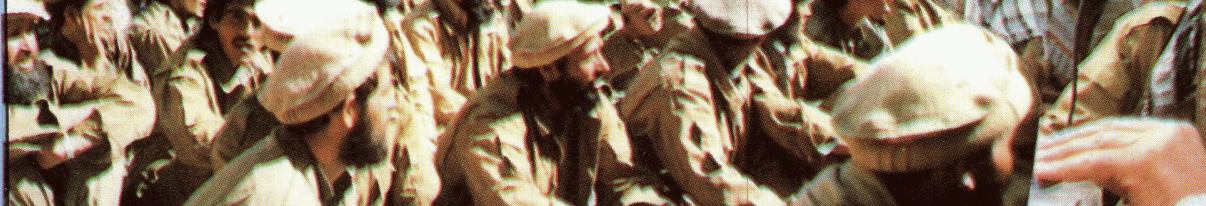

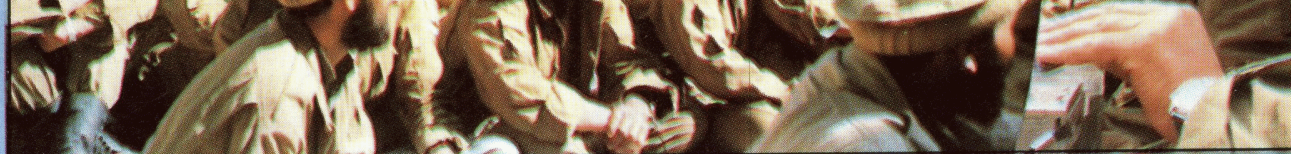

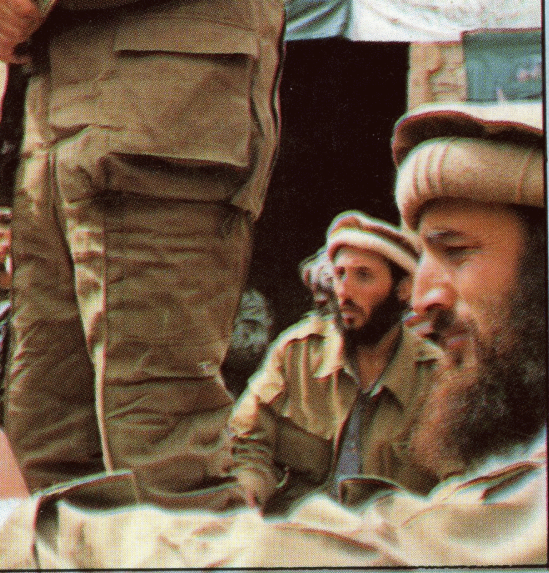

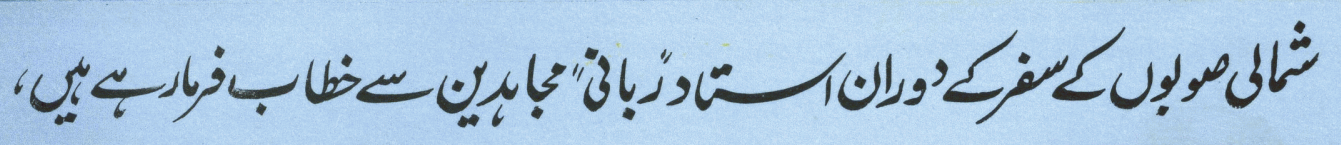

$8 x^{3}+9$ and 131 a $10(0)$

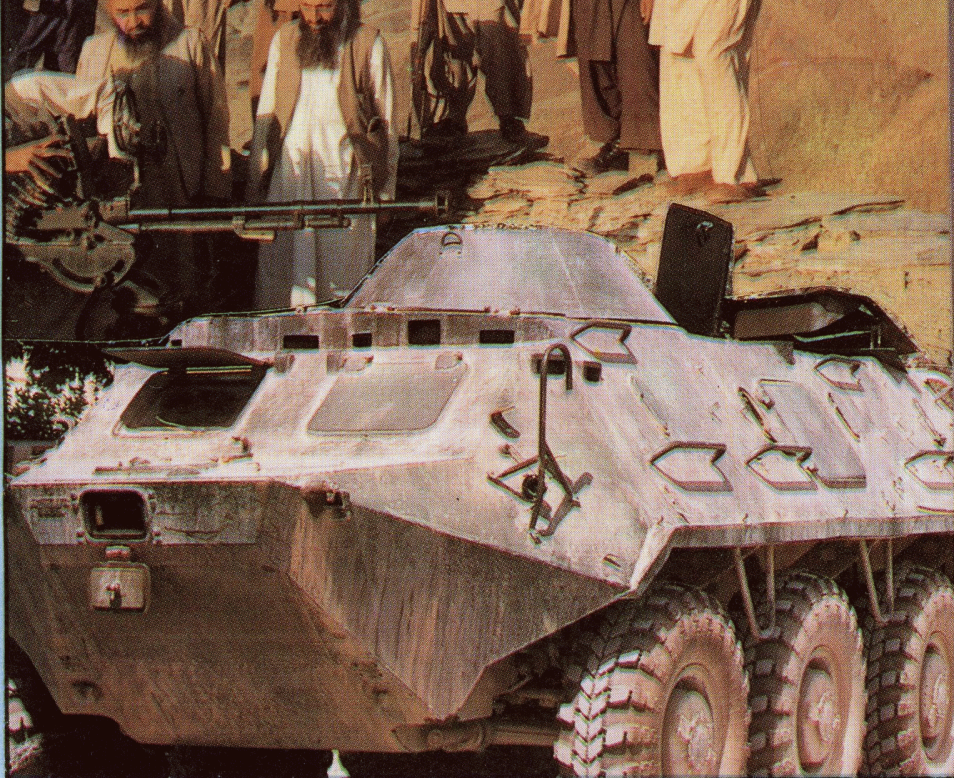

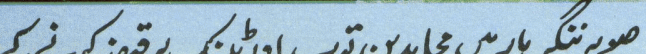

